\title{
Hydrogeology of the Mogollon Highlands, Central Arizona
}

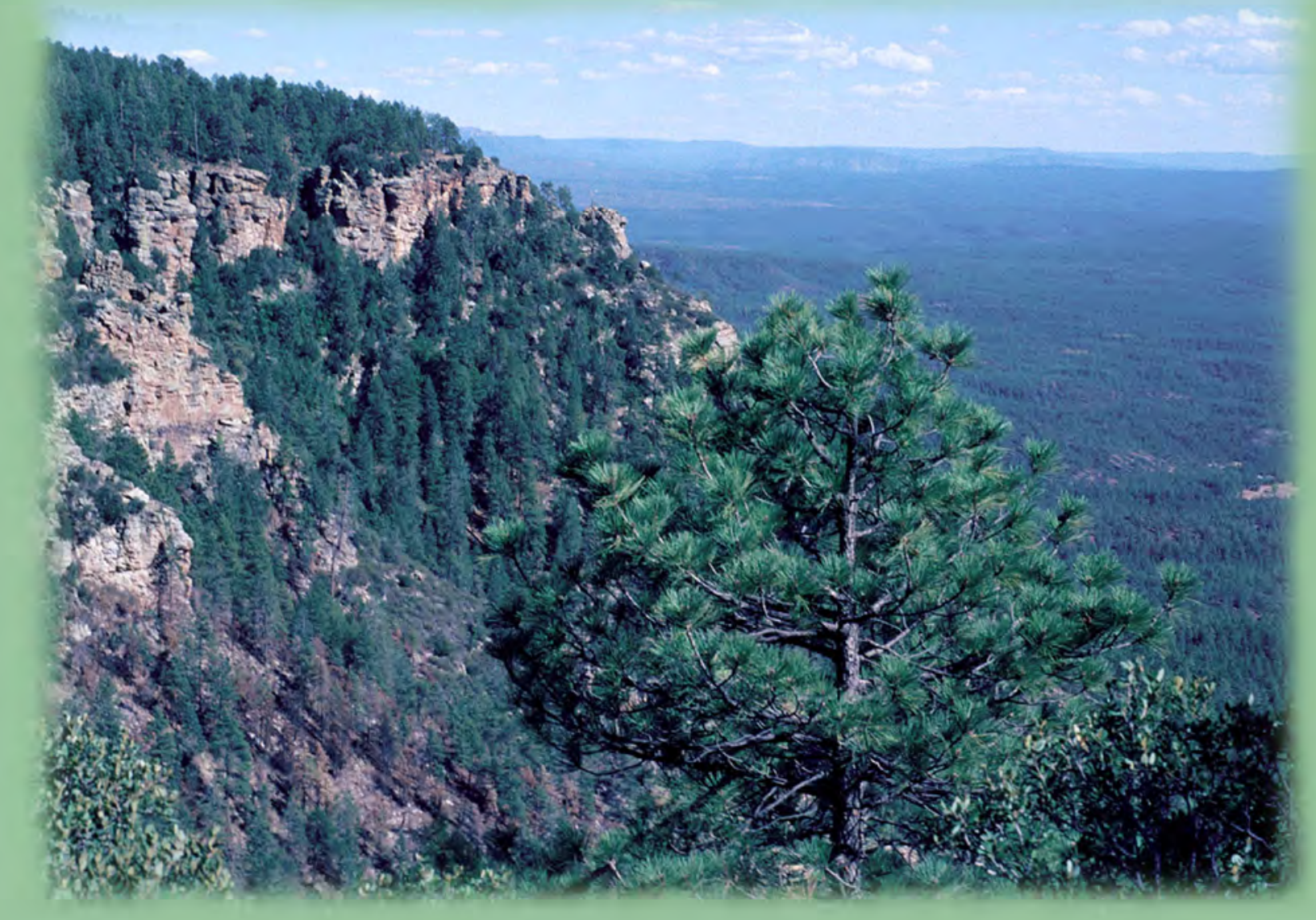

Scientific Investigations Report 2004-5294

U.S. Department of the Interior

U.S. Geological Survey

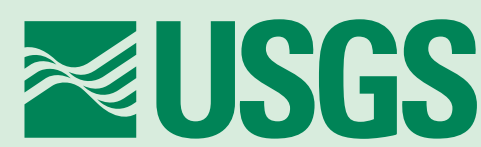


This page left blank intentionally. 


\section{Hydrogeology of the Mogollon Highlands, Central Arizona}

By John T.C. Parker, William C. Steinkampf, and Marilyn E. Flynn

Prepared in cooperation with the

ARIZONA DEPARTMENT OF WATER RESOURCES

Scientific Investigations Report 2004-5294 


\title{
U.S. Department of the Interior Gale A. Norton, Secretary
}

\author{
U.S. Geological Survey \\ Charles G. Groat, Director
}

\section{U.S. Geological Survey, Reston, Virginia: 2005}

For sale by U.S. Geological Survey, Information Services

Box 25286, Denver Federal Center

Denver, CO 80225-0286

Prepared by the Arizona Water Science Center, Tucson.

For more information about the USGS and its products:

Telephone: 1-888-ASK-USGS

World Wide Web: http://www.usgs.gov/

Any use of trade, product, or firm names in this publication is for descriptive purposes only and does not imply endorsement by the U.S. Government.

Although this report is in the public domain, permission must be secured from the individual copyright owners to reproduce any copyrighted materials contained within this report. 


\section{Contents}

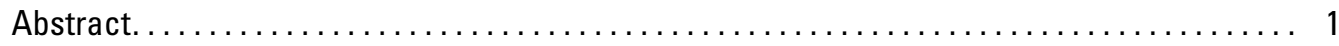

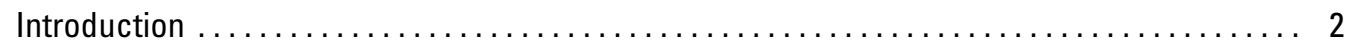

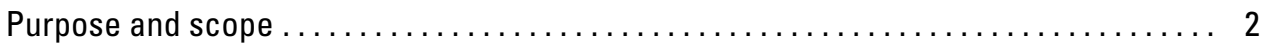

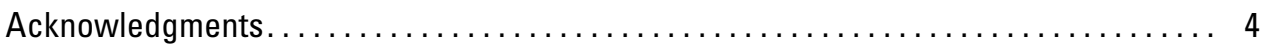

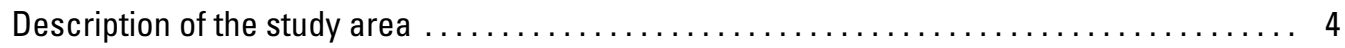

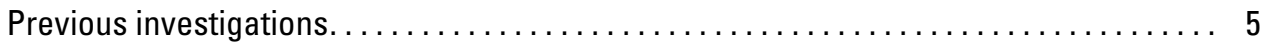

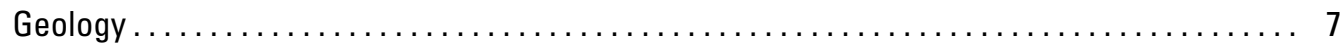

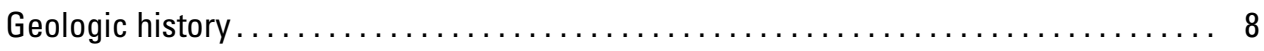

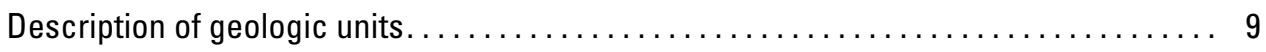

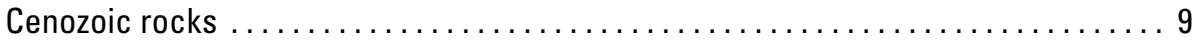

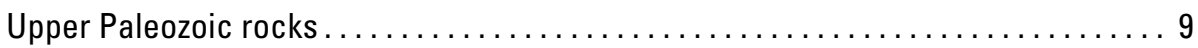

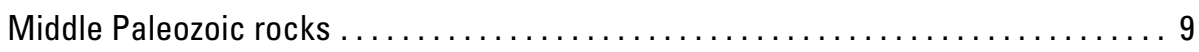

Lower Paleozoic rocks.................................. 10

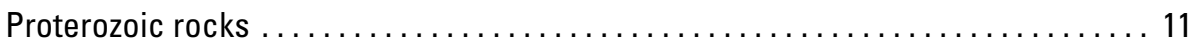

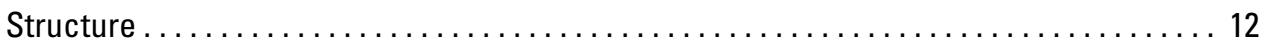

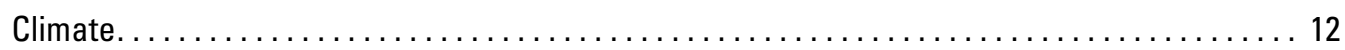

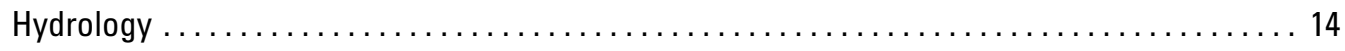

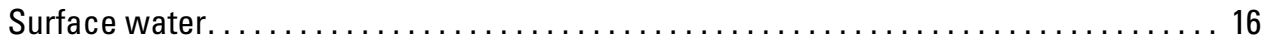

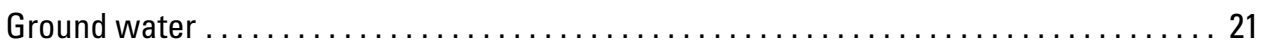

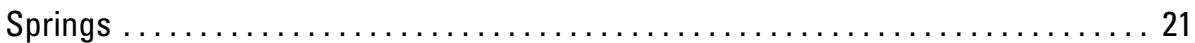

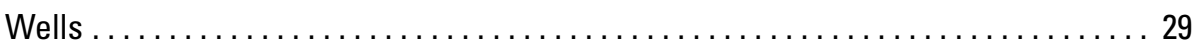

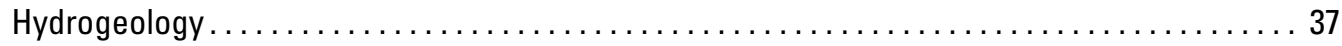

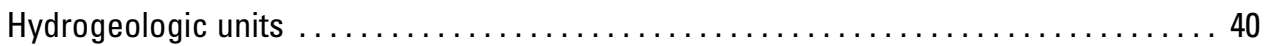

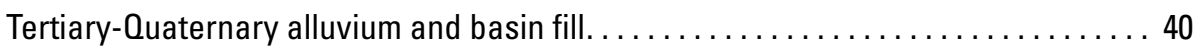

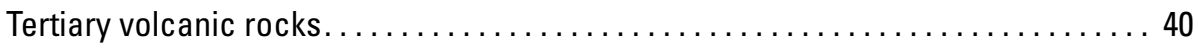

Upper Paleozoic rocks .................................... 40

Middle Paleozoic rocks .................................... 40

Lower Paleozoic rocks.................................... 41

Proterozoic igneous and metamorphic rocks $\ldots \ldots \ldots \ldots \ldots \ldots \ldots \ldots \ldots \ldots \ldots$

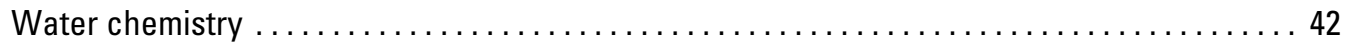

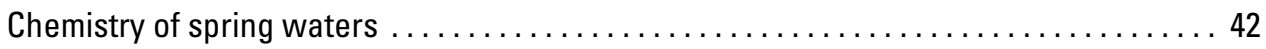

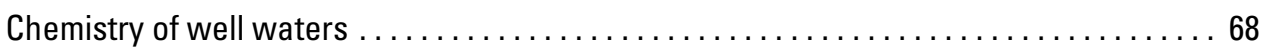

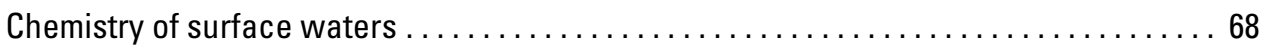

Hydrogeologic framework and conceptual model $\ldots \ldots \ldots \ldots \ldots \ldots \ldots \ldots \ldots \ldots, \ldots 6 \ldots \ldots$

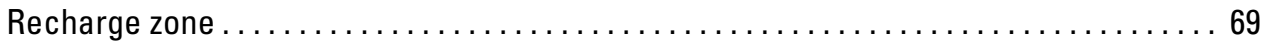

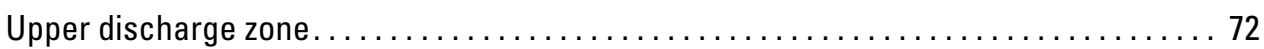

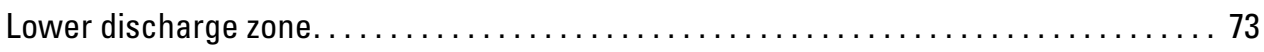

Local water-bearing zones on the Mogollon Rim....................... 74

Local water-bearing zones below the Mogollon Rim ..................... 75

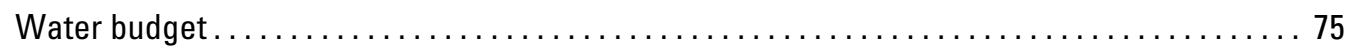

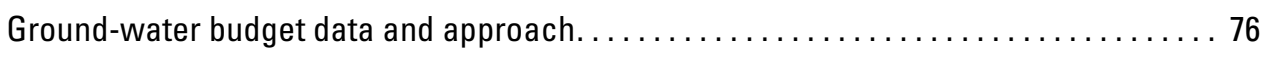

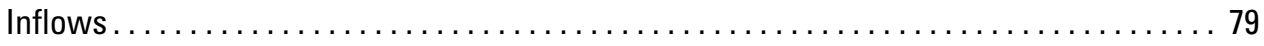

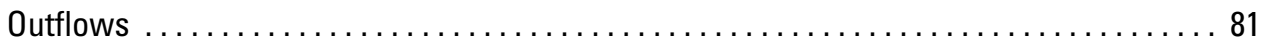

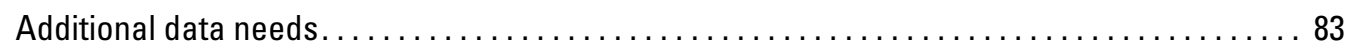

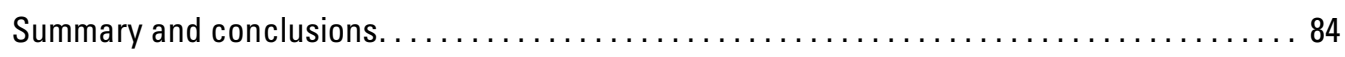

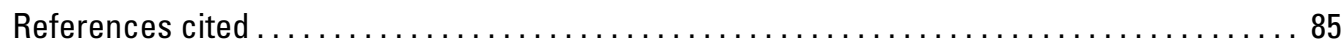




\section{Figures}

1. Map showing study area and U.S. Geological Survey streamflowgaging stations in the Mogollon Highlands, central Arizona ...................................... 3

2. Map showing U.S. Geological Survey Rural Watershed Initiative study areas

. Graph showing annual ground-water withdrawals by the town of Payson, Arizona

4. Map showing geology and geologic structure of the Mogollon Highlands, central Arizona.

Map showing average annual precipitation and locations of active weather stations in the Mogollon Highlands, central Arizona

Graphs showing:

6. Seasonal distribution of precipitation for selected sites in the Mogollon Highlands, central Arizona.

7. A. Normalized annual average precipitation for the Mogollon Highlands, central Arizona........................................................... 15

B. Normalized annual average temperature for Payson, Arizona ...................... 15

8. Seasonal distribution of annual peak discharges of selected streams in the Mogollon Highlands, central Arizona

9. Seasonal distribution of discharge of selected streams in the Mogollon Highlands, central Arizona.

10. Daily discharge of Tonto Creek above Gun Creek showing typical range of daily discharge for Mogollon Highlands streams, central Arizona

11. Lowest flows on selected perennial streams in the Mogollon Highlands, central Arizona .

12. Flow duration curve for selected streams in the Mogollon Highlands, central Arizona

13. Runoff and base-flow components of selected streams in the

Mogollon Highlands, central Arizona

14. Map showing distribution of springs and wells in the Mogollon

Highlands, central Arizona.

15. Map showing geology, geologic structure, and locations of springs for which discharge records are available, Mogollon Highlands, central Arizona.

16-17. Graphs showing:

16. Discharge of springs for which repeated measurements are available, Mogollon Highlands, central Arizona:

A. Spring discharge measured at fish hatcheries once a month 28

B. Discharge measured once daily in Pine Creek below Tonto Natural Bridge Spring.

C. Discharge from intermittent current-meter measurements in

Fossil Creek above and below springs

17. A. Percentage of total springs by range of discharge ....................................... 29

B. Percentage of total spring discharge by range of discharge, Mogollon Highlands, central Arizona

18. Map showing selected wells for which water-level data are available, Mogollon Highlands, central Arizona.

19. Graphs showing time series of water depths in selected wells, Mogollon Highlands, Arizona

20. Map showing springs for which chemical data are available and sampling sites for isotope analysis of spring water, Mogollon Highlands, central Arizona. 


\section{Figures-Continued}

21. Graphs showing relative compositions of water from springs in the Mogollon Highlands, central Arizona.

22. Graphs showing chemical composition of spring waters within different drainages, Mogollon Highlands, central Arizona.
A. Specific conductance. 49
B. Calcium, magnesium, and sodium ……......................................................... 49
C. Chloride and sulfate .................................................................................. 49

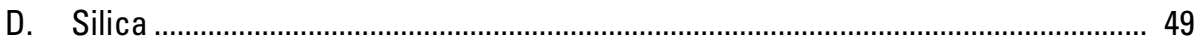

23. Graph showing isotope values for water from springs in the Mogollon Highlands, central Arizona......................................................................... 51

24. Map showing wells for which chemical data are available, Mogollon Highlands, central Arizona.

25. Graphs showing chemical composition of waters from wells in various locations, Mogollon Highlands, central Arizona.
A. Specific conductance. 62

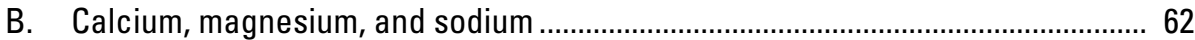
C. Chloride and sulfate .................................................................................. 62
D. Silica ........................................................................................................... 62

26. Map showing potentiometric surfaces of the $C$ aquifer, limestone aquifer, and alluvial aquifer in the lower Tonto Creek Basin, Mogollon Highlands, Arizona

27. Schematic diagram of the ground-water system in the Mogollon

Highlands, central Arizona 


\section{Tables}

1. Summary precipitation statistics for Mogollon Highlands, Arizona, weather stations by decade.

2. Streamflow-gaging stations in the Mogollon Highlands, central Arizona, referred to in this report.

3. Summary statistics of average daily streamflow values for active streamflow-gaging stations in the Mogollon Highlands, central Arizona..

4. Discharge values for springs in the Mogollon Highlands, central Arizona..

5. Statistical summary of discharge values for monitored springs, Mogollon Highlands, central Arizona

6. Selected wells for which water-level data are available, Mogollon Highlands, central Arizona

7. Physical and chemical properties and chemical composition of spring waters in the Mogollon Highlands, central Arizona

8. Physical and chemical properties and chemical composition of ground water at wells in the Mogollon Highlands, central Arizona

9. Summary statistics of water-chemistry data for Mogollon Highlands streams. 64

10. Oxygen and hydrogen isotope values for Mogollon Highlands springs................... 66

11. Strontium isotope values for spring waters and host rocks..................................... 66

12. Stream-discharge, spring-discharge, and precipitation values used to compute water budget for regional aquifer .

13. Results of regression to extend stream records.

14. Summation of water inflows and outflows for $C$ aquifer and limestone aquifer 


\section{Conversion Factors and Datum}

\begin{tabular}{|c|c|c|}
\hline Multiply & By & To obtain \\
\hline \multicolumn{3}{|c|}{ Length } \\
\hline inch (in.) & 2.54 & centimeter $(\mathrm{cm})$ \\
\hline inch (in.) & 25.4 & millimeter (mm) \\
\hline foot $(\mathrm{ft})$ & 0.3048 & meter $(\mathrm{m})$ \\
\hline mile (mi) & 1.609 & kilometer $(\mathrm{km})$ \\
\hline \multicolumn{3}{|c|}{ Area } \\
\hline acre & 4,047 & square meter $\left(\mathrm{m}^{2}\right)$ \\
\hline acre & 0.004047 & square kilometer $\left(\mathrm{km}^{2}\right)$ \\
\hline square foot $\left(\mathrm{ft}^{2}\right)$ & 0.09290 & square meter $\left(\mathrm{m}^{2}\right)$ \\
\hline square mile $\left(\mathrm{mi}^{2}\right)$ & 2.590 & square kilometer $\left(\mathrm{km}^{2}\right)$ \\
\hline \multicolumn{3}{|c|}{ Volume } \\
\hline gallon (gal) & 3.785 & liter $(\mathrm{L})$ \\
\hline gallon (gal) & 0.003785 & cubic meter $\left(\mathrm{m}^{3}\right)$ \\
\hline cubic foot $\left(\mathrm{ft}^{3}\right)$ & 0.02832 & cubic meter $\left(\mathrm{m}^{3}\right)$ \\
\hline acre-foot (acre-ft) & 1,233 & cubic meter $\left(\mathrm{m}^{3}\right)$ \\
\hline \multicolumn{3}{|c|}{ Flow rate } \\
\hline acre-foot per year (acre-ft/yr) & 1,233 & cubic meter per year $\left(\mathrm{m}^{3} / \mathrm{yr}\right)$ \\
\hline cubic foot per second $\left(\mathrm{ft}^{3} / \mathrm{s}\right)$ & 0.02832 & cubic meter per second $\left(\mathrm{m}^{3} / \mathrm{s}\right)$ \\
\hline gallon per minute (gal/min) & 0.06309 & liter per second (L/s) \\
\hline \multicolumn{3}{|c|}{ Specific capacity } \\
\hline gallon per minute per foot & & \\
\hline$[(\mathrm{gal} / \mathrm{min}) / \mathrm{ft})]$ & 0.2070 & liter per second per meter $[(\mathrm{L} / \mathrm{s} / \mathrm{m}]$ \\
\hline \multicolumn{3}{|c|}{ Transmissivity* } \\
\hline foot squared per day $\left(\mathrm{ft}^{2} / \mathrm{d}\right)$ & 0.09290 & meter squared per day $\left(\mathrm{m}^{2} / \mathrm{d}\right)$ \\
\hline
\end{tabular}

Temperature in degrees Fahrenheit $\left({ }^{\circ} \mathrm{F}\right)$ may be converted to degrees Celsius $\left({ }^{\circ} \mathrm{C}\right)$ as follows:

$$
{ }^{\circ} \mathrm{C}=\left({ }^{\circ} \mathrm{F}-32\right) / 1.8
$$

Vertical coordinate information is referenced to the National Geodetic Vertical Datum of 1929 (NGVD 29).

Horizontal coordinate information is referenced to the North American Datum of 1927 (NAD 27).

Altitude, as used in this report, refers to distance above the vertical datum.

*Transmissivity: The standard unit for transmissivity is cubic foot per day per square foot times foot of aquifer thickness [(f $\left.\left.\mathrm{ft}^{3} / \mathrm{d}\right) / \mathrm{ft}^{2}\right] \mathrm{ft}$. In this report, the mathematically reduced form, foot squared per day $\left(\mathrm{ft}^{2} / \mathrm{d}\right)$, is used for convenience.

Specific conductance is given in microsiemens per centimeter at 25 degrees Celsius $\left(\mu \mathrm{S} / \mathrm{cm}\right.$ at $\left.25^{\circ} \mathrm{C}\right)$.

Concentrations of chemical constituents in water are given either in milligrams per liter (mg/L) or micrograms per liter $(\mu \mathrm{g} / \mathrm{L})$. 


\title{
Hydrogeology of the Mogollon Highlands, Central Arizona
}

\author{
By John T.C. Parker, William C. Steinkampf, and Marilyn E. Flynn
}

\section{Abstract}

The Mogollon Highlands, 4,855 square miles of rugged, mountainous terrain at the southern edge of the Colorado Plateau in central Arizona, is characterized by a bedrock-dominated hydrologic system that results in an incompletely integrated regional ground-water system, flashy streamflow, and various local water-bearing zones that are sensitive to drought. Increased demand on the water resources of the area as a result of recreational activities and population growth have made necessary an increased understanding of the hydrogeology of the region. The U.S. Geological Survey conducted a study of the geology and hydrology of the region in cooperation with the Arizona Department of Water Resources under the auspices of the Arizona Rural Watershed Initiative, a program launched in 1998 to assist rural areas in dealing with water-resources issues. The study involved the analysis of geologic maps, surface-water and ground-water flow, and water and rock chemical data and spatial relationships to characterize the hydrogeologic framework.

The study area includes the southwestern corner of the Colorado Plateau and the Mogollon Rim, which is the eroded edge of the plateau. A 3,000- to 4,000-foot sequence of early to late Paleozoic sedimentary rocks forms the generally south-facing scarp of the Mogollon Rim. The area adjacent to the edge of the Mogollon Rim is an erosional landscape of rolling, step-like terrain exposing Proterozoic metamorphic and granitic rocks. Farther south, the Sierra Ancha and Mazatzal Mountain ranges, which are composed of various Proterozoic rocks, flank an alluvial basin filled with late Cenozoic sediments and volcanic flows. Eight streams with perennial to intermittent to ephemeral flow drain upland regions of the Mogollon Rim and flow into the Salt River on the southern boundary or the Verde River on the western boundary. Ground-water flow paths generally are controlled by large-scale fracture systems or by karst features in carbonate rocks. Stream channels are also largely controlled by structural features, such as regional joint or fault systems. Precipitation, which shows considerable variability in amount and intensity, recharges the ground-water system along the crest of the Mogollon Rim and to a lesser extent along the crests and flanks of the rim and the Mazatzal Mountains and Sierra Ancha. Flashy runoff in the mainly bedrock stream channels is typical. Springs are distributed throughout the region, typically discharging at or above the contact of variably permeable formations along the face of the Mogollon Rim with a scattering of low-discharge springs in the Proterozoic rocks below the rim.

The surface of the Colorado Plateau is the primary recharge area for the $\mathrm{C}$ aquifer in which ground-water flows north toward the Little Colorado River and south toward the Mogollon Highlands. Within the study area, flow from the $\mathrm{C}$ aquifer primarily discharges from large, stable springs in the upper East Verde River, Tonto Creek, and Canyon Creek Basins along the top of the Mogollon Rim and to the west as base flow in West Clear Creek. On the basis of chemical evidence and the distribution and flow characteristics of springs and perennial streams, the $\mathrm{C}$ aquifer is also the source of water for the limestone aquifer that discharges from carbonate rocks near the base of the Mogollon Rim. Vertical flow from the $\mathrm{C}$ aquifer, the base of which is in the Schnebly Hill Formation, recharges the limestone aquifer that discharges mainly at Fossil Springs in the western part of the study area and as base flow in Cibecue Creek on the eastern edge of the study area. 


\section{Hydrology of the Mogollon Highlands, Central Arizona}

Local, generally shallow aquifers of variable productivity occur in plateau and mesa-capping basalts in the sedimentary rocks of the Schnebly Hill and Supai Formations, in fractured zones of the Proterozoic Payson granite, and in the alluvium of the lower Tonto Creek Basin. Where time series data exist, such water-bearing zones are shown to be sensitive to short-term climatic fluctuations, in particular, the drought which began in the mid-1990s and continued during the course of this study.

A regional water budget for the $\mathrm{C}$ and limestone aquifers was developed from precipitation, spring, and streamflow data. Of an estimated 1,730,000 acre-feet of precipitation that falls on the Mogollon Rim annually, about 8 percent is estimated to recharge the regional aquifers. About 40 percent of recharge to the limestone aquifer is estimated to be leakage from the overlying $\mathrm{C}$ aquifer.

\section{Introduction}

The Mogollon Highlands of east central Arizona is a region of forested plateau and mountains, deep, sheerwalled canyons, and desert valleys. Known for its scenic beauty and characterized by a generally mild climate, the area, though still sparsely populated, attracts an increasing number of tourists and summer residents. Furthermore, the permanent population is expected to nearly double during the next 50 years. Consequently, there is increased pressure on the water resources of this area for a number of sometimes conflicting uses. Rational management of water resources is necessary to meet increased domestic requirements while ensuring an adequate supply of water for commercial and agricultural use, for Indian lands, and for preservation of valued environmental elements, including surface waters, riparian woodlands, forest and grassland areas, and wildlife and aquatic habitat. Such management requires an understanding of the relations between different components of the hydrologic system-recharge areas, surface flows, shallow aquifers, deep aquifers, discharge areas, and the regional ground-water flow system-and how each is affected by geology, climate, topography, and human use.

\section{Purpose and Scope}

This report presents the findings of an investigation into the hydrogeology of the Mogollon Highlands (fig.1) conducted by the U.S. Geological Survey (USGS) in cooperation with the Arizona Department of Water Resources (ADWR) under the auspices of the State of Arizona Rural Watershed Initiative (RWI). The study is one of three conducted by the USGS in a contiguous area covering about $17,000 \mathrm{mi}^{2}$ in central and northern Arizona (fig. 2). The purpose of the RWI is to provide assistance to rural Arizona communities in defining and solving local water resources issues. The purpose of the USGS studies is to increase understanding of the ground-water flow systems in the Mogollon Highlands, the middle and upper Verde River watersheds, and the Coconino Plateau and in particular to assess the extent and availability of water resources, define ground-water flow paths and the relations among different sources of ground water, define the relations between surfacewater flow and ground water, and assess the effects of continued development on the water resources of the areas.

The basic objectives of this study are to:

1. Develop an understanding of the hydrogeologic framework, which is the relation between geologic units and hydrologic properties.

2. Define the relations among the different components of the hydrologic system, namely the interactions among climate, water use, and surfacewater and ground-water systems.

3. Synthesize the findings into a conceptual model that can be used for water-resources management purposes and will support the development of an interpretive numerical model to examine the effects of climate and water use on the sustainability of regional water resources.

The scope of work included collection, compilation, and analyses of existing hydrologic, chemical, and geologic data to describe the spatial and temporal behavior of the hydrologic system. For the most part, the study considers the hydrological system beginning in the mid-20th century during a period of considerable water-resources development and through two periods of extreme drought. Additional data collected during the course of the study included spring-discharge measurements and water-chemistry analyses for purposes of delineating the ground-water flow paths in both regional and local aquifers. The report presents these findings and uses them to present a conceptual model of the hydrologic system and a water budget for the regional aquifers of the study area. 
Introduction 3

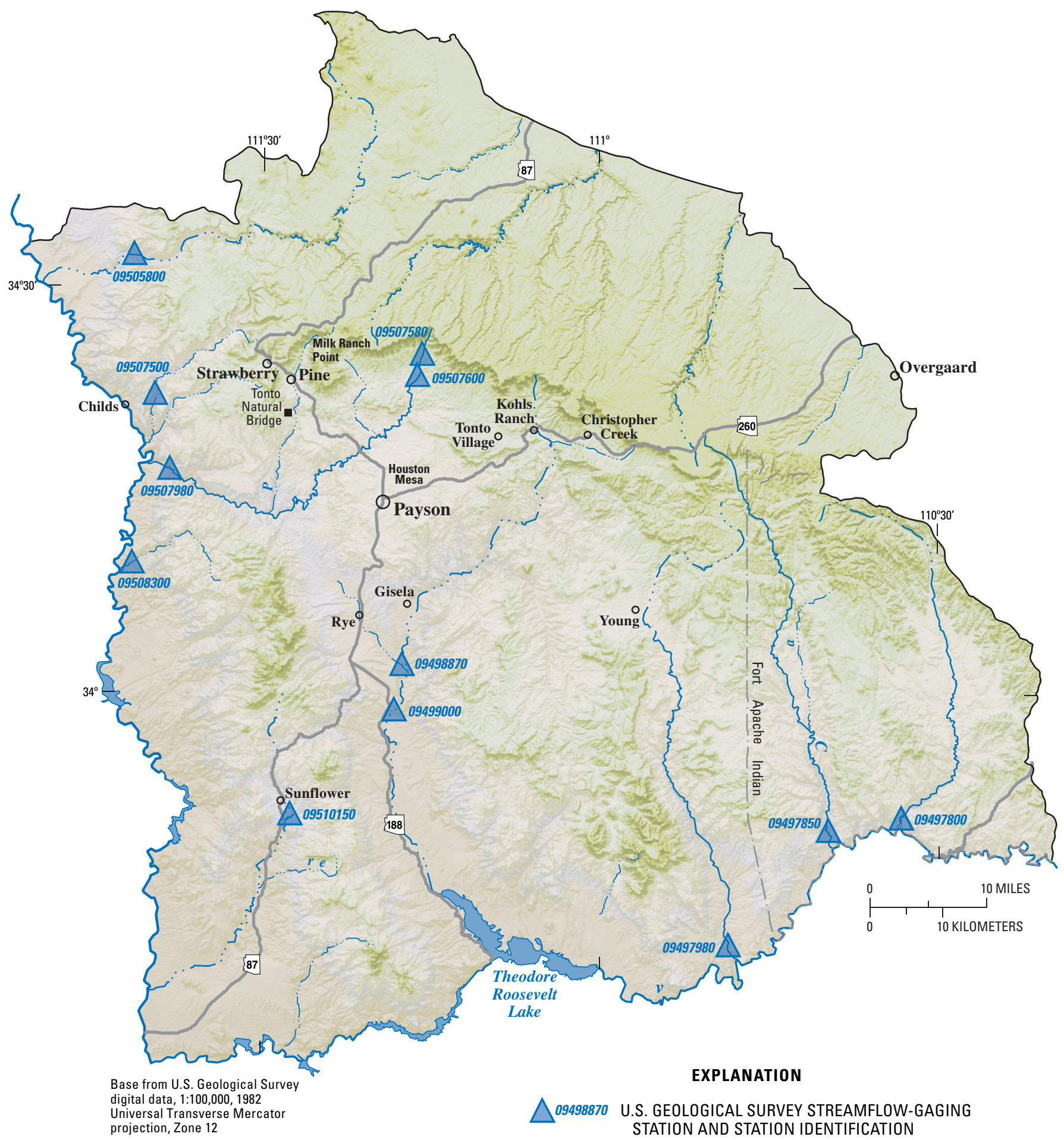

Figure 1. Study area and U.S. Geological Survey streamflow-gaging stations in the Mogollon Highlands, central Arizona. 


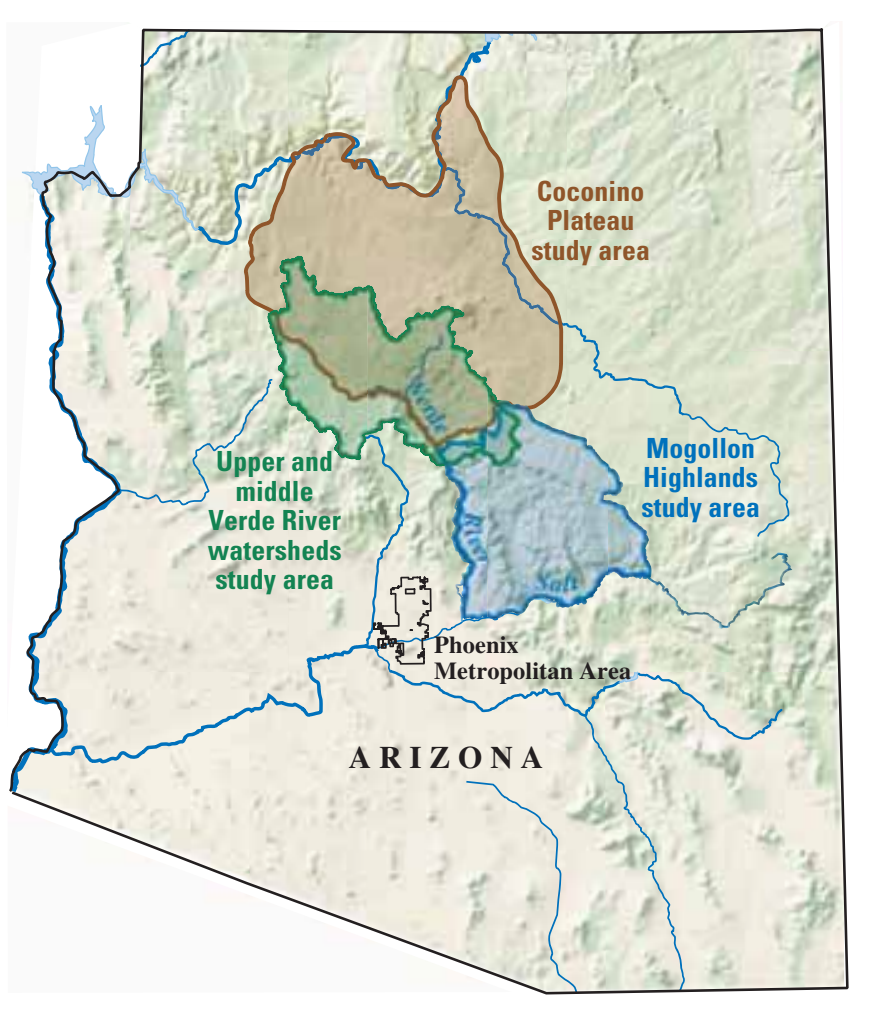

Figure 2. U.S. Geological Survey Rural Watershed Initiative study areas.

\section{Acknowledgments}

The Pine-Strawberry Water Improvement District provided supplemental funding through the ADWR for this project; the Northern Gila County Water Plan Alliance provided technical and community support for the project; Robert Sejkora, Arizona State Parks, provided data on spring flow at Tonto Natural Bridge State Park; Kevin Bright, Arizona Game and Fish Department provided data on spring flow at the Tonto Creek and Canyon Creek fish hatcheries; Grant Loomis, U.S. Department of Agriculture (USDA) Forest Service, Tonto National Forest, provided data on discharge measurements at Fossil Creek and Tonto Creek; Michael Ploughe, town of Payson and Arizona Hydrologic Sources, provided data on wells in the Payson area and for a well in the community of Pine; Dr. Donald Burt, Arizona State University, provided an overview of the geology of the study area; several property owners granted access to springs for water sampling and discharge measurements.

\section{Description of the Study Area}

The Mogollon Highlands, as defined in this study, consists of four distinct physiographic regions (fig.1) The northern part of the study area is the southernmost part of the Colorado Plateau, a region formed by the broad uplift of lightly deformed rocks that covers more than 75,000 $\mathrm{mi}^{2}$ of Arizona, Utah, Colorado, and New Mexico (Fenneman, 1931). The Mogollon Rim, which trends generally northwest-southeast through the study area, is the eroded edge of the Colorado Plateau and is characterized in the study area by a well-delineated, steep to nearly vertical scarp about 2,000 $\mathrm{ft}$ high. The crest of the Mogollon Rim is the narrow strip of land above the scarp separating the drainages of the Gila River from the drainage of the Little Colorado River that are well to the south and north of the study area, respectively (fig. 2). Below the steepest part of the Mogollon Rim, referred to here as the face, the landscape is characterized by tablelands generally bounded by the scarps of large regional faults (fig. 1). Along the eastern side of the study area, the tablelands form a broad, rugged plateau that flanks the eastern side of the Sierra Ancha to the Salt River. To the south, the study area mainly is within the transitional zone that separates the Colorado Plateau from the Basin and Range Physiographic Province. Most of the study area is characterized by rugged, rocky terrain, especially on the face of the Mogollon Rim and in the two mountain ranges, the Mazatzal Mountains and the Sierra Ancha that flank lower Tonto Creek on the west and east, respectively (fig. 1). The lower Tonto Basin and the middle reaches of Cherry Creek near the town of Young (fig. 1) contain the only significant area of alluvial valley bottoms. Total relief is about 6,700 feet with the highest point on Baker Butte above the Mogollon Rim at an altitude of $8,077 \mathrm{ft}$, and the lowest point at the confluence of the Salt and Verde Rivers at an altitude of about 1,330 ft (fig. 1).

The Mogollon Rim and the Colorado Plateau, at altitudes of 6,000 ft and above, are covered mainly with a conifer forest dominated by ponderosa pine. Smaller stands of ponderosa pine forest occupy the higher ridges and peaks south of the Mogollon Rim. Piñon pine and juniper woodlands dominate the tablelands and the northern slopes of the Mazatzal Mountains and much of the northern part of the Sierra Ancha. The ponderosa and piñon-juniper forests cover almost 60 percent of the study area. A severe infestation of pine-bark beetle beginning in 2002 has resulted in high mortality of ponderosa and piñon pine throughout much of north-central Arizona. Some stands of ponderosa pine have suffered as much as 80 to 90 percent mortality during the outbreak that has been blamed on severe drought and overcrowding of trees. In April 2002, nearly 50 percent of the ponderosa pine forest in Tonto National 
Forest was affected by the infestation, and the winter of 2003 was considered favorable for continued spread of the infestation (DeGomez, 2002, 2003). Most other hillslopes are covered with interior chaparral vegetation consisting of woody shrubs and oak species. Desert grasslands occupy the valley floors above about $3,000 \mathrm{ft}$, and upland Sonoran desert vegetation dominates below that altitude. From June 18 to July 7, 2002, the largest fire to date in Arizona history burned 467,066 acres of forest and brushland in the east-central part of the State, including much of the Cibecue Creek watershed along the eastern edge of the study area (U.S. Department of Agriculture, Forest Service, 2003).

Population of the study area is approximately 24,400, of which almost 60 percent is in the town of Payson (fig.1; U.S. Census Bureau, 2000). According to the Arizona State Land Department, about 80 percent of the land is owned by the Federal Government, primarily within the Tonto National Forest, and about 15 percent of the land is included within five Indian reservations. Only 2.4 percent of the land within the study area is privately owned. Water use is almost entirely municipal and domestic, and virtually all water comes from ground-water sources. Annual ground-water withdrawals by the town of Payson, which is the largest consumer of water in the area, increased at an average rate of about 8 percent a year from 268 acre- $\mathrm{ft}$ in 1975 to about 1,706 acre-ft in 2000 (fig. 3; Ploughe, 2001). Water-use figures for the rest of the study area have not been as diligently reported, but in 1997, the most recent year for which generally complete data are available, 17 water companies reported a combined annual water use of 670 acre-ft (Arizona Corporation Commission, written commun., 2000).

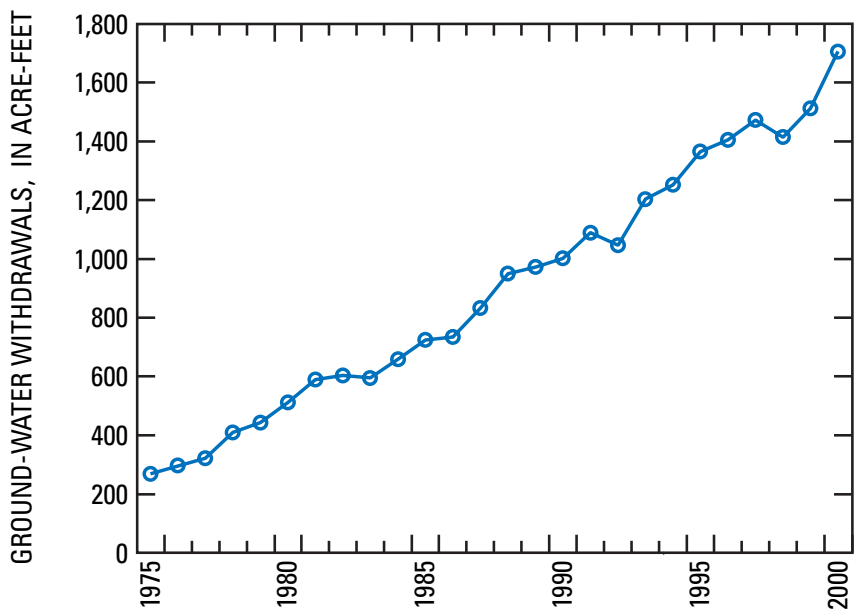

Figure 3. Annual ground-water withdrawals by the town of Payson, Arizona (Ploughe, 2001).

\section{Previous Investigations}

Feth and Hem (1963) conducted the first detailed hydrogeologic investigation with an inventory of springs and a general description of the geology of upland areas of north-central Arizona that included the Mogollon Highlands. In many cases, spring-discharge data reported in that study are the only such data available for the study area. The report also described likely recharge paths from the crest of the Mogollon Rim to the underlying waterbearing rocks. Ross (1977) published the first description of ground-water conditions in the Mogollon Highlands area based on well data, primarily in the Payson and PineStrawberry areas. Denis (1981) conducted a more comprehensive survey of ground-water conditions throughout the Tonto Basin using well data. Hart and others (2002) conducted a regional study of the $\mathrm{C}$ aquifer that overlapped somewhat with the study area of this investigation. They produced a potentiometric map of the $\mathrm{C}$ aquifer along the crest of the Mogollon Rim that indicates possible flow paths into the ground-water system of the Mogollon Highlands study area.

Water-resources issues have provided the impetus for several recent studies for the town of Payson, including Southwest Ground-water Consultants, Inc. (1998), Ploughe (2000, 2001), and Gæorama, Inc. (2001, 2003). Southwest Ground-water Consultants, Inc. (1998) projected future water needs for the town of Payson and estimated the extent of water resources developed at the time of the study. Southwest Ground-water Consultants, Inc. also described the relation of structural features within the Payson granite (fig. 4) to the ground-water system and presented detailed mapping of faults and lineaments. Ploughe $(2000,2001)$ described results of exploratory well-drilling and monitoring of wells in granitic rocks north of Payson. Gæorama, Inc. (2001, 2003) presented the results of detailed mapping of the Diamond Rim Fault system (fig. 4) east of Payson and reported on hydrogeologic characteristics of the Payson granite and related rocks from which Payson draws its water. Similar studies were conducted east of Payson by AGRA Earth and Environmental, Inc. (1999) for the Arizona Department of Transportation, which was seeking to secure a water supply for the major upgrading of State Route 260 east of Payson (fig. 1). 


\section{Hydrology of the Mogollon Highlands, Central Arizona}

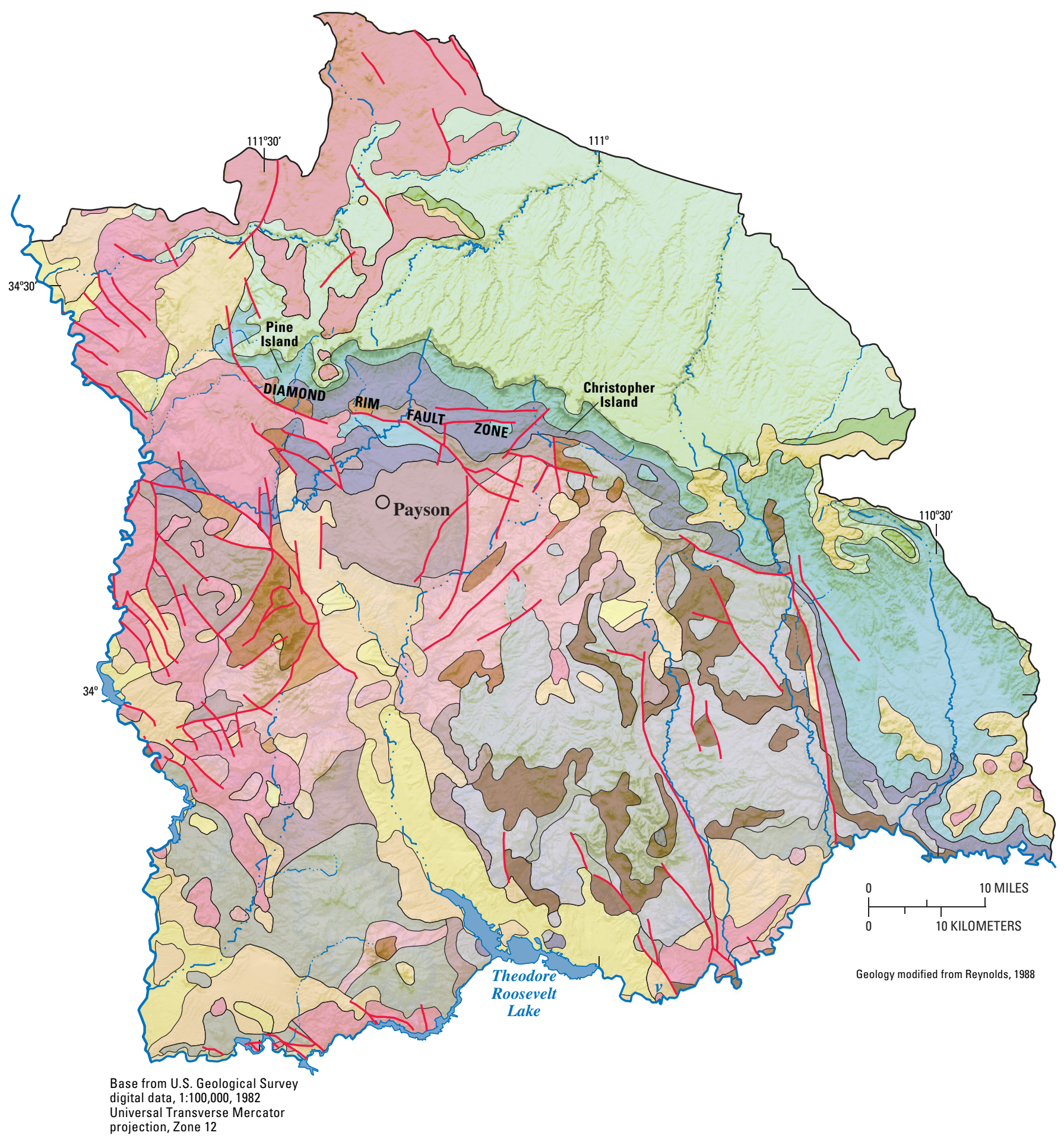

Figure 4. Geology and geologic structure of the Mogollon Highlands, central Arizona. 


\section{EXPLANATION}

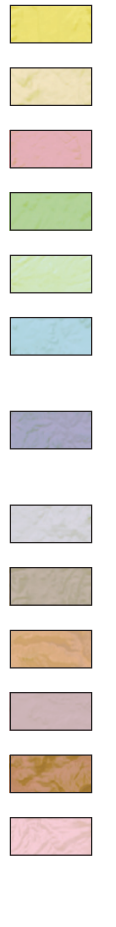

SURFICIAL DEPOSITS, MOSTLY ALLUVIUM-Holocene to Middle Pleistocene

SEDIMENTARY ROCKS—Pliocene to Middle Miocene

VOLCANIC ROCKS-Pliocene to Middle Miocene

SEDIMENTARY ROCKS, UNDIFFERENTIATED-Cretaceous

SEDIMENTARY ROCKS — Permian (Kaibab Formation and Coconino Sandstone)

SEDIMENTARY ROCKS—Permian and Pennsylvanian (Schnebly Hill Formation, Supai Formation, and Naco Formation)

SEDIMENTARY ROCKS-Mississippian to Cambrian (Redwall Limestone, Martin Formation, and Tapeats Sandstone)

SEDIMENTARY ROCKS-Middle Proterozoic (Apache Group)

DIABASE-Middle Proterozoic

GRANITOID ROCKS-Middle Proterozoic

GRANITOID ROCKS - Early Proterozoic (Payson granite)

QUARTZITE - Early Proterozoic (Mazatzal Group quartzite of Tonto Supergroup)

METASEDIMENTARY AND METAVOLCANIC ROCKS, DIFFERENTIATED-Early Proterozoic

(Tonto Supergroup: Red Rock Group, Alder Group, East Verde River Formation)

FAULT

Figure 4. Continued.

In the Pine-Strawberry area (fig. 1), Weitzman (2002) surveyed the geology and hydrology south of the Mogollon Rim between Strawberry and the headwaters of the East Verde River north of Payson. His work included the detailed geologic mapping of the Buckhead Mesa and upper East Verde River area, and he plotted ground-water flow paths along Pine Creek and the East Verde River (fig. 1). Kaczmarek (2003) investigated the hydrogeology of the Pine-Strawberry area and concluded that prolonged pumping of wells that tap the Schnebly Hill Formation and the Supai Formation (fig. 4) results in decreased yields over time. Wells in the Strawberry area that draw water from the Schnebly Hill Formation were found to be somewhat more reliable than those in the Pine area that draw water from the Supai Formation because the porosity of the Schnebly Hill Formation allows for some storage of water within those rocks. In the Supai Formation, Kaczmarek (2003) found, water is produced entirely from fractures, and there is no significant storage in the essentially impermeable rocks. He concluded that neither formation is an adequate resource to meet current and future water demands in the area. Using the few available borehole data and the analysis of discharge from Fossil Springs, Kaczmarek concluded that the limestone aquifer, consisting of the Martin Formation, Redwall Limestone, and possibly the Naco Formation (fig. 4), may provide a dependable source of water at a depth of more than 1,500 ft below the land surface in Strawberry.

\section{Geology}

The significant geologic components of the Mogollon Highlands (fig. 4) are (1) the Paleozoic sedimentary rocks of the Colorado Plateau that are exposed like the edge of a card deck on the face of the Mogollon Rim; (2) Proterozoic metamorphic and granitic rocks that underlie the Paleozoic sedimentary rocks and form the rolling, step-like terrain south of the Mogollon Rim; (3) Proterozoic metamorphic, sedimentary, and volcanic rocks that form the Sierra Ancha and Mazatzal Mountain ranges; (4) a system of generally northwest-southeast trending faults associated with Basin and Range extensional deformation; and (5) late Cenozoic volcanic rocks that overlie the Paleozoic section in the northeastern part of the study area, and late Cenozoic volcanic and basin-fill sediments primarily in the lower Tonto Creek Basin. 


\section{Hydrology of the Mogollon Highlands, Central Arizona}

\section{Geologic History}

Proterozoic rocks record a period of volcanism, sedimentation, and deformation that concluded about 1.7 billion years ago (Karlstrom and others, 1987; Conway and Silver, 1989). Subsequently, the Proterozoic rocks constituted the surface of several positive areas in what is now eastern Arizona that affected deposition patterns throughout the Paleozoic Era. The main area of positive relief was in the region of the Defiance Uplift, a structural feature formed during the Laramide deformational episode in the Cretaceous Period about 150 mi northeast of the study area. Pine Ridge is a buried extension of that uplift that extends beneath the Mogollon Rim with an arm extending south toward Pine and another arm extending south toward Christopher Creek (fig. 1; Teichert, 1965). Although relief generally was low on this positive area, it at times formed a barrier to transgressing seas during the time that the lower Paleozoic sedimentary rocks of the study area were being deposited. Consequently, such units in the Mogollon Highlands are often thinner and less continuous than their equivalents in Grand Canyon and elsewhere on the Colorado Plateau and southeastern Arizona. Two islands delineated by outcrops of Mazatzal Group quartzite near Pine and Christopher Creek (fig. 4) stood above base level throughout the early Paleozoic Era, truncating deposition until they were buried by sediments in the Mississippian Period or Early Pennsylvanian Epoch (Teichert, 1965; McKee and Gutschick, 1969).

The first Paleozoic deposition was a layer of sandstone that was deposited in a braided stream environment at the edge of the North American craton. Teichert (1965) called this unit the "basal sandstone" and considered it Devonian in age, but Hereford (1977) found the unit to be lithologically similar to the Tapeats Sandstone of Cambrian age, which immediately overlies Proterozoic rocks in the upper Verde River Basin and Grand Canyon. Assuming the Cambrian designation is correct, the Mogollon Highlands then underwent a long period of erosion, nondeposition, or both, producing a stratigraphic unconformity representing at least 80 million years.

Shallow marine conditions prevailed during the Devonian and Mississippian Periods when the carbonate rocks of the Martin Formation and Redwall Limestone were deposited. Deposition of both units was truncated against the quartzite cliffs of the Pine and Christopher Creek islands. A long period of surface exposure in the Late Mississippian Epoch led to the development of a karst topography that includes extensive caves and sinkholes throughout central Arizona; karst features are particularly extensive and well developed in the study area, presumably reflecting the greater duration of exposure in the Mogollon Highlands than occurred over more negative areas of the State. The period of surface exposure was followed by renewed shallow marine conditions in the Early Pennsylvanian Epoch with deposition of the mainly carbonate rocks of the Naco Formation (Brew, 1965). The gradual transition from Naco Formation carbonate rocks to overlying siltstones and sandstones records the fluctuating position of the coastline in Late Pennsylvanian time. Increasingly terrestrial conditions prevailed during the deposition of the Supai Formation in the Late Pennsylvanian and Early Permian Epochs. Fluvial sediments were laid down in coastal marshes and flood plains to produce the red siltstones and sandstones that characterize most of the formation. In the middle Permian Period, mudstones, evaporites, and carbonates were deposited in the Holbrook Basin to form the Schnebly Hill Formation, which includes the carbonate Fort Apache Member in the middle of the depositional sequence (Blakey, 1990).

The record of Paleozoic deposition within the study area concluded with another period of shallow marine conditions and deposition of the Kaibab Formation (Hopkins, 1990); the subsequent Mesozoic history is missing because of erosion. According to Bilodeau (1986), the Mogollon Rim area was the site of a surface of gentle relief he termed the Mogollon Slope, across which volcanic ash and fluvial sediments were transported to the northeast from a volcanic arc terrane in southern Arizona and Mexico.

The next episode in the formation of the present-day geologic setting of the Mogollon Highlands was the uplift of the Colorado Plateau, possibly in late Cretaceous time during the period of Laramide deformation (Bilodeau, 1986). Formation of the Mogollon Rim was a result of Basin and Range extensional tectonics along the southern margins of the plateau and the subsequent cliff erosion parallel to major faults (Mayer, 1979). The last major geologic event in the region was a period of volcanism in middle Miocene times that saw mainly basaltic lava flows over the crest of the Mogollon Rim at the western edge of the study area and into Fossil Creek canyon. Lava deposition also occurred in the Mazatzal Mountains along the edges of the Tonto Creek valley in the lower basin. 


\section{Description of Geologic Units}

Geologic mapping of the study area has not been as detailed relative to other parts of Arizona until recently, in part because of the absence of significant mineral resources. Most of the study area falls within Gila County for which geologic mapping was done by Wilson and others (1959) and State-level mapping was done by Reynolds (1988). Geologic mapping was done for the Strawberry and Pine 7.5-minute quadrangles northwest of Payson by Weir and Beard (1997) and Weisman and Weir (1990), respectively. Detailed stratigraphic studies of rocks that occur in the study area, particularly the Paleozoic sedimentary rocks, have been conducted by Brew (1965), Teichert (1965), McKee and Gutschick (1969), Hereford (1977), and Blakey (1990). Proterozoic rocks and associated structure have been extensively mapped by Conway (1976), Karlstrom and others (1987), Conway and Silver (1989), Cox and others (2002), and Gæorama, Inc. (2003). The geologic units described here have been generalized from those mapped by Reynolds (1988).

\section{Cenozoic Rocks}

Tertiary volcanic rocks cover much of the western Mogollon Rim as far east as Milk Ranch Point where Baker Butte (fig. 1), the highest point in the study area, stands above basalt flows (fig. 4). Lava flows fill the canyon west of Fossil Creek to a thickness of more than 3,000 ft (Twentner, 1962) and spill onto Hardscrabble Mesa to the south where flows are nearly 2,000 ft thick. In addition to basalt flows, volcanics in the region include tuff, agglomerates, cinders and interspersed fluvial deposits (Weisman, 1984). Potassium-argon dating of the basalt from the top of Baker Butte yielded an age of $11.4 \pm 0.27$ million years and from the base of the top flow layer on the southern end of Milk Ranch Point yielded an age of $14.23 \pm 0.74$ million years (Peirce and others, 1979). Stratigraphic relations show that the Mogollon Rim pre-dates all the basalt flows in the area although abundant basalt float on slopes beneath Milk Ranch Point is testament to some degree of cliff retreat since emplacement of the basalt flows.

The Tonto Creek Basin below Payson is the site of the most significant basin-fill deposits in the study area (figs. 1 and 4). Tertiary and Quaternary colluvial, alluvial-fan, stream-terrace, pediment-terrace, and fluvial deposits interlayered with basalt flows fill the basin to depths of 1,000 to 3,500 ft (Richards, 1987; Mayes,
1990). Mesa-capping gravels and sedimentary rocks of Oligocene to Miocene age that are both preceded and followed by Basin and Range faulting are exposed mainly along the western and southern boundaries of the study area (Reynolds, 1988) and are not differentiated here from other late Cenozoic sedimentary units.

\section{Upper Paleozoic Rocks}

Middle to Late Permian age rocks form the cap of the Mogollon Rim except where buried by younger volcanic rocks (fig. 4). The Permian Coconino Sandstone is a clean, aeolian sandstone that forms a nearly vertical escarpment at the top of the Mogollon Rim (Blakey, 1990). The unit varies greatly in thickness; it is an erosional veneer on top of Milk Ranch Point but attains a maximum thickness of nearly $1,200 \mathrm{ft}$ above the headwaters of the East Verde River (Reynolds, 1988). The fine- to medium-grained sandstone is extensively crossbedded, is heavily fractured, and is in gradational contact with the underlying Schnebly Hill formation (Blakey, 1990).

The Permian Kaibab Formation is a fossiliferous limestone containing chert nodules and interbeds of layered chert, shale, and poorly cemented sandstone reflecting the near-shore depositional environment of the unit in the study area (Weisman, 1984; Hopkins, 1990). A measured section of the Kaibab Formation on the Mogollon Rim above Strawberry Canyon (fig. 4) showed a thickness of about $300 \mathrm{ft}$ lying unconformably over the Coconino Sandstone (Weisman, 1984).

\section{Middle Paleozoic Rocks}

Rocks of Pennsylvanian to Early Permian age form the middle slopes of the Mogollon Rim from Fossil Creek, where they are buried beneath younger volcanic flows, southeast to the Salt River (fig. 4). The Pennsylvanian age Naco Formation unconformably overlies the Redwall Limestone with a basal red shale composed of reworked residuum that fills the underlying, uneven karst surface (Brew, 1965). The contact generally is hidden beneath slopes of colluvium. All stratigraphic and lithologic descriptions of the Naco Formation that follow are from Brew (1965) and from observations made during this study. Above the shale, the Naco Formation consists mainly of discontinuous, ledge-forming, light gray nodular limestones in tabular beds from less than $1 \mathrm{ft}$ thick to $10 \mathrm{ft}$ thick and more, alternating with layers of purple to red siltstone and shale. Orange chert is locally 
present in the limestone, and some units are highly fossiliferous. Measured sections show thicknesses of more than $400 \mathrm{ft}$ at Fossil Creek and north of the East Verde River; measured sections along Tonto Creek show a thickness of about $114 \mathrm{ft}$ north of Highway 260, and a thickness of nearly $240 \mathrm{ft}$ near Kohls Ranch (figs. 1 and 4). The Naco Formation thickens to more than 1,000 ft east of the study area on the Fort Apache Indian Reservation.

According to Blakey (1990), the suite of reddish to yellow sandstones, siltstones, and shales that constitute the lower half of the Mogollon Rim escarpment are here separated into the lower and upper parts of the Supai Formation and the overlying Schnebly Hill Formation. The Supai Formation's contact with the underlying Naco Formation is transitional, and placement of that contact is within a complex 100 - to $200-\mathrm{ft}$ interval of limestone, mudstone, and sandstone, which Blakey (1990) notes is poorly exposed and difficult to map. All descriptions of the Supai and Schnebly Hill Formations that follow are from Blakey (1990). The lower part of the Supai Formation of Pennsylvanian age is about $300 \mathrm{ft}$ thick and consists primarily of very fine-grained massive sandstone, cross-stratified sandstone, and conglomerate that range in color from reddish gray to reddish brown to pale grayish orange. The unit forms ledges, steep slopes, and local cliffs. The upper part of the Supai Formation, which averages about $300 \mathrm{ft}$ in thickness, contains a variable assemblage of sandstone and conglomerate red beds, which generally are of local extent with abrupt lateral changes. At Fossil Creek, the middle of the upper part of the formation contains a complex suite of fluvial features and deposits with several fining-upward sequences, cross-stratified sandstones, conglomerate beds, and accumulations of organic material including plant debris. On the basis of regional correlations, Blakey (1990) places the Pennsylvanian-Permian boundary at the top of the channeled complex.

The Permian Schnebly Hill Formation is in sharp contact with the underlying Supai Formation and is the product of deposition in a rapidly subsiding closed basin. The unit is exposed along the full length of the Mogollon Rim within the study area, forming steep slopes at Fossil Creek where it is about $835 \mathrm{ft}$ high and thickens slightly to the east. The bottom $425 \mathrm{ft}$ of the Schnebly Hill Formation is poorly exposed, very finegrained sandstone and reddish-brown siltstones. A little more than half way up the sequence, the Fort Apache Member is a 50- to 60-ft-thick carbonate unit that consists mainly of limestone in the study area and becomes more dolomitic to the north; the upper parts of the formation consist of siltstone, mudstone, and some carbonates capped by a $130-\mathrm{ft}$ sequence of extensively cross-stratified sandstone that thins to the east from Fossil Creek.

\section{Lower Paleozoic Rocks}

Rocks of Cambrian to Mississippian age are exposed continuously along the base of the Mogollon Rim from Pine Creek southeast to the Salt River (fig. 4), as well as in several fault blocks north and east of Payson and as outliers scattered throughout the southern part of the study area. The Cambrian Tapeats Sandstone lies unconformably upon the Payson granite and is exposed north of Payson on Houston Mesa (figs. 1 and 4), along the East Verde River and along the base of the Diamond Rim Fault north of Webber Creek and as far east as Kohls Ranch (figs. 1 and 4). Within the study area, the Tapeats Sandstone is a very coarse-grained sandstone to small pebble conglomerate with thin, lenticular beds of shale and siltstone. In vertical sections, it shows distinct crossbedded sandstone and conglomerate that fill channels cut into underlying beds (Hereford, 1977).

The Devonian age Martin Formation lies unconformably over the Tapeats Sandstone in the East Verde River area and directly overlies Proterozoic rocks farther to the east. Exposures of the unit, which forms vertical, blocky cliffs of well-bedded dolomite, limestone, and clastic sedimentary rocks, are visible along State Highway 87 between Payson and Pine north of the East Verde River crossing (figs. 1 and 4); on the eastern side of the canyon above Tonto Natural Bridge; along most canyon walls that are cut into the Paleozoic section of the Mogollon Rim, including Webber Creek, the East Verde River, Tonto Creek, Christopher Creek, and Canyon Creek; along the Diamond Rim escarpment; and along the north bank of the Salt River east of Cibecue Creek. The Martin Formation consists of two members (Teichert, 1965). The lower Becker Butte Member reportedly is as thick as $160 \mathrm{ft}$, but it is not exposed or is missing in most measured sections. Teichert (1965) describes it as having a basal crossbedded sandstone and conglomerate below a dolomitic sandstone and shale, but Hereford (1977) believes that only the dolomitic sandstone is part of the Martin Formation, and that the basal sandstone is the Tapeats Sandstone. The Jerome Member can include any of the following units: (1) a finely laminated lower unit at the base called the fetid dolomite that is up to 55-ft thick; (2) an aphanitic dolomite up to 159-ft thick that may be sandy and in some places contains chert; and (3) an upper sequence as much as $385-\mathrm{ft}$ thick that contains beds of fine to coarse-grained mottled dolomite, which east of the East Verde River contains varying amounts of sandstone, siltstone, and shale (Teichert, 1965). Isopach 
maps of the Jerome Member show the unit as thickening from less than $100 \mathrm{ft}$ northeast of the Mogollon Rim above Christopher Creek to more than $300 \mathrm{ft}$ parallel to the rim and to nearly $400 \mathrm{ft}$ at Tonto Natural Bridge Spring (Teichert, 1965). The Martin Formation is also shown as pinching out around the margins of Pine and Christopher Islands (fig. 4).

Throughout much of the study area, the Redwall Limestone of Mississippian age is little more than a layer of rubble, the residuum of extended weathering of the Redwall surface during a period of surface exposure that lasted tens of millions of years before deposition of the overlying Naco Formation (Brew, 1965). Of the four members of the formation that are present in the Grand Canyon, where the unit is nearly $800 \mathrm{ft}$ thick, only the Mooney Falls Member, the second youngest member, is present east of Fossil Creek (McKee and Gutschick, 1969). East of Pine, McKee and Gutschick's isopach maps show the Redwall Limestone generally to be less than $50 \mathrm{ft}$ thick, not counting residuum, and to pinch out to the northeast of the Mogollon Rim in approximately the same area as the Martin Formation does. West of Pine, isopach maps show the Redwall abruptly thickening to more than $100 \mathrm{ft}$ at Fossil Creek. Well cuttings and geophysical evidence at a recently developed well northwest of Pine, however, were interpreted as showing a thickness of $495 \mathrm{ft}$ of Redwall Limestone, a much greater thickness for the unit than previously reported in that area (Michael Ploughe, hydrologist, Arizona Hydrologic Sources, oral commun., 2003). The residuum typically consists of a conglomerate containing pebbleto boulder-sized limestone gravel and white pebble- to cobble-sized chert in a red clay matrix (McKee and Gutschick, 1969). Fossils are abundant in some exposures. In exposures along State Highway 87 north of the East Verde River (figs. 1 and 4), the residuum comprises nearly 50 percent of the total thickness of the Redwall, and at exposures along Tonto Creek, it comprises nearly 40 percent of the formation's total thickness. The intact part of the Redwall Limestone consists of various textures of light-gray limestone that form knobby outcrops. Bedding, where present, ranges from 2 to $12 \mathrm{ft}$ thick, but massive, unbedded outcrops are common. The limestone may contain a variety of fossils, including brachiopods, corals, horn corals, and foraminifers. The upper part of the Mooney Falls Member is a clean limestone that is permeable and susceptible to solution, so that it is often honeycombed with solution openings along bedding and joint surfaces. Measured sections within the study area are $38 \mathrm{ft}$ (16 ft of residuum) at Colcord Canyon near the base of the
Mogollon Rim at the eastern end of the study area (figs. 1 and 4), $80 \mathrm{ft}$ (30 ft of residuum) at Tonto Creek north of Kohls Ranch, and $31 \mathrm{ft}$ at Tonto Natural Bridge (no residuum; figs. 1 and 4). Southeast from Colcord Canyon the Redwall thickens to $316 \mathrm{ft}$ ( $95 \mathrm{ft}$ of residuum) in the Salt River canyon (McKee and Gutschick, 1969).

\section{Proterozoic Rocks}

Proterozoic sedimentary, volcanic, and metamorphic rocks are exposed mainly south of the Mogollon Rim within the Mazatzal Mountains and Sierra Ancha (figs. 1 and 4). The Tonto Super Group includes within its nearly 30,000 ft-thick sequence from top to bottom, the 1.70 billion year old Mazatzal Group consisting mainly of quartzite, shale, and a basal conglomerate; the 1.70 billion year old Red Rock group consisting of rhyolitic ash, tuff, and flows; the 1.71 billion year old Alder Group consisting of alternating sequences of volcanic rocks, sand and siltstone, ash flows and basalt, and shale, sandstone, and carbonate rocks; and the 1.72 billion year old East Verde River Formation consisting of graywacke sandstones and ash flow tuff (Cox and others, 2002). Only the Mazatzal Group is exposed within the Mogollon Rim itself where it appears within fault blocks at the base of Paleozoic sedimentary rocks in Pine Creek at Tonto Natural Bridge and just south of the community of Pine (figs. 1 and 4).

The Mazatzal Group rocks are also exposed in the lower reach of Christopher Creek near its confluence with Tonto Creek (figs. 1 and 4). Quartzites in the Mazatzal Group, which include the Mazatzal Peak Quartzite and the lower-lying Deadman Quartzite generally are coarse to fine grained with good preservation of primary depositional features such as ripples and crossbedding (Cox and others, 2002). Proterozoic sedimentary rocks of the Apache Group and diabase are exposed over much of the eastern Sierra Ancha (fig. 4).

Proterozoic plutonic rocks include the Payson granite and associated granophyres and rhyolite intrusions, which are about 1.69 to 1.70 billion years old (Karlstrom and others, 1987) and are exposed over a $128 \mathrm{mi}^{2}$ area informally known as the Payson Shelf (figs. 1 and 4). The Payson granite intrudes the mafic rocks of the Gibson Creek batholith south of Payson (Conway, 1976) and a complex of gneissic granitoids north of the town (AGRA Earth and Environmental, 1999). Both of the mafic complexes are included with the Payson granite map designation (fig. 4). The Payson granite is also exposed on the northwestern and southeastern edges of the Mazatzal Mountains and in scattered exposures along upper Cherry Creek. The Payson granite is a tan to reddish potassium feldspar and quartz-rich granite with numerous intrusions of 


\section{Hydrology of the Mogollon Highlands, Central Arizona}

silica-rich, finer-grained, alkali-rich granite that form ridges and hills because they are more resistant to weathering and erosion than the host rock. Weathering of the Payson granite is most developed where the unit is close to the overlying Tapeats Sandstone; outcrops of the rock are sparse in the town of Payson because of deep weathering and the accumulation of grus, the residual particles of resistant quartz and feldspars that are the remains of the original rock.

\section{Structure}

The region's geologic history has left a substantial structural imprint on rocks in the study area. Tectonic stresses have raised land surface and deformed rock formations and have enabled erosional forces to dramatically sculpt the landscape. The overlying sedimentary beds are relatively flat-lying and generally dip gently to the northeast. Within fault blocks, the lowermost formations in this assemblage dip 10 degrees or more (Gæorama, Inc., 2003).

Faulting has been sporadic. Major Proterozoic faults and lineaments trend northeast-southwest across the structural trend of more recent faulting and generally are highly silicified (Gæorama, Inc., 2003). The Slate CreekBreadpan Canyon Shear Zone defines the middle reaches of the Tonto Creek canyon through the Sierra Ancha (fig. 4; Karlstrom and others, 1987).

The most abundant faults, however, and those most significant in controlling the modern landscape are the product of a Miocene episode of crustal extension that has left a generally north-south to northwest-southeast trending structural fabric (fig. 4; Reynolds, 1988). This activity yielded high-angle normal and reverse faults throughout the Basin and Range Physiographic Province. In the Mogollon Highlands, major extensional faults show displacements of as little as 50 to $100 \mathrm{ft}$ locally and as much as 600 to $1,500 \mathrm{ft}$ on the Diamond Rim Fault north of Payson and where it crosses the East Verde River (fig 4; Gæorama, Inc., 2003). The Diamond Rim Fault, which dips 75 to 80 degrees to the south and is upthrown on the northern side, is the major regional fault in the study area and extends $30 \mathrm{mi}$, generally eastwest from east of Tonto Creek to Pine Creek (Conway 1976, Wrucke and Conway, 1987), and likely continues for some distance west of Pine Creek (Gæorama, Inc., 2003). The juxtaposition of crystalline and sedimentary formations caused by such displacements plays a significant role in the development of surface drainage, determination of ground-water flow directions, and the occurrence and distribution of springs below the Mogollon Rim as faults variably enable or preclude drainage of water-bearing formations.
Fracturing of rocks by jointing is apparent in several geologic units, particularly the Payson granite, the rocks of the Coconino Sandstone and Schnebly Hill Formation near the top of the Mogollon Rim, and the Tertiary volcanic rocks in the northwestern part of the study area. Fractures affect recharge, ground-water flow paths, and the location of springs. An unpublished synthesis of geophysical data shows evidence of large-scale fracture systems within Paleozoic sedimentary rocks that extend from the face of the Mogollon Rim northward beneath the Colorado Plateau (Mark Gettings and Mark Bultman, geologists, U.S. Geological Survey, written commun., 2003). Within carbonate rocks, fracture systems may be enlarged by dissolution of rocks to create opportunities for karstic ground-water flow.

\section{Climate}

Precipitation and temperature generally vary with altitude throughout the study area; some variation is attributable to local rain-shadow effects. Precipitation contours closely parallel the topographic features of the study area; the highest annual amounts occur in a narrow band along the crest of the Mogollon Rim (fig. 5). Mean precipitation over the entire study area is about $21.3 \mathrm{in} / \mathrm{yr}$. Mean monthly maximum temperatures, occurring in June and July range from more than $100^{\circ} \mathrm{F}$ in the Sonoran Desert near Roosevelt Lake to the mid$80 \mathrm{~s}^{\circ} \mathrm{F}$ in the ponderosa forests of the Mogollon Rim and Colorado Plateau. Mean minimum temperatures range from the upper- $30 \mathrm{~s}^{\circ} \mathrm{F}$ in the lowest parts of the region to between 10 and $20^{\circ} \mathrm{F}$ in the upland areas (Sellers and others, 1985).

Precipitation results primarily from two types of storms: intense, convective thunderstorms in the summer and less intense but more regional, frontal storms in the winter. Tropical storms, which tend to be more regional than convective thunderstorms but produce locally intense precipitation, occasionally deliver large amounts of precipitation, usually in late September and October (Sellers and others, 1985). At higher altitudes, much of the winter precipitation falls as snow; annual mean snowfall ranges from about 48 in. at Blue Ridge Ranger Station at an altitude of 6,880 $\mathrm{ft}$ to $24 \mathrm{in}$. at Payson at an altitude of about 4,900 ft (fig. 5). Precipitation is spread somewhat equably throughout the year; it is only slightly less in spring than in the other three seasons (National Climatic Data Center, 2003a; fig. 6). 


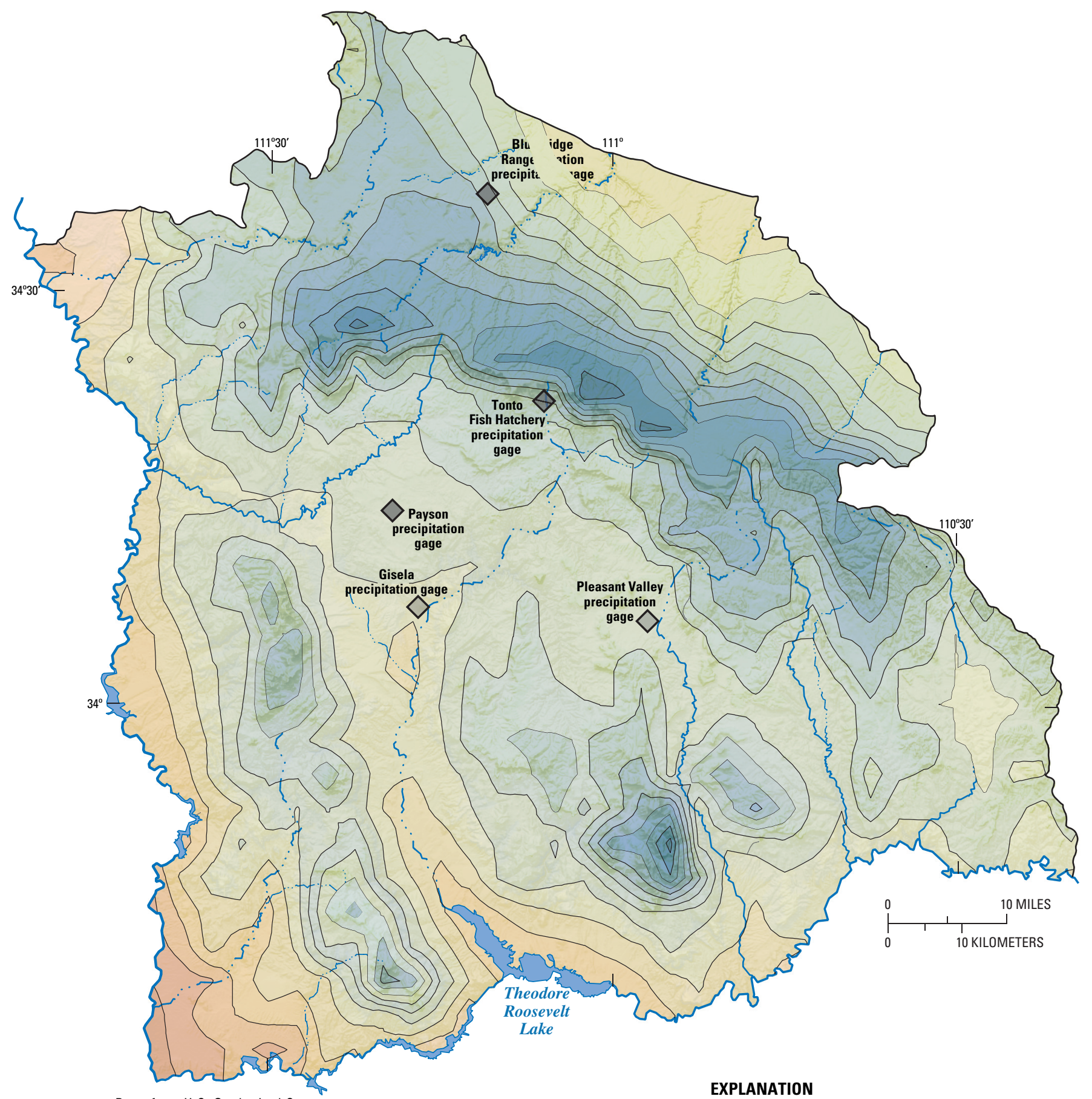

Base from U.S. Geological Survey digital data, 1:100,000, 1982 Universal Transverse Mercator projection, Zone 12
AVERAGE ANNUAL PRECIPITATION, IN INCHES:

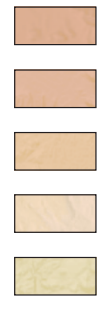

$17-19$

$19-21$

$21-23$

23-25

$25-27$

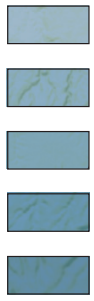

$27-29$

29-31

$31-33$

33-35

Greater than 35

Figure 5. Average annual precipitation and locations of active weather stations in the Mogollon Highlands, central Arizona. 


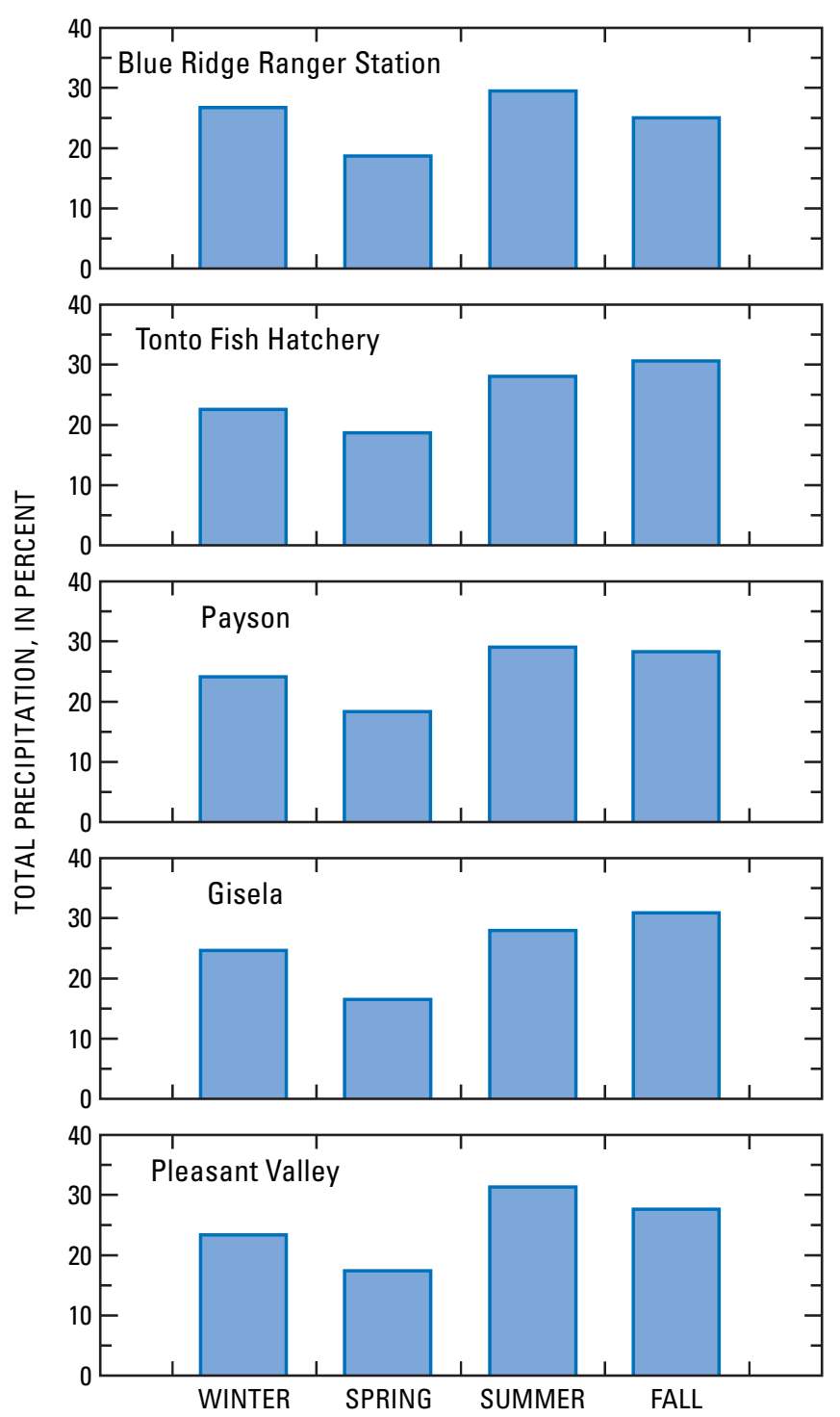

Figure 6. Seasonal distribution of precipitation for selected sites in the Mogollon Highlands, central Arizona.

For the active weather stations within the Mogollon Highlands that have a period of record extending to the 1950 s or earlier, certain precipitation trends are apparent. Examination of the precipitation record for selected stations shows a cluster of lower annual precipitation during the 1950s with a less pronounced cluster of low precipitation beginning in the 1990s (fig. 7A). The pattern is clearer at the Tonto Fish Hatchery and the Payson and Gisela stations and less so at Pleasant Valley. Average decadal precipitation and variability show limited change from one decade to another. The 1980s is the wettest decade at all four stations; however, the driest decade on record is different at all four stations (table 1).
During the course of this investigation, the Mogollon Highlands was undergoing a period of severe drought to the extent that most of the study area was within the most severely drought-stricken part of Arizona throughout 2002 and much of 2003. The drought, which extended throughout the Southwest, was the most severe since the 1950s (National Climate Data Center, 2003b). The 1950s drought appears to be characterized by greater extremes of low precipitation than other periods (fig. 7A), including the most recent drought period; however, an examination of the temperature record at Payson (fig. 7B) shows a major rise in mean annual temperature since 1989. Such temperatures can affect evapotranspiration, snowfall, and snowmelt in ways that would account for the historically high values of the Palmer Hydrologic Drought Index in the early 2000s. (National Climate Data Center, 2003b, 2003c).

\section{Hydrology}

The hydrologic system of the Mogollon Highlands is characterized by a surface network of short, steep stream channels that drain the upland regions and flow into the Salt River, including Theodore Roosevelt Lake, on the southern boundary of the study area, or the Verde River on the eastern boundary (fig. 1). Ground-water flow paths generally are controlled by large-scale fracture systems or by karst features in carbonate rocks. Stream channels are also largely controlled by structural features, such as regional joint or fault systems.

Precipitation, which shows considerable variability in amount and intensity, recharges the ground-water system along the crest of the Mogollon Rim and, to a lesser extent, along the crests and flanks of the Mazatzal Mountains and Sierra Ancha. Flashy runoff in the generally bedrock stream channels is typical. Springs are distributed throughout the region, typically discharging at or above the contact of variably permeable formations.

Drought and the limited surface- and near-surface water resources have resulted in not-infrequent water shortages for more than a century. Anecdotal reports describe declining ground-water levels and the drying up of previously productive springs and creeks between 1882 and 1922 that were attributed to an increase in well production; an 18-month drought in 1904-1905 reportedly devastated the cattle ranching industry (Northern Gila Historical Society, 1984). Water shortages continue to plague the region, particularly in the Pine-Strawberry area (Arizona Department of Water Resources, written comm. 1984, 1996), one of many such areas that has organized to address rural water-supply issues under the auspices of the state of Arizona Rural Watershed Initiative. 
A. Normalized annual average precipitation for Mogollon Highlands

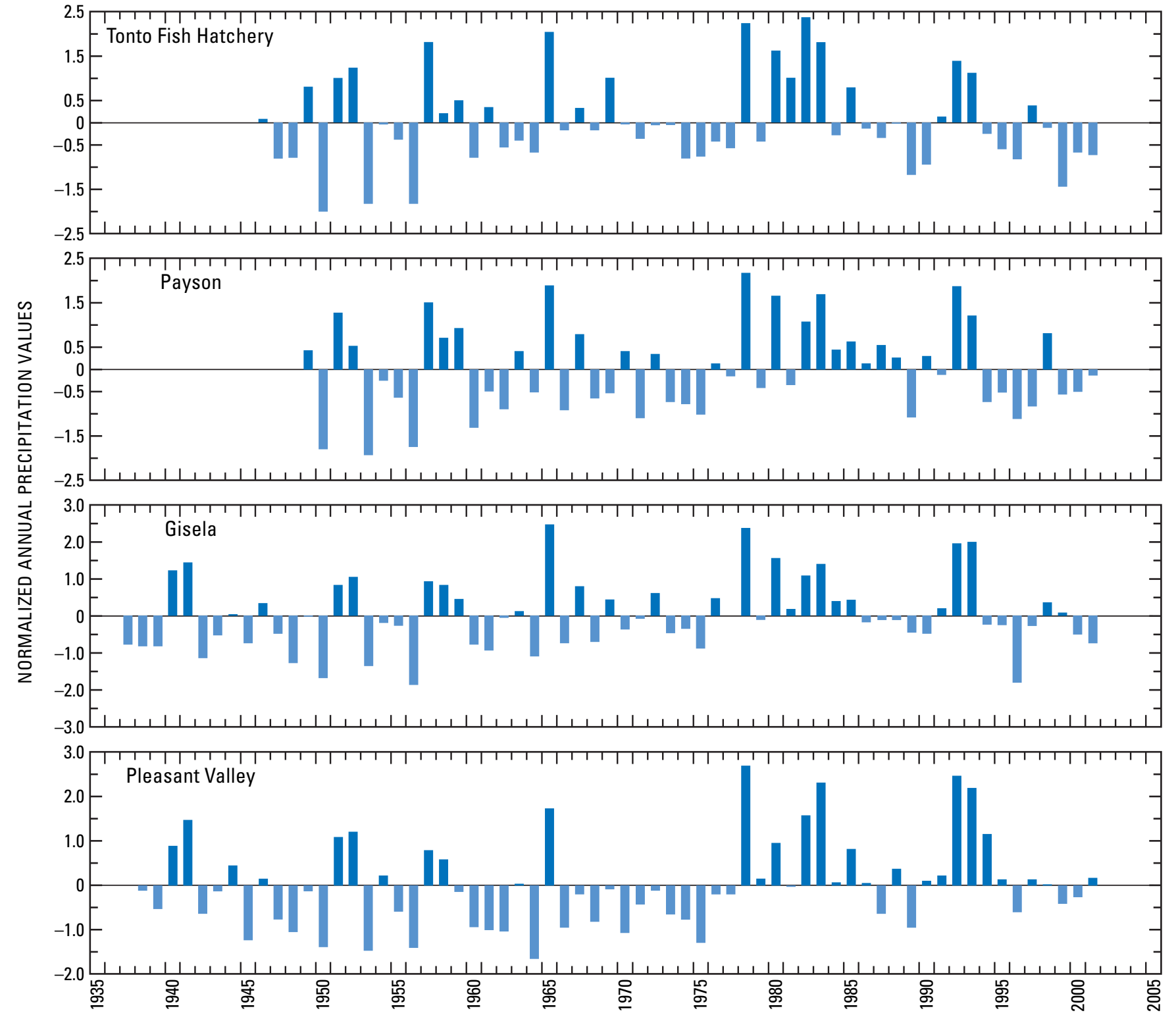

B. Normalized annual average temperature for Payson

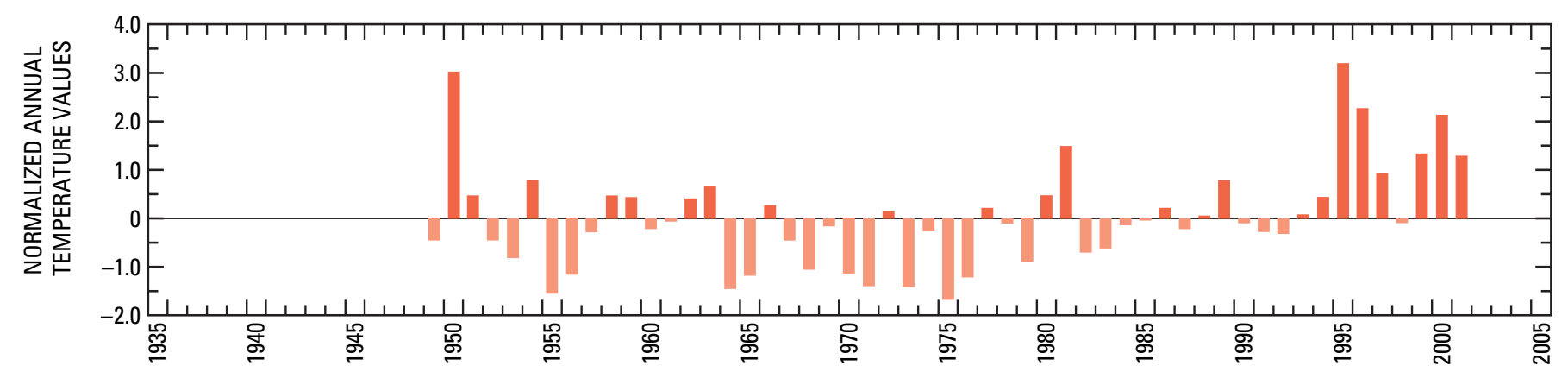

Figure 7. $A$, Normalized annual average precipitation for the Mogollon Highlands, central Arizona; $B$, Normalized annual average temperature for Payson, Arizona. Blue Ridge Ranger Station record begins in 1967 and is not shown here. 


\section{Hydrology of the Mogollon Highlands, Central Arizona}

Table 1. Summary precipitation statistics for Mogollon Highlands, Arizona, weather stations by decade

[Precipitation values are in inches. Data from National Climate Data Center, 2003a; ***, no record; ---, only three years of record for the period]

\begin{tabular}{|c|c|c|c|c|c|c|c|c|}
\hline Station & & $1940-49$ & $1950-59$ & $1960-69$ & $1970-79$ & $1980-89$ & 1990-2001 & $\begin{array}{l}\text { Period of } \\
\text { record }\end{array}$ \\
\hline \multirow{3}{*}{ Blue Ridge Ranger Station } & Mean & $* * *$ & *** & ---- & $\begin{array}{l}18.79 \\
\end{array}$ & 22.20 & 20.09 & 20.43 \\
\hline & Standard deviation & $* * *$ & 10.01 & 6.42 & 3.94 & 3.83 & 4.81 & 4.36 \\
\hline & Coefficient of variation & $* * *$ & .31 & .19 & .21 & .17 & .24 & .21 \\
\hline \multirow[t]{3}{*}{ Tonto Fish Hatchery } & Mean & $* * *$ & 31.99 & 33.26 & 32.03 & 37.47 & 31.36 & 33.04 \\
\hline & Standard deviation & $* * *$ & 10.01 & 6.42 & 7.30 & 8.93 & 6.74 & 7.89 \\
\hline & Coefficient of variation & $* * *$ & .31 & .19 & .23 & .24 & .21 & .24 \\
\hline \multirow[t]{3}{*}{ Pleasant Valley } & Mean & 20.38 & 20.33 & 18.40 & 19.94 & 23.20 & 23.14 & 20.92 \\
\hline & Standard deviation & 4.40 & 5.35 & 4.74 & 5.64 & 5.02 & 4.97 & 5.07 \\
\hline & Coefficient of variation & .22 & .26 & .26 & .28 & .22 & .22 & .24 \\
\hline \multirow[t]{3}{*}{ Payson } & Mean & $* * *$ & 21.73 & 20.99 & 20.60 & 23.40 & 21.20 & 21.53 \\
\hline & Standard deviation & $* * *$ & 6.44 & 5.13 & 5.22 & 4.08 & 5.12 & 5.13 \\
\hline & Coefficient of variation & $* * *$ & .30 & .24 & .25 & .17 & .24 & .24 \\
\hline \multirow[t]{3}{*}{ Gisela } & Mean & 17.07 & 16.99 & 17.41 & 18.31 & 19.90 & 17.81 & 17.70 \\
\hline & Standard deviation & 4.82 & 5.98 & 5.70 & 4.74 & 3.69 & 5.57 & 5.01 \\
\hline & Coefficient of variation & .28 & .35 & .33 & .26 & .19 & .31 & .28 \\
\hline
\end{tabular}

\section{Surface Water}

All of the major streams within the study area originate on the Colorado Plateau or the face of the Mogollon Rim and then flow eastward into the Verde River or southward into Theodore Roosevelt Lake or the Salt River (fig. 1). The largest streams generally are intermittent on the face of the Mogollon Rim and become perennial below the Mogollon Rim, and in some cases become ephemeral near the channel mouth. For the most part, the streams have cut bedrock channels that are covered with a thin layer of generally coarse-grained or sandy alluvium. Except in the lower Tonto Creek Basin and along middle reaches of Cherry Creek, flood plains generally are narrow or non-existent, and some reaches are confined within deep canyons.

The USGS has operated continuous-recording streamflow-gaging stations on all of the major streams in the study area (fig. 1 and table 2); however, the period of record is brief on Canyon Creek, and the gage at Fossil Creek measures only flow diverted for power plant use at the Arizona Power Service hydroelectric plant near Childs (fig. 1). Monroe (2002) modeled annual flows for Fossil Creek. He estimated that in years having a flood with a 2-year recurrence interval, annual flow would be about 35,230 acre-ft. Years in which a 5-year flood occurred would result in annual flow of about
68,510 acre-ft. Flow records on tributaries of the East Verde River and Tonto Creek are available, but the period of record is short.

During most flow conditions, the major streams are gaining in their downstream reaches. In the uppermost reaches, above major springs, flow typically occurs only during periods of runoff, but below such springs, baseflow is maintained year round. In some tributary streams, flow from source springs percolates through deep alluvium within a few thousand feet to several miles below the spring outlet, leaving some reaches dry much of the year (Feth and Hem, 1963; Brown and others, 1981; Kaczmarek, 2003). Perennial flow generally is reestablished on the major streams, however, well before the stream comes off the lower slopes of the Mogollon Rim.

Peak discharges of the largest perennial streams occur most often in winter or spring as a result of regional, frontal storms. Runoff during such storms is sometimes augmented by snowmelt. Winter storms account for most of the annual floods above the median peak discharge on all the gaged perennial streams draining the Mogollon Rim, although the flood of record on the East Verde River was caused by a monsoonal storm on September 5, 1970 (fig. 8). Summer storms account for the highest number of peak discharges on Rye Creek, which is a lowland, ephemeral stream. The 1970 flood was by far the largest recorded flood on Rye Creek (fig. 8). 
Hydrology 17

Table 2. Streamflow-gaging stations in the Mogollon Highlands, central Arizona, referred to in this report

[Data from Pope and others, 1998, and the U.S. Geological Survey National Water Information System database. Stations showing period of record to "present" were in service as of October 1, 2004]

\begin{tabular}{lclcc}
\hline \multicolumn{1}{c}{ Station name } & Station number & Period of record & Latitude & Longitude \\
\hline Cibecue Creek near Chrysotile & 09497800 & $1959-$ present & 335035 & 1103325 \\
Canyon Creek near Globe & 09497850 & $1975-81$ & 334947 & 1103950 \\
Cherry Creek near Globe & 09497980 & $1965-$ present & 334940 & 1105120 \\
Rye Creek near Gisela & 09498870 & $1965-85$ & 340157 & 1111726 \\
Tonto Creek above Gun Creek & 09499000 & $1940-$ present & 335848 & 1111810 \\
West Clear Creek near Camp Verde & 09505800 & $1964-$ present & 343219 & 1114136 \\
Fossil Creek Diversions near Camp Verde & 09507500 & $1952-$ present & 342206 & 1113956 \\
East Verde River Diversions from East Clear Creek & 09507580 & $1965-$ present & 342504 & 1111547 \\
East Verde River near Pine & 09507600 & $1961-71$ & 342330 & 1111605 \\
East Verde River near Childs & 09507980 & $1961-65$, & 341635 & 1113817 \\
Wet Bottom Creek near Childs & & $1967-$ present & & 1114132 \\
Sycamore Creek near Sunflower & 09508300 & $1967-$ present & 340939 & 1112709 \\
\hline
\end{tabular}


18 Hydrology of the Mogollon Highlands, Central Arizona
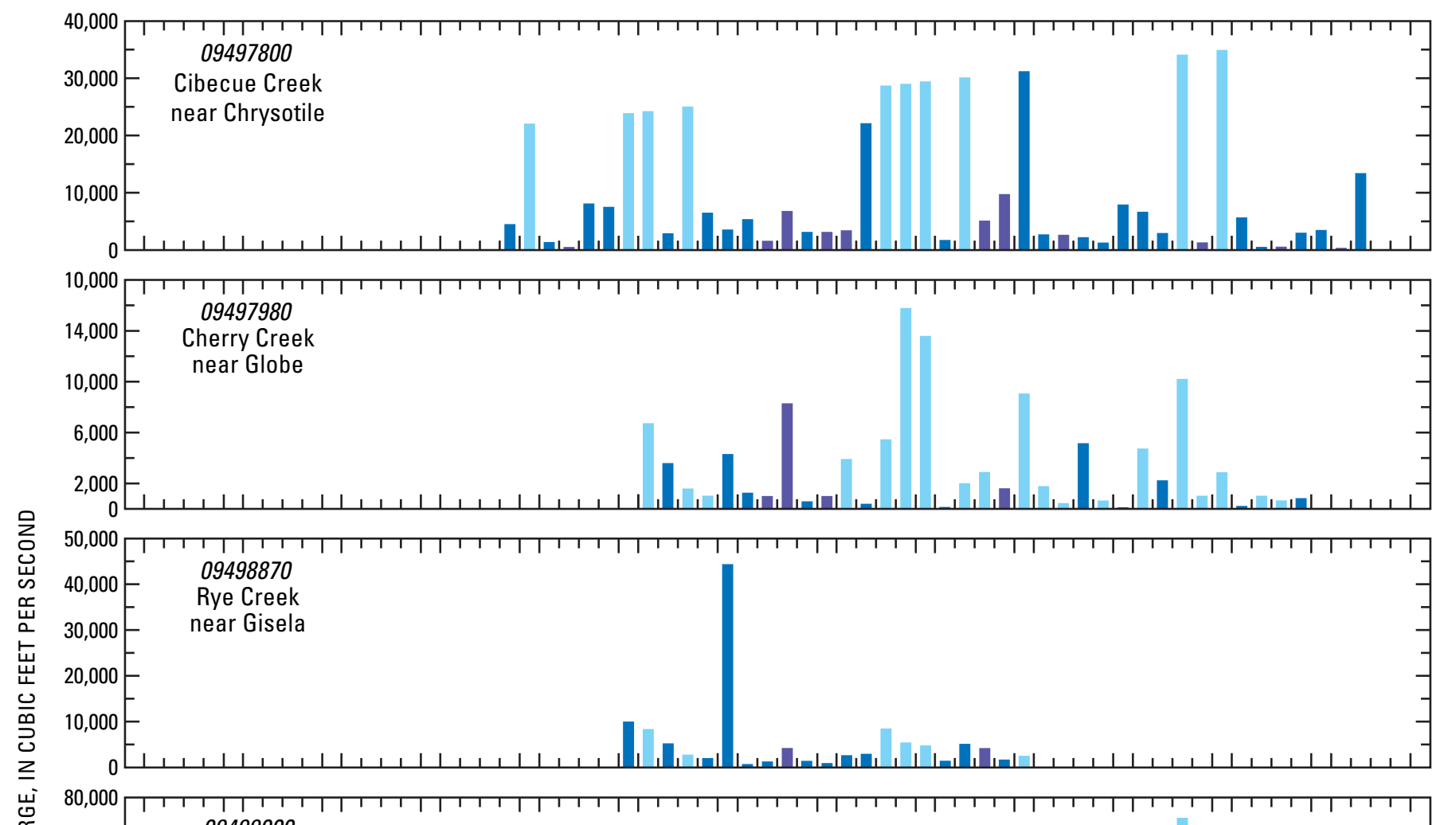

60,000 - Tonto Creek

- above Gun Creek

40,000

20,000

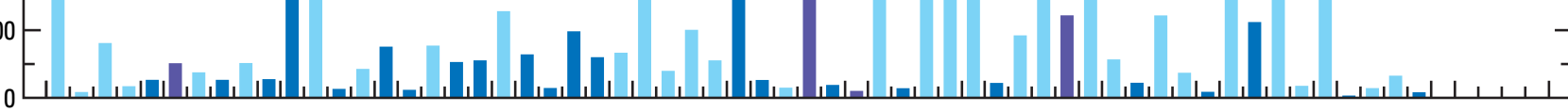
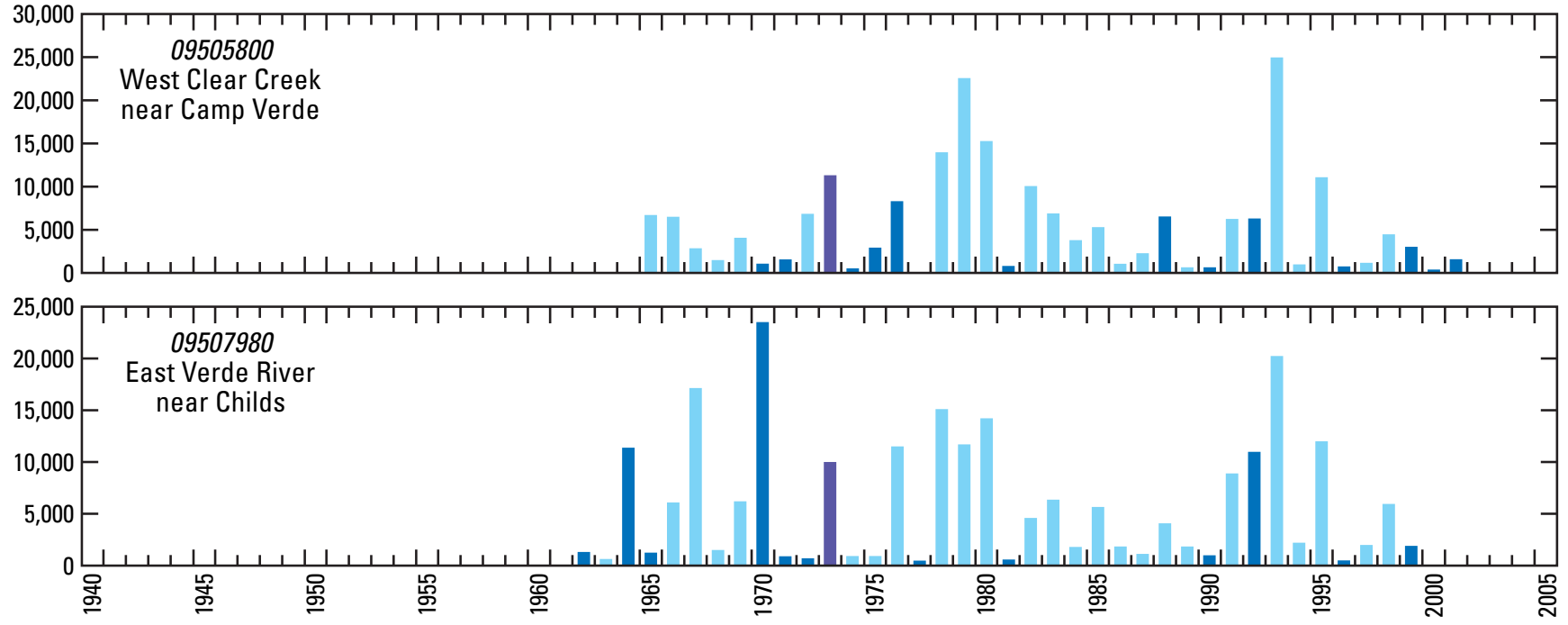

NOTE: Oblique number is U.S. Geological Survey streamflow-gaging station identifier

WATER YEAR

EXPLANATION

I SUMMER WINTER/SPRING IFALL

Figure 8. Seasonal distribution of annual peak discharges of selected streams in the Mogollon Highlands, central Arizona. 
Although the distribution of precipitation does not vary greatly throughout the year, all the streams for which continuous-flow records are available show that more than 70 percent of streamflow volume occurs during the winter and spring (fig. 9). The disproportionately high flow volumes from December through March reflect the difference in the nature of the runoff sources. Summer storms deliver short, intense bursts of precipitation over limited areas, and even exceptionally large storms of this nature may generate runoff over only a part of the watershed. Widespread frontal storms, especially when coupled with snowmelt, typically involve the entire watershed and are more likely to involve all the watersheds in the study area.

Daily mean discharges for the largest streams commonly fluctuate over three to four orders of magnitude in a single year and four to seven orders of magnitude over the period of record (fig. 10 and table 3 ). Among the five perennial streams that have active continuous-record gaging stations, the level of variability is about the same; Tonto Creek and Cherry Creek are somewhat more variable than West Clear Creek and the East Verde River, and Cibecue Creek shows the least variability. The two gaged streams that drain the western side of the Mazatzal Mountains, Wet Bottom Creek, which is ephemeral, and Sycamore Creek, which is intermittent (fig. 1), show the highest levels of variability (table 3). Rye Creek, an intermittent stream that drains the northeastern side of the Mazatzal Mountains (fig. 1), shows about the same degree of variability as the perennial streams; however, the period of record ended in 1985.

The most apparent trend in daily flows is a large increase in the frequency of the lowest flows in the early 21 st century with the exception of Cibecue Creek, which is striking in the degree to which it varies from the other streams in the study area (fig. 11). From 2000 through 2003 , the frequency of flows in the 2.5 percentile ranges from 2 to 30 times greater than in any previous decade or partial decade of record. Even if no further flows were to occur within the 2.5 percentile by the end of the decade, the period 2000-2009 would easily record the highest frequency of low flows at four of the five gages. Not only does Cibecue Creek record only one extreme low flow after 1999, the station shows a much greater frequency of low flows in the 1960s and 1970s than other stations, a trend that appears to have started at least as early as 1959 when 30 such flows occurred during only 7 months of record.

The singularity of Cibecue Creek's record perhaps indicates a greater lag between climatic conditions and flow conditions than at other stations. Another distinction among the various streams is the amount of discharge at the 2.5 percentile level. Tonto Creek and the East Verde River are at nearly zero flow at that level; Cherry Creek has a flow of $3.2 \mathrm{ft}^{3} / \mathrm{s}$; Cibecue Creek has a flow of $6.2 \mathrm{ft}^{3} / \mathrm{s}$; and West Clear Creek has a flow of $14 \mathrm{ft}^{3} / \mathrm{s}$ at that level and never records daily flows below $11 \mathrm{ft}^{3} / \mathrm{s}$ (table 3 ).
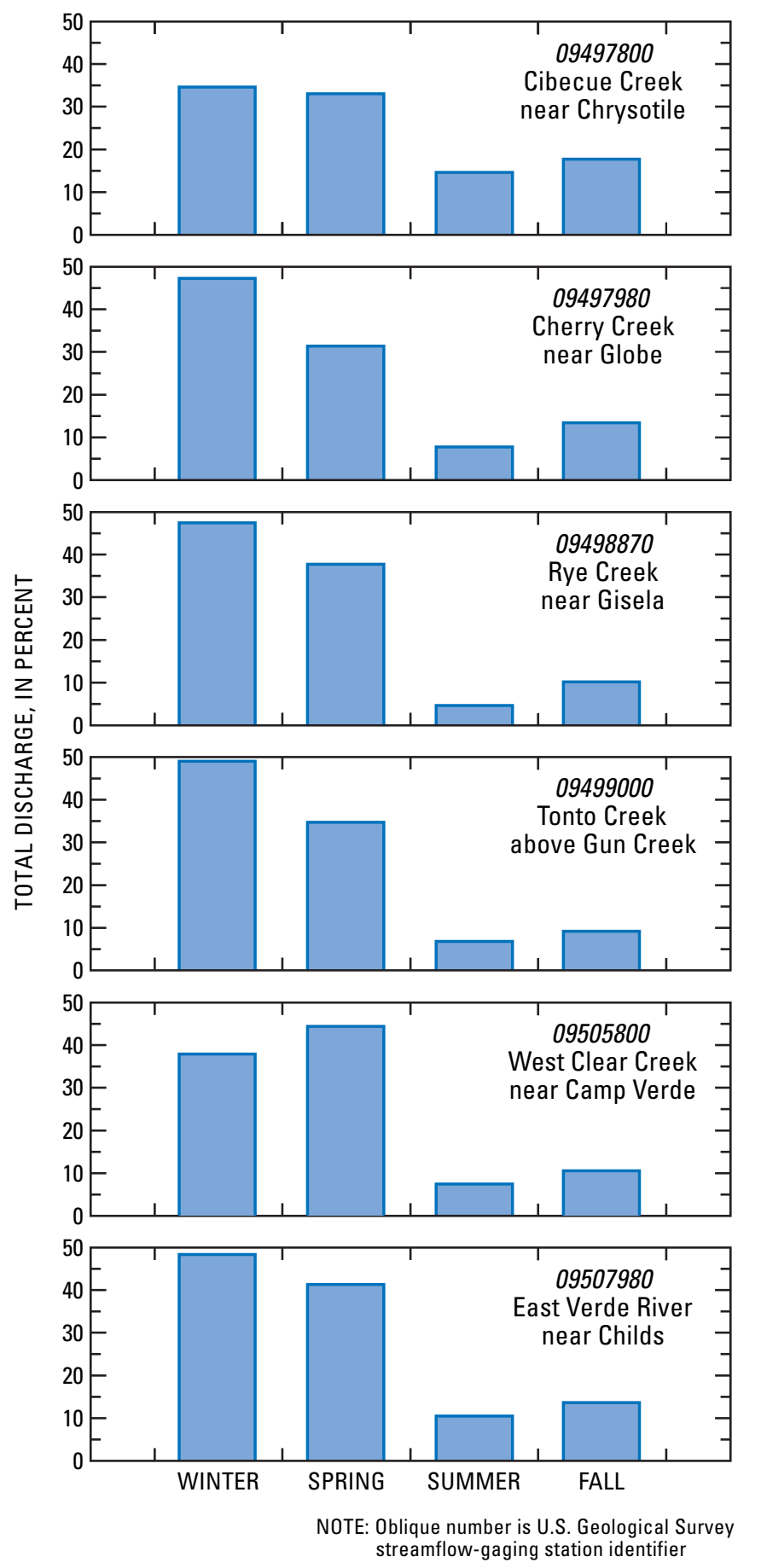

Figure 9. Seasonal distribution of discharge of selected streams in the Mogollon Highlands, central Arizona. 


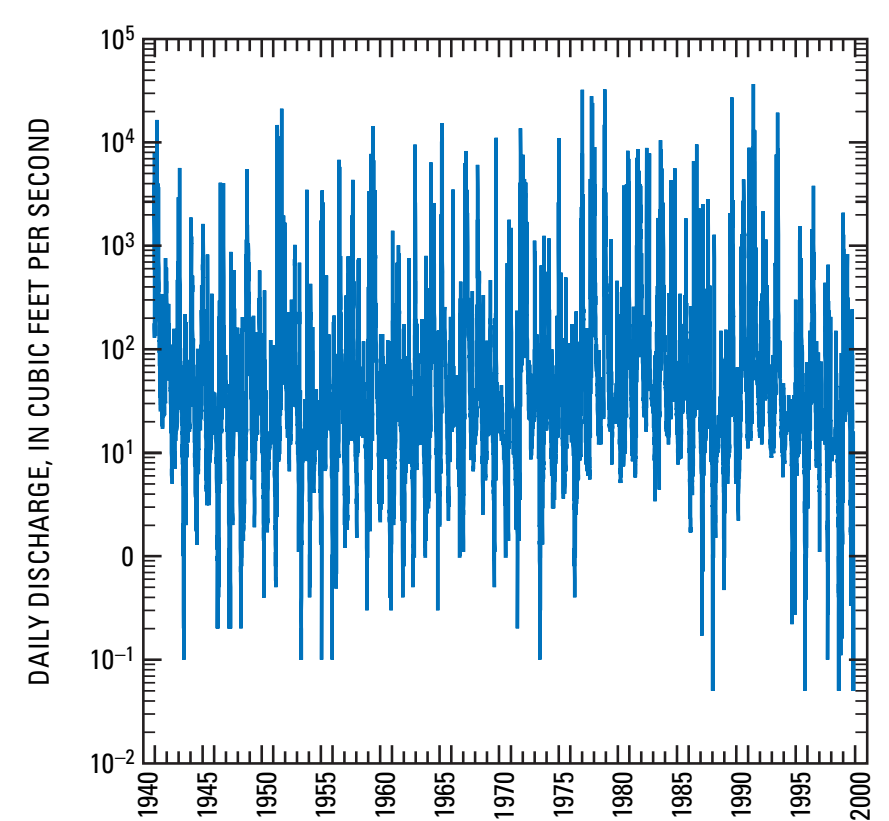

Figure 10. Daily discharge of Tonto Creek above Gun Creek showing typical range of daily discharge for Mogollon Highlands streams, central Arizona.

Table 3. Summary statistics of average daily streamflow values for active streamflow-gaging stations in the Mogollon Highlands, central Arizona

[Streamflow values are in cubic feet per second. Sycamore and Wet Bottom Creeks drain the Mazatzal Mountains, all others drain the Mogollon Rim]

\begin{tabular}{|c|c|c|c|c|c|c|}
\hline Station name & $\begin{array}{l}\text { Station } \\
\text { number }\end{array}$ & & 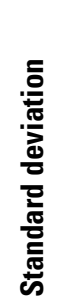 & 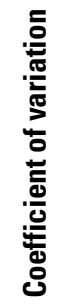 & 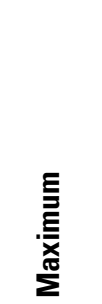 & 㤩 \\
\hline $\begin{array}{l}\text { Sycamore Creek } \\
\text { near Sunflower }\end{array}$ & 09510150 & 27.1 & 184 & 6.79 & 8,300 & 0 \\
\hline $\begin{array}{l}\text { Wet Bottom Creek } \\
\text { near Childs }\end{array}$ & 09508300 & 14.3 & 93 & 6.51 & 3,410 & 0 \\
\hline $\begin{array}{l}\text { East Verde River } \\
\text { near Childs }\end{array}$ & 09507980 & 62.2 & 276 & 4.44 & 11,000 & 0 \\
\hline $\begin{array}{l}\text { West Clear Creek near } \\
\text { Campe Verde }\end{array}$ & 09505800 & 63.6 & 276 & 4.35 & 13,100 & 11 \\
\hline $\begin{array}{l}\text { Tonto Creek above } \\
\text { Gun Creek }\end{array}$ & 09499000 & 157.9 & 864 & 5.47 & 36,700 & 0 \\
\hline $\begin{array}{r}\text { Cherry Creek } \\
\text { near Globe }\end{array}$ & 09497980 & 35.5 & 199 & 5.60 & 13,000 & 2 \\
\hline $\begin{array}{l}\text { Cibecue Creek near } \\
\text { Chrysotile }\end{array}$ & 09497800 & 45.5 & 139 & 3.07 & 4,930 & 4.1 \\
\hline
\end{tabular}
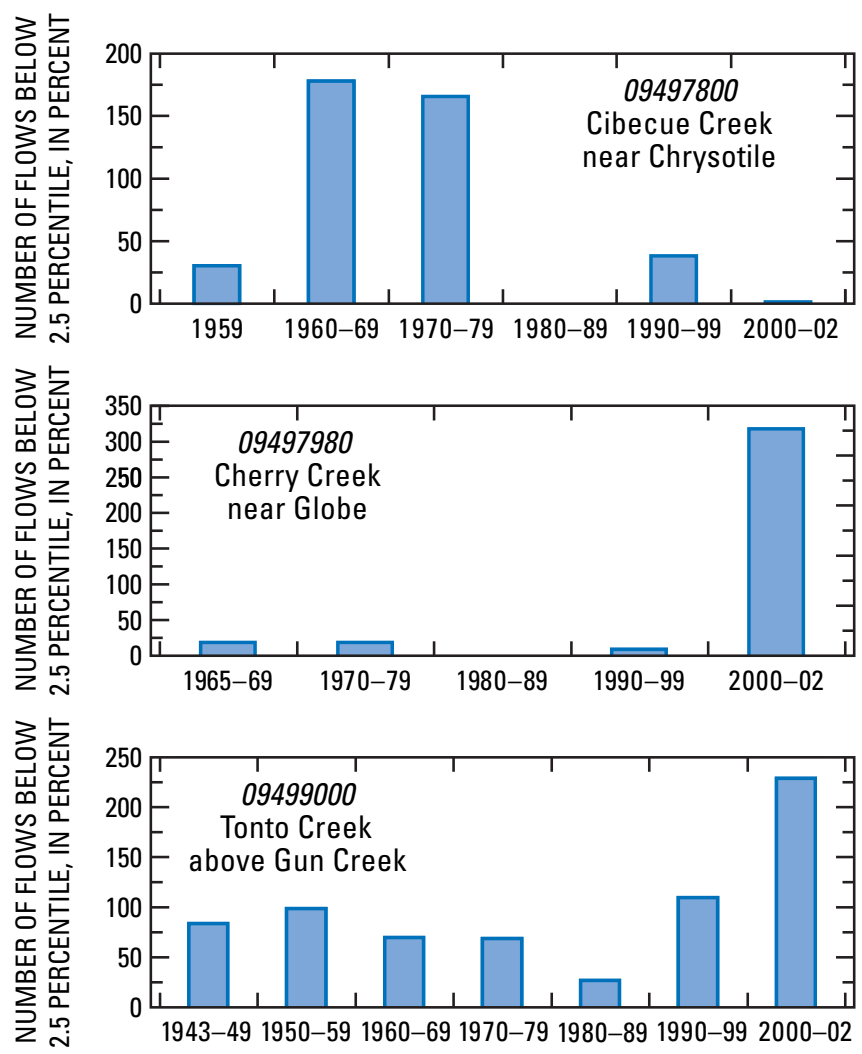

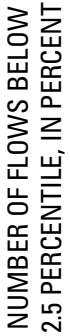

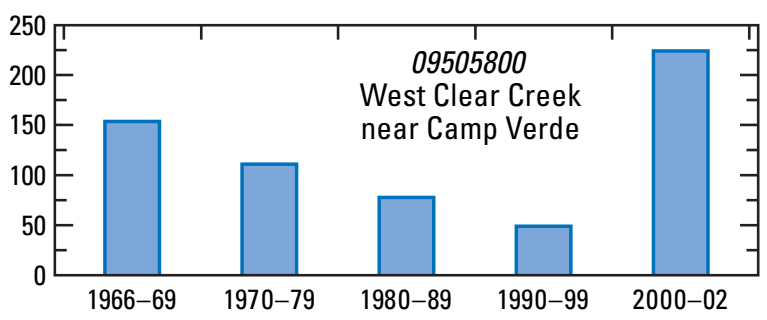

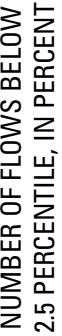

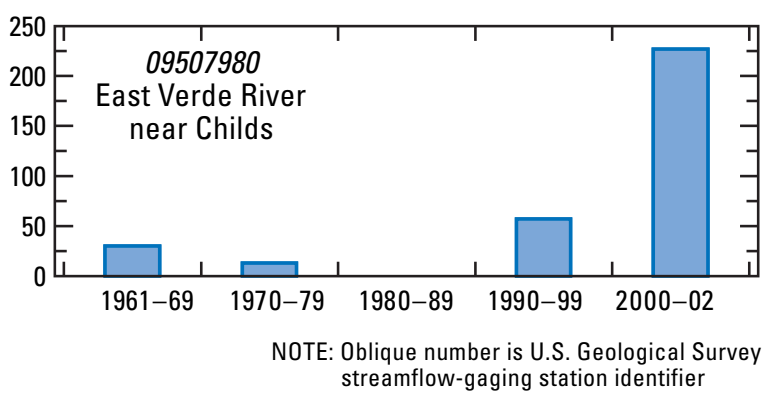

Figure 11. Lowest flows on selected perennial streams in the Mogollon Highlands, central Arizona. 
Runoff was separated from base flow by constructing flow-duration curves (fig. 12) and choosing the value at the break in the upper slope of the curve as the boundary between base flow and runoff. That point is close to the 80th percentile of flows for all streams in the study area. The total stream volume was then calculated for base flow by truncating the daily values at the 80th percentile. For most major streams, base flow is about 30 percent of the total flow volume (fig. 13). Only Canyon Creek, for which records were extended by regression, and Cibecue Creek show significant deviation from that relation. Indeed, Cibecue Creek shows more than half of its total stream volume resulting from base flow. The degree to which Cibecue Creek is distinguished from other streams in its low-flow history (fig. 11), the relative high discharge at the 2.5 percentile (table 3 ), and the large contribution of base flow to total flow (fig. 13) indicate that its hydrologic regimen is affected by unique watershed characteristics, most likely geologic structure.

\section{Ground Water}

The Mogollon Highlands has a complex and incompletely integrated ground-water flow system, which is the product of its diverse topography and geologic history and heterogeneity. It is characterized by multiple and divergent ground-water flow paths, disconnected recharge areas, and multiple water-bearing zones beneath sedimentary and igneous rocks. Analysis of spring and well data and their relation to geology and climate are the primary methods used here to better understand the ground-water system of the area.

\section{Springs}

Springs are intersections of the ground-water flow system with the land surface and thus provide a glimpse of that system. USGS databases contain information for about 73 springs within the study area; there are many other springs shown on USGS topographic maps and USDA Forest Service maps for which no information is available in USGS databases (fig. 14). Most springs in the study area issue from sedimentary rocks along the face of the Mogollon Rim, but because of pervasive fractureinduced secondary permeability, springs occur in almost all rock types within the study area. In this report, springs are referred to either by their spring name as it appears in the USGS database or on topographic maps; or, when a spring is unnamed, by its station name, which uses the same coding as the well-station code system.

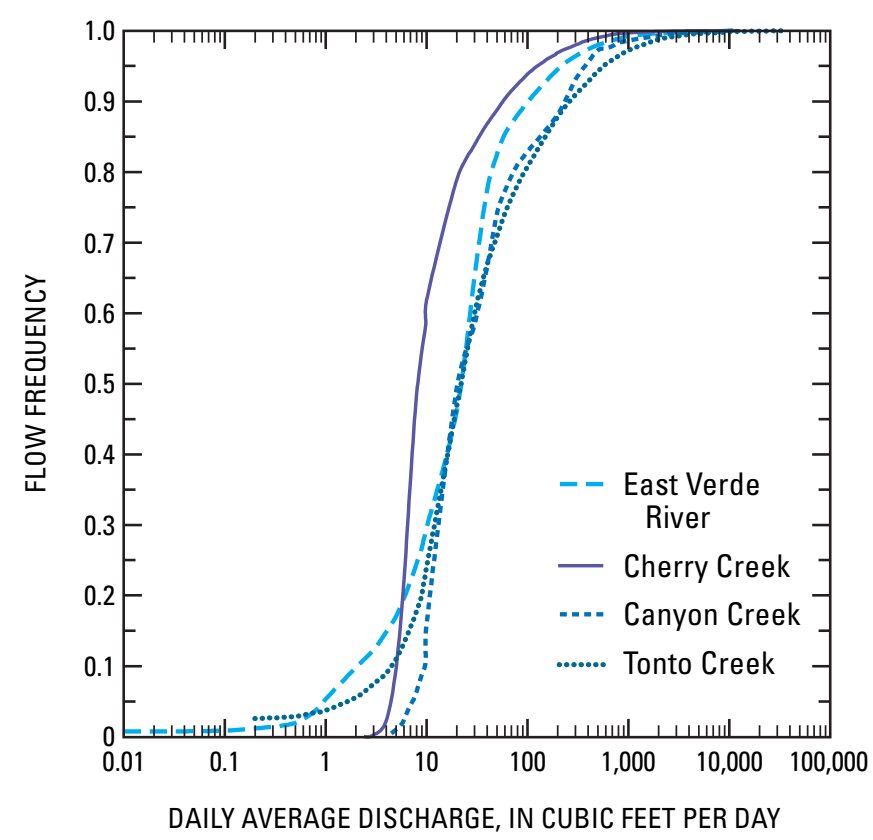

Figure 12. Flow duration curve for selected streams in the Mogollon Highlands, central Arizona.

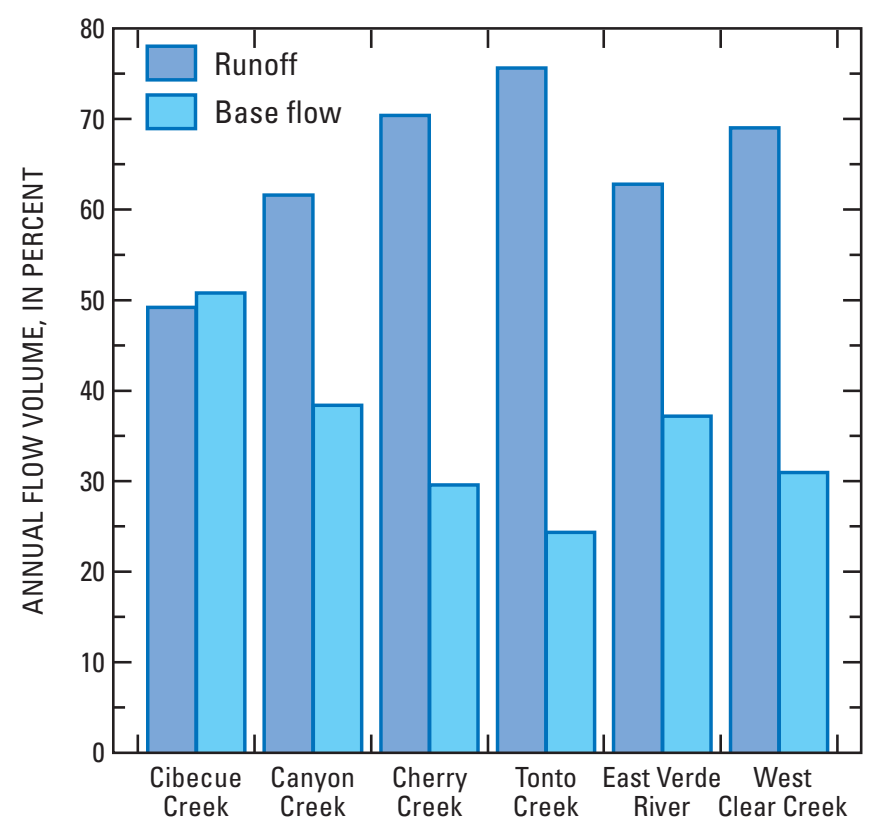

Figure 13. Runoff and base-flow components of selected streams in the Mogollon Highlands, central Arizona. 


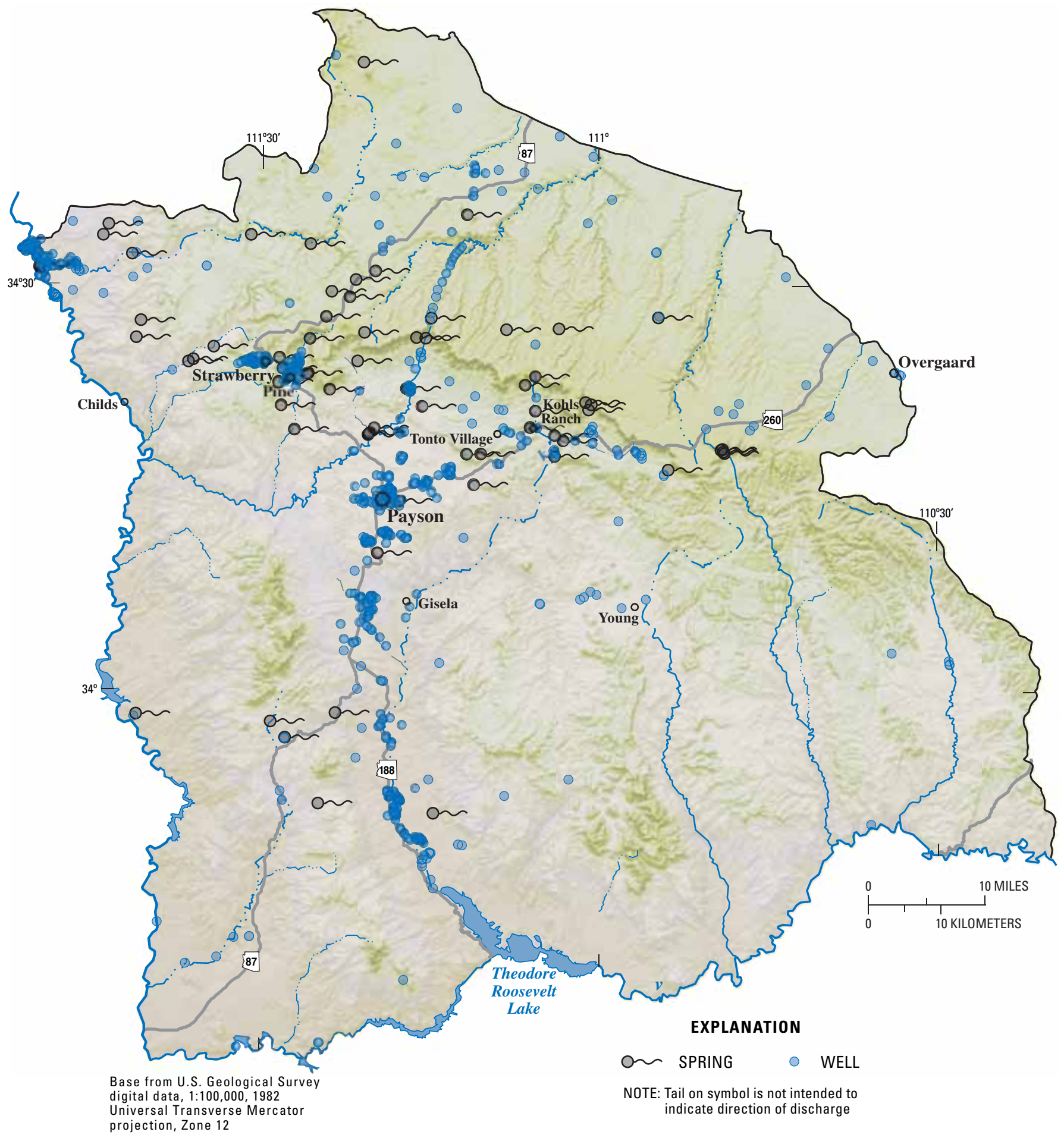

Figure 14. Distribution of springs and wells in the Mogollon Highlands, central Arizona. 
Springs of the Mogollon Highlands have been little studied since Feth and Hem (1963). Of the 46 discharge values recorded in the USGS databases, more than half are estimates or anecdotal reports. Most of the values were recorded before 1960, and until this study no values had been added to the database since 1981. Furthermore, at only a few springs has flow been measured, estimated, or reported more than once in the nearly 60 years of record. Consequently, there exists almost no record of flow variability.

That spring flow can be highly variable is illustrated by the differences between discharges measured in this study and the historic values (table 4). There are several causes for such variability. Measurement of spring flow is subject to large error if it cannot be measured directly at the spring outlet or if all the flow cannot be forced through a flume or into containers for volumetric measurements. During attempts in this study at measuring flow volumetrically from See Spring (table 4 and fig. 15, no. 61) that discharged from numerous points in a bouldery stream terrace, as much as 25 percent of the flow could not be channeled into the containers being used. If terrain difficulties prevent measurement directly from the spring's discharge point, the discharge is typically measured by using a current meter in the stream at some point downstream from the spring, the distance of which depends on the location of a satisfactory control reach for making the measurement. The farther down-stream the measurement is made, the greater the opportunity for the measurement to be affected by losses or gains in the channel reach. Such measurements may also include a significant runoff component in the measured flow. Flow from many springs is also affected by recent precipitation or snowmelt, so single measurements are not likely to provide an accurate characterization of long-term spring conditions.

Table 4. Discharge values for springs in the Mogollon Highlands, central Arizona

[gal/min, gallons per minute; ac-ft/yr, acre-feet per year. Method codes: V, volumetric; O, observation; E, estimated; F, flume; R, reported; C, current meter; $\mathrm{G}$, gaged. Other data available codes: I, isotope; $\mathrm{C}$, chemical. ***, unknown]

\begin{tabular}{|c|c|c|c|c|c|c|}
\hline $\begin{array}{l}\text { Map code }{ }^{1} \\
\text { (see fig. 15) }\end{array}$ & Spring or station name & $\begin{array}{c}\text { Discharge } \\
\text { (gal/min) }\end{array}$ & Discharge year & Method & $\begin{array}{c}\text { Annual } \\
\text { discharge } \\
\text { (ac-ft/yr) }\end{array}$ & $\begin{array}{c}\text { Other data } \\
\text { available }^{8,9}\end{array}$ \\
\hline 36 & Lee Johnson & .00 & 2002 & $\mathrm{O}$ & .00 & \\
\hline 17 & Cottonwood & .25 & 1946 & $\mathrm{E}$ & .40 & \\
\hline 24 & A-12-09 30DDC2 & .25 & 1946 & $\mathrm{E}$ & .40 & \\
\hline 16 & A-07-08 12CDA & .50 & 1976 & V & .81 & \\
\hline 21 & A-07-09 19AAB & .93 & 1976 & V & 1.50 & \\
\hline 49 & Winters NO 1 & 1.00 & 1952 & $\mathrm{E}$ & 1.61 & \\
\hline 7 & A-14-06 29DAD & 1.00 & 1981 & $\mathrm{E}$ & 1.61 & \\
\hline 9 & Hackberry & 2.00 & 1977 & V & 3.23 & \\
\hline 19 & A-11H09 30DCB & 3.00 & 1946 & $\mathrm{E}$ & 4.84 & \\
\hline 28 & Red Rock & 3.00 & 1946 & $\mathrm{E}$ & 4.84 & \\
\hline 28 & Red Rock & .50 & 2001 & $\mathrm{~V}^{2}$ & .81 & I \\
\hline 28 & Red Rock & .32 & 2002 & $\mathrm{~V}^{2}$ & .51 & \\
\hline
\end{tabular}

See footnotes at end of table. 


\section{Hydrology of the Mogollon Highlands, Central Arizona}

Table 4. Discharge values for springs in Mogollon Highlands, central Arizona-Continued

\begin{tabular}{|c|c|c|c|c|c|c|}
\hline $\begin{array}{l}\text { Map code }^{1} \\
\text { (see fig. 15) }\end{array}$ & Spring or station name & $\begin{array}{c}\text { Discharge } \\
\text { (gal/min) }\end{array}$ & Discharge year & Method & $\begin{array}{c}\text { Annual } \\
\text { discharge } \\
\text { (ac-ft/yr) }\end{array}$ & $\begin{array}{c}\text { Other data } \\
\text { available }^{8,9}\end{array}$ \\
\hline 40 & Blue Spring south & 4.00 & 1952 & $\bar{E}$ & 6.46 & \\
\hline 54 & Bear Flat & 4.00 & 1975 & V & 6.46 & $\mathrm{C}$ \\
\hline 41 & Turkey (south) & 5.00 & 1952 & $\mathrm{E}$ & 8.07 & \\
\hline 12 & A-12-07 22C UNSURV & 5.00 & 1978 & $\mathrm{E}$ & 8.07 & $\mathrm{C}$ \\
\hline 8 & Bull Pen & 7.00 & 1959 & $\mathrm{E}$ & 11.3 & \\
\hline 63 & Allenbaugh & 8.00 & 2001 & $\mathrm{~V}^{2}$ & 12.9 & I \\
\hline 63 & Allenbaugh & .00 & 2002 & $\mathrm{O}$ & .00 & \\
\hline 53 & Bootleg & 8.00 & 2001 & $\mathrm{~V}^{2}$ & 12.9 & I \\
\hline 53 & Bootleg & 5.00 & 2002 & $\mathrm{~V}^{2}$ & 8.07 & \\
\hline 26 & A-12-09 08CCD & 10.0 & 1946 & $\mathrm{E}$ & 16.1 & \\
\hline 3 & A-13-05 16BBD2 & 13.0 & 1980 & E & 21.0 & \\
\hline 35 & Geronimo & 14.0 & 2001 & $\mathrm{~F}^{2}$ & 22.6 & $\mathrm{C}, \mathrm{I}$ \\
\hline 60 & A-11-13 18AA & 15.0 & 1966 & $\mathrm{E}$ & 24.2 & \\
\hline 34 & Clover & 20.0 & 1952 & $\mathrm{E}$ & 32.3 & \\
\hline 2 & Catfish & 22.0 & 1981 & $\mathrm{~V}$ & 35.5 & \\
\hline 47 & Wildcat & 58.5 & 1952 & $\mathrm{R}^{3}$ & 94 & \\
\hline 51 & Henturkey & 60.0 & 1952 & $\mathrm{C}$ & 97 & \\
\hline 59 & Nappa & 70.0 & 1966 & $\mathrm{C}$ & 113 & I \\
\hline 42 & A-11H10 24BCA & 75.0 & 1952 & $\mathrm{E}$ & 121 & $\mathrm{C}$ \\
\hline 4 & A-13-05 16BBD1 & 90.0 & 1980 & $\mathrm{E}$ & 145 & \\
\hline 50 & Indian Gardens & 100 & 1952 & $\mathrm{R}^{3}$ & 102 & \\
\hline 50 & Indian Gardens & 57.5 & 2001 & $\mathrm{~V} / \mathrm{F}^{2,4}$ & 93 & $\mathrm{C}, \mathrm{I}$ \\
\hline 50 & Indian Gardens & 26.5 & 2002 & $\mathrm{~F}^{2}$ & 43 & \\
\hline 27 & Bear & 100 & 1959 & $\mathrm{E}$ & 161 & $\mathrm{C}$ \\
\hline 45 & Pieper Hatchery & 125 & 1952 & $\mathrm{E}$ & 202 & \\
\hline 37 & Big & 175 & 1952 & $\mathrm{C}$ & 282 & $\mathrm{C}$ \\
\hline 37 & Big & 100 & 1952 & $\mathrm{R}^{3}$ & 161 & \\
\hline 65 & A-11-14 35DBA1 & 310 & $* * *$ & $\mathrm{C}$ & 500 & \\
\hline 38 & The Grotto & 340 & 1952 & $\mathrm{C}$ & 549 & \\
\hline 38 & The Grotto & 10 & 1952 & $\mathrm{R}^{3}$ & 16 & \\
\hline 66 & A-11-14 35DBA2 & 410 & $* * *$ & $\mathrm{C}$ & 662 & \\
\hline 64 & A-11-14 35DBB & 480 & $* * *$ & $\mathrm{C}$ & 775 & \\
\hline 58 & $\mathrm{R}-\mathrm{C}$ & 800 & 1952 & $\mathrm{E}$ & 1,291 & $\mathrm{C}$ \\
\hline 22 & Tonto Natural Bridge & 841 & 2002 & $\mathrm{G}^{5}$ & 1,357 & $\mathrm{C}, \mathrm{I}$ \\
\hline 61 & See & 900 & 1966 & $\mathrm{E}$ & 1,453 & \\
\hline 61 & See & 104 & 2001 & $\mathrm{~V}^{2}$ & 168 & \\
\hline 61 & See & 84 & 2002 & $\mathrm{~V}^{2}$ & 136 & $\mathrm{C}, \mathrm{I}$ \\
\hline
\end{tabular}


Table 4. Discharge values for springs in Mogollon Highlands, central Arizona-Continued

\begin{tabular}{|c|c|c|c|c|c|c|}
\hline $\begin{array}{l}\text { Map code }^{1} \\
\text { (see fig. 15) }\end{array}$ & Spring or station name & $\begin{array}{c}\text { Discharge } \\
\text { (gal/min) }\end{array}$ & Discharge year & Method & $\begin{array}{c}\text { Annual } \\
\text { discharge } \\
\text { (ac-ft/yr) }\end{array}$ & $\begin{array}{c}\text { Other data } \\
\text { available }\end{array}$ \\
\hline 15 & Buckhorn & 1,000 & 1959 & $\bar{E}$ & 1,614 & $\mathrm{C}$ \\
\hline 56 & Horton & 1,100 & 2002 & $\mathrm{C}^{2}$ & 1,776 & C,I \\
\hline 52 & Tonto & 1,291 & 2001 & $\mathrm{~F}^{6}$ & 2,084 & $\mathrm{C}, \mathrm{I}$ \\
\hline 39 & Webber & 1,300 & 1952 & $\mathrm{~F}$ & 2,082 & \\
\hline 39 & Webber & 1,570 & 2001 & $\mathrm{C}^{2}$ & 2,534 & $\mathrm{C}, \mathrm{I}$ \\
\hline 39 & Webber & 996 & 2002 & $\mathrm{~F}^{2}$ & 1,608 & \\
\hline 67 & Canyon & 2,224 & 2001 & $\mathrm{~F}^{6}$ & 3,590 & \\
\hline 44 & Cold & 4,200 & 1952 & $\mathrm{C}$ & 6,779 & \\
\hline 44 & Cold & 1,060 & 1952 & $\mathrm{R}^{3}$ & 1,711 & \\
\hline 44 & Cold & 830 & 1952 & $\mathrm{R}^{3}$ & 1,340 & \\
\hline 14 & Fossil & 21,647 & 2001 & $\mathrm{C}^{7}$ & 34,941 & $\mathrm{C}, \mathrm{I}$ \\
\hline
\end{tabular}

${ }^{1}$ Map code " 1 " not used.

${ }^{2}$ Measured during this study.

${ }^{3}$ Published in Feth and Hem (1963). Method not known.

${ }^{4}$ At higher flows, discharge emanates from two outlets that require different measurement methods.

${ }^{5}$ Mean of once-daily stage measurements from May 2001 through September 2002, Arizona State Parks.

${ }^{6}$ Mean of once-monthly flume measurements in fish hatcheries from January 1980 through May 2001, Arizona Game and Fish Department.

${ }^{7}$ Mean of various measurements made from 1946 through 2001. Sources include Feth and Hem (1963); U.S. Department of Agriculture, Forest Service (Tonto National Forest); U.S. Geological Survey.

${ }^{8}$ See table 7 for chemical data.

${ }^{9}$ See tables 10 and 11 for isotope data. 


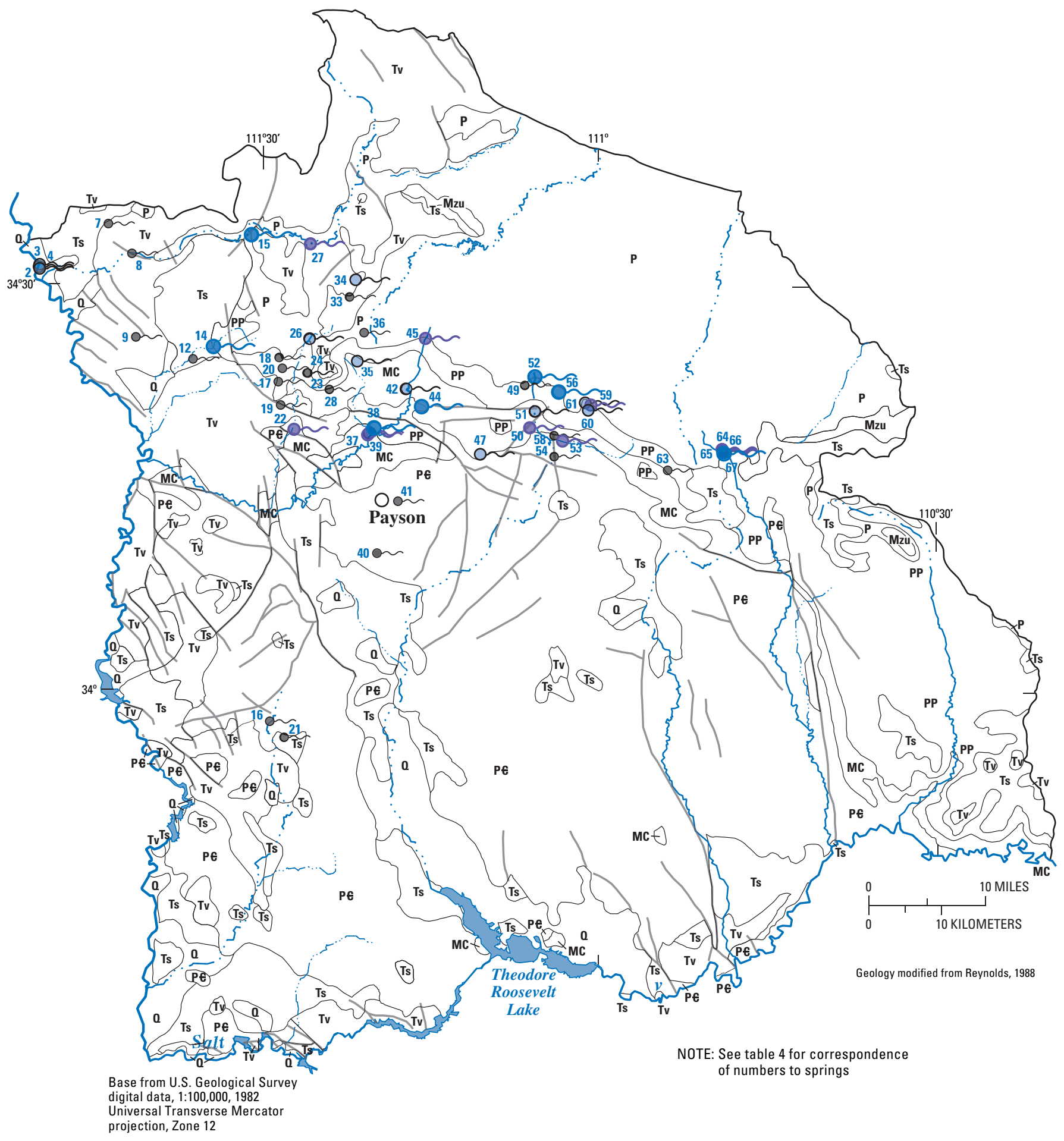

Figure 15. Geology, geologic structure, and locations of springs for which discharge records are available, Mogollon Highlands, central Arizona. 


\section{EXPLANATION}

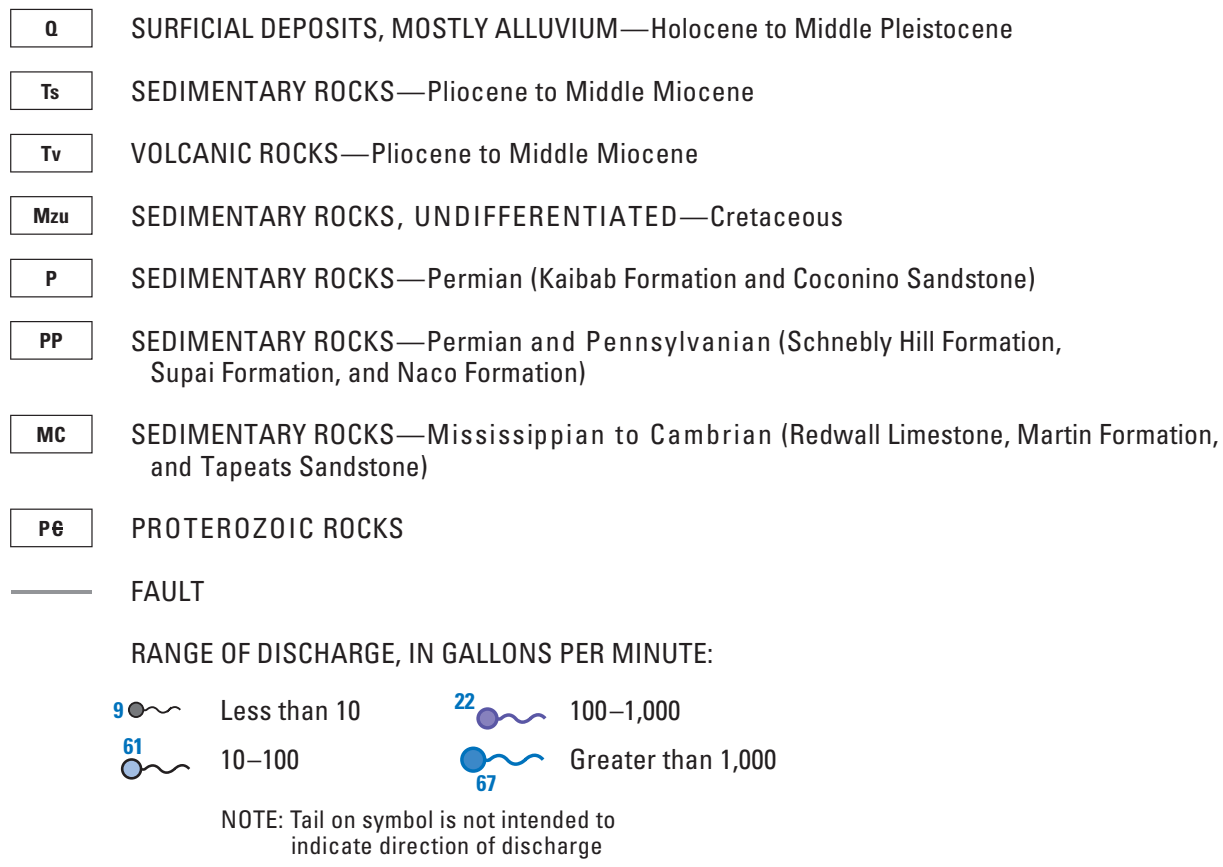

Figure 15. Continued.

For the most part, spring discharge measurements have been too few to allow meaningful statistical comparisons. Multiple discharge measurements are available, however, for four major springs. The Arizona Game and Fish Department operates hatcheries in the headwaters of Tonto and Canyon Creeks and has measured spring discharges monthly since 1980 (fig. 16A). Arizona State Parks has monitored flow in Pine Creek in Tonto Natural Bridge State Park once a day since May 2001. During base-flow conditions, most flow comes from Tonto Natural Bridge Spring (fig. 16B; Robert Sejkora, water program manager, Arizona State Parks, oral commun., 2003). Tonto National Forest collected 16 discharge measurements of flow in Fossil Creek below the springs between November 1999 and April 2001; measurements made above the springs showed that almost all flow was accounted for by discharge from the springs (fig. 16C). All these springs show fairly consistent minimum flows during the period of record and some spikes during periods of runoff. Canyon Spring is the only monitored spring to show a significant change in base flow over time-a decline of about 1,000 gal/min in average flow between 1992 and
1994 that has continued to the end of the period of record. Statistical summaries of discharge from the four springs shows them to be characterized by low variability and a generally narrow range of values (table 5).

Nearly half of all spring discharges recorded are below $10 \mathrm{gal} / \mathrm{min}$ (figs. 15 and 17). On the basis of inspection of several springs in the area, most that have never been measured probably do not exceed $10 \mathrm{gal} / \mathrm{min}$, and during drought conditions, many are dry. A few springs account for almost all of the spring discharge in the Mogollon Highlands; indeed, the average discharge of 20,345 gal/min at Fossil Springs is greater than the total average discharge of all other springs in the study area (figs. 16 and 17). Despite their relative insignificance in the total water budget of the Mogollon Highlands, low-discharge springs do provide evidence of the hydrologic characteristics of the various waterbearing zones from which they discharge, and they also are of local environmental significance, providing moisture for meadowlands, riparian vegetation, and aquatic and wildlife habitat. 


\section{Hydrology of the Mogollon Highlands, Central Arizona}

A. Tonto Spring and Canyon Spring fish hatcheries - Data from Arizona Game and Fish Department

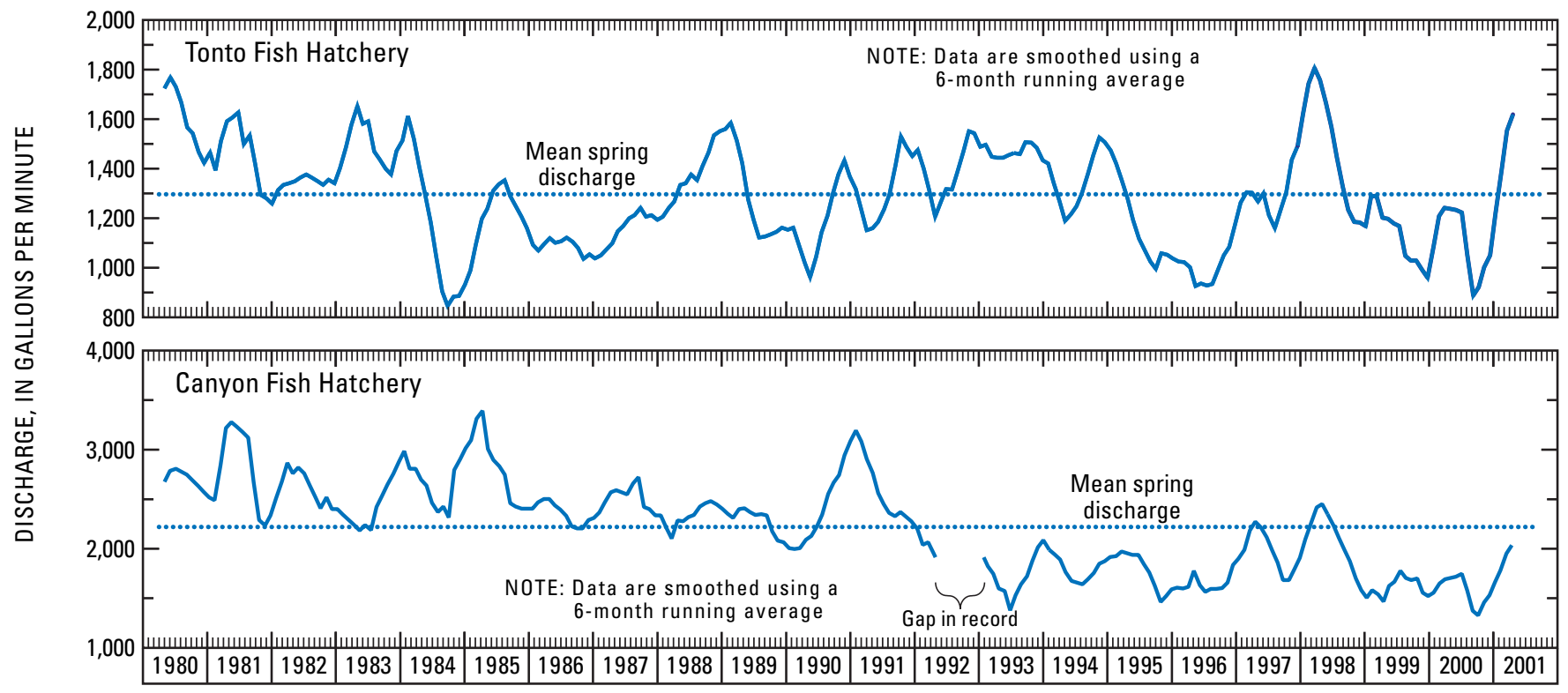

B. Pine Creek below Tonto Natural Bridge Spring — Data from Arizona State Parks

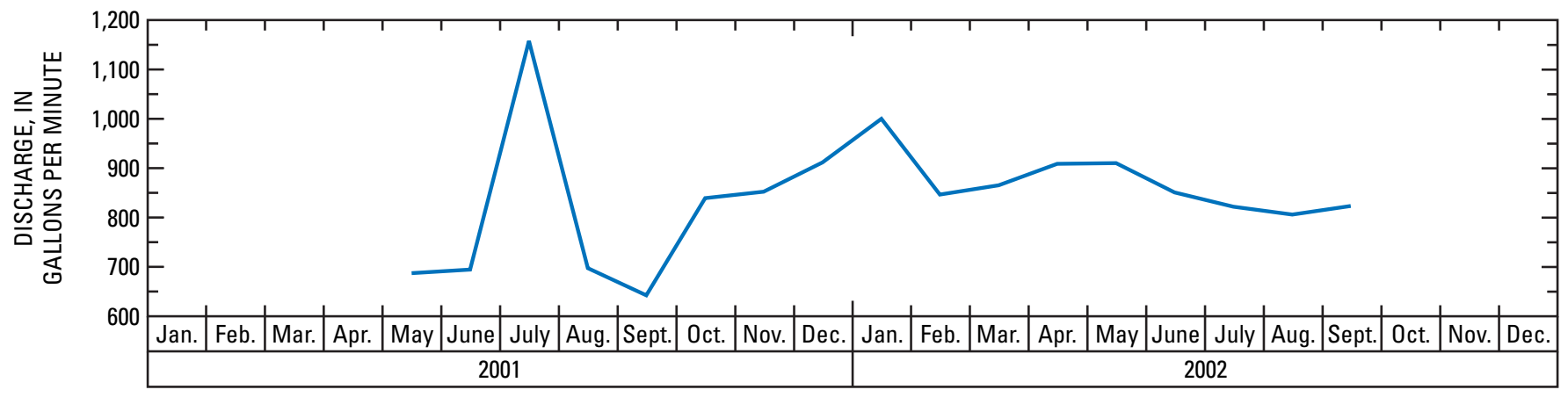

C. Fossil Springs in Fossil Creek—Data from U.S. Department of Agriculture Forest Service, Tonto National Forest

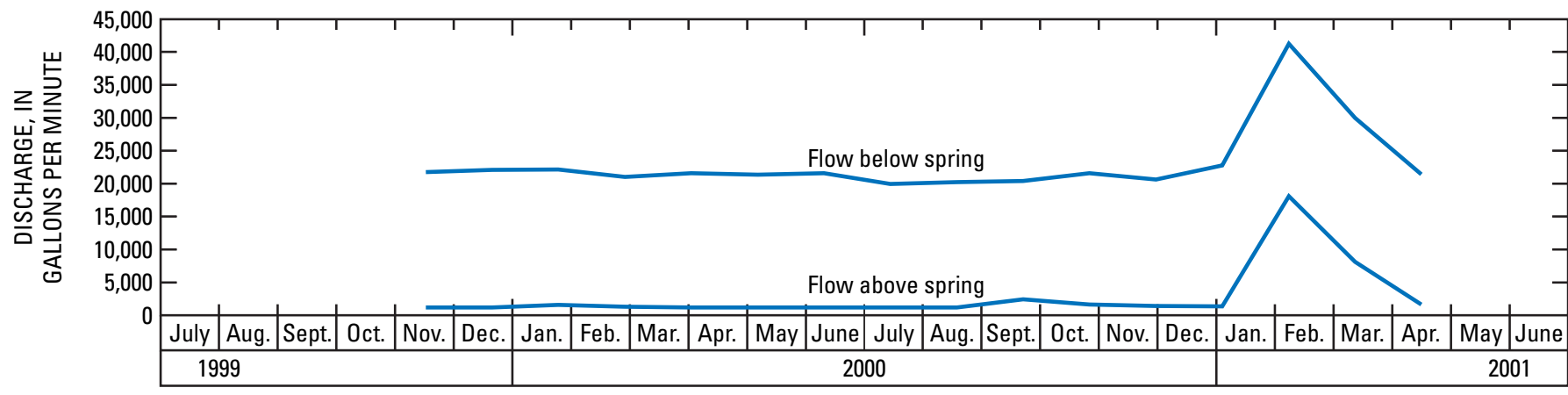

Figure 16. Discharge of springs for which repeated measurements are available, Mogollon Highlands, central Arizona: $A$, Spring discharge measured at fish hatcheries once a month; $B$, Discharge measured once daily in Pine Creek below Tonto Natural Bridge Spring; $C$, Discharge from intermittent current-meter measurements in Fossil Creek above and below springs. 
Table 5. Statistical summary of discharge values for monitored springs, Mogollon Highlands, central Arizona

[Discharge values are in gallons per minute. Coefficient of variation is the standard deviation divided by the mean]

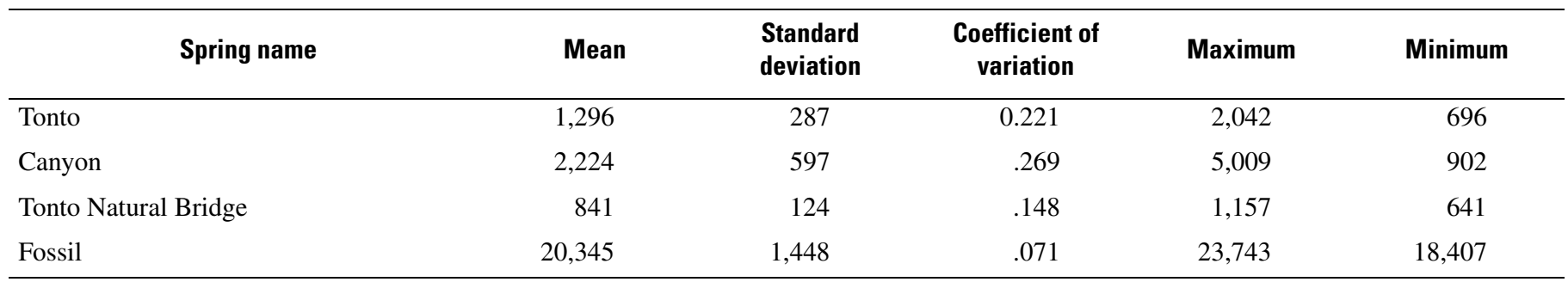

A. Percentage of total springs by range of discharge

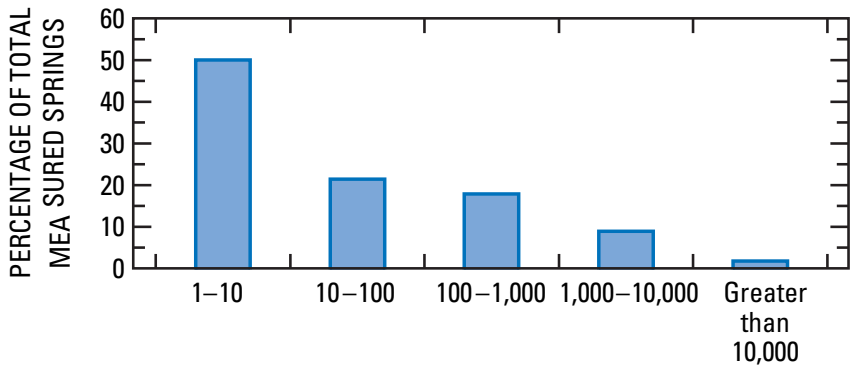

RANGE OF DISCHARGE, IN GALLONS PER MINUTE

$B$. Percentage of total spring discharge by range of discharge

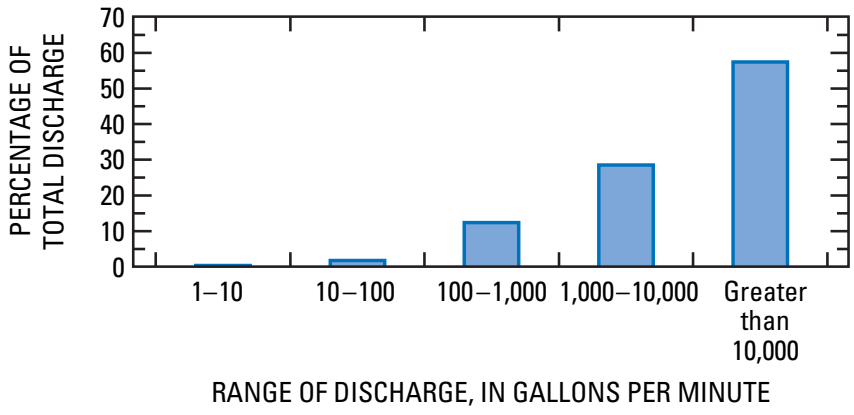

Figure 17. A, Percentage of total springs by range of discharge; $B$, Percentage of total spring discharge by range of discharge, Mogollon Highlands, central Arizona.

With the exception of Buckhorn Spring (table 4 and fig. 15, no. 15), springs having a discharge greater than $100 \mathrm{gal} / \mathrm{min}$ issue from carbonate rocks or just below carbonate rocks. Buckhorn Spring, which has a recorded discharge of $1,000 \mathrm{gal} / \mathrm{min}$, issues from Coconino Sandstone beneath a layer of volcanic rocks in West Clear Creek on the Colorado Plateau. A cluster of springs, from Pieper Hatchery Spring (table 4 and fig. 15, no. 45) on the west in the East Verde River drainage to Canyon Spring (table 4 and fig. 15, no. 67) above Canyon Creek on the east, discharge from the Fort Apache Member of the Schnebly Hill Formation.
These are the stratigraphically and topographically highest springs on the face of the Mogollon Rim. Most other large carbonate springs are in the East Verde River drainage where they discharge from the lower Paleozoic rocks of the Redwall Limestone or the Martin Formation, or at Tonto Natural Bridge Spring, from the base of the Paleozoic rocks where the Tapeats Sandstone overlies Proterozoic rocks. Fossil Springs discharges from near the contact between the Naco Formation and the Redwall Limestone. High-discharge carbonate springs tend to be where linear features mapped by Gettings and Bultman (geologists, U.S. Geological Survey, written commun., 2003) converge, suggesting that such springs occur at the intersection of large scale structural features indicated by geophysical properties, maps, and remotely sensed data.

\section{Wells}

About 750 wells within the study area are registered with the State of Arizona (fig. 14). Many of these wells are clustered around the communities of Payson and Pine-Strawberry, as well as in the northwestern corner of the study area on the outskirts of Camp Verde. There is also a high density of wells along the valley of lower Tonto Creek, and another string of wells parallels an aqueduct above the Mogollon Rim. The remainder of the 750 wells are sparsely scattered throughout the study area (fig. 14).

Although well data are important for analysis of a ground-water system, there is no information in USGS databases for most wells in the study area. Furthermore, the usefulness of the well data are limited by their patchy geographic distribution, few repeated water-level measurements, and the small percentage of wells for which discharge, aquifer characteristics, and hydrogeologic information were recorded. In 1979, the ADWR assumed the ground-water monitoring program from the USGS in Arizona; and in 1982, it merged its database 


\section{Hydrology of the Mogollon Highlands, Central Arizona}

with the USGS database (W.H. Remick, hydrologist, Arizona Department of Water Resources, written commun., 2003).

From the 1950 s to 2003 , nearly 2,600 water-level altitudes were recorded for 522 wells; however, several anecdotal reports, especially before 1975, are problematic (table 6). Water-level reporting has been sporadic with most measurements recorded during the 1970s and 1980s, and a decline in the number of measurements after 1990. The ADWR measures water levels quarterly in 16 index wells in the Payson and Pine-Strawberry areas (table 6 and fig. 18, insets B and C). The town of Payson has conducted extensive monitoring of water levels in its production wells since at least the mid-1990s (fig. 18, inset C).

Most water levels reflect depths to water of less than $100 \mathrm{ft}$ and all but about 40 values are less than $300 \mathrm{ft}$. All but six wells in the USGS database having water-level depths of more than $300 \mathrm{ft}$ are on the Colorado Plateau. Although water levels typically are given for production levels, well logs, especially for deeper wells, frequently describe multiple water-bearing zones, and dry wells are not uncommon (Southwest Ground-water Consultants, Inc., 1998; AGRA Earth and Environmental, Inc., 1999; Weitzman, 2002).

Table 6. Selected wells for which water-level data are available, Mogollon Highlands, central Arizona

[In "Notes" column, 1 indicates water-chemistry data are available in table 8, and 2 indicates an Arizona Department of Water Resources index well]

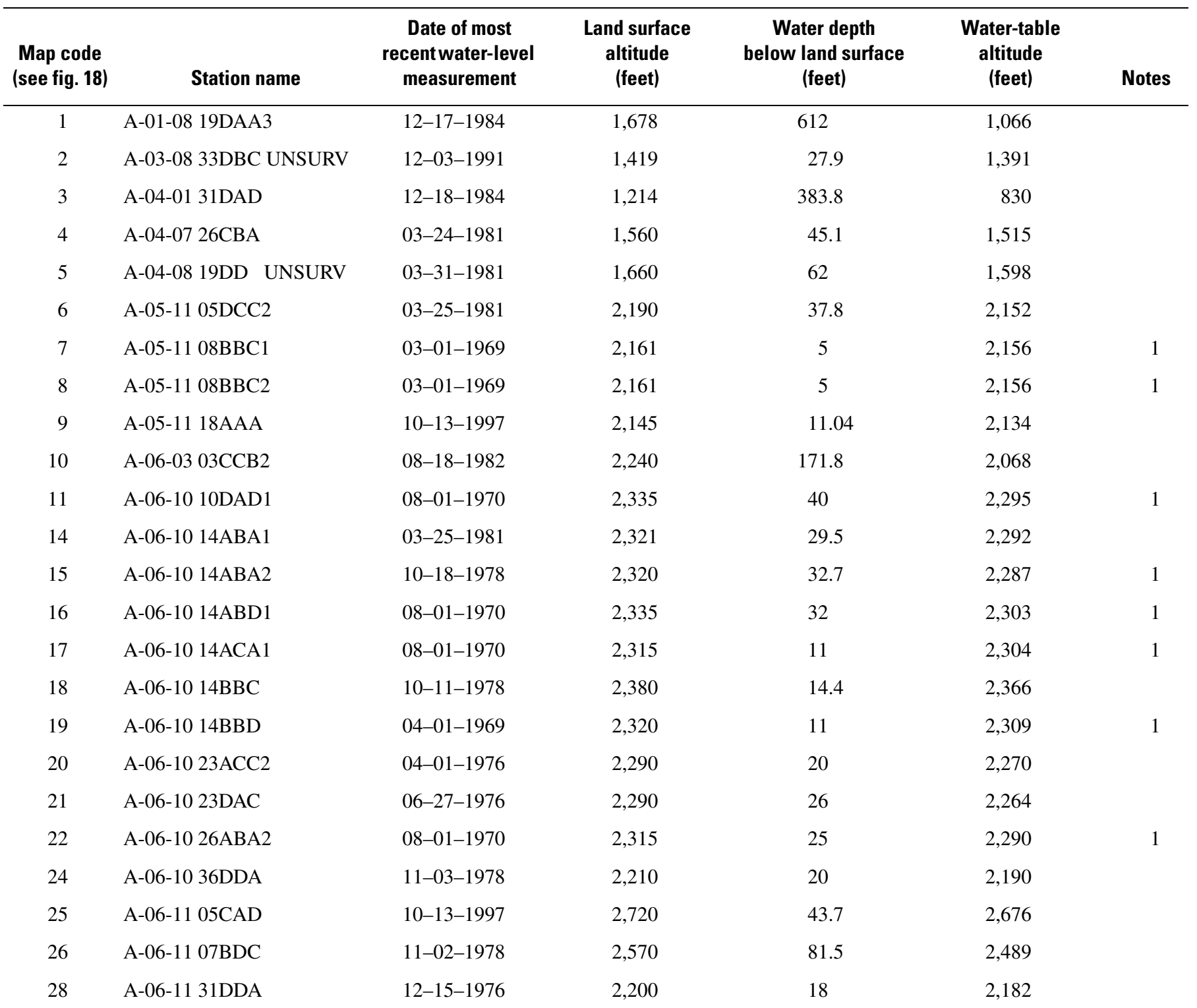


Table 6. Selected wells for which water level data are available, Mogollon Highlands, central Arizona—Continued

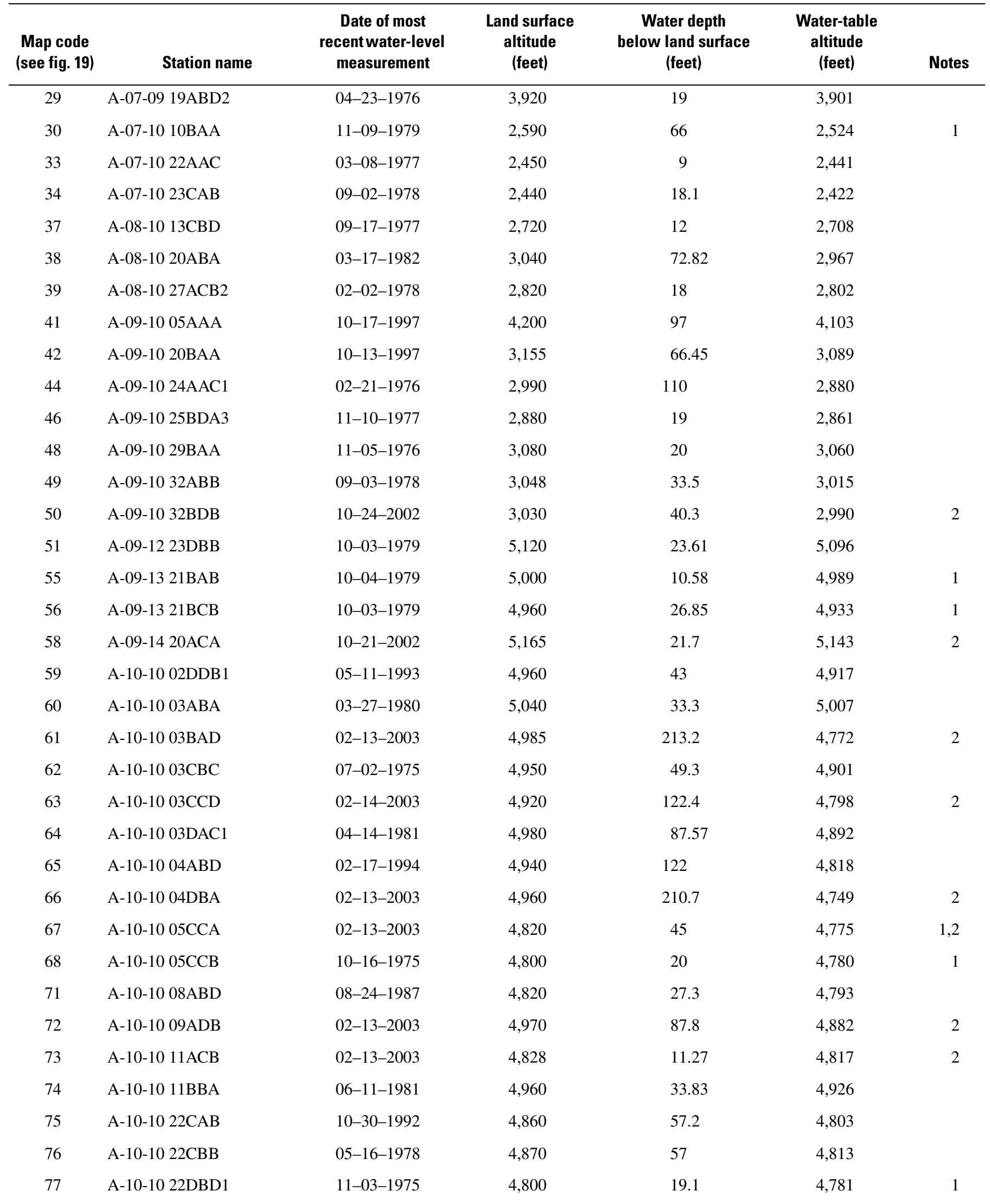




\section{Hydrology of the Mogollon Highlands, Central Arizona}

Table 6. Selected wells for which water level data are available, Mogollon Highlands, central Arizona—Continued

\begin{tabular}{|c|c|c|c|c|c|c|}
\hline $\begin{array}{c}\text { Map code } \\
\text { (see fig. 19) }\end{array}$ & Station name & $\begin{array}{l}\text { Date of most } \\
\text { recent water-level } \\
\text { measurement }\end{array}$ & $\begin{array}{l}\text { Land surface } \\
\text { altitude } \\
\text { (feet) }\end{array}$ & $\begin{array}{l}\text { Water depth } \\
\text { below land surface } \\
\text { (feet) }\end{array}$ & $\begin{array}{l}\text { Water-table } \\
\text { altitude } \\
\text { (feet) }\end{array}$ & Notes \\
\hline 78 & A-10-10 22DCA2 & 10-30-1984 & 4,840 & 44.01 & 4,796 & \\
\hline 79 & A-10-10 23DDB & 08-19-1992 & 4,700 & 26.4 & 4,674 & \\
\hline 80 & A-10-10 25BBA & 10-30-1992 & 4,650 & 20.7 & 4,629 & \\
\hline 81 & A-10-10 27CAA & 11-19-1993 & 4,760 & 19.2 & 4,741 & \\
\hline 82 & A-10-10 28BCA1 & 10-25-1979 & 4,630 & 18 & 4,612 & 1 \\
\hline 83 & A-10-10 28BCA2 & $10-25-1979$ & 4,650 & 25 & 4,625 & 1 \\
\hline 84 & A-10-10 28BCC2 & 06-02-1988 & 4,690 & 112.5 & 4,578 & \\
\hline 85 & A-10-10 28BCD1 & $10-25-1979$ & 4,640 & 28.9 & 4,611 & 1 \\
\hline 87 & A-10-10 29ADD & 03-01-1976 & 4,700 & 22 & 4,678 & \\
\hline 88 & A-10-11 05BAD & 07-17-1975 & 4,600 & 7.8 & 4,592 & 1 \\
\hline 90 & A-10H12 19DAD & 07-17-1975 & 5,270 & 10 & 5,260 & 1 \\
\hline 92 & A-10H14 20BAC & 09-24-1979 & 6,180 & 14.44 & 6,166 & 1 \\
\hline 93 & A-10H14 27CBD & 09-25-1979 & 6,200 & 45 & 6,155 & 1 \\
\hline 94 & A-10H14 27CCB & 09-25-1979 & 6,550 & 41.45 & 6,509 & \\
\hline 95 & A-11-10 11AAA1 & 08-05-1975 & 4,920 & 212.6 & 4,707 & \\
\hline 97 & A-11-10 23AAD1 & 07-01-1975 & 5,180 & 236 & 4,944 & \\
\hline 99 & A-11-10 23ACA & 07-01-1975 & 5,150 & 134 & 5,016 & 1 \\
\hline 101 & A-11-10 27CCB & 02-13-2003 & 5,000 & 159.2 & 4,841 & 1,2 \\
\hline 102 & A-11-10 27DDB & 02-17-1994 & 5,052 & 84.7 & 4,967 & \\
\hline 103 & A-11-10 28DBD & 07-02-1975 & 5,040 & 190 & 4,850 & \\
\hline 104 & A-11-10 31DAC & 11-05-2002 & 5,060 & 176.3 & 4,884 & 2 \\
\hline 105 & A-11-10 32ACD & 02-13-2003 & 5,140 & 342 & 4,798 & 1,2 \\
\hline 106 & A-11-10 34ABA & 11-20-1998 & 5,070 & 91 & 4,979 & 2 \\
\hline 107 & A-11-10 35CCC & 02-13-2003 & 5,060 & 129.3 & 4,931 & 2 \\
\hline 108 & A-11-10 36AAA & 07-14-1975 & 4,750 & 20.3 & 4,730 & \\
\hline 109 & A-11-10 36ADD4 & 08-25-1975 & 4,725 & 15 & 4,710 & \\
\hline 110 & A-11-11 27BBB & $08-21-1975$ & 5,050 & 162 & 4,888 & \\
\hline 111 & A-11-11 27BBD & 08-22-1975 & 5,080 & 130.7 & 4,949 & \\
\hline 112 & A-11-11 27BCB1 & 07-16-1975 & 5,040 & 140 & 4,900 & 1 \\
\hline 113 & A-11-11 27CBC & 07-16-1975 & 4,920 & 81 & 4,839 & \\
\hline 115 & A-11-11 31ADC1 & 07-15-1975 & 4,650 & 94.5 & 4,556 & 1 \\
\hline 116 & A-11-11 31CAA & 07-14-1975 & 4,680 & 25.3 & 4,655 & \\
\hline 117 & A-11-11 31DBC & 07-14-1975 & 4,680 & 20 & 4,660 & \\
\hline 118 & A-11-11 32BBC1 & 07-16-1975 & 4,670 & 42.2 & 4,628 & \\
\hline 119 & A-11-11 32CBB & 07-15-1975 & 4,670 & 35 & 4,635 & 1 \\
\hline
\end{tabular}


Table 6. Selected wells for which water level data are available, Mogollon Highlands, central Arizona—Continued

\begin{tabular}{|c|c|c|c|c|c|c|}
\hline $\begin{array}{l}\text { Map code } \\
\text { (see fig. 19) }\end{array}$ & Station name & $\begin{array}{l}\text { Date of most } \\
\text { recent water-level } \\
\text { measurement }\end{array}$ & $\begin{array}{l}\text { Land surface } \\
\text { altitude } \\
\text { (feet) }\end{array}$ & $\begin{array}{l}\text { Water depth } \\
\text { below land surface } \\
\text { (feet) }\end{array}$ & $\begin{array}{l}\text { Water-table } \\
\text { altitude } \\
\text { (feet) }\end{array}$ & Notes \\
\hline 120 & A-11-11H05DBC & $12-23-1973$ & 5,800 & 194 & 5,606 & \\
\hline 121 & A-11-11H05DCD & 08-21-1975 & 5,770 & 181.5 & 5,589 & 1 \\
\hline 122 & A-11-11H08AAA & 08-21-1975 & 5,750 & 162 & 5,588 & 1 \\
\hline 124 & A-11-12 04CDC & $07-17-1975$ & 5,800 & 151 & 5,649 & \\
\hline 125 & A-11-12 32BBA & 08-21-1975 & 5,720 & 91.5 & 5,629 & 1 \\
\hline 126 & A-11-12 34ADD2 & 10-14-1979 & 5,000 & 8.2 & 4,992 & \\
\hline 127 & A-11-13 20CCB1 & 10-11-1979 & 5,860 & 18.7 & 5,841 & \\
\hline 128 & A-11-13 29CCD & 05-14-1952 & 5,800 & 14.96 & 5,785 & 1 \\
\hline 129 & A-11-13 30AAB & 05-18-1974 & 5,820 & 58 & 5,762 & 1 \\
\hline 130 & A-11-13 34CBA & 08-23-1975 & 6,165 & 18.6 & 6,146 & 1 \\
\hline 131 & A-11-13 34CBA2 & 10-21-2002 & 6,145 & 148.8 & 5,996 & 2 \\
\hline 132 & A-11-13 35DAD1 & 09-24-1979 & 6,240 & 60.63 & 6,179 & 1 \\
\hline 133 & A-11-13 36CAC & 09-24-1979 & 6,300 & 50 & 6,250 & 1 \\
\hline 135 & A-11-14 13ACA & 06-14-1966 & 7,555 & 403 & 7,152 & \\
\hline 136 & A-11-14 14BAB & 08-01-1959 & 7,500 & 435 & 7,065 & 1 \\
\hline 137 & A-11-14 22CBD & 08-09-1966 & 7,575 & 680 & 6,895 & 1 \\
\hline 139 & A-11-15 20BDC & 06-14-1966 & 7,550 & 696.6 & 6,853 & \\
\hline 140 & A-11-16 20ADB2 & 06-01-1973 & 6,865 & 410 & 6,455 & \\
\hline 143 & A-11H11 35BBB & 07-17-1975 & 5,510 & 123.4 & 5,387 & 1 \\
\hline 144 & $\mathrm{~A}-11 \mathrm{H} 11 \mathrm{H} 32 \mathrm{ABC}$ & 01-01-1958 & 5,980 & 700 & 5,280 & \\
\hline 145 & A-12-07 32B UNSURV & 07-01-1975 & 3,585 & 92 & 3,493 & \\
\hline 146 & A-12-08 20DAD & 05-05-1987 & 5,880 & 168.8 & 5,711 & \\
\hline 147 & A-12-08 21CCA2 & 05-04-1987 & 5,839 & 98 & 5,741 & \\
\hline 148 & A-12-08 21CCC1 & $11-07-1974$ & 5,770 & 69 & 5,701 & 1 \\
\hline 149 & A-12-08 21CDC2 & 11-19-1993 & 5,790 & 68.8 & 5,721 & \\
\hline 151 & A-12-08 22CAC & 11-08-1974 & 5,920 & 258 & 5,662 & \\
\hline 152 & A-12-08 22CCC1 & 02-13-1998 & 5,840 & 126.1 & 5,714 & \\
\hline 153 & A-12-08 22CDA & 11-08-1974 & 5,900 & 79 & 5,821 & \\
\hline 154 & A-12-08 22DCB & 05-06-1987 & 5,880 & 89.2 & 5,791 & \\
\hline 155 & A-12-08 24DAD & 05-05-1987 & 5,760 & 218.9 & 5,541 & \\
\hline 156 & A-12-08 25AAC & 11-19-1993 & 5,562 & 164.8 & 5,397 & \\
\hline 157 & A-12-08 25ABB & 05-05-1987 & 5,820 & 274.1 & 5,546 & \\
\hline 158 & A-12-08 25ACC & 05-05-1987 & 5,590 & 151.27 & 5,439 & \\
\hline 159 & A-12-08 25ADC & 10-17-1974 & 5,523 & 72.5 & 5,451 & 1 \\
\hline 160 & A-12-08 25CCA & $10-17-1974$ & 5,517 & 87 & 5,430 & \\
\hline
\end{tabular}




\section{Hydrology of the Mogollon Highlands, Central Arizona}

Table 6. Selected wells for which water level data are available, Mogollon Highlands, central Arizona—Continued

\begin{tabular}{|c|c|c|c|c|c|c|}
\hline $\begin{array}{c}\text { Map code } \\
\text { (see fig. 19) }\end{array}$ & Station name & $\begin{array}{l}\text { Date of most } \\
\text { recent water-level } \\
\text { measurement }\end{array}$ & $\begin{array}{l}\text { Land surface } \\
\text { altitude } \\
\text { (feet) }\end{array}$ & $\begin{array}{l}\text { Water depth } \\
\text { below land surface } \\
\text { (feet) }\end{array}$ & $\begin{array}{c}\text { Water-table } \\
\text { altitude } \\
\text { (feet) }\end{array}$ & Notes \\
\hline 162 & A-12-08 25DCB & 05-05-1987 & 5,470 & 188.1 & 5,282 & \\
\hline 163 & A-12-08 26DAB & 02-13-1998 & 5,645 & 100.1 & 5,545 & \\
\hline 166 & A-12-08 29AAA2 & 09-09-2001 & 5,755 & $1,377.5$ & 4,378 & 2 \\
\hline 167 & A-12-08 29AAB & 11-07-1974 & 5,740 & 100.5 & 5,640 & \\
\hline 168 & A-12-08 29BAB & 05-04-1987 & 5,705 & 88.9 & 5,616 & \\
\hline 172 & A-12-08 36CBB & $11-07-1974$ & 5,435 & 336 & 5,099 & \\
\hline 173 & A-12-09 19BAC & 05-05-1987 & 5,715 & 114.1 & 5,601 & \\
\hline 174 & A-12-09 19CCC1 & $10-17-1974$ & 5,620 & 79 & 5,541 & 1 \\
\hline 175 & A-12-09 30BBA1 & $11-28-1968$ & 5,545 & 28.5 & 5,517 & 1 \\
\hline 176 & A-12-09 30BBA5 & 05-05-1987 & 5,556 & 23.76 & 5,532 & \\
\hline 178 & A-12-09 31BAC2 & 05-06-1987 & 5,580 & 229.8 & 5,350 & \\
\hline 179 & A-12-09 36CBB & 01-01-1971 & 5,450 & 680 & 4,770 & \\
\hline 186 & A-12-17 32CAD & 10-02-1969 & 6,637 & 543.5 & 6,094 & \\
\hline 188 & A-13-05 05BDC & 10-14-1997 & 3,110 & 57.1 & 3,053 & \\
\hline 189 & A-13-05 05DAB2 & $12-01-1976$ & 3,095 & 45.6 & 3,049 & \\
\hline 190 & A-13-05 06DCB3 & 03-23-1982 & 3,062 & 18.27 & 3,044 & \\
\hline 191 & A-13-05 08AAB2 & 03-26-1981 & 3,074 & 25.71 & 3,048 & \\
\hline 192 & A-13-05 09DBA1 & 04-09-1981 & 3,190 & 137.48 & 3,053 & \\
\hline 193 & A-13-05 09DCC & 03-23-1982 & 3,078 & 47.54 & 3,030 & \\
\hline 194 & A-13-05 11DAB & 01-25-1982 & 3,210 & 94.07 & 3,116 & \\
\hline 195 & A-13-05 13BAC1 & $12-08-1976$ & 3,195 & 93.3 & 3,102 & \\
\hline 196 & A-13-05 13BDA & 03-31-1977 & 3,190 & 12.5 & 3,178 & \\
\hline 197 & A-13-05 15AAA & 03-28-1983 & 3,129 & 40.99 & 3,088 & \\
\hline 198 & A-13-05 15BAC & $12-02-1976$ & 3,105 & 35 & 3,070 & \\
\hline 199 & A-13-05 16ACB2 & 08-26-1981 & 3,048 & 15.98 & 3,032 & \\
\hline
\end{tabular}


Table 6. Selected wells for which water level data are available, Mogollon Highlands, central Arizona—Continued

\begin{tabular}{|c|c|c|c|c|c|c|}
\hline $\begin{array}{l}\text { Map code } \\
\text { (see fig. 19) }\end{array}$ & Station name & $\begin{array}{l}\text { Date of most } \\
\text { recent water-level } \\
\text { measurement }\end{array}$ & $\begin{array}{l}\text { Land surface } \\
\text { altitude } \\
\text { (feet) }\end{array}$ & $\begin{array}{l}\text { Water depth } \\
\text { below land surface } \\
\text { (feet) }\end{array}$ & $\begin{array}{l}\text { Water-table } \\
\text { altitude } \\
\text { (feet) }\end{array}$ & Notes \\
\hline 200 & A-13-05 21ABD2 & $01-28-1982$ & 3,015 & 11.54 & 3,003 & \\
\hline 201 & A-13-05 21BAB & 08-26-1981 & 3,021 & 12.85 & 3,008 & \\
\hline 202 & A-13-05 26ADA & 02-02-1977 & 3,390 & 389.72 & 3,000 & \\
\hline 203 & A-13-05 27CAD & $01-28-1982$ & 3,010 & 72.45 & 2,938 & \\
\hline 204 & A-13-05 27DCB2 & 11-09-1981 & 2,995 & 28.3 & 2,967 & \\
\hline 205 & A-13-06 11BAB & 03-10-1978 & 3,670 & 35.1 & 3,635 & \\
\hline 206 & A-13-06 13BCD & 02-15-1978 & 4,500 & 233 & 4,267 & \\
\hline 207 & A-13-06 23BBC & 09-22-1966 & 4,420 & 347 & 4,073 & \\
\hline 208 & A-13-07 14BAB & 10-13-1997 & 5,955 & 729.9 & 5,225 & \\
\hline 209 & A-13-10 06ADA & $02-10-1972$ & 6,865 & 472 & 6,393 & \\
\hline 210 & A-13-10 24DCC & $10-08-1963$ & 7,276 & 447 & 6,829 & \\
\hline 211 & A-13-10 25CAA & 06-10-1964 & 7,334 & 427 & 6,907 & \\
\hline 212 & A-13-15 14DCA & 10-01-1971 & 6,830 & 910 & 5,920 & \\
\hline 213 & A-14-04 13BDA & 10-31-1979 & 3,120 & 30 & 3,090 & \\
\hline 214 & A-14-05 26DAB & 05-27-1981 & 3,665 & 550.8 & 3,114 & \\
\hline 215 & A-14-06 26BDC & 05-26-1981 & 4,400 & 240 & 4,160 & \\
\hline 216 & A-14-10 02ACB & 07-11-1978 & 6,697 & 295 & 6,402 & 1 \\
\hline 217 & A-14-10 07CDB & 04-16-1985 & 6,850 & 517.5 & 6,333 & \\
\hline 218 & A-14-10 30ACA & 07-13-1966 & 6,900 & 867 & 6,033 & \\
\hline 219 & A-14-10 32DBD & 10-13-1997 & 6,855 & 332.1 & 6,523 & \\
\hline 220 & A-14-11 09ADC & 10-17-1997 & 6,905 & 507.5 & 6,398 & \\
\hline 221 & A-14-11 09DCA & 07-20-1966 & 6,885 & 471.5 & 6,414 & \\
\hline 222 & A-14-11 12BCD & 07-21-1966 & 6,730 & 358.4 & 6,372 & \\
\hline 224 & A-14-22 13CBC & 09-06-1972 & 5,697 & 394.3 & 5,303 & \\
\hline 225 & A-15-11 05BDC & 06-22-1966 & 6,710 & 640.3 & 6,070 & \\
\hline 226 & A-15-11 33DCD & 09-18-1972 & 6,760 & 385 & 6,375 & \\
\hline 227 & A-15-11 34DCD & 09-20-1966 & 6,810 & 461.32 & 6,349 & \\
\hline 228 & A-15-12 15DDC & 10-17-1997 & 6,503 & 669.3 & 5,834 & \\
\hline 230 & A-15-13 30A & 06-30-1967 & 5,993 & 99.6 & 5,893 & \\
\hline 231 & A-16-09 10CCC1 & $12-10-1976$ & 7,845 & 30 & 7,815 & \\
\hline
\end{tabular}




\section{Hydrology of the Mogollon Highlands, Central Arizona}

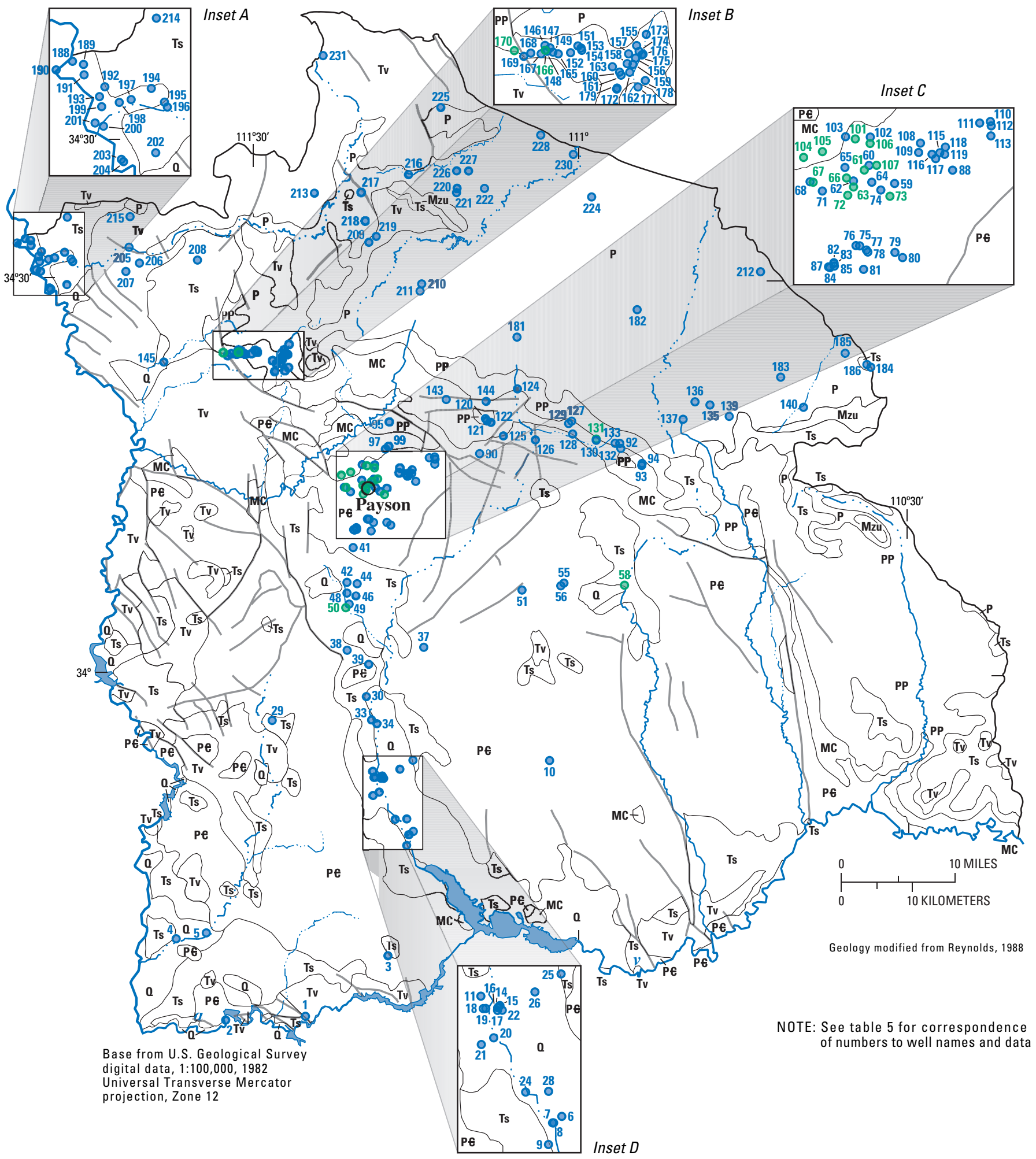

Figure 18. Selected wells for which water-level data are available, Mogollon Highlands, central Arizona. 


\section{EXPLANATION}

\begin{tabular}{|c|c|}
\hline $\mathbf{0}$ & SURFICIAL DEPOSITS, MOSTLY ALLUVIUM-Holocene to Middle Pleistocene \\
\hline Ts & SEDIMENTARY ROCKS—Pliocene to Middle Miocene \\
\hline Tv & VOLCANIC ROCKS_Pliocene to Middle Miocene \\
\hline Mzu & SEDIMENTARY ROCKS, UNDIFFERENTIATED—Cretaceous \\
\hline $\mathbf{P}$ & SEDIMENTARY ROCKS—Permian (Kaibab Formation and Coconino Sandstone) \\
\hline PP & $\begin{array}{l}\text { SEDIMENTARY ROCKS_Permian and Pennsylvanian (Schnebly Hill Formation, } \\
\text { Supai Formation, and Naco Formation) }\end{array}$ \\
\hline MC & $\begin{array}{l}\text { SEDIMENTARY ROCKS—Mississippian to Cambrian (Redwall Limestone, Martin Formation, } \\
\text { and Tapeats Sandstone) }\end{array}$ \\
\hline PE & PROTEROZOIC ROCKS \\
\hline & FAULT \\
\hline 2130 & WELL AND WELL IDENTIFIER \\
\hline $\begin{array}{c}104 \\
0\end{array}$ & ARIZONA DEPARTMENT OF WATER RESOURCES INDEX WELL AND WELL IDENTIFIER \\
\hline
\end{tabular}

Figure 18. Continued.

The shallowest water levels tend to be in the wells of lower Tonto Creek Basin where median depth to water in 109 wells is $20 \mathrm{ft}$, and the maximum recorded depth to water is $123 \mathrm{ft}$. In the Payson area, 125 wells have a median depth to water of $55 \mathrm{ft}$ and a maximum depth to water of $342 \mathrm{ft} ; 82$ wells in the Pine-Strawberry area have a median depth to water of $100 \mathrm{ft}$ and a maximum depth to water of $1,379 \mathrm{ft}$; and on the Colorado Plateau, 49 wells show a median depth to water of $438 \mathrm{ft}$ and a maximum depth to water of $910 \mathrm{ft}$. Finally, wells in the tablelands from the East Verde River eastward have a median depth to water of $47.5 \mathrm{ft}$ and a maximum depth to water of $700 \mathrm{ft}$ (table 6 and fig. 18).

Although water levels have been repeatedly measured in some wells, gaps of 5 to 10 years are common for wells in and around Payson and in the PineStrawberry area (fig. 19 and table 6). On the basis of data from the few wells which have been measured repeatedly since the 1970s or 1980s, water levels at depths below $300 \mathrm{ft}$ generally were stable into the late $1980 \mathrm{~s}$, fluctuated after the 1980s, and showed a general but not universal declining trend since the mid-1990s (fig. 19). Wells deeper than $300 \mathrm{ft}$ for which repeat measurements are available show little water-level fluctuation (fig. 19).

Pumping discharge values are recorded for 131 wells in the USGS database, and there are no repeated measurements available. About 70 percent of wells for which there is a record show discharges of less than $50 \mathrm{gal} / \mathrm{min}$. The highest density of recorded welldischarge values is near Payson, Pine-Strawberry, and near the mouth of West Clear Creek. The mean discharge of 19 wells in the Payson area is $35 \mathrm{gal} / \mathrm{min}$, but only
4 wells have discharges above the mean. Pine-Strawberry wells also yield about $35 \mathrm{gal} / \mathrm{min}$. Almost all wells having discharges of $50 \mathrm{gal} / \mathrm{min}$ or more are on the Colorado Plateau where they are drilled mainly into the Coconino Sandstone. The few discharge values that are available for wells on the tablelands east of the East Verde River ranged from 13 to $50 \mathrm{gal} / \mathrm{min}$.

\section{Hydrogeology}

Almost all the rock units within the study area contain some water-bearing zones, although the hydrogeology of some units have been studied little or not at all. Working in the Flagstaff area, Bills and others (2000) characterize the hydrologic properties of the Paleozoic sedimentary rocks and regard all of the units from the Kaibab Formation to the Middle Supai Formation as part of the regional $\mathrm{C}$ aquifer; they describe the Lower Supai Formation as a confining unit and regard the Redwall Limestone and Martin Formation as a limestone aquifer. The characterization appears appropriate for the Mogollon Highlands as well. In addition, the Naco Formation, which does not occur in the Flagstaff area, has many of the properties of underlying carbonate units, including dissolution features that are conducive to flow, and it is considered here to be a component of the limestone aquifer. In some parts of the study area, rocks that are water bearing elsewhere in Arizona have been uplifted along high-angle faults and drained. 
Colorado Plateau wells
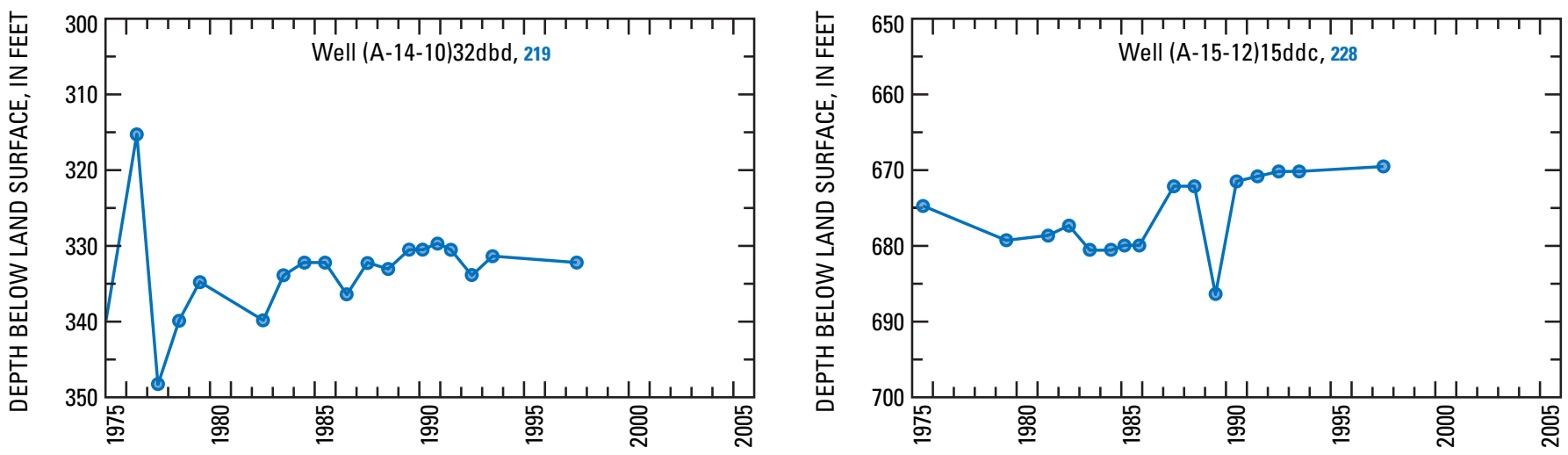

Lower Tonto Basin wells
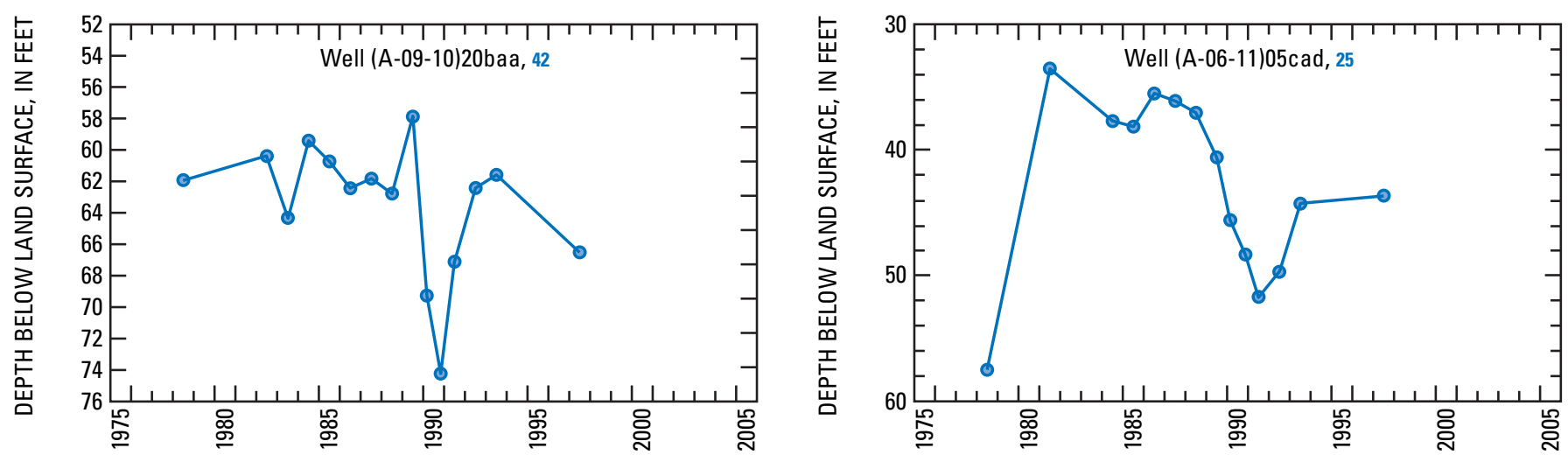

Pine well
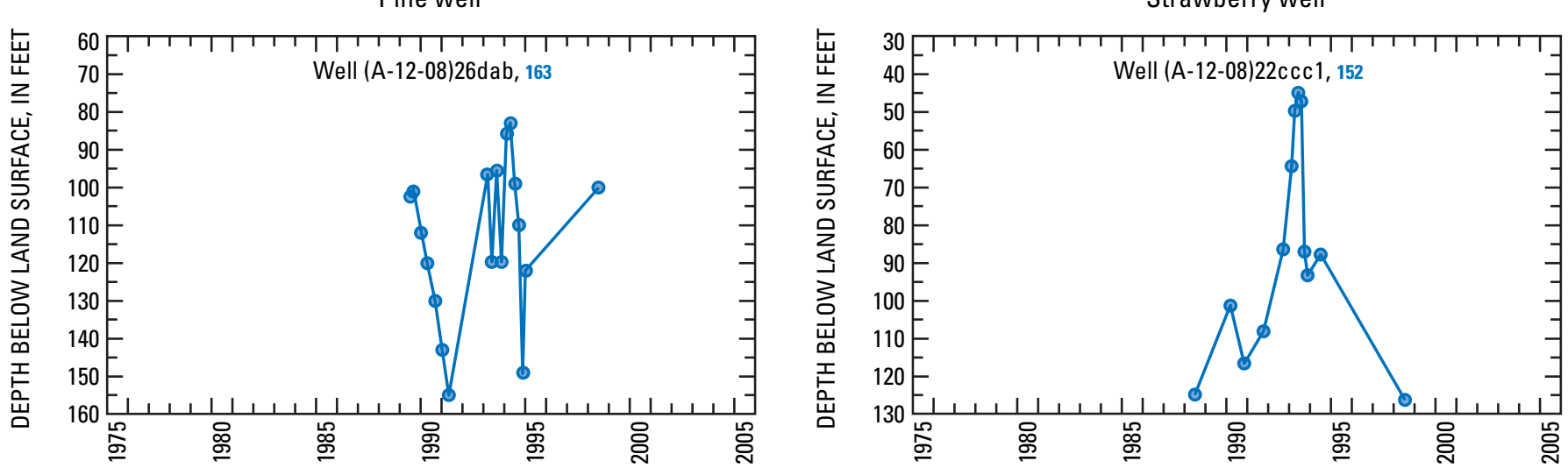

Figure 19. Time series of water depths in selected wells, Mogollon Highlands, Arizona. 
Payson wells
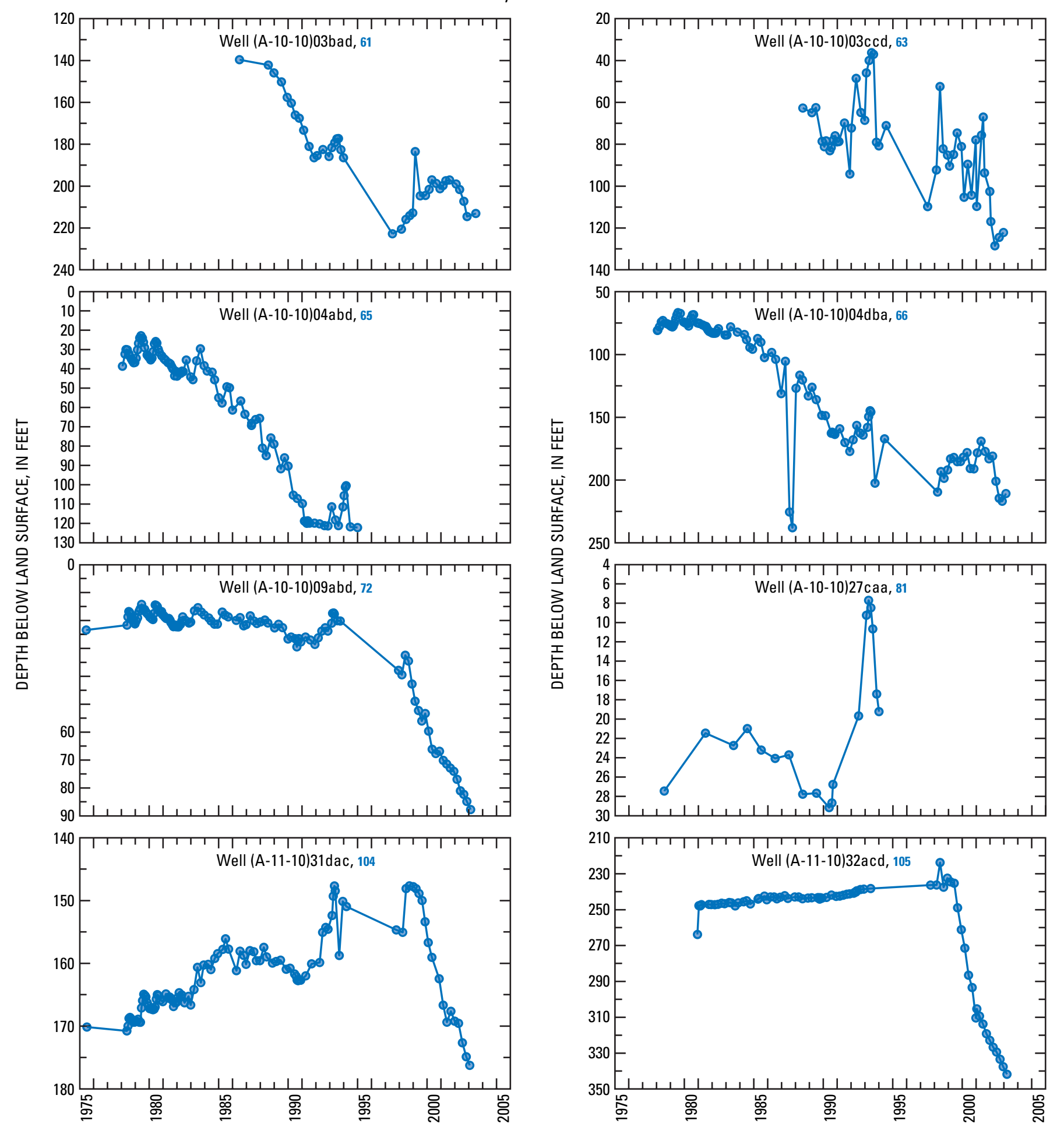

NOTE: See fig. 18 for well location

Figure 19. Continued. 


\section{Hydrogeologic Units}

\section{Tertiary-Quaternary Alluvium and Basin Fill}

The basin fill of the Tonto Creek Basin generally is of low permeability, and well productivity is low (Denis, 1981). Water resources in the basin are lightly developed and the alluvial aquifer has not been well studied. Wells in the alluvium of the lower Tonto Creek Basin typically are shallow and of low productivity.

\section{Tertiary Volcanic Rocks}

The mainly basaltic Tertiary volcanic rocks in the northwestern part of the study area are the only such rocks in the study area known to be of any hydrogeologic significance. Two low-discharge springs in Fossil Creek Canyon, (A-12-07)22C (table 4 and fig. 15, no. 12) and (A-12-07)21D (not shown), most likely flow from a locally recharged aquifer. Few wells are completed in volcanic rocks, and those for which production information is available show discharges generally below $20 \mathrm{gal} / \mathrm{min}$.

\section{Upper Paleozoic Rocks}

The Coconino Sandstone is the primary waterbearing unit of the $\mathrm{C}$ aquifer elsewhere in Arizona, particularly in the Little Colorado River Basin to the north of the study area (Hart and others, 2002). Within the study area, the Coconino Sandstone is the most important aquifer for well production on the Colorado Plateau. The Coconino Sandstone and the Kaibab Formation, where it exists, are also the transport zones for recharge of underlying aquifers. Although a mound of ground water, centered north of the Tonto Creek drainage basin, is believed to exist along the edge of the Mogollon Rim (Hart and others, 2002), no significant springs issue from cliffs formed by the Coconino Sandstone within the study area except for Buckhorn Spring, which discharges from the unit into West Clear Creek. Both the Kaibab Formation and the Coconino Sandstone show extensive secondary permeability in the form of solution features in limestone and pervasive fracturing that contribute to rapid vertical flow.

\section{Middle Paleozoic Rocks}

The base of the $\mathrm{C}$ aquifer is in the middle Paleozoic rocks of either the Schnebly Hill Formation or the Supai Formation in the eastern part of the study area (Hart and others, 2002). The $\mathrm{C}$ aquifer does not seem to discharge from the face of the Mogollon Rim in the western part of the study area. The stratigraphically highest discharge of any significance comes from the perennial springs of the upper East Verde River, Tonto Creek, Christopher Creek, and Canyon Creek that issue from the Fort Apache Member of the Schnebly Hill Formation (fig. 15). These springs are found within prominent recesses in the wall of the Mogollon Rim that are probably formed from sapping erosion related to the spring position (Higgins, 1990). The consistent north to northeast trend of the recesses suggests that spring location is related to large-scale structural features. The existence of such features seems to be consistent with the occurrence of springs at the convergence of lineations deduced by Gettings and Bultman (geologists, U.S. Geological Survey, written commun., 2003). East of Pieper Hatchery Spring, springs along the upper face of the Mogollon Rim have low discharges and issue mainly from the clastic sedimentary rocks of the Schnebly Hill Formation or from the underlying Supai Formation (fig. 15).

The only wells below the crest of the Mogollon Rim that produce water from the Schnebly Hill Formation are in the Strawberry area. In neighboring Pine, most wells are completed in the Supai Formation, and the few well-discharge data available show yields of about $10-30 \mathrm{gal} / \mathrm{min}$ in the Pine area and $20-80 \mathrm{gal} / \mathrm{min}$ in Strawberry. Kaczmarek (2003) suggests that this is because well production in both areas is dependent on the proximity of fractures within the host rocks, but the somewhat greater primary porosity of the Schnebly Hill Formation allows for some ground-water storage that permits more rapid and dependable flow into fractured areas as water is pumped from them. The importance of fractures and other secondary permeability features in conductance of ground-water flow is illustrated by the ranges of transmissivity and hydraulic conductivity values, more than three to four orders of magnitude, that have been published for wells completed in the $\mathrm{C}$ aquifer (Mann and Nemecek, 1983; Bills and others, 2000; Hart and others, 2002). The absence of spring discharge from the Fort Apache Member of the Schnebly Hill Formation above Pine and Strawberry, the low discharge from springs in the clastic rocks, and the generally poor production of wells in the Pine-Strawberry area suggest that the regional $\mathrm{C}$ aquifer does not intersect the face of the Mogollon Rim in this area; rather, the ground-water system within the upper Paleozoic rocks of this area appears to be a local aquifer. 
The Naco Formation has several characteristics, including fractures, open bedding planes, and solution features that would favor rapid transmission of a large volume of ground water, but the unit generally stands above the saturated zone in the study area. Wells penetrating the Naco Formation in the Pine area commonly intersect voids, and there is little production from the unit (Kaczmarek, 2003). During drilling of the Strawberry exploratory well, (A-12-08)29AAA2 (table 6 and fig. 18, insert B; no. 166), no cuttings were obtained below a depth of $970 \mathrm{ft}$ because of loss of fluid circulation associated with large voids or fractures at that level. Voids were repeatedly encountered and drilling was finally suspended at a depth of $1,460 \mathrm{ft}$ because of unacceptable fluid losses. On the basis of well logs, geophysical data, and regional stratigraphy, Corkhill (2000) placed the Naco Formation between 1,040 and 1,295 feet deep in this area, about $85 \mathrm{ft}$ above the saturated zone. At Fossil Creek, springs discharge from rocks at the base of the Naco Formation or the top of the Redwall Limestone- the only location where saturation of the Naco is evident. Because of its physical characteristics, however, the Naco Formation may be considered to be part of the limestone aquifer that generally is associated with the lower Paleozoic rocks of the Redwall Limestone and Martin Formation. The limestone aquifer must be supplied at least in part from the leakage through the overlying PermianPennsylvanian rocks from the $\mathrm{C}$ aquifer and thus ground water must travel through the Naco Formation at some locations beneath the Plateau.

\section{Lower Paleozoic Rocks}

The limestone aquifer is composed mainly of rocks of the Redwall Limestone and Martin Formation. Within the study area, the main discharge points from the limestone aquifer are the large-volume springs in the middle reaches of the East Verde River and its tributaries and in Fossil Creek. Discharge from the limestone aquifer also is likely into all the major streams draining the study area, except perhaps West Clear Creek. Wells drilled into the limestone aquifer are few, are mainly concentrated in the Tonto Village-Kohls Ranch area (fig. 1), and are not highly productive. The limestone aquifer has not been extensively studied. Farrar (1980) investigated the hydrological properties of the Redwall Limestone and the Jerome Member of the Martin Formation and found that primary porosity was of little importance in both formations. In the Mooney Falls Member of the Redwall Limestone, the only member of the formation that is present in the study area, Farrar found that virtually all secondary porosity was the result of karst formation that resulted in a highly variable distribution of solution conduits. Fractures and solute-widened bedding planes in the upper Jerome Member of the Martin Formation provide the secondary porosity of that unit. Caverns in the Martin Formation were most likely to occur at the intersection of large joints or faults. From eight wells in the Flagstaff area, Farrar (1980) reported specific capacity values ranging from $0.9 \mathrm{gal} / \mathrm{min} / \mathrm{ft}$ at the Supai-Redwall contact to $100 \mathrm{gal} / \mathrm{min} / \mathrm{ft}$ at the Redwall-Martin contact.

Two high-discharge springs flow from below the Paleozoic section in the study area. Tonto Natural Bridge Spring discharges from the Tapeats Sandstone (Feth and Hem, 1963), and R-C Spring east of Tonto Creek discharges from the Mazatzal Group quartzite (fig. 15 and table 3); however, both the volume of spring discharge and the nature of the rocks from which the springs discharge suggest that the main flow paths are through the limestone aquifer.

\section{Proterozoic Igneous and Metamorphic Rocks}

The hydrogeological characteristics of the Payson granite and related intrusive rocks have been studied more extensively than any other units in the Mogollon Highlands because of Payson's reliance on the fracturedrock aquifer for its water supply (Southwest Groundwater Consultants, Inc., 1998; AGRA Earth and Environmental, Inc., 1999; Ploughe, 2000, 2001; Gæorama, Inc., 2001, 2003). The Payson granite is extensively fractured and faulted. Proterozoic faults typically are mineralized and of little hydrologic importance, but Tertiary faulting has created significant secondary permeability. Although most wells are shallow, the town of Payson began an exploratory welldrilling program north of the town in 1999 in which water-bearing zones as deep as $750 \mathrm{ft}$ were located (Ploughe, 2000). On the basis of numerous aquifer tests throughout the area, transmissivity ranges from 40 to $2,270 \mathrm{ft}^{2} / \mathrm{d}$ and is greatest where wells are associated with major fracture systems (Southwest Ground-water Consultants, Inc., 1998). In general, shallow waterbearing zones are dependent on winter recharge and thus are highly susceptible to drought (Ploughe, 2001); however, water in deeper fracture systems might be fed by sources flowing into the system from the Mogollon Rim (Gæorama, Inc., 2003). The lowest productive level of the Payson granite might be as deep as $1,000 \mathrm{ft}$ (Gæorama, Inc., 2003). The Payson granite aquifer is characterized by numerous local ground-water divides so that the effects of drawdown in one well or well field may be restricted to a localized area (AGRA Earth and Environmental, Inc., 1999). The few springs that discharge from Proterozoic igneous rocks show low discharges (table 4 and fig. 15, nos. 40 and 41). 
Other Proterozoic rocks in the area are little studied. A handful of wells are completed in the Proterozoic rocks of the Mazatzal Mountains and the Sierra Ancha; a few springs emit discharges of less than $10 \mathrm{gal} / \mathrm{min}$ (table 4 and fig. 15, nos. 16 and 21). In general, such rocks probably are barriers to ground-water flow where they are in contact with water-bearing rocks.

\section{Water Chemistry}

Chemical data are available for 23 springs (table 7 and figs. 20-23), 81 wells (table 8 and figs. 24 and 25), and 4 streams (table 9). Surface and ground waters in the study area are largely dilute waters that have specific conductance values below $1,000 \mu \mathrm{S} / \mathrm{cm}$. A specific conductance value typically reflects the amount of material dissolved in water and enables an estimate of the total solute concentration. The total solute concentration, in $\mathrm{mg} / \mathrm{L}$, typically is on the order of two-thirds of the specific conductance value. Stream and spring temperatures can vary greatly as a function of season, time of collection, discharge rate, and physical setting. Stream chemistry reflects that of the ground water that supports the base flow of the stream and the volume and composition of varying seasonal runoff. During the lowest flows in smaller streams, the total solute concentration can be significantly increased by evaporation.

Concentrations of sodium, chloride, and sulfate tend to be higher in ground waters that have longer residence times in their respective aquifers. Both major and minor dissolved constituents reflect the rocks through which the waters have flowed.

\section{Chemistry of Spring Waters}

Thirty-two analyses of varying completeness are available for the 23 springs for which data were identified or developed (table 7 and figs. 20-22). In addition to the these chemical analyses, 22 samples were collected from 19 springs for stable hydrogen- and oxygen-isotope data $\left(\delta^{2} \mathrm{H}\right.$ and $\left.\delta^{18} \mathrm{O}\right)$ in this study, and 10 samples of water and rock were taken for strontium isotope $\left({ }^{87} \mathrm{Sr} /{ }^{86} \mathrm{Sr}\right.$ ) analyses (tables 10 and 11 and figs. 20 and 23). Three of the hydrogen- and oxygenisotope samples were collected from separate outlets in Fossil Springs. The $\delta^{2} \mathrm{H}$ and $\delta^{18} \mathrm{O}$ data plot in a tight group slightly above and left of the meteoric water line (fig. 23), indicating that the recharge is dominated by precipitation that falls during the coldest part of the year (Craig, 1961). When compared to stable-isotope values for precipitation collected at Flagstaff from 1961 through 1971, values for the spring samples from this study fall within the range of values for cold-season precipitation samples, those having $\delta^{18} \mathrm{O}$ values smaller than -9 per mil (fig. 23). Data from one spring sample, Pig Spring in mafic granitic rocks south of Payson, were discarded because the $\delta^{18} \mathrm{O}$ value of about -2 per mil reflects a sample that underwent substantial evaporation prior to collection and is not representative of spring discharge at that site. The range of the spring isotopic data, although narrow relative to recent precipitation data, indicates that most of the springs discharging at or near the Mogollon Rim, particularly those having the highest discharge, isotopically resemble the discharge of Fossil Springs (table 10, no. 14 and fig. 23). In general, those springs having lower discharge and those farther from the Mogollon Rim reflect either a warm-season component or evaporative enrichment. Strontiumisotope data generally show a close relation between isotope composition of water and that of the host rocks from which the springs discharge (table 11).

The specific-conductance values for the 23 springs range from 25 to $753 \mu \mathrm{S} / \mathrm{cm}$. These are dilute, fresh waters. Three of the springs-(A-12-07)21D UNSURV (table 7, no. 11), (A-12-10)01BDA (table 7, no. 46 and figs. 20 and 21), and (A-12-13H)01BBD (table 7, no. 62 and figs. 20 and 21) — are calcium sodium bicarbonate types; the remainder are calcium magnesium bicarbonate types (fig. 21), following the hydrochemical facies scheme described by Back (1961). The springs discharging the most dilute waters (specific conductance $\leq 250 \mu \mathrm{S} / \mathrm{cm}$ ) are four of the seven on the Colorado Plateau-Pivot Rock, (A-12-10)01BDA, (A-12-12)11BAB, and (A-12-13H)01BBD (table 7, nos. 30, 46, 57, and 62 and figs. 20 and 22A) - three near the Mogollon Rim in the headwaters area of Tonto Creek-Horton, Tonto, and See Springs (table 7, nos. 56, 52, and 61 and figs. 20 and 22A) — and Bear Flat Spring, 5 to 6 mi downstream from the near-rim group (table 7, no. 54 and figs. 20 and 22A). The reported value for Dripping Springs of $74 \mu \mathrm{S} / \mathrm{cm}$ probably is in error as it does not agree with the analytical data (table 7, no. 25 and figs. 20 and 22A). Spring (A-12-10)01BDA (table 7, no. 46, figs 20 and $22 A$ ) is the most dilute and owes its composition to recharge into and flow through the Coconino Sandstone. The Coconino is a clean, indurated quartz (98 percent) sandstone, containing about 2 percent feldspar and chert, that is cemented by silica, calcite, and iron oxides. Feldspar grains in the Coconino are the primary source of solutes in waters derived from that formation. The reported calcium, magnesium, and sodium concentrations and low bicarbonate concentration rule out a limestone or calcite contribution, as does the low $\mathrm{pH}$, which also indicates relatively brief interaction with the feldspars. This spring is indicative of the starting chemistry of water discharged by most of the springs in the study area. Departures from this model are the result of water-rock interactions along respective flow paths. 
Table 7. Physical and chemical properties and chemical composition of spring waters in the Mogollon Highlands, central Arizona $[\mu \mathrm{S} / \mathrm{cm}$, microsiemens per centimeter; mg/L; milligrams per liter; $\mu \mathrm{g} / \mathrm{L}$, micrograms per liter; FET, fixed end point titration; IT, incremental titration; ANC, acid neutralizing capacity; <, less than. Dashes indicate no data]

\begin{tabular}{|c|c|c|c|c|c|c|c|c|}
\hline $\begin{array}{c}\text { Map code } \\
\text { (see } \\
\text { fig. 20) }\end{array}$ & Station name & Spring name & Date & Time & $\begin{array}{c}\text { Specific } \\
\text { conductance } \\
(\mu S / \mathrm{cm})\end{array}$ & pH, field & $\begin{array}{c}\text { Water } \\
\text { temperature } \\
\text { (degrees } \\
\text { Celsius) }\end{array}$ & $\begin{array}{l}\text { Oxygen, } \\
\text { dissolved } \\
\text { (mg/L) }\end{array}$ \\
\hline 54 & A-10H12 24AAB & Bear Flat & 07-16-1975 & 1100 & 250 & 7.5 & --- & --- \\
\hline 54 & A-10H12 24AAB & Bear Flat & 10-20-1952 & --- & 348 & --- & 16.5 & --- \\
\hline 58 & A-11-12 26BDB & $\mathrm{R}-\mathrm{C}$ & 07-31-1997 & 1130 & 330 & 7.44 & 15.5 & 6.0 \\
\hline 58 & A-11-12 26BDB & $\mathrm{R}-\mathrm{C}$ & 05-14-1952 & --- & 275 & --- & 9 & --- \\
\hline 37 & A-11-10 08AAD & Big & 08-21-1997 & 900 & 480 & 7.3 & 16 & 47.8 \\
\hline 22 & A-11-09 05DCA & Tonto Natural Bridge & 08-19-1997 & 830 & 620 & 7.4 & 20 & 5.6 \\
\hline 50 & A-11-12 20DAB & Indian Gardens & 07-15-1975 & 1300 & 700 & 7.1 & --- & --- \\
\hline 50 & A-11-12 20DAB & Indian Gardens & 07-30-1997 & 1430 & 645 & 7.13 & 14.5 & 6.2 \\
\hline 50 & A-11-12 20DAB & Indian Gardens & 05-17-1952 & --- & 497 & --- & 14.5 & --- \\
\hline 42 & A-11H10 24BCA1 & & 08-04-1998 & 1400 & 290 & 7.3 & 11 & 5.5 \\
\hline 52 & A-12-12 33BAC & Tonto & 07-31-1997 & 900 & 145 & 7.09 & 9 & 11.5 \\
\hline 52 & A-12-12 33BAC & Tonto & 10-17-1952 & --- & 174 & --- & 9 & --- \\
\hline 10 & A-12-07 21DCD1 & & 05-24-1978 & 945 & 560 & 7.3 & 16 & --- \\
\hline 11 & A-12-07 21DCD2 & & 08-18-1997 & 1100 & 470 & 7.6 & 25 & 5.7 \\
\hline 35 & A-12-09 24CCC & Geronimo & 08-20-1997 & 900 & 530 & 7.4 & 14.5 & 43.6 \\
\hline 12 & A-12-07 22C UNSURV & & 05-24-1978 & 1530 & 510 & 8.2 & 19 & --- \\
\hline 14 & A-12-07 14D UNSURV & Fossil & 05-24-1978 & 1100 & 700 & 6.7 & 22 & --- \\
\hline 14 & A-12-07 14D UNSURV & Fossil & 08-07-1998 & 1030 & 720 & 7 & 21 & 5.1 \\
\hline 14 & A-12-07 14D UNSURV & Fossil & 07-15-1959 & --- & 745 & 7.3 & 21 & --- \\
\hline 14 & A-12-07 14D UNSURV & Fossil & 02-16-1952 & --- & 753 & --- & 21.5 & --- \\
\hline 48 & A-12-11 12AAC & & 08-22-1995 & 1430 & 305 & 7.38 & 13 & 7.0 \\
\hline 57 & A-12-12 11BAB & & 08-23-1995 & 1130 & 110 & 7.36 & 22 & 5.0 \\
\hline 46 & A-12-10 01BDA & & 08-22-1995 & 1200 & 25 & 6.34 & 16 & 3.5 \\
\hline 62 & A-12-13H01BBD & & 08-21-1995 & 1500 & 75 & 6.77 & 14 & 5.9 \\
\hline 30 & A-13-09 28ABB & Pivot Rock & 08-01-1994 & 1200 & 210 & 7.26 & 10 & 8.3 \\
\hline 27 & A-14-09 31DDC & Bear & 05-27-1959 & --- & 418 & 7.8 & 11 & --- \\
\hline 15 & A-14-08 32A UNSURV & Buckhorn & 05-28-1959 & --- & 401 & 8 & --- & --- \\
\hline 39 & A-11-10 04CAD & Webber & 10-22-2002 & 830 & 459 & 7.3 & 14.4 & 3.3 \\
\hline 61 & A-11-13 08CBB & See & $10-22-2002$ & 1500 & 250 & 7.7 & 9.5 & 8.2 \\
\hline 25 & A-12-09 30DDD2 & Dripping & 10-24-2002 & 1015 & 74 & 6.9 & 13.3 & 6.6 \\
\hline 56 & A-11-12 02BDB & Horton & 10-23-2002 & 1042 & 186 & 7.3 & 10.2 & 8.3 \\
\hline 43 & A-12-10 11CCD & Washington & 10-22-2002 & 1205 & 301 & 7.50 & 10.1 & 7.3 \\
\hline
\end{tabular}




\section{Hydrology of the Mogollon Highlands, Central Arizona}

Table 7. Physical and chemical properties and chemical composition of spring waters in the Mogollon Highlands, central Arizona-Continued

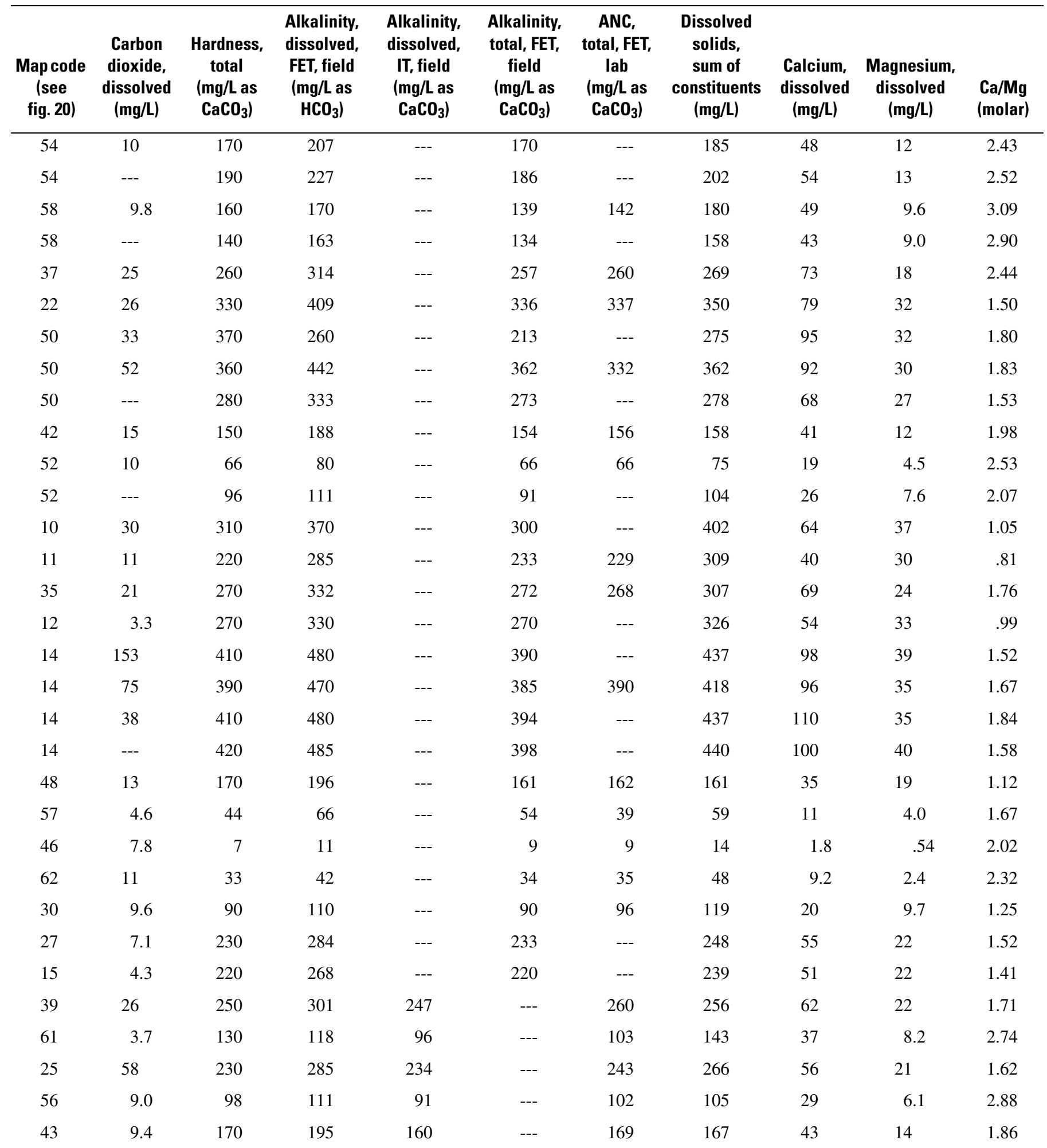


Table 7. Physical and chemical properties and chemical composition of spring waters in the Mogollon Highlands, central Arizona-Continued

\begin{tabular}{|c|c|c|c|c|c|c|c|c|c|c|}
\hline $\begin{array}{c}\text { Map } \\
\text { code (see } \\
\text { fig. 20) }\end{array}$ & $\begin{array}{l}\text { Sodium, } \\
\text { dissolved } \\
\text { (mg/L) }\end{array}$ & $\begin{array}{l}\mathrm{Ca} / \mathrm{Na} \\
\text { (molar) }\end{array}$ & $\begin{array}{l}\text { Potassium, } \\
\text { dissolved } \\
\text { (mg/L) }\end{array}$ & $\begin{array}{c}\mathrm{HCO}_{3} \\
\text { (molar) }\end{array}$ & $\begin{array}{l}\text { Sulfate, } \\
\text { dissolved } \\
\text { (mg/L) }\end{array}$ & $\begin{array}{l}\text { Chloride, } \\
\text { dissolved } \\
\text { (mg/L) }\end{array}$ & $\begin{array}{c}\text { Fluoride, } \\
\text { dissolved } \\
\text { (mg/L) }\end{array}$ & $\begin{array}{c}\text { Silica, } \\
\text { dissolved } \\
\text { (mg/L) }\end{array}$ & $\begin{array}{c}\text { Arsenic, } \\
\text { dissolved } \\
(\mu \mathrm{g} / \mathrm{L})\end{array}$ & $\begin{array}{c}\text { Boron, } \\
\text { dissolved } \\
(\mu \mathrm{g} / \mathrm{L})\end{array}$ \\
\hline 54 & 3.4 & 8.1 & 0.70 & 3.39 & 1.7 & 4.2 & 0.1 & 13 & --- & $<20$ \\
\hline 54 & --- & --- & --- & 3.72 & 2.3 & 3.0 & .2 & 15 & --- & --- \\
\hline 58 & 3.1 & 9.07 & .71 & 2.79 & 23 & 2.0 & $<.1$ & 7.7 & --- & 12 \\
\hline 58 & --- & --- & --- & 2.67 & 13 & 1.0 & .1 & 8.9 & --- & --- \\
\hline 37 & 3.3 & 12.63 & .54 & 5.14 & 4.6 & 2.2 & $<.1$ & 13 & $<1$ & 19 \\
\hline 22 & 6.4 & 7.09 & .94 & 6.71 & 3.2 & 6.1 & .16 & 19 & --- & 20 \\
\hline 50 & 3.8 & 14.34 & .80 & 4.26 & 1.1 & 3.4 & .1 & 10 & --- & $<20$ \\
\hline 50 & 3.2 & 16.4 & .72 & 7.24 & 2.7 & 3.5 & .11 & 10 & --- & 15 \\
\hline 50 & --- & --- & --- & 5.46 & 4.1 & 2.0 & .2 & 8.9 & --- & --- \\
\hline 42 & 1.4 & 16.93 & .63 & 3.08 & 3.0 & 1.1 & $<.1$ & 5.8 & $<1$ & $<16$ \\
\hline 52 & 1.3 & 8.17 & .83 & 1.31 & 1.7 & 1.0 & $<.1$ & 7.1 & --- & 6.8 \\
\hline 52 & --- & --- & --- & 1.82 & 3.1 & 2.0 & .2 & 8.7 & --- & --- \\
\hline 10 & 18 & 2.04 & 1.8 & 6.06 & 8.5 & 13 & .2 & 75 & --- & $<20$ \\
\hline 11 & 11 & 2.10 & 2.1 & 4.67 & 5.1 & 8.4 & .15 & 68 & --- & 31 \\
\hline 35 & 9.2 & 4.26 & .63 & 5.45 & 20 & 2.8 & .12 & 18 & --- & 17 \\
\hline 12 & 11 & 2.82 & 3.2 & 5.41 & 4.8 & 7.1 & .1 & 50 & --- & $<20$ \\
\hline 14 & 12 & 4.68 & 1.8 & 7.87 & 27 & 8.3 & .1 & 13 & --- & 60 \\
\hline 14 & 11 & 5.20 & 1.8 & 7.7 & 23 & 7.1 & .19 & 12 & $<1$ & 69 \\
\hline 14 & --- & --- & --- & 7.87 & 23 & 9.0 & .3 & 17 & --- & --- \\
\hline 14 & --- & --- & --- & 7.95 & 27 & 9.0 & .1 & 14 & --- & \\
\hline 48 & 1 & 20.08 & .50 & 3.22 & 2.4 & 1.1 & $<.1$ & 4.7 & --- & $<10$ \\
\hline 57 & 1.3 & 4.85 & .50 & 1.08 & 1 & 3.5 & $<.1$ & 5 & --- & 10 \\
\hline 46 & .70 & 1.47 & .80 & .18 & 1.2 & 1.6 & $<.1$ & 1.9 & --- & $<10$ \\
\hline 62 & 1.9 & 2.78 & .60 & .69 & 1.4 & .90 & .2 & 9.4 & --- & $<10$ \\
\hline 30 & 3.1 & 3.70 & .50 & 1.81 & 2.1 & 2.0 & $<.1$ & 27 & $<1$ & 10 \\
\hline 27 & --- & --- & --- & 4.65 & .60 & 4.0 & .1 & 21 & --- & --- \\
\hline 15 & --- & --- & --- & 4.39 & 1.6 & 6 & $<.1$ & 20 & --- & --- \\
\hline 39 & 4.2 & 8.47 & .70 & 4.93 & 5.2 & 3.6 & .2 & 10 & --- & --- \\
\hline 61 & 2.2 & 9.65 & .60 & 1.93 & 27 & 1.4 & .1 & 8.3 & --- & --- \\
\hline 25 & 8.2 & 3.92 & .70 & 4.67 & 2.2 & 6.3 & .1 & 31 & --- & --- \\
\hline 56 & 1.4 & 11.88 & .90 & 1.82 & 2.8 & 1.7 & $<.1$ & 8.2 & --- & --- \\
\hline 43 & 1.9 & 12.98 & .50 & 3.20 & 1.3 & 2.3 & $<.1$ & 7.7 & --- & --- \\
\hline
\end{tabular}




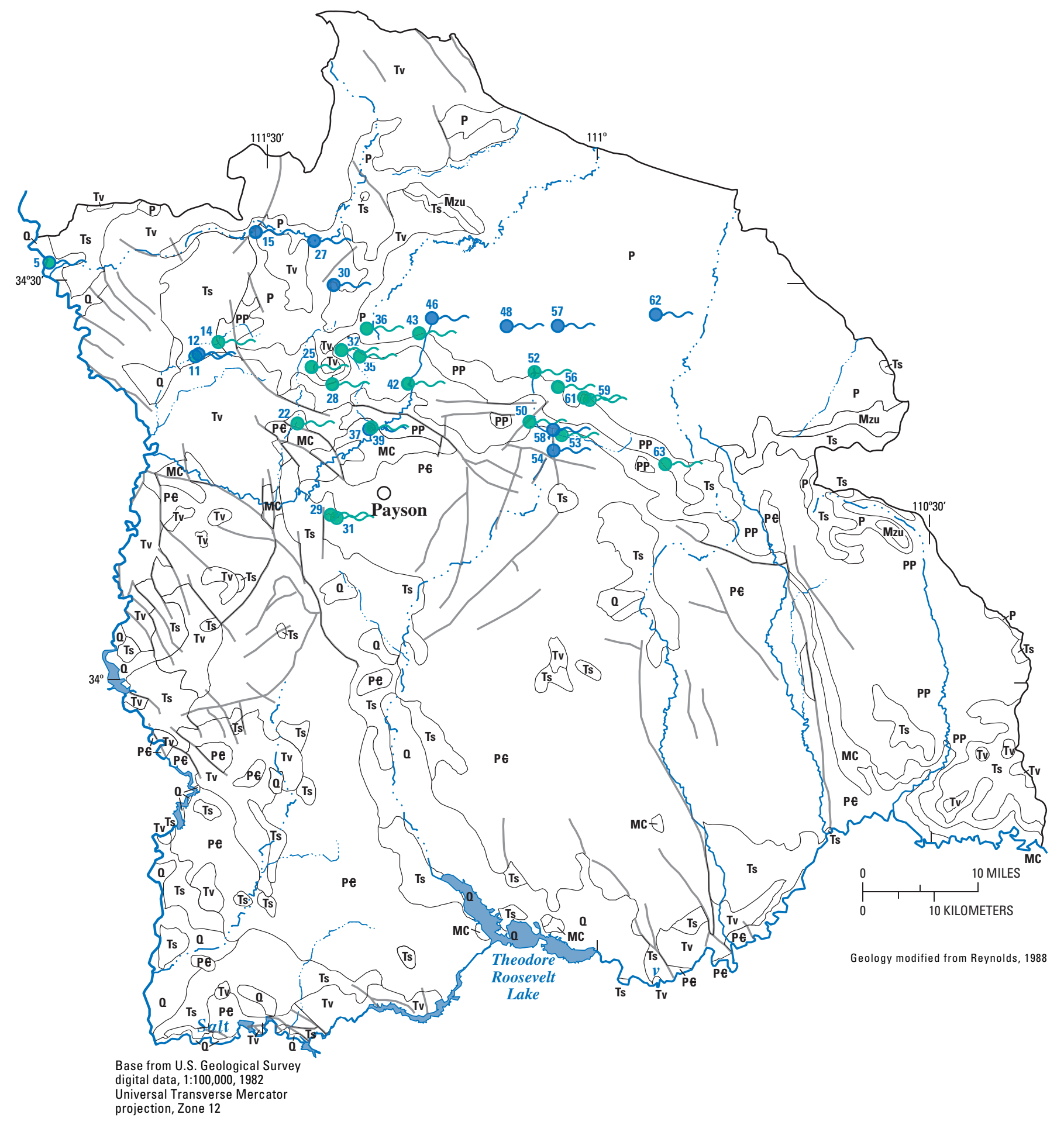

Figure 20. Springs for which chemical data are available and sampling sites for isotope analysis of spring water, Mogollon Highlands, central Arizona. 


\section{EXPLANATION}

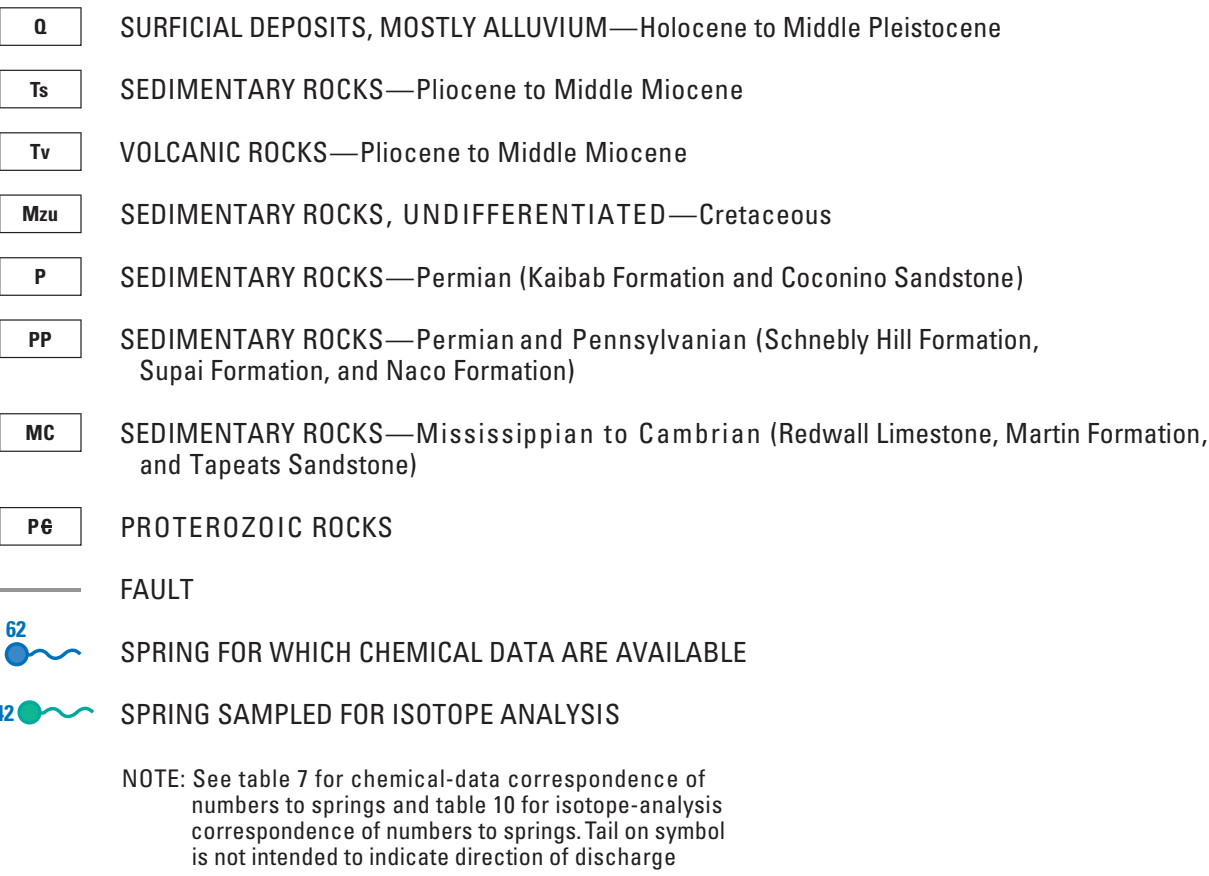

Figure 20. Continued. 


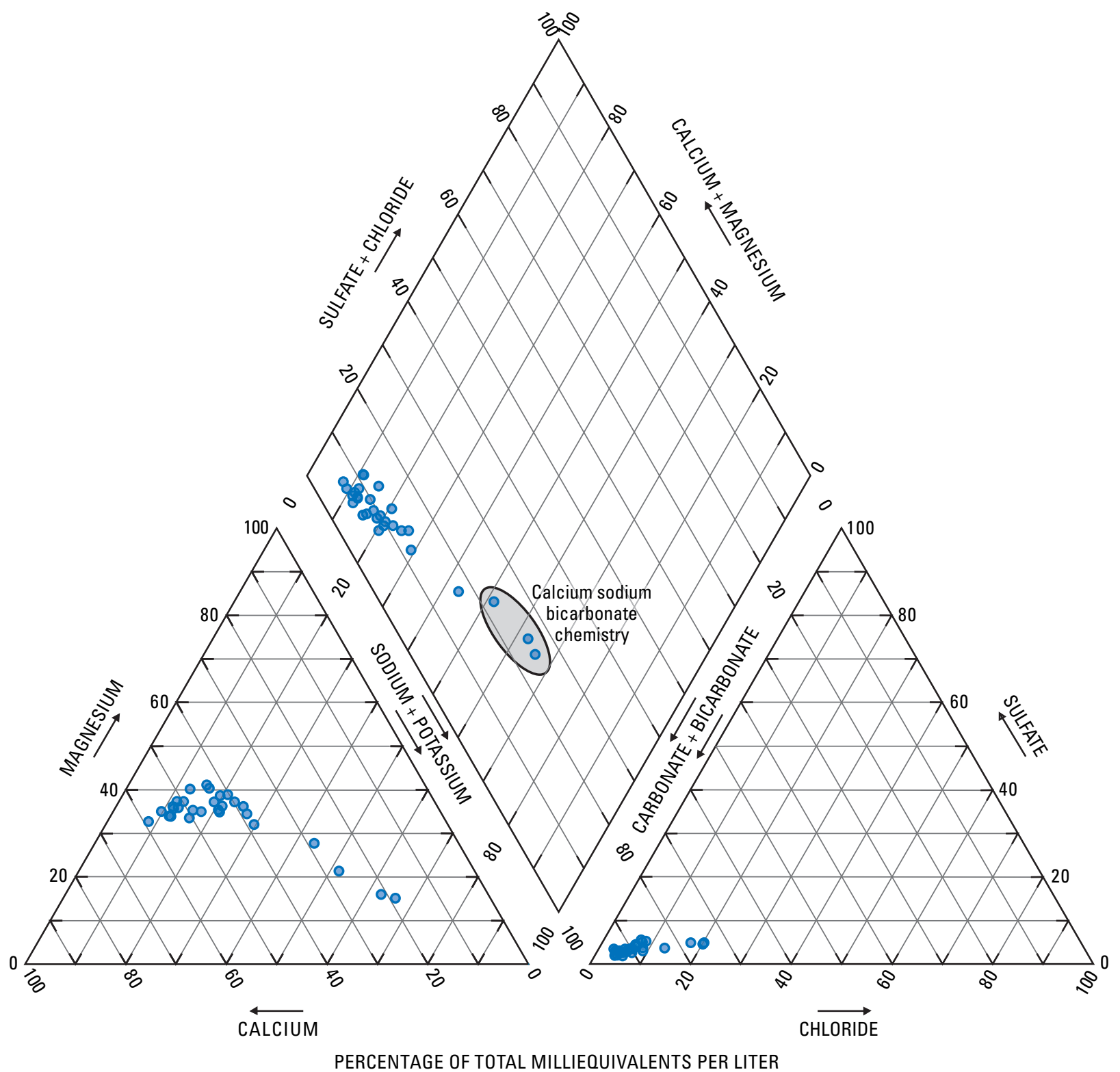

Figure 21. Relative compositions of water from springs in the Mogollon Highlands, central Arizona. 
A. Specific conductance

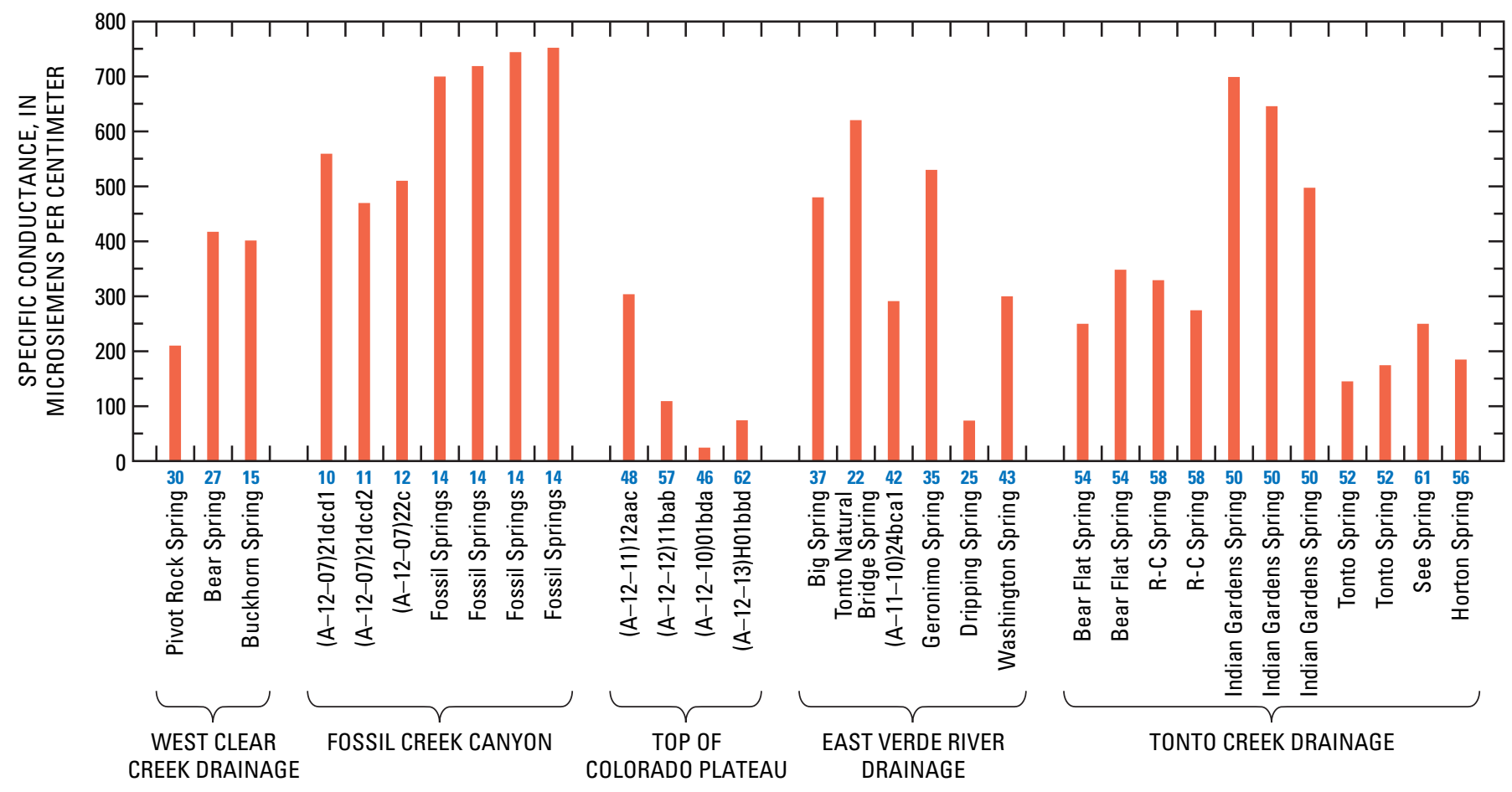

$B$. Concentrations of calcium, magnesium, and sodium

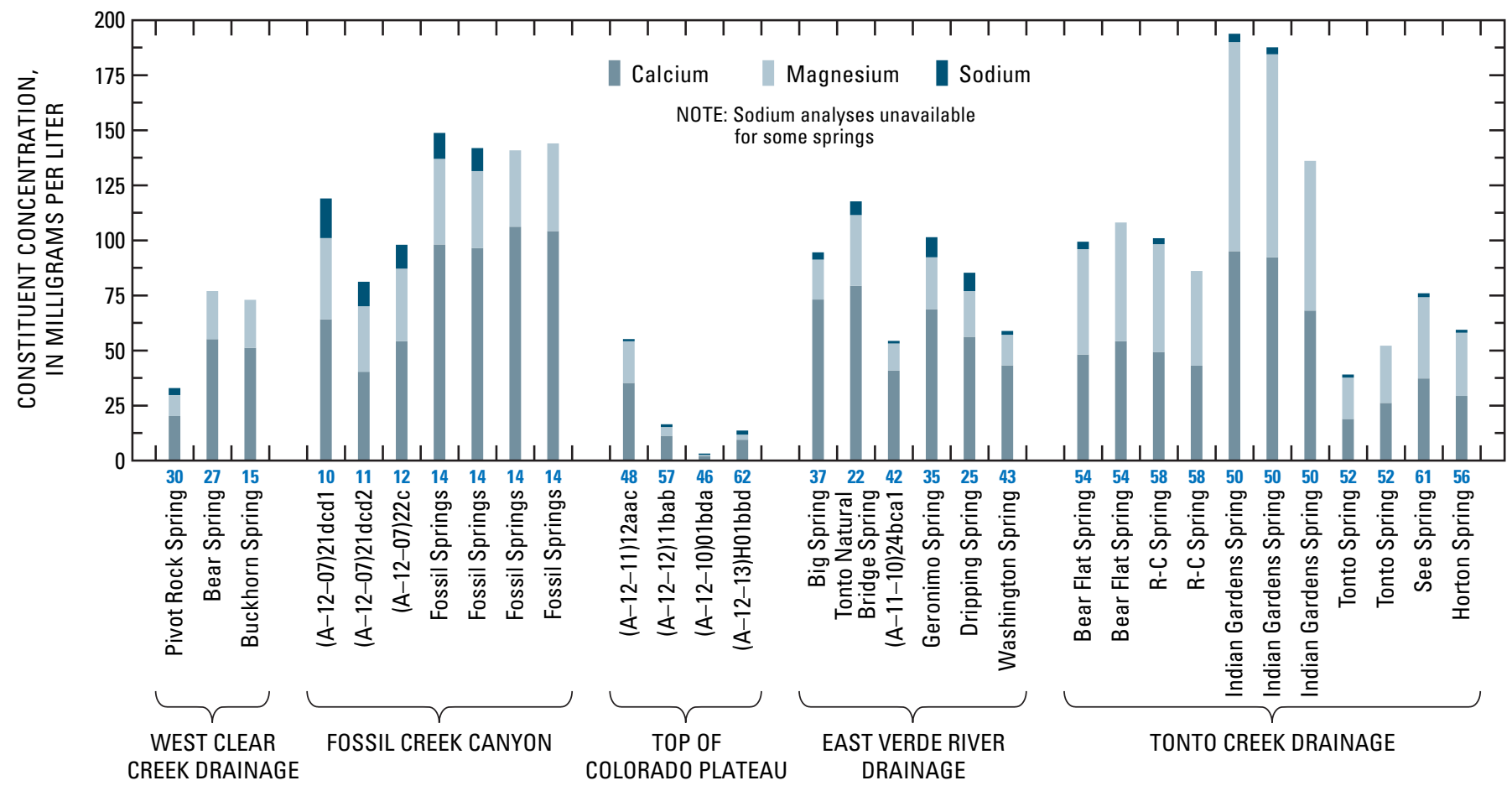

Figure 22. Chemical composition of spring waters within different drainages, Mogollon Highlands, central Arizona. A, Specific conductance; $B$, Calcium, magnesium, and sodium; $C$, Chloride and sulfate; $D$, Silica. 


\section{Hydrology of the Mogollon Highlands, Central Arizona}

C. Concentrations of chloride and sulfate

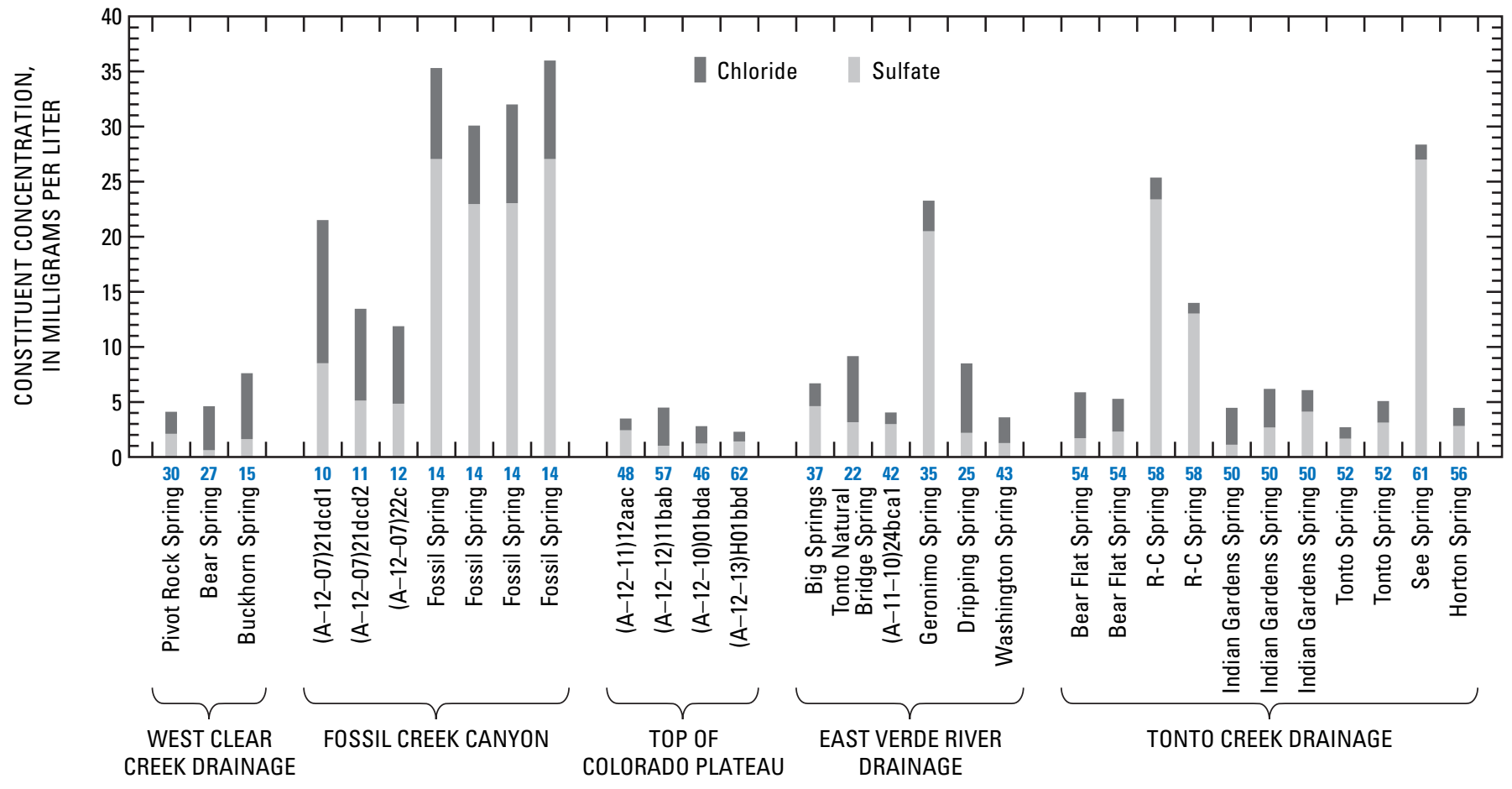

$D$. Concentration of silica

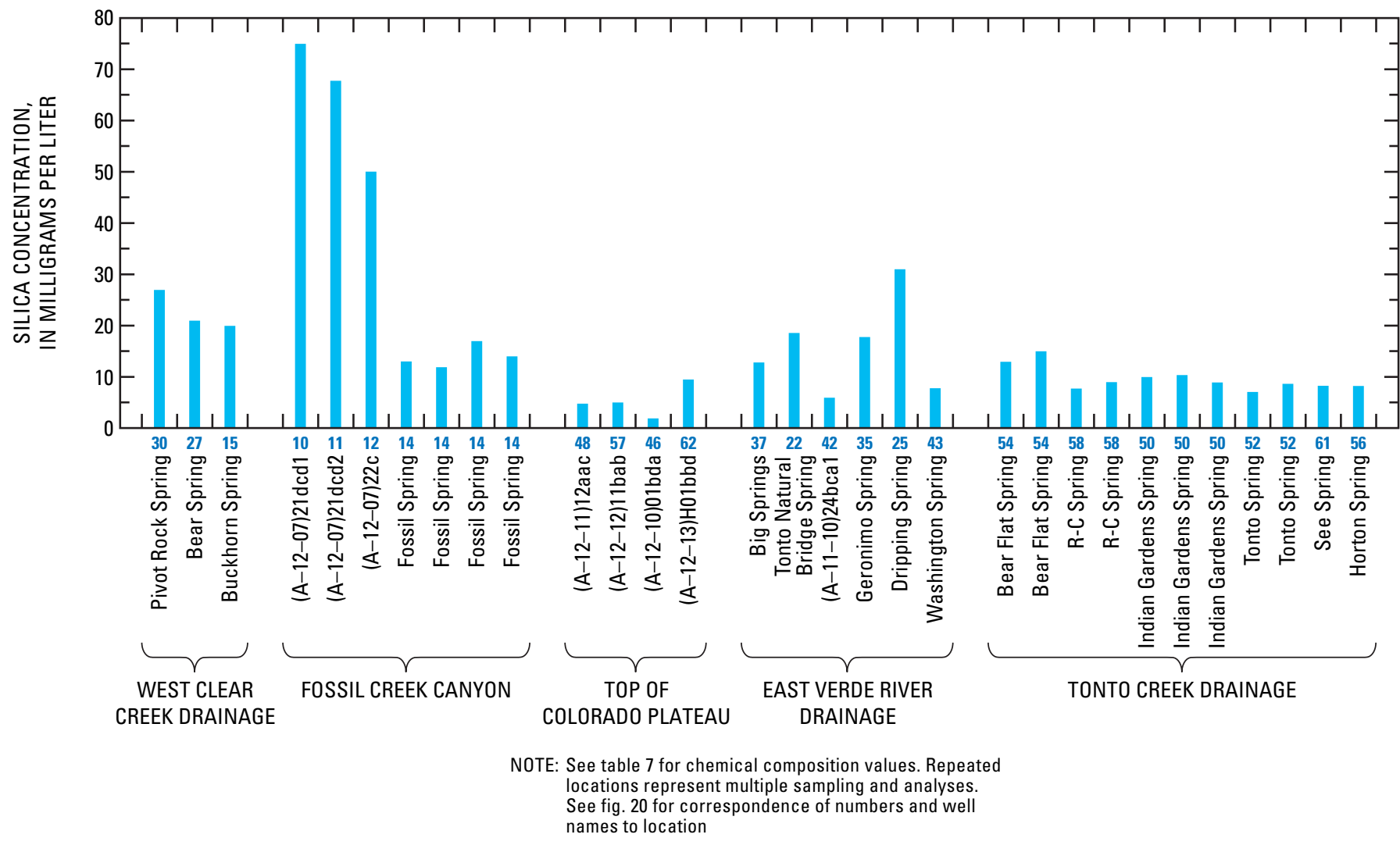

Figure 22. Continued. 
Water Chemistry 51

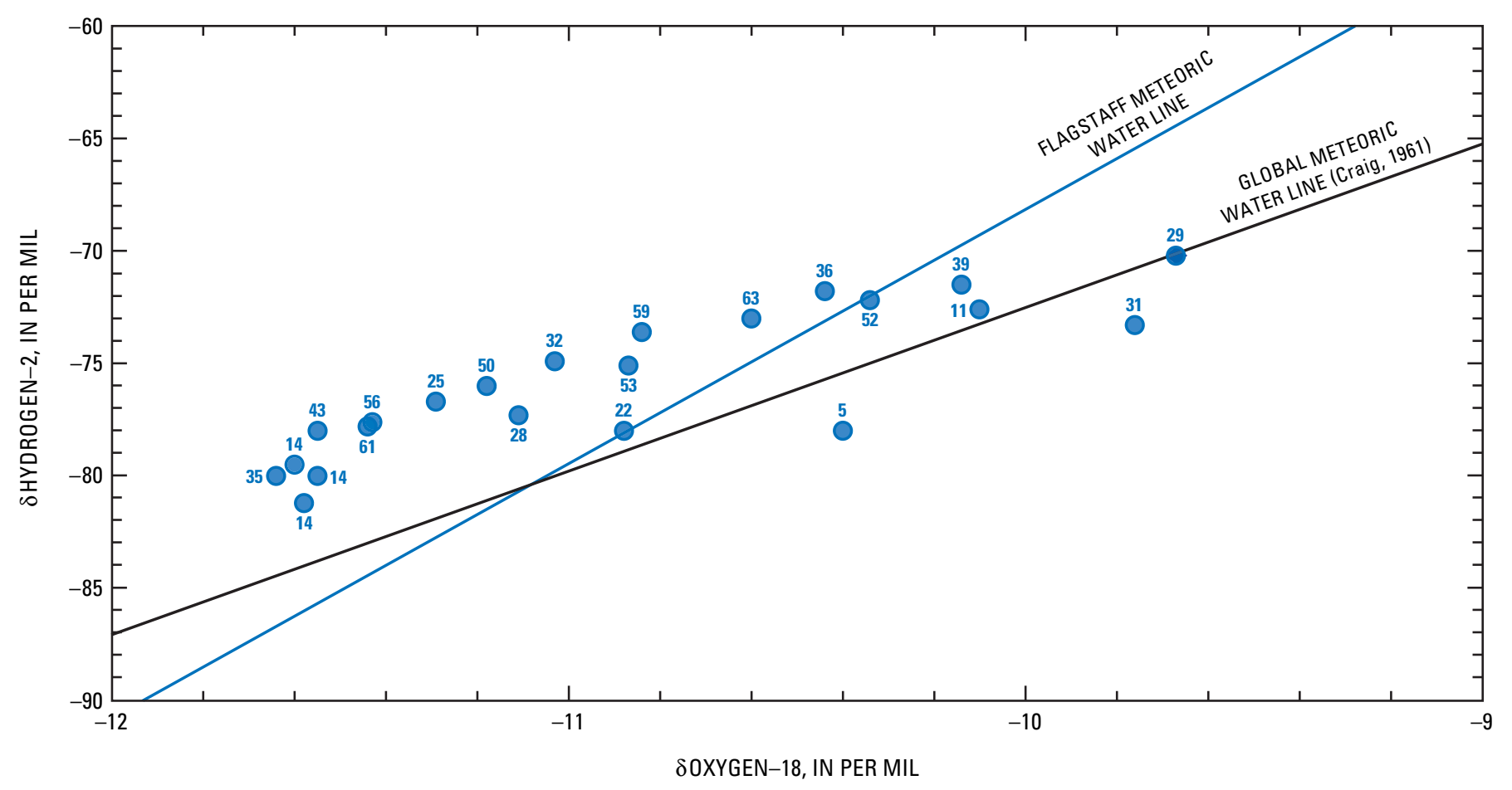

Figure 23. Isotope values for water from springs in the Mogollon Highlands, central Arizona. 


\section{Hydrology of the Mogollon Highlands, Central Arizona}

Table 8. Physical and chemical properties and chemical composition of ground water at wells in the Mogollon Highlands, central Arizona

$[\mu \mathrm{S} / \mathrm{cm}$, microsiemens per centimeter; mg/L, milligrams per liter; ANC, acid neutralizing capacity; FET, fixed endpoint titration; <, less than. Bold face numbers indicate water-depth data are available in table 6. Dashes indicate no data]

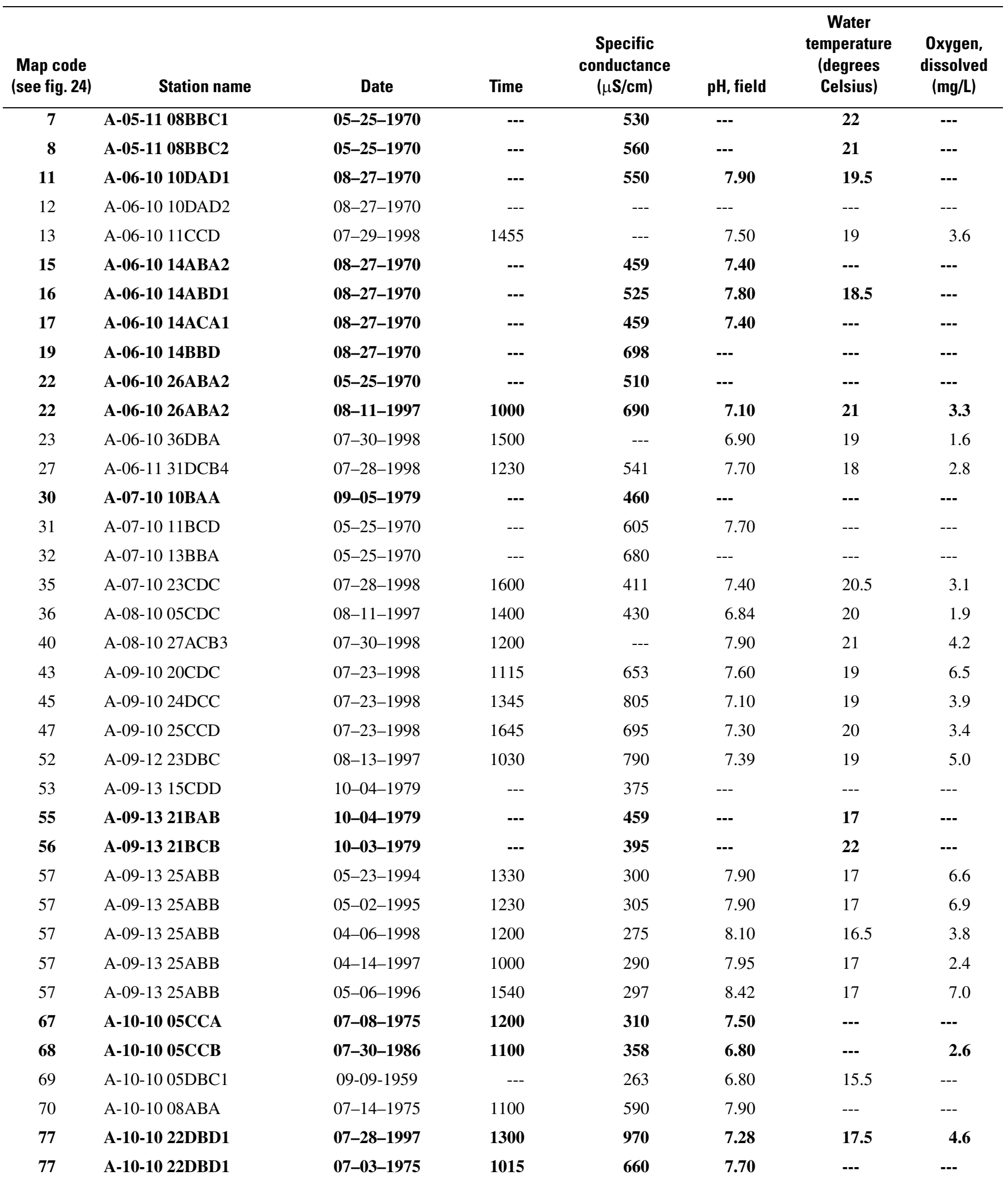


Table 8. Physical and chemical properties and chemical composition of ground water at wells in the Mogollon Highlands, central Arizona-Continued

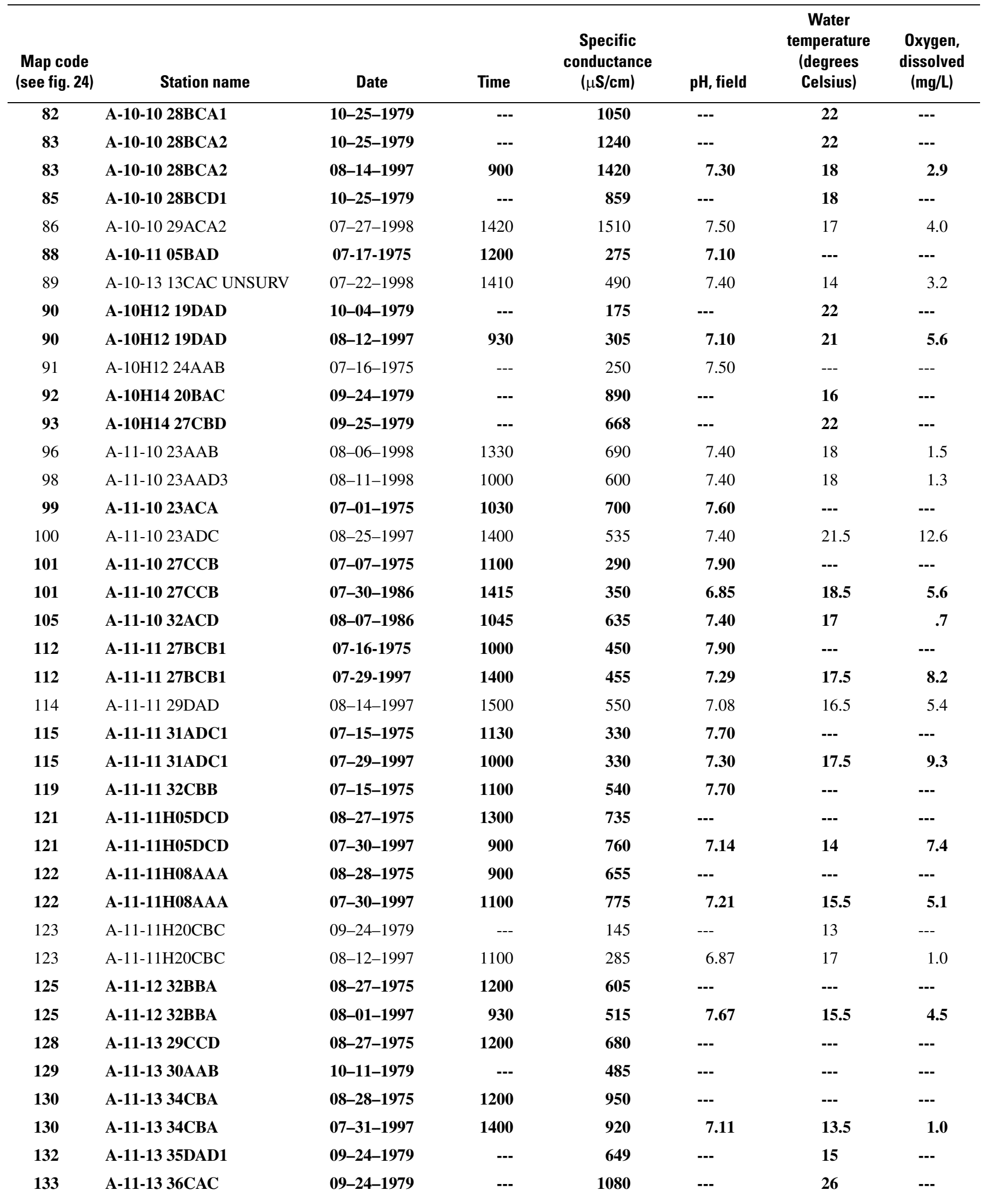




\section{Hydrology of the Mogollon Highlands, Central Arizona}

Table 8. Physical and chemical properties and chemical composition of ground water at wells in the Mogollon Highlands, central Arizona-Continued

\begin{tabular}{|c|c|c|c|c|c|c|c|c|}
\hline $\begin{array}{l}\text { Map code } \\
\text { (see fig. 24) }\end{array}$ & \multicolumn{2}{|l|}{ Station name } & Date & Time & $\begin{array}{c}\text { Specific } \\
\text { conductance } \\
(\mu \mathrm{S} / \mathrm{cm})\end{array}$ & pH, field & $\begin{array}{c}\text { Water } \\
\text { temperature } \\
\text { (degrees } \\
\text { Celsius) }\end{array}$ & $\begin{array}{c}\text { Oxygen, } \\
\text { dissolved } \\
\text { (mg/L) }\end{array}$ \\
\hline 133 & \multicolumn{2}{|l|}{ A-11-13 36CAC } & 08-12-1997 & 1400 & 1220 & 7.17 & 12.5 & 2.4 \\
\hline 134 & \multicolumn{2}{|l|}{ A-11-13 36CCD } & 07-22-1998 & 1020 & 741 & 7.10 & 13 & 2.3 \\
\hline 136 & \multicolumn{2}{|l|}{ A-11-14 14BAB } & 00-00-1959 & --- & --- & --- & --- & --- \\
\hline 137 & \multicolumn{2}{|l|}{ A-11-14 22CBD } & 08-09-1966 & --- & 107 & 7.30 & 21.8 & --- \\
\hline 138 & \multicolumn{2}{|l|}{ A-11-15 07CBB } & 08-21-1995 & 1100 & 460 & 7.54 & 11.5 & 7.2 \\
\hline 141 & \multicolumn{2}{|l|}{ A-11H10 24BDC2 } & 08-11-1998 & 1330 & 590 & 7.20 & 16 & 1.3 \\
\hline 142 & \multicolumn{2}{|l|}{ A-11H11 24CCC } & 08-13-1998 & 1030 & 570 & 7.30 & 12 & 0.66 \\
\hline 143 & \multicolumn{2}{|l|}{ A-11H11 35BBB } & 07-17-1975 & 1200 & 550 & 7.40 & --- & --- \\
\hline 148 & \multicolumn{2}{|l|}{ A-12-08 21CCC1 } & 11-07-1974 & 1200 & 515 & 8.10 & 10 & --- \\
\hline 150 & \multicolumn{2}{|l|}{ A-12-08 21CDD } & 08-19-1997 & 1430 & 520 & 7.50 & 15 & --- \\
\hline 159 & \multicolumn{2}{|l|}{ A-12-08 25ADC } & 10-17-1974 & 1000 & 555 & 8.10 & 24 & --- \\
\hline 164 & \multicolumn{2}{|l|}{ A-12-08 27BBC } & 08-25-1997 & 1200 & 570 & 7.50 & 14.5 & --- \\
\hline 171 & \multicolumn{2}{|l|}{ A-12-08 36ADD } & 11-07-1974 & 1400 & 335 & 8.10 & 8 & --- \\
\hline 174 & \multicolumn{2}{|l|}{ A-12-09 19CCC1 } & 10-17-1974 & 900 & 540 & 7.60 & 19 & --- \\
\hline 175 & \multicolumn{2}{|l|}{ A-12-09 30BBA1 } & 10-13-1974 & --- & 470 & 7.80 & 16 & --- \\
\hline 177 & \multicolumn{2}{|l|}{ A-12-09 30BBC1 } & 08-12-1998 & 1430 & 290 & 7.50 & 18 & 3.3 \\
\hline 180 & \multicolumn{2}{|l|}{ A-12-10 26CBB } & 08-13-1998 & 1400 & 440 & 7.6 & 15 & 4.46 \\
\hline 183 & \multicolumn{2}{|l|}{ A-12-15 36DDC } & 06-22-1972 & --- & 471 & 7.40 & 12 & --- \\
\hline 187 & \multicolumn{2}{|l|}{ A-12-17 32DDC } & 06-22-1972 & --- & 417 & 7.9 & --- & --- \\
\hline 187 & \multicolumn{2}{|l|}{ A-12-17 32DDC } & $10-02-1967$ & --- & 333 & --- & --- & --- \\
\hline 216 & \multicolumn{2}{|l|}{ A-14-10 02ACB } & 07-13-1978 & --- & 640 & 7.40 & --- & --- \\
\hline 223 & \multicolumn{2}{|l|}{ A-14-11 30DDD } & $10-26-1965$ & --- & 532 & 7.70 & 13 & --- \\
\hline 229 & \multicolumn{2}{|l|}{ A-15-12 31DDC } & 08-25-1995 & 1100 & 620 & 7.37 & 13 & 7.2 \\
\hline $\begin{array}{l}\text { Map code } \\
\text { (see fig. 24) }\end{array}$ & $\begin{array}{l}\text { Hardness, total } \\
\text { (mg/L as } \\
\left.\mathrm{CaCO}_{3}\right)\end{array}$ & $\begin{array}{c}\text { ANC, FET, } \\
\text { field } \\
(\mathrm{mg} / \mathrm{L} \text { as } \\
\left.\mathrm{CaCO}_{3}\right)\end{array}$ & $\begin{array}{l}\text { ANC, FET, } \\
\text { field } \\
(\mathrm{mg} / \mathrm{L} \text { as } \\
\left.\mathrm{HCO}_{3}\right)\end{array}$ & $\begin{array}{l}\text { Dissolved } \\
\text { solids, sum of } \\
\text { constituents } \\
\text { (mg/L) }\end{array}$ & $\begin{array}{l}\text { Calcium, } \\
\text { dissolved } \\
\text { (as mg/L) }\end{array}$ & $\begin{array}{l}\text { Magnesium, } \\
\text { dissolved } \\
\text { (mg/L) }\end{array}$ & $\begin{array}{c}\mathrm{Ca} / \mathrm{Mg} \\
\text { (molar) }\end{array}$ & $\begin{array}{l}\text { Sodium, } \\
\text { dissolved } \\
\text { (mg/L) }\end{array}$ \\
\hline 7 & 230 & 187 & 228 & 137 & 36 & 33 & .66 & --- \\
\hline 8 & 230 & 212 & 258 & 143 & 71 & 14 & 3.08 & --- \\
\hline 11 & 220 & 208 & 254 & 511 & 71 & 11 & 3.91 & 24 \\
\hline 12 & 600 & --- & --- & 485 & 160 & 50 & 1.89 & --- \\
\hline 13 & 200 & 177 & 216 & 400 & 55 & 14 & 2.38 & 36 \\
\hline 15 & 170 & 151 & 184 & 309 & 47 & 13 & 2.19 & --- \\
\hline 16 & 210 & 189 & 230 & 296 & 57 & 17 & 2.03 & 24 \\
\hline 17 & 170 & 185 & 226 & 244 & 47 & 13 & 2.19 & 22 \\
\hline 19 & 240 & 207 & 252 & 248 & 61 & 21 & 1.76 & 50 \\
\hline 22 & 250 & 185 & 226 & 206 & 68 & 19 & 2.20 & 42 \\
\hline 22 & 210 & 188 & 229 & 239 & 60 & 15 & 2.43 & --- \\
\hline
\end{tabular}


Table 8. Physical and chemical properties and chemical composition of ground water at wells in the Mogollon Highlands, central Arizona-Continued

\begin{tabular}{|c|c|c|c|c|c|c|c|c|}
\hline $\begin{array}{l}\text { Map code } \\
\text { (see fig. 24) }\end{array}$ & $\begin{array}{c}\text { Hardness, total } \\
(\mathrm{mg} / \mathrm{L} \text { as } \\
\left.\mathrm{CaCO}_{3}\right)\end{array}$ & $\begin{array}{c}\text { ANC, FET, } \\
\text { field } \\
\text { (mg/L as } \\
\mathrm{CaCO}_{3} \text { ) }\end{array}$ & $\begin{array}{c}\text { ANC, FET, } \\
\text { field } \\
\text { (mg/L as } \\
\mathrm{HCO}_{3} \text { ) }\end{array}$ & $\begin{array}{c}\text { Dissolved } \\
\text { solids, sum of } \\
\text { constituents } \\
\text { (mg/L) }\end{array}$ & $\begin{array}{l}\text { Calcium, } \\
\text { dissolved } \\
\text { (as mg/L) }\end{array}$ & $\begin{array}{l}\text { Magnesium, } \\
\text { dissolved } \\
\text { (mg/L) }\end{array}$ & $\begin{array}{l}\mathrm{Ca} / \mathrm{Mg} \\
\text { (molar) }\end{array}$ & $\begin{array}{c}\text { Sodium, } \\
\text { dissolved } \\
\text { (mg/L) }\end{array}$ \\
\hline 23 & 460 & --- & --- & 185 & 120 & 37 & 2.02 & 91 \\
\hline 27 & 260 & 200 & 244 & 178 & 76 & 18 & 2.56 & 35 \\
\hline 30 & --- & --- & --- & 517 & --- & --- & --. & --- \\
\hline 31 & 860 & 226 & 276 & 515 & 65 & 170 & .23 & --- \\
\hline 32 & 280 & 41 & 50 & 514 & 64 & 28 & 1.39 & --- \\
\hline 35 & 170 & 163 & 198 & 513 & 51 & 11 & 2.84 & 23 \\
\hline 36 & 200 & 217 & 265 & 565 & 55 & 15 & 2.29 & 13 \\
\hline 40 & 100 & 227 & 277 & 562 & 26 & 7.9 & 2.03 & 110 \\
\hline 43 & 280 & 278 & 339 & 576 & 91 & 13 & 4.17 & 28 \\
\hline 45 & 270 & 270 & --- & 442 & 79 & 17 & 2.79 & 59 \\
\hline 47 & 230 & 245 & 298 & 568 & 69 & 14 & 2.92 & 64 \\
\hline 52 & 300 & 281 & 343 & 593 & 67 & 31 & 1.30 & 38 \\
\hline 53 & --- & --- & --- & 719 & --- & --- & --- & --- \\
\hline 55 & --- & --- & --- & --- & --- & --- & --- & --- \\
\hline 56 & --- & --- & --- & 603 & --- & --- & --- & --- \\
\hline 57 & 140 & 123 & 150 & 573 & 48 & 4.4 & 6.62 & 6.4 \\
\hline 57 & 130 & 121 & 148 & 575 & 45 & 4.6 & 5.81 & 6.5 \\
\hline 57 & 140 & 106 & 129 & 571 & 48 & 4.6 & 6.33 & 6.9 \\
\hline 57 & 130 & 118 & 144 & 572 & 44 & 4.1 & 6.51 & 7.0 \\
\hline 57 & 130 & 135 & 150 & 573 & 45 & 4.5 & 5.99 & 6.2 \\
\hline 67 & 120 & 121 & 148 & --- & 31 & 10 & 1.88 & 16 \\
\hline 68 & 150 & 127 & 155 & --- & 38 & 13 & 1.77 & 13 \\
\hline 69 & 110 & --- & --- & 168 & 26 & 10 & 1.58 & --- \\
\hline 70 & 250 & 161 & 196 & --- & 57 & 25 & 1.38 & 20 \\
\hline 77 & 440 & 327 & 399 & --- & 110 & 39 & 1.73 & 43 \\
\hline 77 & 280 & 286 & 349 & --- & 71 & 26 & 1.66 & 34 \\
\hline 82 & --- & --- & --- & --- & --- & --- & -- & --- \\
\hline 83 & --- & --- & --- & --- & --- & --- & -- & --- \\
\hline 83 & 520 & 562 & 685 & --- & 120 & $\mathbf{5 0}$ & 1.51 & 120 \\
\hline 85 & --- & -- & --- & 730 & -- & --. & -- & --- \\
\hline 86 & 640 & 441 & 538 & --- & 160 & 61 & 1.56 & 85 \\
\hline 88 & 110 & 128 & 156 & 171 & 30 & 9.4 & 1.94 & 13 \\
\hline 89 & 240 & 253 & 309 & --- & 61 & 22 & 1.68 & 5.9 \\
\hline 90 & --- & --- & --- & --- & --- & --- & --- & --- \\
\hline 90 & 120 & 127 & 154 & --- & 27 & 13 & 1.31 & 20 \\
\hline 91 & 170 & 170 & 207 & --- & 48 & 12 & 2.43 & 3.4 \\
\hline 92 & --- & --- & --- & --- & --- & --- & --- & --- \\
\hline 93 & --- & --- & --- & --- & --- & --. & --- & --. \\
\hline 96 & 320 & 288 & 351 & --- & 92 & 22 & 2.52 & 18 \\
\hline
\end{tabular}




\section{Hydrology of the Mogollon Highlands, Central Arizona}

Table 8. Physical and chemical properties and chemical composition of ground water at wells in the Mogollon Highlands, central Arizona-Continued

\begin{tabular}{|c|c|c|c|c|c|c|c|c|}
\hline $\begin{array}{c}\text { Map code } \\
\text { (see fig. 24) }\end{array}$ & $\begin{array}{l}\text { Hardness, total } \\
\text { (mg//L as } \\
\left.\mathrm{CaCO}_{3}\right)\end{array}$ & $\begin{array}{c}\text { ANC, FET, } \\
\text { field } \\
\text { (mg/L as } \\
\mathrm{CaCO}_{3} \text { ) }\end{array}$ & $\begin{array}{c}\text { ANC, FET, } \\
\text { field } \\
\text { (mg/L as } \\
\mathrm{HCO}_{3} \text { ) }\end{array}$ & $\begin{array}{c}\text { Dissolved } \\
\text { solids, sum of } \\
\text { constituents } \\
\text { (mg/L) }\end{array}$ & $\begin{array}{l}\text { Calcium, } \\
\text { dissolved } \\
\text { (as mg/L) }\end{array}$ & $\begin{array}{l}\text { Magnesium, } \\
\text { dissolved } \\
(\mathrm{mg} / \mathrm{L})\end{array}$ & $\begin{array}{l}\mathrm{Ca} / \mathrm{Mg} \\
\text { (molar) }\end{array}$ & $\begin{array}{c}\text { Sodium, } \\
\text { dissolved } \\
(\mathrm{mg} / \mathrm{L})\end{array}$ \\
\hline 98 & 290 & 285 & 347 & --- & 80 & 21 & 2.33 & 17 \\
\hline 99 & 180 & 154 & 188 & --. & 40 & 19 & 1.28 & 20 \\
\hline 100 & 240 & 263 & 320 & --- & 71 & 14 & 3.02 & 17 \\
\hline 101 & 130 & 115 & 140 & --- & 29 & 15 & 1.17 & 20 \\
\hline 101 & 110 & 112 & 136 & --. & 24 & 12 & 1.21 & 18 \\
\hline 105 & 280 & 293 & 357 & --- & 69 & 27 & 1.55 & 16 \\
\hline 112 & 220 & 224 & 273 & 253 & 52 & 21 & 1.50 & 6.4 \\
\hline 112 & 230 & 228 & --- & 268 & 63 & 18 & 2.13 & 5.5 \\
\hline 114 & 250 & 277 & 337 & --- & 78 & 14 & 3.48 & 14 \\
\hline 115 & 140 & 159 & 194 & --. & 34 & 13 & 1.59 & 14 \\
\hline 115 & 140 & 161 & 196 & --- & 36 & 13 & 1.72 & 14 \\
\hline 119 & 230 & 261 & 318 & --- & 65 & 17 & 2.32 & 16 \\
\hline 121 & 410 & 189 & 230 & --- & --- & 29 & 2.41 & 2.6 \\
\hline 121 & 400 & 422 & 515 & --- & 120 & 24 & 3.03 & 3.4 \\
\hline 122 & 370 & 147 & 179 & --- & 120 & 16 & 4.55 & 3.0 \\
\hline 122 & 390 & 373 & 455 & --- & 130 & 16 & 4.77 & 5.4 \\
\hline 123 & --- & --- & --- & --- & --- & --- & --- & --- \\
\hline 123 & 62 & 44 & 54 & --- & 19 & 3.8 & 2.98 & 12 \\
\hline 125 & 290 & 215 & 262 & --- & 67 & 29 & 1.41 & 16 \\
\hline 125 & 290 & 316 & 385 & --- & 69 & 29 & 1.44 & 16 \\
\hline 128 & 360 & 212 & 258 & --- & 110 & 20 & 3.34 & 8.0 \\
\hline 129 & --- & --- & --- & --- & --- & --- & --- & --. \\
\hline 130 & 470 & 157 & 192 & --- & 130 & 35 & 2.25 & 22 \\
\hline 130 & 460 & 380 & 463 & --- & 130 & 31 & 2.62 & 19 \\
\hline 132 & --- & --- & --- & --- & --- & --- & --- & --- \\
\hline 133 & --- & --- & --- & --- & --- & --- & --- & --- \\
\hline 133 & 570 & 254 & 309 & --- & 190 & 23 & 5.06 & 48 \\
\hline 134 & 400 & 370 & 451 & --- & 100 & 33 & 1.91 & 17 \\
\hline 136 & 35 & 28 & 34 & --- & 9.0 & 3.0 & 1.82 & 1.0 \\
\hline 137 & 52 & 54 & 66 & --- & 14 & 4.1 & 2.07 & --- \\
\hline 138 & 250 & 260 & 316 & --- & 54 & 28 & 1.17 & 1.6 \\
\hline 141 & 330 & 334 & --- & 408 & 78 & 33 & 1.44 & 2.6 \\
\hline 142 & 310 & 307 & --- & 329 & 100 & 15 & 3.99 & 4.8 \\
\hline 143 & 290 & 270 & 329 & 286 & 83 & 20 & 2.52 & 2.2 \\
\hline 148 & --- & --- & --- & --- & --- & --- & --- & --. \\
\hline 150 & 260 & 253 & 309 & --- & 66 & 23 & 1.76 & 8.4 \\
\hline 159 & --- & --- & --- & --- & --- & --- & --- & --- \\
\hline 164 & 290 & 312 & 380 & --- & 67 & 29 & 1.42 & 11 \\
\hline 171 & --- & --- & --- & --- & --- & --- & --- & --- \\
\hline
\end{tabular}


Table 8. Physical and chemical properties and chemical composition of ground water at wells in the Mogollon Highlands, central Arizona-Continued

\begin{tabular}{|c|c|c|c|c|c|c|c|c|}
\hline $\begin{array}{l}\text { Map code } \\
\text { (see fig. 24) }\end{array}$ & $\begin{array}{l}\text { Hardness, total } \\
(\mathrm{mg} / \mathrm{L} \text { as } \\
\left.\mathrm{CaCO}_{3}\right)\end{array}$ & $\begin{array}{c}\text { ANC, FET, } \\
\text { field } \\
\text { (mg/L as } \\
\mathrm{CaCO}_{3} \text { ) }\end{array}$ & $\begin{array}{c}\text { ANC, FET, } \\
\text { field } \\
\text { (mg/L as } \\
\left.\mathrm{HCO}_{3}\right)\end{array}$ & $\begin{array}{l}\text { Dissolved } \\
\text { solids, sum of } \\
\text { constituents } \\
\text { (mg/L) }\end{array}$ & $\begin{array}{l}\text { Calcium, } \\
\text { dissolved } \\
\text { (as mg/L) }\end{array}$ & $\begin{array}{l}\text { Magnesium, } \\
\text { dissolved } \\
\text { (mg/L) }\end{array}$ & $\begin{array}{l}\mathrm{Ca} / \mathrm{Mg} \\
\text { (molar) }\end{array}$ & $\begin{array}{c}\text { Sodium, } \\
\text { dissolved } \\
\text { (mg/L) }\end{array}$ \\
\hline 174 & --- & --- & --- & --- & --- & --- & --- & --- \\
\hline 175 & --- & --- & --- & --- & --- & --- & --- & --- \\
\hline 177 & 150 & 148 & 181 & --- & 36 & 13 & 1.66 & 2.8 \\
\hline 180 & 240 & 235 & --- & 242 & 63 & 19 & 2.03 & 2.0 \\
\hline 183 & 250 & 256 & 312 & --- & 52 & 29 & 1.09 & 2.3 \\
\hline 187 & 240 & 176 & 214 & --- & 60 & 22 & 1.65 & --- \\
\hline 187 & 170 & 141 & 172 & --- & 32 & 23 & .84 & 3.0 \\
\hline 216 & 330 & 290 & 350 & --- & 85 & 29 & 1.78 & 4.1 \\
\hline 223 & 290 & 294 & 358 & --- & 74 & 26 & 1.73 & --- \\
\hline 229 & 340 & 314 & 383 & --- & 80 & 33 & 1.47 & 5.0 \\
\hline
\end{tabular}

\begin{tabular}{|c|c|c|c|c|c|c|}
\hline $\begin{array}{l}\text { Map code } \\
\text { (see fig. 24) }\end{array}$ & $\begin{array}{l}\mathrm{Ca} / \mathrm{Na} \\
\text { (molar) }\end{array}$ & $\begin{array}{l}\text { Potassium, dissolved } \\
(\mathrm{mg} / \mathrm{L})\end{array}$ & $\begin{array}{c}\text { Sulfate, dissolved } \\
(\mathrm{mg} / \mathrm{L})\end{array}$ & $\begin{array}{c}\text { Chloride, dissolved } \\
(\mathrm{mg} / \mathrm{L})\end{array}$ & $\begin{array}{l}\text { Fluoride, dissolved } \\
\qquad(\mathrm{mg} / \mathrm{L})\end{array}$ & $\begin{array}{c}\text { Silica, dissolved } \\
(\mathrm{mg} / \mathrm{L})\end{array}$ \\
\hline 7 & --- & --- & 40 & 34 & .50 & 18 \\
\hline 8 & --- & --- & 30 & 22 & .40 & 18 \\
\hline 11 & 1.70 & 1.2 & 24 & 32 & .40 & 18 \\
\hline 12 & --- & --- & 2,700 & 24 & 3.0 & --- \\
\hline 13 & .87 & 1.4 & 33 & 31 & .51 & 21 \\
\hline 15 & --- & --- & 11 & 40 & .30 & 9.1 \\
\hline 16 & 1.36 & 1.8 & 11 & 41 & .30 & 11 \\
\hline 17 & 1.23 & 1.6 & 11 & 40 & .30 & 9.1 \\
\hline 19 & .70 & 1.2 & 79 & 36 & .30 & 30 \\
\hline 22 & .93 & 1.6 & 87 & 57 & .48 & 20 \\
\hline 22 & --- & --- & 34 & 32 & .40 & 17 \\
\hline 23 & .77 & 1.5 & 240 & 94 & .66 & 26 \\
\hline 27 & 1.25 & 1.5 & 59 & 39 & .37 & 19 \\
\hline 30 & --- & --- & --- & --- & .50 & --- \\
\hline 31 & --- & --- & 15 & 48 & .30 & 16 \\
\hline 32 & --- & --- & 16 & 72 & .20 & 29 \\
\hline 35 & 1.27 & 1.5 & 9.6 & 24 & .38 & 16 \\
\hline 36 & 2.41 & 1.9 & 11 & 10 & .13 & 21 \\
\hline 40 & .13 & 3.0 & 14 & 59 & .56 & 26 \\
\hline 43 & 1.86 & .36 & 16 & 33 & .21 & 22 \\
\hline 45 & .77 & 2.0 & 15 & 81 & .60 & 21 \\
\hline 47 & .62 & 2.5 & 14 & 83 & .71 & 20 \\
\hline 52 & 1.02 & 2.3 & 19 & 43 & .75 & 20 \\
\hline 53 & --- & --- & --- & --- & .40 & --- \\
\hline 55 & --- & --- & -- & --- & .40 & --- \\
\hline 56 & --- & --- & --- & --- & .40 & --- \\
\hline
\end{tabular}




\section{Hydrology of the Mogollon Highlands, Central Arizona}

Table 8. Physical and chemical properties and chemical composition of ground water at wells in the Mogollon Highlands, central Arizona-Continued

\begin{tabular}{|c|c|c|c|c|c|c|}
\hline $\begin{array}{l}\text { Map code } \\
\text { (see fig. 24) }\end{array}$ & $\begin{array}{l}\mathrm{Ca} / \mathrm{Na} \\
\text { (molar) }\end{array}$ & $\begin{array}{l}\text { Potassium, dissolved } \\
(\mathrm{mg} / \mathrm{L})\end{array}$ & $\begin{array}{c}\text { Sulfate, dissolved } \\
(\mathrm{mg} / \mathrm{L})\end{array}$ & $\begin{array}{c}\text { Chloride, dissolved } \\
(\mathrm{mg} / \mathrm{L})\end{array}$ & $\begin{array}{c}\text { Fluoride, dissolved } \\
(\mathrm{mg} / \mathrm{L})\end{array}$ & $\begin{array}{c}\text { Silica, dissolved } \\
(\mathrm{mg} / \mathrm{L})\end{array}$ \\
\hline 57 & 4.30 & .70 & 2.6 & 7.3 & .20 & 25 \\
\hline 57 & 3.95 & .76 & 2.1 & 9.3 & .19 & 24 \\
\hline 57 & 3.99 & .80 & 1.9 & 9.4 & .20 & 23 \\
\hline 57 & 3.61 & .90 & 1.9 & 9.2 & .20 & 24 \\
\hline 57 & 4.13 & .90 & 1.9 & 9.4 & .27 & 24 \\
\hline 67 & 1.11 & .40 & 10 & 8.5 & 1.0 & 36 \\
\hline 68 & 1.68 & .7 & 21 & 9.4 & .80 & 30 \\
\hline 69 & --- & --- & 1.9 & 8 & 1.4 & 34 \\
\hline 70 & 1.63 & .70 & 7.7 & 17 & .20 & 28 \\
\hline 77 & 1.47 & 1.3 & 81 & 64 & .24 & 28 \\
\hline 77 & 1.20 & 1 & 32 & 17 & .30 & 26 \\
\hline 82 & --- & --- & --- & --- & .50 & --- \\
\hline 83 & -- & --- & --- & --- & 1.0 & --- \\
\hline 83 & .61 & .26 & 70 & 90 & .74 & 34 \\
\hline 85 & --- & --. & --- & --- & .30 & --- \\
\hline 86 & 1.05 & 0.3 & 61 & 180 & .37 & 30 \\
\hline 88 & .36 & .30 & 3.1 & 5.2 & 1.3 & 31 \\
\hline 89 & 5.92 & 1.2 & 11 & 3.4 & .16 & 13 \\
\hline 90 & --- & --. & --. & --- & .50 & --- \\
\hline 90 & .77 & .35 & 8.2 & 10 & 2.2 & 35 \\
\hline 91 & 8.10 & .7 & 1.7 & 4.2 & .10 & 13 \\
\hline 92 & --- & --- & --- & --- & .30 & --- \\
\hline 93 & --- & --- & --- & --- & .30 & --- \\
\hline 96 & 2.86 & 2.0 & 7.8 & 41 & .19 & 28 \\
\hline 98 & 2.63 & 1.9 & 4.9 & 15 & .33 & 30 \\
\hline 99 & 1.15 & 1.5 & 5.5 & 35 & .20 & 27 \\
\hline 100 & 2.38 & 1.4 & .71 & 14 & .32 & 28 \\
\hline 101 & .83 & .6 & 25 & 12 & .60 & 32 \\
\hline 101 & .76 & .4 & 12 & 6.8 & .60 & 29 \\
\hline 105 & 2.47 & 1 & 6.0 & 15 & .40 & 29 \\
\hline 112 & 4.66 & .9 & 2.2 & 7.6 & .2 & 24 \\
\hline 112 & 1.37 & .94 & .89 & 9.1 & .19 & 29 \\
\hline 114 & 3.23 & .65 & 2.6 & 9.4 & .44 & 26 \\
\hline 115 & 1.39 & .5 & 5.4 & 5.0 & .70 & 23 \\
\hline 115 & 1.46 & .39 & 6.5 & 5.4 & .63 & 24 \\
\hline 119 & 2.33 & .7 & 11 & 8.2 & .30 & 23 \\
\hline 121 & 25.21 & .9 & 4.1 & 3.3 & .10 & 8.6 \\
\hline 121 & 20.24 & .7 & 3.8 & 2.9 & .10 & 9.5 \\
\hline 122 & 22.94 & .9 & 3.7 & 4.4 & .10 & 8.1 \\
\hline 122 & 13.90 & .68 & 7.7 & 14 & $<.10$ & 8.9 \\
\hline
\end{tabular}


Table 8. Physical and chemical properties and chemical composition of ground water at wells in the Mogollon Highlands, central Arizona-Continued

\begin{tabular}{|c|c|c|c|c|c|c|}
\hline $\begin{array}{l}\text { Map code } \\
\text { (see fig. 24) }\end{array}$ & $\begin{array}{l}\mathrm{Ca} / \mathrm{Na} \\
\text { (molar) }\end{array}$ & $\begin{array}{c}\text { Potassium, dissolved } \\
(\mathrm{mg} / \mathrm{L})\end{array}$ & $\begin{array}{c}\text { Sulfate, dissolved } \\
(\mathrm{mg} / \mathrm{L})\end{array}$ & $\begin{array}{c}\text { Chloride, dissolved } \\
(\mathrm{mg} / \mathrm{L})\end{array}$ & $\begin{array}{c}\text { Fluoride, dissolved } \\
(\mathrm{mg} / \mathrm{L})\end{array}$ & $\begin{array}{c}\text { Silica, dissolved } \\
\text { (mg/L) }\end{array}$ \\
\hline 123 & --- & --- & --- & --- & .40 & --- \\
\hline 123 & .91 & 28 & 13 & 25 & .14 & 29 \\
\hline 125 & 2.44 & .93 & .95 & 8.8 & .58 & 31 \\
\hline 125 & 2.47 & 1.2 & 1.3 & 5.0 & .40 & 29 \\
\hline 128 & 7.89 & 1 & 15 & 6.5 & .20 & 7.9 \\
\hline 129 & --- & --- & --- & --- & .20 & --- \\
\hline 130 & 3.39 & 2 & 160 & 16 & .10 & 9.3 \\
\hline 130 & 3.97 & 1.5 & 56 & 45 & .16 & 11 \\
\hline 132 & --- & --- & --- & --- & .40 & --- \\
\hline 133 & --- & --- & --- & --- & .70 & --- \\
\hline 133 & 2.26 & 4.0 & 380 & 14 & .19 & 15 \\
\hline 134 & 3.44 & 1.4 & 44 & 13 & .14 & 9.6 \\
\hline 136 & 5.16 & --- & 10 & 10 & .50 & --- \\
\hline 137 & --- & --- & 1.0 & 2.0 & --- & 10 \\
\hline 138 & 19.36 & .4 & .40 & 1.7 & .10 & 7.3 \\
\hline 141 & 17.2 & 1.1 & 4.9 & 2.4 & .12 & 7.8 \\
\hline 142 & 11.92 & .65 & 7.0 & 3.9 & $<.1$ & 13 \\
\hline 143 & 21.64 & .9 & 5.5 & 3.9 & .1 & 8.6 \\
\hline 148 & --- & --- & --- & --- & --- & --- \\
\hline 150 & 4.54 & .64 & 6.6 & 8.1 & .12 & 22 \\
\hline 159 & --- & --- & --- & --- & .40 & --- \\
\hline 164 & 3.39 & .97 & 5.2 & .81 & .28 & 23 \\
\hline 171 & --- & --- & --- & --- & --- & --- \\
\hline 174 & --- & --. & --. & --. & .24 & --. \\
\hline 175 & --- & --- & --- & --- & .23 & --- \\
\hline 177 & 7.51 & .59 & 1.2 & 1.9 & .16 & 13 \\
\hline 180 & 17.76 & .88 & 4.6 & 1.9 & $<.1$ & 8.74 \\
\hline 183 & 12.97 & .7 & 3.7 & 3.1 & .10 & 8.3 \\
\hline 187 & --- & --- & 9 & 4 & --- & --- \\
\hline 187 & 6.12 & --- & 8.0 & 4.0 & .10 & --- \\
\hline 216 & 11.89 & .8 & 7.2 & 12 & .10 & 9.4 \\
\hline 223 & --- & --- & 1.0 & 6.5 & .10 & --- \\
\hline 229 & 9.18 & .8 & 11 & 6.9 & .10 & 8.9 \\
\hline
\end{tabular}




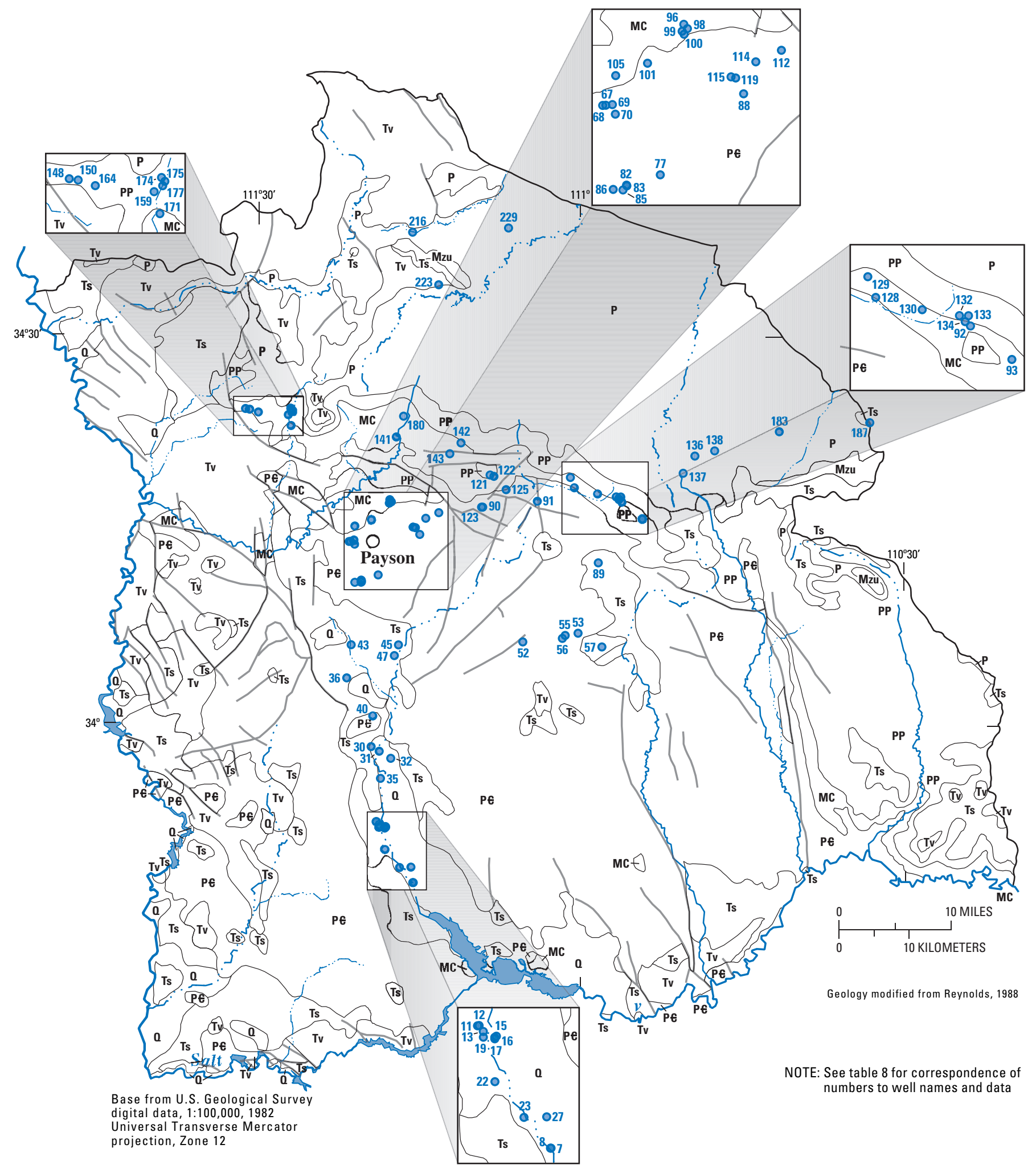

Figure 24. Wells for which chemical data are available, Mogollon Highlands, central Arizona. 


\section{EXPLANATION}

\begin{tabular}{|c|c|}
\hline 0 & SURFICIAL DEPOSITS, MOSTLY ALLUVIUM-Holocene to Middle Pleistocene \\
\hline Ts & SEDIMENTARY ROCKS —Pliocene to Middle Miocene \\
\hline Tv & VOLCANIC ROCKS—Pliocene to Middle Miocene \\
\hline Mzu & SEDIMENTARY ROCKS, UNDIFFERENTIATED_Cretaceous \\
\hline $\mathbf{P}$ & SEDIMENTARY ROCKS - Permian (Kaibab Formation and Coconino Sandstone) \\
\hline PP & $\begin{array}{l}\text { SEDIMENTARY ROCKS-Permian and Pennsylvanian (Schnebly Hill Formation, } \\
\text { Supai Formation, and Naco Formation) }\end{array}$ \\
\hline MC & $\begin{array}{l}\text { SEDIMENTARY ROCKS-Mississippian to Cambrian (Redwall Limestone, Martin Formation, } \\
\text { and Tapeats Sandstone) }\end{array}$ \\
\hline PE & PROTEROZOIC ROCKS \\
\hline & FAULT \\
\hline $\begin{array}{c}229 \\
0\end{array}$ & WELL AND WELL IDENTIFIER \\
\hline
\end{tabular}

Figure 24. Continued. 
A. Specific conductance

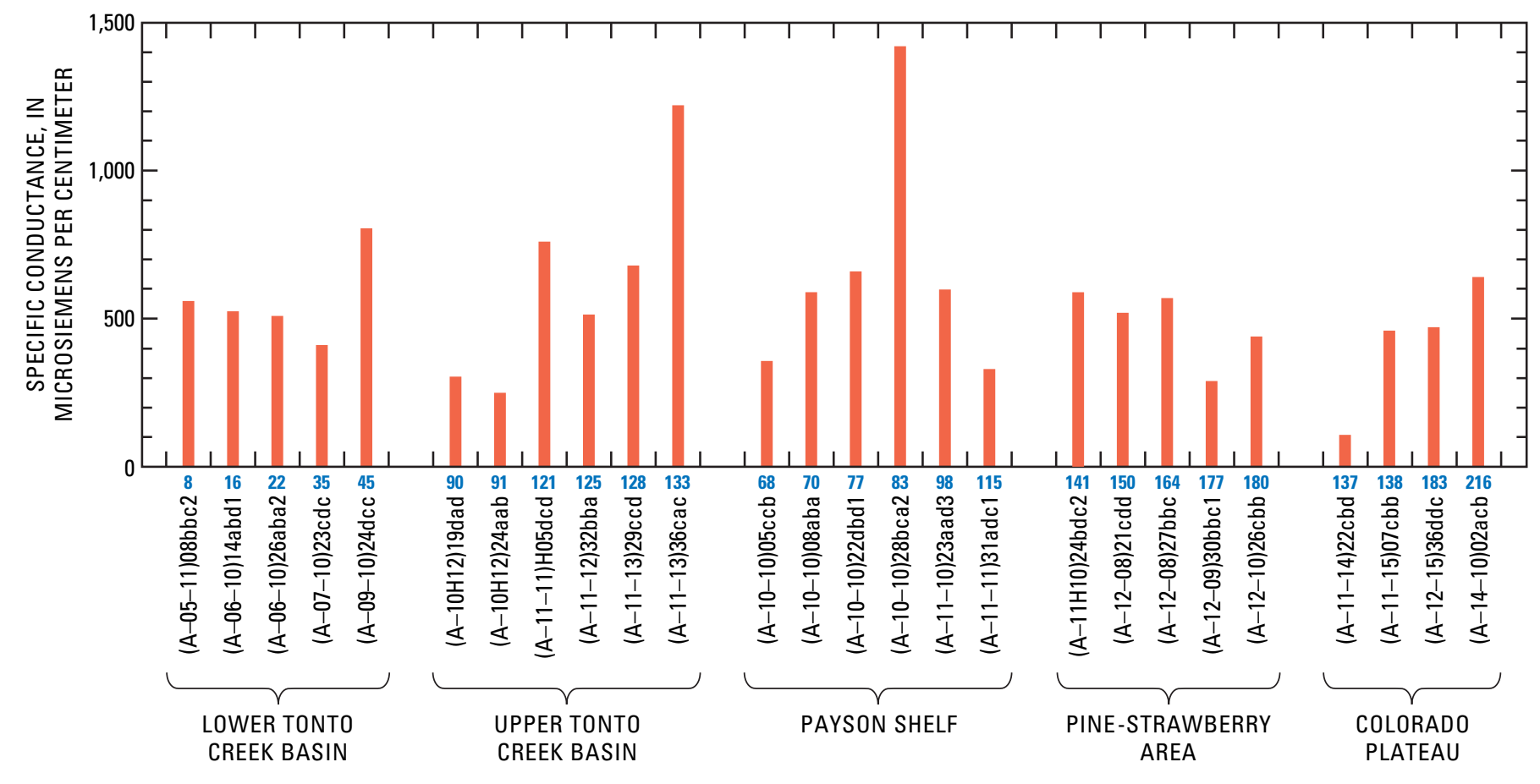

$B$. Concentrations of calcium, magnesium, and sodium

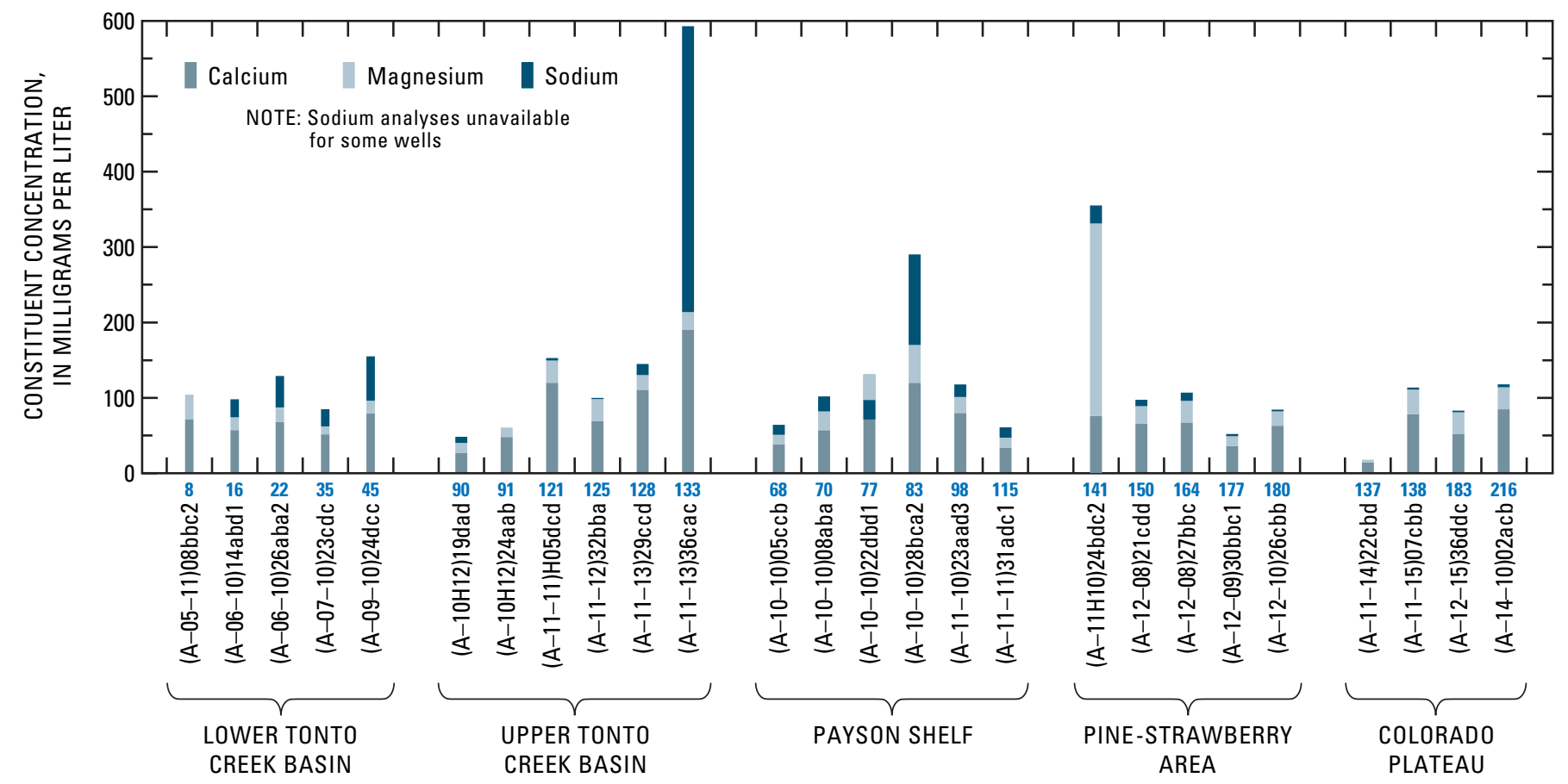

Figure 25. Chemical composition of waters from wells in various locations, Mogollon Highlands, central Arizona. $A$, Specific conductance; $B$, Calcium, magnesium, and sodium; $C$, Chloride and sulfate; $D$, Silica. 
C. Concentrations of chloride and sulfate

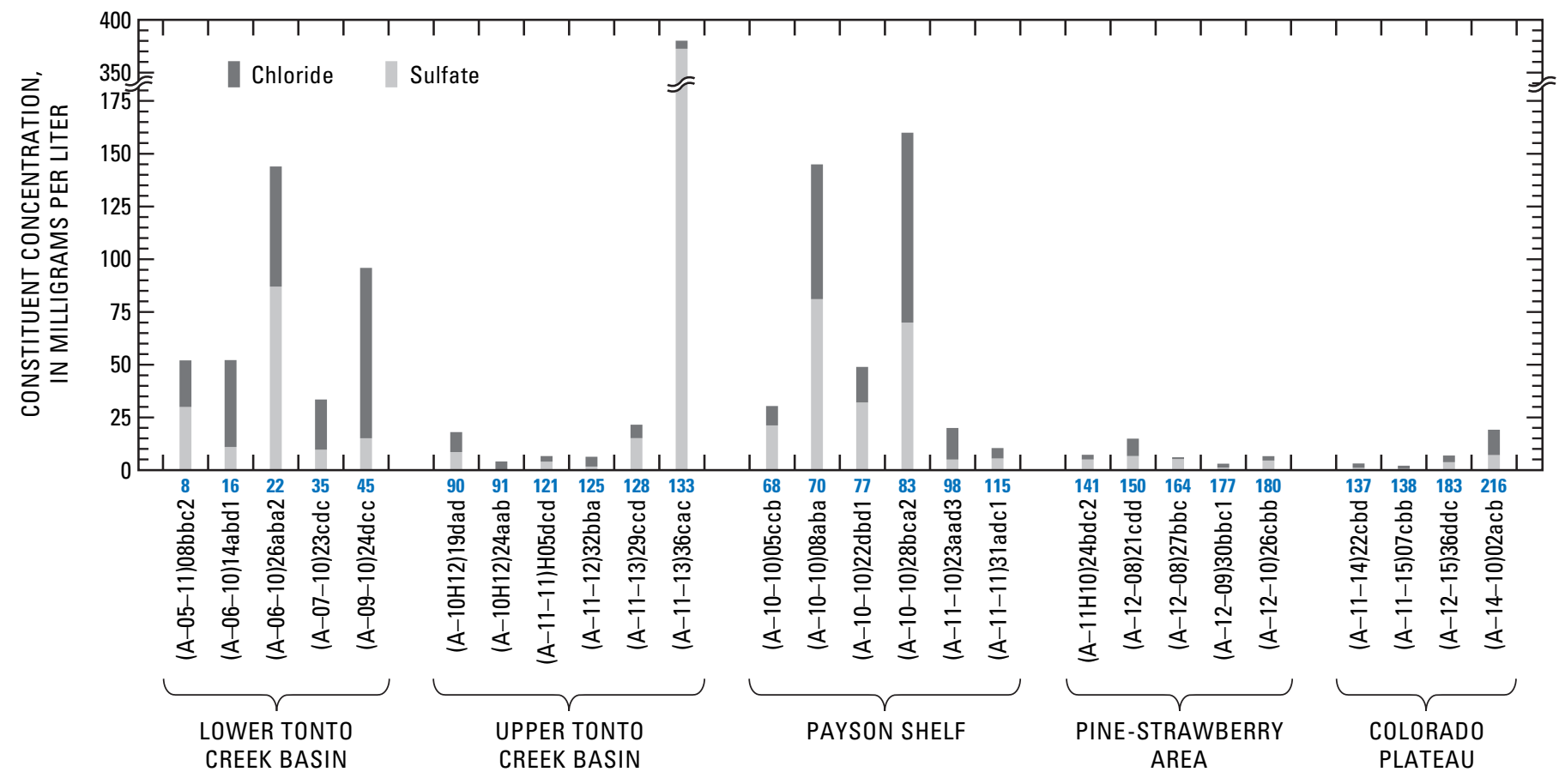

$D$. Concentration of silica

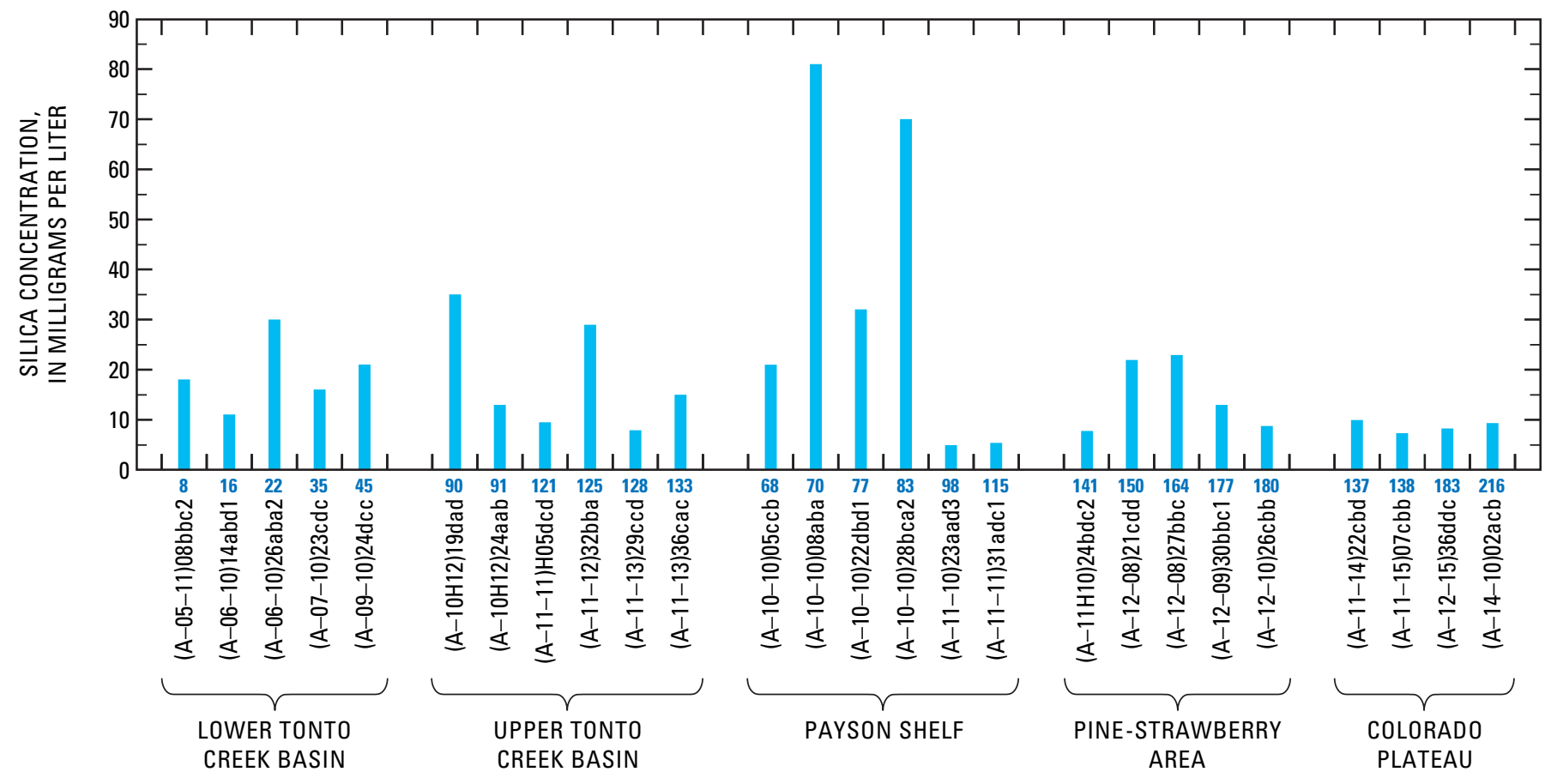

NOTE: See fig. 24 for correspondence of numbers and well names to location and table 8 for chemical composition values.

Repeated locations represent multiple sampling and analyses

Figure 25. Continued. 


\section{Hydrology of the Mogollon Highlands, Central Arizona}

Table 9. Summary statistics of water-chemistry data for Mogollon Highlands streams

[ $\mu \mathrm{S} / \mathrm{cm}$, microsiemens per centimeter; $\mathrm{mg} / \mathrm{L}$, milligrams per liter]

\begin{tabular}{|c|c|c|c|c|c|c|c|c|c|c|}
\hline Statistic & $\begin{array}{c}\text { Specific } \\
\text { conduct- } \\
\text { ance } \\
(\mu \mathrm{S} / \mathrm{cm})\end{array}$ & pH, field & $\begin{array}{c}\text { Water } \\
\text { temper- } \\
\text { ature } \\
\text { (degrees } \\
\text { Celsius) }\end{array}$ & $\begin{array}{c}\text { Oxygen, } \\
\text { dissolved } \\
\text { (mg/L) }\end{array}$ & $\begin{array}{c}\text { Hardness } \\
\text { (mg/L as } \\
\left.\mathrm{CaCO}_{3}\right)\end{array}$ & $\begin{array}{l}\text { Dissolved } \\
\text { solids } \\
\text { (tons per } \\
\text { day) }\end{array}$ & $\begin{array}{c}\text { Calcium, } \\
\text { dissolved } \\
\text { (mg/L) }\end{array}$ & $\begin{array}{l}\text { Magne- } \\
\text { sium, } \\
\text { dissolved } \\
\text { (mg/L) }\end{array}$ & $\begin{array}{l}\text { Sodium, } \\
\text { dissolved } \\
\text { (mg/L) }\end{array}$ & $\begin{array}{l}\text { Potas- } \\
\text { sium, } \\
\text { dissolved } \\
\text { (mg/L) }\end{array}$ \\
\hline \multicolumn{11}{|c|}{ Tonto Creek above Gun Creek (09499000). Samples collected 01-28-1976 to 05-28-1992 } \\
\hline Maximum & 660 & 8.90 & 31.0 & 17.2 & 220 & 620 & 59 & 17 & 52 & 2.6 \\
\hline Mean & 419 & 8.17 & 18.6 & 9.5 & 150 & 58 & 42 & 11 & 29 & 1.8 \\
\hline Median & 424 & 8.20 & 19.5 & 9.2 & 150 & 19 & 42 & 12 & 31 & 1.8 \\
\hline Standard deviation & 127 & .35 & 8.0 & 2.2 & 29 & 110 & 7.6 & 2.7 & 14 & .51 \\
\hline Coefficient of variation & .30 & .04 & .4 & .2 & .19 & 1.8 & .18 & .23 & .49 & .28 \\
\hline
\end{tabular}

West Clear Creek near Camp Verde (09505800). Samples collected 09-15-1967 to 03-24-2000

\begin{tabular}{lccccccccccc}
\hline Maximum & 380 & 8.75 & 27.1 & 11.3 & 200 & 490 & 42 & 24 & 7.5 & 1.9 \\
Minimum & 65 & 5.58 & 5.5 & 7.3 & 35 & 6.5 & 8.6 & 3.3 & 1.1 & .68 \\
Mean & 320 & 8.38 & 15.5 & 9.2 & 150 & 41 & 31 & 18 & 4.9 & 1.2 \\
Median & 353 & 8.55 & 15.1 & 9.3 & 170 & 9.6 & 34 & 21 & 5.6 & 1.2 \\
Standard deviation & 88 & .46 & 5.8 & 1.0 & 53 & 88 & 10 & 6.7 & 1.6 & .24 \\
Coefficient of variation & .28 & .05 & .4 & .1 & .35 & 2.2 & .33 & .37 & .33 & .19 \\
Number of samples & 99 & 99 & 98 & 90 & 65 & 62 & 65 & 65 & 63 & 63 \\
\hline
\end{tabular}

East Verde River near Childs (09507980). Samples collected 12-04-1990 to 05-30-2000

\begin{tabular}{lccccccccccc}
\hline Maximum & 800 & 8.59 & 30.6 & 11.6 & 250 & 250 & 61 & 24 & 94 & 4.9 \\
Minimum & 195 & 7.76 & 6.0 & 5.6 & 87 & .05 & 23 & 7.1 & 4.0 & .74 \\
Mean & 413 & 8.35 & 17.8 & 8.9 & 180 & 23 & 41 & 18 & 20 & 1.9 \\
Median & 402 & 8.40 & 17.0 & 8.8 & 180 & 11 & 40 & 18 & 14 & 1.6 \\
Standard deviation & 104 & .19 & 7.6 & 1.5 & 28 & 44 & 7.3 & 3.2 & 19 & .93 \\
Coefficient of variation & .25 & .02 & .4 & .2 & .16 & 2.0 & .18 & .17 & .94 & .49 \\
Number of samples & 56 & 55 & 56 & 55 & 56 & 56 & 56 & 56 & 56 & 56 \\
\hline
\end{tabular}

Wet Bottom Creek near Childs (09508300). Samples collected 01-29-1968 to 01-29-1996

\begin{tabular}{lcrrrrrrrrrrr}
\hline Maximum & 580 & 12.00 & 32.0 & 12.2 & 240 & 35 & 62 & 20 & 40 & 3.4 \\
Minimum & 17 & 6.00 & .2 & 5.4 & 18 & .02 & 4.8 & 1.1 & 2.5 & .50 \\
Mean & 258 & 7.81 & 16.0 & 8.8 & 94 & 2.5 & 25 & 7.4 & 19 & 1.2 \\
Median & 282 & 7.90 & 15.0 & 8.4 & 100 & .45 & 27 & 7.8 & 20 & 1.2 \\
Standard deviation & 129 & .70 & 7.1 & 1.5 & 47 & 5.6 & 13 & 3.8 & 10 & .44 \\
Coefficient of variation & .50 & .09 & .4 & .2 & .50 & 2.3 & .50 & .51 & .54 & .36 \\
Number of samples & 190 & 183 & 223 & 119 & 176 & 171 & 176 & 176 & 176 & 176
\end{tabular}


Table 9. Summary statistics for water chemistry in Mogollon Highland streams-Continued

\begin{tabular}{|c|c|c|c|c|c|}
\hline Statistic & $\begin{array}{c}\text { Sulfate, dissolved } \\
\text { (mg/L) }\end{array}$ & $\begin{array}{c}\text { Chloride, } \\
\text { dissolved (mg/L) }\end{array}$ & $\begin{array}{l}\text { Fluoride, dissolved } \\
\qquad(\mathrm{mg} / \mathrm{L})\end{array}$ & $\begin{array}{l}\text { Silica, dissolved } \\
\text { (mg/L) }\end{array}$ & $\begin{array}{l}\text { Suspended sediment } \\
(\mathrm{mg} / \mathrm{L})\end{array}$ \\
\hline \multicolumn{6}{|c|}{ Tonto Creek above Gun Creek (09499000). Samples collected 01-28-1976 to 05-28-1992 } \\
\hline Maximum & 21 & 92 & 0.70 & 18 & 2,200 \\
\hline Minimum & 5.9 & 3.2 & .20 & 9.0 & .00 \\
\hline Mean & 14 & 44.6 & .38 & 13 & 99 \\
\hline Standard deviation & 2.8 & 25 & .12 & 2.4 & 430 \\
\hline Coefficient of variation & .19 & .57 & .32 & .19 & 4.3 \\
\hline Number of samples & 56 & 58 & 57 & 58 & 26 \\
\hline
\end{tabular}

West Clear Creek near Camp Verde (09505800). Samples collected 09-15-1967 to 03-24-2000

\begin{tabular}{|c|c|c|c|c|c|}
\hline Maximum & 9.7 & 6.2 & 0.20 & 19 & 2,700 \\
\hline Minimum & 1.0 & .69 & .00 & 9.1 & 1.0 \\
\hline Mean & 2.4 & 3.1 & .11 & 15 & 66 \\
\hline Standard deviation & 1.5 & 1.1 & .03 & 2.0 & 370 \\
\hline Coefficient of variation & .62 & .35 & .29 & .13 & 5.6 \\
\hline
\end{tabular}

East Verde River near Childs (09507980). Samples collected 12-04-1990 to 05-30-2000

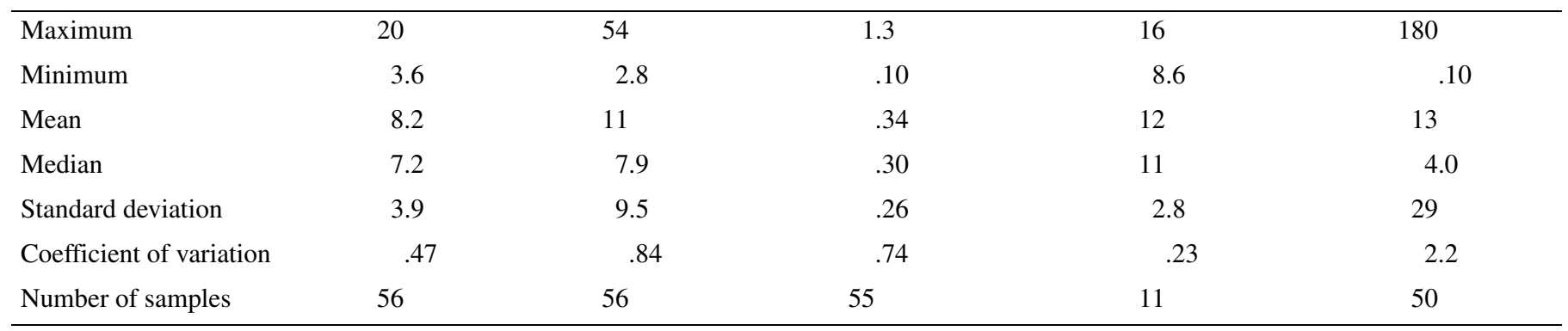

Wet Bottom Creek near Childs (09508300). Samples collected 01-29-1968 to 01-29-1996

\begin{tabular}{|c|c|c|c|c|c|}
\hline Maximum & 28 & 30 & 3.3 & 52 & 110 \\
\hline Minimum & .00 & 1.5 & .00 & 7.9 & .00 \\
\hline Mean & 8.0 & 8.5 & 1.4 & 29 & 4.8 \\
\hline Standard deviation & 3.8 & 4.9 & .74 & 9.2 & 13 \\
\hline Coefficient of variation & .47 & .58 & .52 & .32 & 2.7 \\
\hline
\end{tabular}




\section{Hydrology of the Mogollon Highlands, Central Arizona}

Table 10. Oxygen and hydrogen isotope values for Mogollon Highlands springs

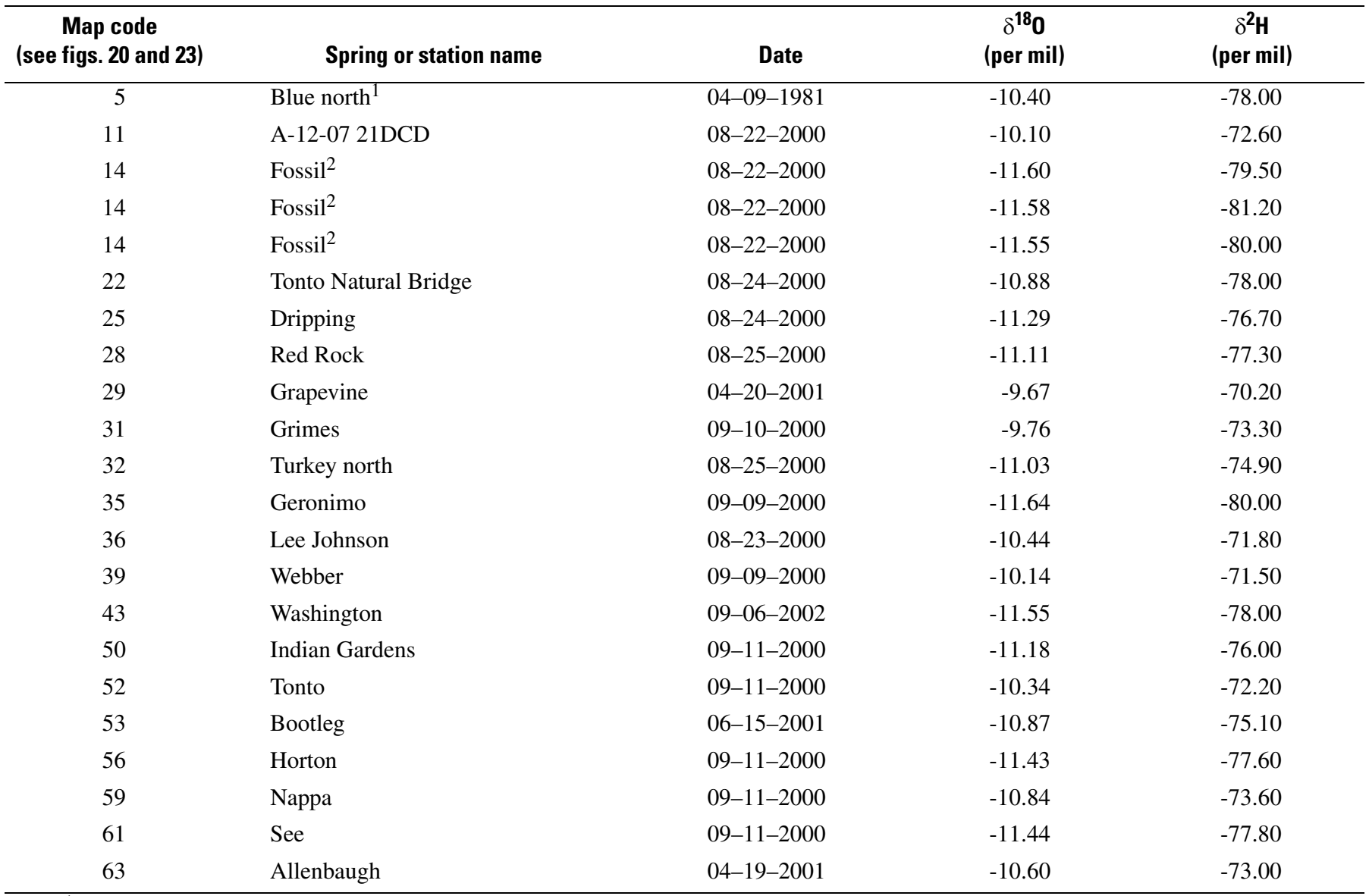

${ }^{1}$ Obtained from U.S. Geological Survey water-quality database. All other samples collected in this study.

${ }^{2}$ Samples collected from three different outlets.

Table 11. Strontium isotope values for spring waters and host rocks

[ $\mu \mathrm{g} / \mathrm{L}$, micrograms per liter; N, normal; NA, not applicable]

\begin{tabular}{|c|c|c|c|c|c|}
\hline $\begin{array}{l}\text { Map code } \\
\text { (see fig. 20) }\end{array}$ & Spring or station name & $\begin{array}{l}\text { Strontium } \\
(\mu \mathrm{g} / \mathrm{L})\end{array}$ & $\begin{array}{l}{ }^{87} \mathrm{Sr} /{ }^{86} \mathrm{Sr} \text { for } \\
\text { spring water }\end{array}$ & $\begin{array}{c}{ }^{87} \mathrm{Sr} /{ }^{86} \mathrm{Sr} \text { for } \\
\text { source rocks } \\
(0.1 \mathrm{~N} \mathrm{HCl} \mathrm{leach)}\end{array}$ & Source rocks \\
\hline NA & NA & NA & NA & 0.71225 & Coconino Sandstone $^{1}$ \\
\hline 25 & Dripping & 160 & 0.70719 & .70894 & Schnebly Hill Formation (siltstone) \\
\hline 31 & Grimes & 1,140 & .70577 & .70539 & Payson granite \\
\hline 61 & See & 115 & .70900 & .70928 & Schnebly Hill Formation (sandstone) \\
\hline 52 & Tonto & 40 & .71076 & .71036 & Schnebly Hill Formation (limestone) \\
\hline 39 & Webber & 100 & .71132 & .71018 & Martin Formation (limestone) \\
\hline 32 & Turkey (north) & 102 & .70724 & .70894 & Supai Formation (siltstone) \\
\hline 22 & Tonto Natural Bridge & 165 & .70912 & .71233 & Tapeats Sandstone \\
\hline
\end{tabular}

${ }^{1}$ None of springs sampled for strontium analysis discharge from Coconino Sandstone, but recharge occurs through these rocks for most springs. 
Of the Colorado Plateau springs with the most dilute waters, (A-12-13H)01BBD has a significantly higher silica concentration than (A-12-12)11BAB and (A-12-10)01BDA (fig. 22D), suggesting a longer groundwater residence time. This is consistent with the northerly ground-water flow in the vicinity of this spring based on the potentiometric-surface map by Hart and others (2002) and the flow gradient in this area being lower than in the vicinity of the Mogollon Rim. Colorado Plateau springs in the West Clear Creek drainage_-Pivot Rock, Bear, and Buckhorn Springs - have higher solute and silica concentrations than those mentioned above (fig. 22A, $D$ ). These springs discharge in an area of basaltic rocks, the glassy matrix of which is much more soluble than sandstone components. Spring (A-12-11)12AAC (table 7, no. 48 and fig. 20), though discharging on the Colorado Plateau above the Mogollon Rim, generally has higher solute concentrations than the most dilute springs (fig. 22A). Its lower calcium-magnesium ratio (fig. 22B) and much higher bicarbonate concentration (table 7) and calcium-sodium ratio suggest contact with the Kaibab Formation during recharge, and its low sodium and silica concentrations suggest a residence time on the order of that of spring (A-12-12)11BAB (fig. 22B, D).

As noted earlier, the chemistries of all springs below the Mogollon Rim derive from the rock and water chemistries of those geologic units on the Colorado Plateau. Their calcium-sodium ratios are compatible with the expected reaction of waters with arenaceous rocks, such as the Coconino Sandstone and the upper sandstone unit of the Schnebly Hill Formation. Variations from this initial signature result from flow through other rock types. Large calcium-sodium ratios and high silica concentrations of springs (A-12-07)21DCD and (A-12-07)22C UNSURV (table 7, nos. 11 and 12 and figs. 20 and 22B, $D$ ) in Fossil Creek Canyon reflect flow through and discharge from the basaltic rocks that cap Hardscrabble Mesa. In addition, the aqueous strontiumisotope ratio $\left({ }^{87} \mathrm{Sr} /{ }^{86} \mathrm{Sr}\right)$ of spring

(A-12-07)21DCD is in close agreement with that of a basalt sample from this locale collected during this study (table 11), confirming the basaltic signature. The principal direction of regional ground-water flow in the vicinity of these two springs is to the southwest; however, springs (A-12-07)21D UNSURV and (A-12-07)22C UNSURV are on north-facing slopes below Hardscrabble Mesa (fig. 1) and are supplied by ground-water flow to the northwest. These springs, therefore, almost certainly are not connected to the regional flow system and only drain the Hardscrabble Mesa basalts. The $\delta^{2} \mathrm{H}$ and $\delta^{18} \mathrm{O}$ data for spring
(A-12-07)21DCD indicate that the water has a significant component of precipitation that reflect conditions warmer than those which controlled the isotopic signature of paleorecharge in Fossil Springs (fig. 23).

The $\delta^{2} \mathrm{H}$ and $\delta^{18} \mathrm{O}$ data for Fossil Springs, from samples collected at three different spring outlets, are at the light end of the data range, indicating colder recharge conditions than present-day conditions (table 10, no. 14 and fig. 23). The spring chemistry is indicative of recharge through the Coconino Sandstone and flow through limestone because it is a calcium magnesium bicarbonate water that has, except for silica and some minor solutes, the highest solute concentrations of all the springs (fig. $22 A-D$ ). The spring discharges essentially at the contact of the Redwall Limestone and the overlying Naco Formation, which have strontium isotope ratios of 0.70865 and 0.70905 , respectively (table 11). The corresponding value for Fossil Springs water is 0.70899 . This close correspondence suggests the strontium-isotope imprint of the Redwall and Naco rocks has been superimposed on Fossil Springs water over the initial strontium-isotope signatures the water would have obtained from reaction with feldspar grains and secondary calcite cement in the Coconino Sandstone that has a ${ }^{87} \mathrm{Sr} /{ }^{86} \mathrm{Sr}$ value of 0.71225 .

Tonto Natural Bridge Spring, southeast of Fossil Creek, has similar chemical characteristics as Fossil Springs, but is slightly more dilute (table 7, no. 22 and figs. 20 and 22A). A relatively high silica concentration, however, reflects the influence of basaltic rocks that cap the Paleozoic rocks that flank the spring (fig. 22D). The $\delta^{2} \mathrm{H}$ and $\delta^{18} \mathrm{O}$ values indicate a small degree of enrichment over the waters of Fossil Springs (table 10, no. 14 and fig. 23). Big Spring and Webber Spring are both in the East Verde River drainage basin and they have similar concentrations of dissolved solids (table 7 , nos. 37 and 39 and figs. 20 and 22A) and are more dilute than Tonto Natural Bridge Spring. Isotope values for Webber Spring are at the heavier end of the data range, suggesting warmer recharge conditions than for Tonto Natural Bridge or Fossil Springs (fig. 23). On the other hand, both Geronimo and Washington Springs, which are in the headwaters of the East Verde River drainage, have $\delta^{2} \mathrm{H}$ and $\delta^{18} \mathrm{O}$ values near the light end of the data range (table 10, nos. 35 and 43 and figs. 20 and 23), and Turkey Spring in the headwaters of Webber Creek, a tributary of the East Verde River, has $\delta^{2} \mathrm{H}$ and $\delta^{18} \mathrm{O}$ values in the middle of the range (table 10, no. 32 and figs. 20 and 23).

Dripping Springs discharges on the western side of Milk Ranch Point, a south-jutting promontory of the Mogollon Rim (figs. 1 and 20). This spring differs from 
others at or adjacent to the Mogollon Rim in that its silica concentration is higher (table 7, no. 25 and fig. 22D), suggesting that it is influenced by the volcanic rocks that cap the promontory. Its $\delta^{2} \mathrm{H}$ and $\delta^{18} \mathrm{O}$ values are similar to those of other springs discharging from the face of the Mogollon Rim and suggest a slightly larger component of warmer recharge, which could be expected with recharge of local, recent cold-season precipitation through the capping volcanic rocks (fig. 23). This seems more likely than enrichment of a Colorado Plateau source, as the spring discharges at a low rate from within the Schnebly Hill Formation. Its stratigraphic position and relatively high bicarbonate and calcium concentrations, together with its ${ }^{87} \mathrm{Sr} /{ }^{86} \mathrm{Sr}$ value, suggest that most of the dissolved strontium contribution is due to basalt-water interaction, and that the spring discharge does not include a significant component of water recharged through the Colorado Plateau (table 11).

Springs near or below the base of the Mogollon Rim for which chemical analyses are available-Tonto Natural Bridge, Webber, (A-11H10)24BCA1, Indian Gardens, Bear Flat, and R-C Springs-tend to have higher calcium, magnesium, and sodium concentrations than springs discharging from the rim face because of longer travel and water-rock interaction times (table 7 , nos. 22, 39, 42, 50, 54, and 58 and fig. 22B). The ranges in concentrations of individual solutes also are a function of the rock types traversed by the individual flow paths.

Indian Gardens and R-C Springs and Spring (A-11H10)24BCA1 are nearest the face of the Mogollon Rim within this group and about equidistant from it (table 7, nos. 50, 58, 42). On the basis of the most recent analytical data, the chemistry of Indian Gardens resembles that of Spring (A-11H10)24BCA1 in relative solute concentrations (table 7 and fig. 22B), but Indian Gardens has the highest specific conductance value in the group of seven, and individual concentrations are about double those of Spring (A-11H10)24BCA1 (table 7, no. 42 and fig. 22A). Both issue from lower Paleozoic rocks, and their chemistries are dominated by interaction with limestone (calcium magnesium bicarbonate) waters. The Indian Gardens water, however, is chemically more evolved, suggesting a longer flow path and residence time (table 7, no. 50 and fig. 22B). Bear Flat Spring chemically resembles R-C Spring in its relative chemical abundance (table 7, nos. 54 and 58; fig. 22B).

The isotopic signature of Grimes and Grapevine Springs, discharging from mafic granitic rocks east of Payson (table 10, nos. 29 and 31 and figs. 20 and 23), show enrichment indicative of warm-water recharge or evaporation. The springs are in fractured rocks in an area of rugged topography but low relief and are likely recharged by recent warm-water precipitation falling on relatively low altitudes. They are isotopically closest to Lee Johnson Spring on the southern edge of the Colorado Plateau (table 10, no. 36 and figs. 20 and 23), another spring that appears to discharge from a shallow groundwater system and is probably recharged locally as well as spring (A-12-07)21DCD that is discussed above (table 10, no. 11). Grimes and Grapevine are also similar isotopically to Webber Spring and Tonto Spring, both of which appear to indicate mixing of more recent warmer recharge waters with the older waters of the $\mathrm{C}$ aquifer, perhaps as a result of rapid infiltration through a fractured rock system.

\section{Chemistry of Well Waters}

The chemical composition of Mogollon Highlands well waters show little spatial correlation, and generalizations of constituent concentrations and geographic location are difficult to make. For the most part, well waters are dilute and have the most consistently low values of specific conductance in the Pine-Strawberry area and the lower Tonto Creek Basin (table 8 and figs. 24 and 25A); however, in the case of PineStrawberry, well chemistry data are few. Specific conductance values generally are less than $600 \mu \mathrm{s} / \mathrm{cm}$ in well waters throughout the study area, but values of more than $1,000 \mu \mathrm{s} / \mathrm{cm}$ are found in water in wells scattered mainly across the Payson shelf and in the carbonate rocks of the upper Tonto Creek Basin. The highest silica concentrations tend to be in the waters of wells along the Payson shelf, reflecting the influence of igneous and metamorphic rocks in which the wells are drilled. The high variability in ionic constituents (figs. 25B, $C$ ) reflect the complexity of flow paths throughout the study area.

\section{Chemistry of Surface Waters}

Water-chemistry samples have been collected from four streams in the Mogollon Highlands during varying time periods (table 9). Because samples usually are collected during base-flow conditions, the chemical make up of the waters may reflect ground-water chemistry to some extent. The samples found to be the most dilute were collected in the waters of West Clear Creek, which primarily drains the Coconino Sandstone of the $\mathrm{C}$ aquifer, and Wet Bottom Creek, which drains the metamorphic and igneous rocks of the Mazatzal Mountains. Maximum and average values of specific 
conductance are lowest for the samples from these two streams; however, the relative constituent concentrations do not vary significantly from those of the samples from the waters of East Verde River and Tonto Creek, which drain the carbonate rocks of the limestone aquifer before flowing into the igneous and metamorphic terranes of their lower reaches. Surface-water chemistry seems to reflect the generally low degree of chemical evolution in Mogollon Highlands waters.

\section{Hydrogeologic Framework and Conceptual Model}

Data on water levels, spring discharge, and spring altitudes are primarily for the upper part of the stream basins that drain the study area; long-term streamflow records are all for locations near the southern and eastern boundaries of the study area. A reasonable approximation of the ground-water system and its geologic controls can, therefore, be constructed for the upper basins. Between the base of the Mogollon Rim and the drainage outlets, however, few data are available, except in the Payson granitic aquifer and in the shallow alluvial aquifer of lower Tonto Creek. Delineation of ground-water flow paths in much of the study area is problematic because of the presence of multiple waterbearing zones and because many published water levels in wells are based upon anecdotal reports as much as 50 years old. Consequently, attempts to define such flow paths, especially in deeper water-bearing zones, must be considered tentative. Some characteristics of the groundwater system can be derived from analysis of surfacewater records, particularly the relative contribution of base flow and runoff to the total water budget and the relative unit-values of water yield. Nonetheless, chemical characteristics, distribution and flow characteristics of springs and wells, and their relation to geologic and topographic features suggests that the $\mathrm{C}$ aquifer is the origin of virtually all the regional ground-water flow within the study area, including that which discharges from the underlying limestone aquifer (figs. 26 and 27).

\section{Recharge Zone}

Feth and Hem (1963) provided a descriptive view of recharge processes along the Mogollon Rim. Water from precipitation and snowmelt percolates through the permeable volcanic, limestone, or sandstone units to the rocks below. The Mogollon Rim within the study area is capped primarily by volcanic rocks in the west and by as much as $1,200 \mathrm{ft}$ of Coconino Sandstone in the east. The Coconino Sandstone generally underlies the volcanic rocks as well. The ground-water system of the study area originates primarily from a narrow recharge zone of about $225 \mathrm{mi}^{2}$ along the crest of the Mogollon Rim. On the basis of PRISM (Parameter-elevation Regressions on Independent Slopes Model) data, an average of $31.2 \mathrm{in} / \mathrm{yr}$ of precipitation, about 375,000 acre$\mathrm{ft}$, falls on the this area between the top edge of the Mogollon Rim and the $\mathrm{C}$ aquifer ground-water divide, from Cibecue Creek on the east and West Clear Creek on the west (figs. 5 and 26). Beneath that recharge zone, Hart and others (2002) describe a mound of ground water, the top of which is within the Coconino Sandstone at an altitude of $6,800 \mathrm{ft}$, about $700 \mathrm{ft}$ below the land surface (fig. 26). The spatial distribution of high-discharge springs in regional carbonate aquifers and chemical characteristics of waters from those springs point to a source in the Coconino Sandstone. Little evidence exists of significant discharge from the Coconino Sandstone, except for that issuing from Buckhorn Spring and in base flow of West Clear Creek in the northwestern part of the study area (fig. 15, no. 15). Wells on the Colorado Plateau north of the Mogollon Rim, however, generally are producing from the Coconino Sandstone, indicating that the highest potentiometric surface is within the formation. The Coconino Sandstone forms a sheer cliff face along the top of the Mogollon Rim, but seeps and springs are not abundant. The highest altitude springs that produce significant discharge are those flowing from the Fort Apache Member of the Schnebly Hill Formation in the headwaters of Tonto and Canyon Creeks.

Other major springs in the study area discharge from the limestone aquifer that includes all the Paleozoic sedimentary units from the Naco Formation to the basement rocks, which can be either Tapeats Sandstone or Proterozoic crystalline rocks (fig. 15). Chemical evidence, distribution of springs, and known flow paths suggest that the limestone aquifer is recharged primarily from vertical flow originating in the overlying $\mathrm{C}$ aquifer. The maximum possible extent of the limestone aquifer is controlled by the boundaries of the carbonate rocks as suggested in isopach maps that show the Redwall Limestone pinching out in the northeastern corner of the study area (McKee and Gutschick,1969) and the Martin Formation pinching out to the northeast beneath the Little Colorado River (Teichert, 1965). 


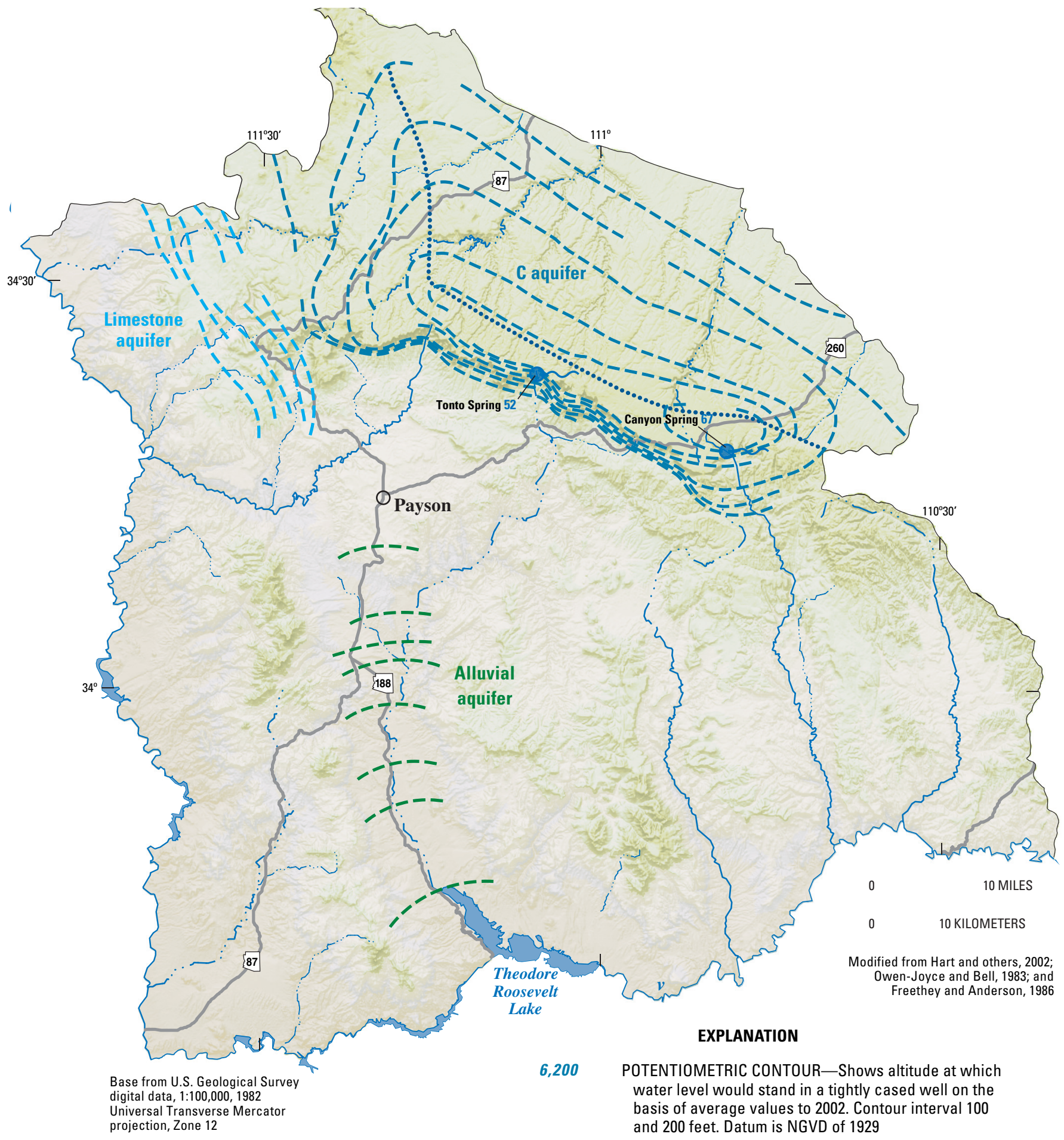

NOTE: Tail on symbol is not intended to indicate direction of discharge

Figure 26. Potentiometric surfaces of the $C$ aquifer, limestone aquifer, and alluvial aquifer in the lower Tonto Creek Basin, Mogollon Highlands, Arizona. 


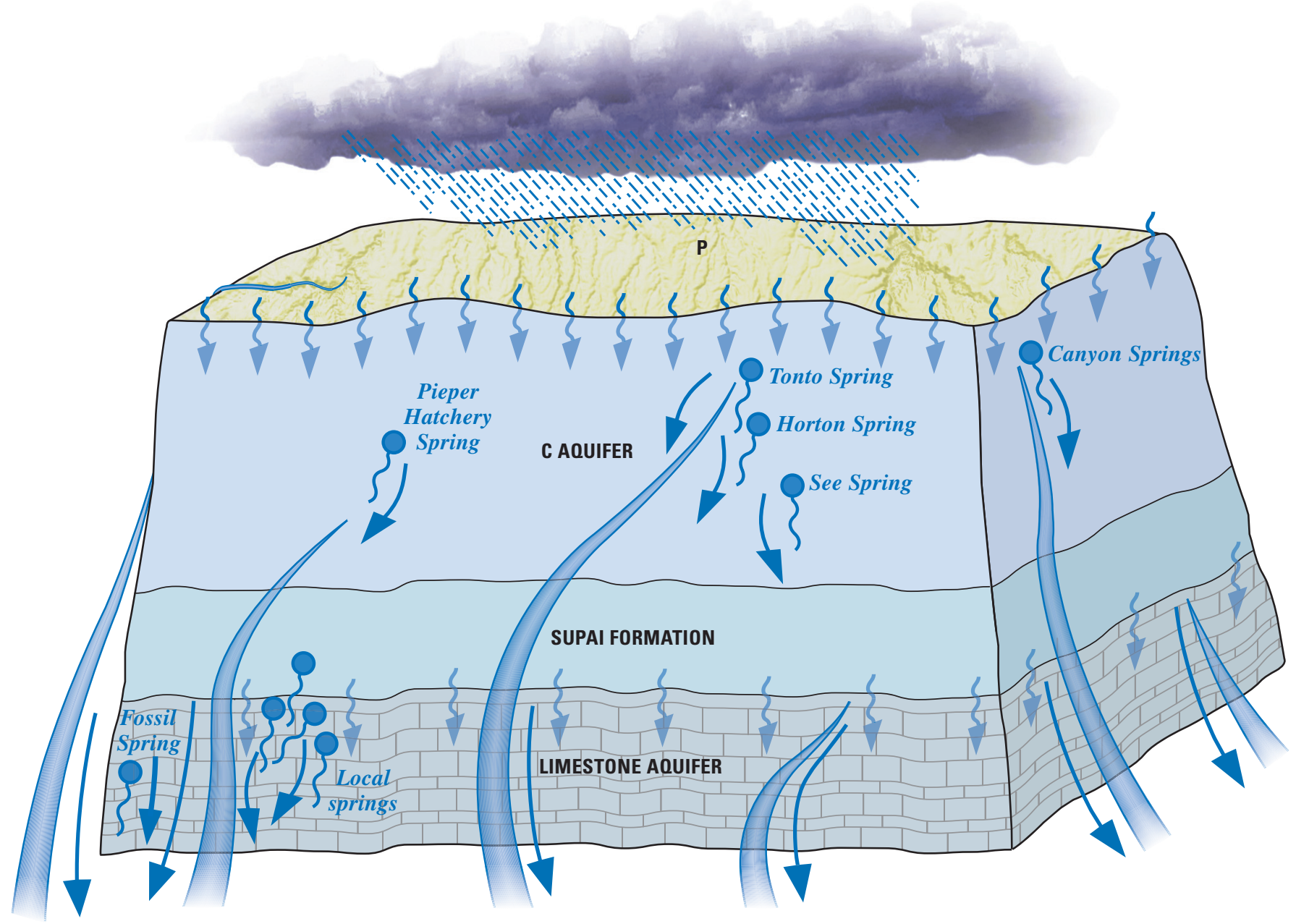

Figure 27. Schematic diagram of the ground-water system in the Mogollon Highlands, central Arizona.

No attempt has been made to delineate a ground-water divide for the limestone aquifer, although it presumably trends roughly parallel to the ground-water divide of the $\mathrm{C}$ aquifer on the Colorado Plateau (fig. 26). Additional recharge of the limestone aquifer can occur by infiltration of streamflow originating on the upper slopes of the Mogollon Rim as a result of runoff or discharge from the $\mathrm{C}$ aquifer springs, or from precipitation on the face of the Mogollon Rim and the tablelands near the base of the rim where limestone rocks are exposed. For most of the study area, recharge from precipitation or runoff is not likely to be a major component of the total water budget for the limestone aquifer because the Mogollon Rim face is quite steep with slopes of 10 to nearly 100 percent, and the tablelands are primarily a discharge area where much of the limestone aquifer is drained. For recharge to take place below the top of the Mogollon Rim, rapid vertical flow through large, open-joint or cavern systems would have to occur if the water were to reach the aquifer upstream from the principal discharge points. Some mixing of recent recharge with spring flow is suggested by the hydrogen and oxygen isotopic signature of Tonto Natural Bridge and Webber Springs (table 10, nos. 22 and 39 and fig. 23).

One area where local recharge of the limestone aquifer might be significant is along the eastern edge of the study area near Cibecue Creek where a southeasttrending plateau is capped by middle Paleozoic rocks. The more subdued slopes of this area and the presence of major structures along the western boundary of the plateau could facilitate local recharge (figs. 1 and 4). Numerous springs appear along the canyon walls flanking Cibecue Creek; however, they have not been inventoried by any State or Federal agency, and there are no data available on their flow characteristics that would help evaluate the likelihood of local recharge in this area. 


\section{Hydrology of the Mogollon Highlands, Central Arizona}

The study area includes several local aquifers that have little or no hydraulic connection to the regional aquifers and, therefore, must be recharged locally. These aquifers include the water-bearing zones of the Schnebly Hill Formation in the Strawberry area and the Supai Formation in the Pine area and in the western headwaters of the East Verde River. Several lines of evidence suggest that these aquifers share a common, restricted recharge zone on the crest of the Mogollon Rim. Such evidence includes, the absence of highdischarge carbonate springs within the Schnebly Hill Formation, the similarity in $\delta^{2} \mathrm{H}$ and $\delta^{18} \mathrm{O}$ values among low-discharge springs-Dripping, Red Rock, and Turkey Springs (table 10, nos. 25, 28 and 32 and fig. 23)—emanating from siltstones and very fine sandstones below Milk Ranch Point (figs. 1 and 20), and the high silica concentrations of Dripping Springs waters (table 10, no. 25 and fig. 22D) indicative of flow through basaltic rocks that cap Milk Ranch Point.

Other local recharge zones within the study area include the basalt-covered mesas of Fossil Creek Canyon, the Payson granite and related granitic rocks that form the Payson Shelf, and the upper slopes of the Mazatzal Mountains and Sierra Ancha. Virtually all the water-bearing zones in the Payson granite are locally recharged by percolation of meteoric waters through fractures and weathered rock. Ploughe (2001) suggests, however, that deeper water-bearing zones may occur in fractures that capture ground-water flow from the Mogollon Rim.

Within the Proterozoic rocks of the Mazatzal Mountains and Sierra Ancha, the occurrence of some low-discharge springs and base flow in the streams draining those mountains, especially Cherry Creek, suggest that these areas are at least minor recharge zones.

\section{Upper Discharge Zone}

The sedimentary rocks that compose the $\mathrm{C}$ aquifer are drained by at least 36 springs along the face of the Mogollon Rim. The most important discharge points are West Clear Creek, including Buckhorn Spring, on the western edge of the study area, and the high-volume springs in upper Tonto and Canyon Creeks to the east (figs. 15 and 27). Except for Buckhorn Spring, which is on the Colorado Plateau, all the springs having reported discharges of more than $100 \mathrm{gal} / \mathrm{min}$ discharge from carbonate rocks (fig. 15 and table 4). From Pieper Hatchery Spring in the uppermost headwaters of East Verde River east to Tonto and Canyon Creeks, highdischarge springs flow from the Schnebly Hill
Formation, mainly from the Fort Apache Member. Spring altitudes in this area range from about 6,200 to $6,800 \mathrm{ft}$, which is about 800 to $1,300 \mathrm{ft}$ below the crest of the Mogollon Rim.

The absence of significant spring discharge above the Fort Apache Member indicates that the movement of water within the highly fractured Coconino Sandstone and in the Schnebly Hill Formation is primarily vertical until it reaches the limestone of the Fort Apache Member (fig. 27). Chemical data for Horton and Tonto Springs in the headwaters of Tonto Creek and for See Spring in the headwaters of Christopher Creek, show similar calcium-magnesium ratios that are indicative of water that has flowed through clastic rocks (table 7, nos. 56, 52, and 61 and fig. 22B). Low silica concentrations in these waters suggest little chemical evolution, an indication of rapid ground-water flow from the recharge site to the springs.

Flow characteristics vary from one spring to another. Long-term records of flow from Tonto Spring show little fluctuation in base flow over a 20 -year period (fig. 16A). Stability of flow in Tonto Spring results from its location about $300 \mathrm{ft}$ below the crest of the groundwater mound (fig. 26). In the headwaters of Christopher Creek, See and Nappa Springs appear to be considerably less stable, but few discharge measurements have been published (table 4, nos. 61 and 59). Both springs discharge from bouldery alluvium, so it is not clear whether they issue originally from the Fort Apache Member or from other rocks in the Schnebly Hill or Supai Formations. Fluctuation of discharge most likely reflects their location near the top of the ground-water mound (fig. 26) where they are affected by changes in its altitude.

Discharge at Canyon Springs was stable until the mid 1990s when its average discharge declined from about 2,500 to 1,500 gal/min (fig. 16A). Canyon Springs are situated at an altitude of $6,800 \mathrm{ft}$, which is also near the top of the ground-water mound (fig. 15, no. 67). Consequently, the springs are susceptible to the effects of short-term climatic fluctuations that result in changes to the water table at the top of the $\mathrm{C}$ aquifer. The reduction in discharge from Canyon Springs might reflect drought conditions of recent years. Although there are a few wells on the Colorado Plateau above the spring outlets, there has been no recent large increase in well development that would be likely to produce such an abrupt change in spring discharge by a lowering of the regional groundwater table. 
In the East Verde River drainage, Pieper Hatchery Spring discharges from the Fort Apache Member of the Schnebly Hill Formation (table 4, no. 45 and fig. 15). The only published discharge is an estimated value of $125 \mathrm{gal} / \mathrm{min}$. Discharges from other springs in the headwaters of the East Verde River typically are less than $10 \mathrm{gal} / \mathrm{min}$. The paucity of flow from springs discharging from the sand and siltstones of the Supai Formation parallels the generally poor productivity of wells in that unit in the Pine area (Kaczmarek, 2003). West of Pieper Hatchery Spring there is little or no discharge directly from the $\mathrm{C}$ aquifer along the face of the Mogollon Rim. Indeed, the only major discharge point from the $\mathrm{C}$ aquifer in the western part of the study area appears to be within the persistent base flow of West Clear Creek (table 3), part of which is supplied by discharge from Buckhorn Spring. The absence of significant discharge from the Mogollon Rim face west of the East Verde River implies some structural control that blocks lateral ground-water flow. Such structural control could be a feature that diverts flow vertically into the limestone aquifer.

Except for West Clear Creek, base flow in excess of spring flow in the upper reaches of streams draining the face of the Mogollon Rim does not seem to be a significant source of discharge from the $\mathrm{C}$ aquifer. Most flow in the upper channel reaches in excess of spring flow is almost certainly runoff rather than groundwater discharge.

\section{Lower Discharge Zone}

The lower discharge zone is that area on the lower slopes of the Mogollon Rim face and the tablelands formed by the Naco Formation at the base of the Supai Formation, and the Redwall Limestone, Martin Formation, and Tapeats Sandstone, where present. The underlying Proterozoic rocks are the base of the ground-water flow system, but deep fractures may permit flow into those rocks. With a few exceptions, spring discharge is highly variable from the limestone aquifer of this zone. Heterogeneities in geologic structure, lithology, or both result in variable travel lengths, residence times, flow stability, flow volume, and chemical composition of spring waters. The dilute nature of spring waters draining the limestone aquifer indicates such waters are little evolved and probably share a common source.

The main discharge areas are Fossil Springs, which account for about 60 percent of recorded spring flow in the study area, and Cibecue Creek, where base flow accounts for about 50 percent of total annual streamflow, suggesting a strong ground-water component of streamflow (figs. 13 and 27). Cibecue Creek also flows for most of its length through a canyon, cut into Paleozoic rocks, where numerous springs discharge from the cliffs above the stream. Between Fossil and Cibecue Creeks, most discharge from the limestone aquifer is at springs in the East Verde River and Tonto Creek Basins. All springs with discharges greater than $100 \mathrm{gal} / \mathrm{min}$ flow from carbonate rocks except Tonto Natural Bridge and R-C Springs, which discharge just below the base of carbonate lower Paleozoic rocks.

Fossil Springs discharges from the base of the Naco Formation or the top of the Redwall Limestone (table 4, no. 14). Various measurements during the past 50 years indicate that these springs maintain a flow of about 20,000 gal $/ \mathrm{min}$ that has varied little (table 4 and fig. 16C). The volume and stability of spring flow, as well as the depleted $\delta^{2} \mathrm{H}$ and $\delta^{18} \mathrm{O}$ values, indicate that Fossil Springs has a large contributing area and is connected with the limestone aquifer by large, open structures. The precise location of this connection can only be surmised. It is bound by ground-water divides to the northwest where flow is toward West Clear Creek and to the southeast where flow is toward Pine Creek. Gila County drilled exploratory well (A-12-08)29AAA2 (table 6, no. 166) in the Strawberry area in 2000. The water level in the well, 1,380 ft below land surface, may indicate the potentiometric surface of the limestone aquifer (Corkhill, 2000). Water in the well stands at an altitude of 4,376 ft. The well is about 4 mi east of Fossil Springs, which has an altitude of about 4,290 ft. If those two points are on a flow path at the potentiometric surface of the limestone aquifer, the gradient of the water table is less than 0.5 percent.

No long-term records are available for spring discharge in the East Verde River drainage, but scattered measurements made during the past 50 years indicate that discharge is highly variable in some of the springs. A 2-year record of flow in Pine Creek below Tonto Natural Bridge Spring, however, shows little change in base flow, most of which is supplied by the spring (fig.16B; Robert Sejkora, water program manager, Arizona State Parks, oral commun., 2003). Feth and Hem (1963) suggest that the variability of flow in springs of the East Verde River and its tributaries indicates that the springs are draining an area of low storage. High variability would also indicate the possibility of local recharge resulting in a rapid response of springs to climatic fluctuations. All the springs cited by Feth and Hem (1963), The Grotto, Big Spring, and Cold Spring, were measured in May and July 1952, and Cold Spring 
was measured again in November 1952 (table 4 and figure 15 , nos. 38, 37, and 44). The wide range of discharges recorded in that brief period strongly suggests that the spring discharge is affected by variations in local recharge. With the exception of Pieper Hatchery Spring, all high-discharge carbonate springs in the East Verde River drainage flow from lower Paleozoic rocks, and of those, only Cold Spring discharges on the upthrown side of the Diamond Rim Fault (fig. 15, nos. 45 and 44). The presence of relatively high-discharge springs in Webber Creek and along the East Verde River below the Diamond Rim Fault suggests that faulting is influencing ground-water discharge in this area. Uplift of the lower Paleozoic rocks north of the fault increased the subaerial exposure of lower Paleozoic carbonate rocks, enabling drainage of a thicker section of the Colorado Plateau sediments into the graben below the fault (fig. 15). Another fault to the south, running subparallel to the Diamond Rim Fault, apparently impedes ground-water flow, producing a local bulge in the potentiometric surface between the two faults and causing spring discharge in Webber Creek and along the East Verde River. Tonto Natural Bridge Spring on Pine Creek is situated within the same graben to the northwest, however, it appears to have more stable discharges than the nearby springs. Also, its isotopic signature is more similar to that of Fossil Springs, showing relatively cold recharge conditions, than that of Webber Springs that showed warmer recharge conditions.

Within the Tonto Creek Basin, springs issuing from the limestone aquifer have relatively lower discharge and greater variability in flow than Tonto and Horton Springs in the upper reaches, which account for more flow than all other springs in the basin combined (table 4, nos. 52 and 56). Nonetheless, chemical characteristics of all springs in the Tonto Creek Basin for which data are available show that spring waters are more similar than different, indicating their common origin (table 7 and fig. 22A-D). Indian Gardens Spring has higher specificconductance values and higher concentrations of chemical constituents than neighboring springs, which reflects the local variation in hydrogeologic properties that affects ground-water flow in the limestone aquifer.

Tonto Natural Bridge Spring on Pine Creek has isotopic and specific-conductance values similar to those of Fossil Springs (figs. 22 and 23). Furthermore, flow from both springs is apparently stable, although the period of time during which flow in Tonto Natural Bridge Spring has been measured is considerably less than that for Fossil Springs (fig. 16B,C). This suggests that the contributing area for Tonto Natural Bridge
Spring is large enough to assure a constant supply of water, presumably from the same aquifer as that which supplies Fossil Springs. The slightly greater enrichment of $\delta^{2} \mathrm{H}$ and $\delta^{18} \mathrm{O}$ values, the chemical evidence of flow through basaltic rocks, and the much lower discharge indicate that the Tonto Natural Bridge Spring is not as well connected to the limestone aquifer and that some local recharge is contributing to the flow. In Pine, a well that was completed in November 2002 hit water at a depth of $894 \mathrm{ft}$ below land surface (altitude of 4,608 ft) in the Redwall Limestone (Michael Ploughe, hydrologist, Arizona Hydrologic Source, oral commun., 2003). The well is within the Pine Creek watershed, but whether it is on the Pine Creek or Fossil Creek side of the groundwater divide for the limestone aquifer is uncertain.

Although the springs in the Diamond Rim Fault area are no doubt connected to the limestone aquifer and their waters share a common origin with those in Tonto Natural Bridge and Fossil Springs, they apparently are not as tightly connected to the limestone aquifer. A greater amount of mixing of younger meteoric waters falling on local recharge zones seems to take place along the flow paths leading to the Diamond Rim Fault springs as evidenced by the oxygen isotope signature of Webber Spring waters (fig. 23, no. 39).

\section{Local Water-Bearing Zones on the Mogollon Rim}

On the upper slopes of the Mogollon Rim area, the highest well density is in the Pine and Strawberry areas where ground-water flow in the shallow, local aquifers follows topography, flowing west toward the Verde River in the Strawberry area and south along Pine Creek in the Pine area (table 6 and figs.14 and 18). In Strawberry, the water-level altitude as reported in wells declines from about 5,820 to 5,600 ft over a distance of about $2.3 \mathrm{mi}$. Depth to water generally is less than $100 \mathrm{ft}$. In Pine, the water-level altitude in wells declines from about 5,640 to 5,440 ft over a distance of about $1.8 \mathrm{mi}$ (table 6 and fig. 18). According to Kaczmarek (2003), wells in Strawberry generally are more productive and less prone to effects of drought than wells in Pine. He suggests this is because of the different hydrologic properties of the Schnebly Hill Formation, in which most of the wells in Strawberry are drilled, and the Supai Formation, in which the wells of Pine are drilled, the former having greater primary permeability and storage than do the tight siltstones and very fine sandstones of the latter. In both places, well productivity is dependent on the proximity, density, and 
transmissivity of fractures, but in Pine, the absence of significant storage retards the recovery of wells after drawdown. The shallow aquifers are poorly connected to the regional aquifer system and likely dependent on local recharge over a contributing area of limited extent.

Wells are scattered throughout the tablelands from the East Verde River east to Colcord Canyon (figs. 1, 14, and 18). Most wells are completed in the Redwall Limestone or in the Martin Formation. Those clustered along the East Verde River are little more than $10 \mathrm{ft}$ deep and probably are in alluvium (figs. 1 and 18). To the east near Tonto Village and Kohls Ranch, wells likely are completed in the limestone aquifer and water levels typically are 100 to $200 \mathrm{ft}$ below land surface. Waterlevel altitudes in wells cluster around 5,600 ft, which is similar to the range of altitudes for springs in the area that discharge at surface altitudes from 5,640 to $5,350 \mathrm{ft}$, suggesting that springs are issuing from the same aquifer as the wells. The only well discharge record for the area shows a discharge of $50 \mathrm{gal} / \mathrm{min}$. The wide range of spring discharge in the area, from 4 to $800 \mathrm{gal} / \mathrm{min}$, illustrates the variability of ground-water flow in the tablelands that is a function of geologic structure and climatic fluctuations that affect local recharge.

\section{Local Water-Bearing Zones Below the Mogollon Rim}

Records for major streams that flow out of the Mogollon Rim indicate that base-flow discharge increases downstream under most conditions although that flow may not continue without loss all the way to the mouth of the stream. Except for the Payson Shelf (fig. 1), hydrogeologic characteristics of the predominantly Proterozoic rocks across which the East Verde River, Tonto Creek, Cherry Creek, and Canyon Creek flow are essentially unstudied. The presence of some lowdischarge springs in the Sierra Ancha and Mazatzal Mountains and base flow in several streams that drain those strata, including Rye Creek, Sycamore Creek, and Cherry Creek, suggest the existence of some mountain recharge sites. What is not known at present is the extent to which ground-water flow makes its way into the lower basin by way of faults and fractures within the Proterozoic rocks. In the Payson granite, most known water-bearing zones are shallow and are dependent on winter precipitation to sustain ground-water levels. The shallow granite aquifer has little or no connection with regional flow systems. Deeper water-bearing zones within the Payson granite, however, may be storing or transporting flow from the Mogollon Rim (Gæorama, Inc., 2003).

Other Proterozoic rocks in the study area probably have similar hydrologic characteristics in that they have extremely limited primary permeability but do have fracture-controlled secondary permeability. As indicated by the few low-flow springs and by the handful of shallow wells in Proterozoic rocks along the southeastern edge of Tonto Creek below the Mogollon Rim, the waterbearing zones are mainly shallow systems that are probably dependent on local winter precipitation to sustain water levels. These rocks may also include deepseated fractures through which ground water is transmitted from the regional ground-water systems. Although many of the Proterozoic faults and fracture systems may be too mineralized to allow significant fluid movement, some of those systems were reactivated during Basin and Range faulting and perhaps serve as conduits for ground-water flow. Within the study area, the upper reaches of all the major streams trend northeast along the same trend as the apparently fracture-controlled tributaries of the Little Colorado River on the Colorado Plateau or, in the case of Canyon and Cibecue Creeks, northwest-trending upper reaches nearly join the headwaters of the north-flowing plateau streams. Because the fractures on the plateau are through Paleozoic rocks, they are presumably either Basin and Range extensional structures or reactivated Proterozoic structures, and their continuation on the southern side of the Mogollon Rim is not improbable.

Within the basin fill and Quaternary alluvium of the lower Tonto Creek Basin, the shallow aquifer that is exploited by wells in the area is likely recharged from streamflow and precipitation. Generally higher dissolved solids concentrations in the wells of the lower Tonto Creek Basin, however, might be evidence of more evolved waters that have been transported from the regional ground-water system.

\section{Water Budget}

The water budget is a summation of all the inflows to and outflows from the ground-water system. In the Mogollon Highlands, the control volume represented by the $\mathrm{C}$ aquifer south of the ground-water divide is fairly well established (Hart and others, 2002) and inflow, almost entirely in the form of precipitation, can be constrained within tolerable limits. Although a 30-percent decrease in the flow of Canyon Spring after 


\section{Hydrology of the Mogollon Highlands, Central Arizona}

1992 (fig. 16A) offers some evidence of water-table decline in the $\mathrm{C}$ aquifer near the crest of the Mogollon Rim, the total volume of water in the aquifer has probably not fluctuated significantly in historic times and can be considered to be in steady-state condition. The limestone aquifer is not as well understood, however. The extent of the aquifer below the $\mathrm{C}$ aquifer is not known, nor is its recharge area well constrained. Although it is almost certainly recharged by vertical flow through large regional structures from the overlying $\mathrm{C}$ aquifer, the ground-water divide of the limestone aquifer, separating that part of the aquifer that flows toward the Mogollon Rim from that which flows toward the Little Colorado River, has not been delineated, and the degree of local recharge occurring on the lower slopes of the rim has not been established. Nonetheless, the persistence and consistency of flow from Fossil Springs and the rather steady base flow of Cibecue Creek, which drains the aquifer along the eastern edge of the study area, suggest that the volume of water in the aquifer does not fluctuate significantly over time, and it is probably reasonable to consider the volume as steady in the long term. For the purposes of this study, it is assumed that the $\mathrm{C}$ aquifer and limestone aquifer are hydraulically connected, that they share a common recharge area above the Mogollon Rim, and that only the limestone aquifer receives secondary recharge from precipitation falling below the Mogollon Rim crest and possibly from spring flow at higher altitudes that percolates back into channel bottoms above the limestone aquifer. Local water-bearing zones are not considered separately in this analysis.

\section{Ground-Water Budget Data and Approach}

The inflow data used in this study include recharge values estimated from areal precipitation totals using the PRISM geographic coverages (fig. 5) and published recharge rates for the Flagstaff area (Errol L.

Montgomery and Associates, 1993). Outflow data include spring-discharge and stream-discharge records.

The PRISM coverages consist of a map of contoured annual precipitation values that have been generated using point precipitation data and digital elevation models to model the spatial distribution of precipitation (Johnson and Taylor, 2003). The data are organized into polygons, which enables calculation of surface area over which a given value of average annual precipitation falls and which permits calculation of area-weighted annual precipitation.
Almost all the significant spring discharge is from the Paleozoic rocks of the Mogollon Rim, and these discharges were used to estimate the outflow from the $\mathrm{C}$ aquifer and limestone aquifer within those rocks (table 12). Values of average annual spring discharge were estimated from single point discharges where those were the only data available, or from averages of multiple measurements. Where there were great discrepancies between reported values for the same spring, estimated or anecdotal values were eliminated in favor of measured values when such were available. When using such scanty data, considerable error can be introduced into the estimates of annual spring discharge; however, the four springs or spring systems for which good, multiple measurements exist-Fossil Springs, Tonto Natural Bridge Spring, Tonto Spring, and Canyon Spring - account for about 75 percent of the total recorded spring discharge for the study area (table 4 , nos. 14, 22, 52, and 67). Discharge from non-carbonate springs generally is below $10 \mathrm{gal} / \mathrm{min}$, and such springs discharge an inconsequential portion of the total water budget for the aquifers within the Paleozoic sedimentary rocks. The precision and completeness of discharge data, or lack thereof, for low-discharge springs is, therefore, not of major concern. The most problematic records are for those springs that have demonstrated high but variable discharge during the few times they have been measured. These include Cold Spring, Big Spring, See Spring, and The Grotto (table 4, nos. 44, 37, 61, and 38). The difference between the extremes of range produce changes in the total outflow from the regional aquifers of 2 percent greater or 4 percent lower than the value obtained by using average or best values, as was done here.

For purposes of calculating the budget, averages of multiple measurements were used, except in the case of See Spring for which the highest value was discarded because technical notes on file in the USGS Tucson office indicate that runoff could be included in that estimate. Springs having discharges below $10 \mathrm{gal} / \mathrm{min}$ were not used in calculations of the water budget. Most of the smaller springs do not appear to issue from the regional aquifer but from local water-bearing rock zones.

Streamflow records for the six largest streams draining the study area were also used to calculate outflows from the $\mathrm{C}$ and limestone aquifers. On Cherry Creek and the East Verde River, records were used from two discontinued streamflow-gaging stations (fig. 1 and tables 2 and 12) that were near the base of the Mogollon Rim, near Young and Payson, respectively, and the short records there were extended by regression (table 13). 
Table 12. Stream-discharge, spring-discharge, and precipitation values used to compute water budget for regional aquifer

[ft $3 /$ s, cubic feet per second; ac-ft/yr, acre-feet per year; gal/min, gallons per minute; E, estimated; $\mathrm{C}$, current meter; V, volumetric; F, flume; R, reported; in., inches. All stream data from U.S. Geological Survey except where noted. Precipitation values are calculated from Parameter-elevation Regressions on Independent Slopes Model coverage (see fig. 5). Dashes indicate no data]

\begin{tabular}{|c|c|c|c|c|c|c|}
\hline Stream name & $\begin{array}{c}\text { Average daily } \\
\text { discharge } \\
\left(\mathrm{ft}^{3} / \mathrm{s}\right)\end{array}$ & $\begin{array}{l}\text { Average annual } \\
\text { discharge } \\
\text { (ac-ft/yr) }\end{array}$ & $\begin{array}{c}\text { Average annual } \\
\text { runoff } \\
\text { (ac-ft/yr) }\end{array}$ & $\begin{array}{c}\text { Average annual } \\
\text { base-flow } \\
\text { discharge } \\
\text { (ac-ft/yr) }\end{array}$ & $\begin{array}{c}\text { Average annual } \\
\text { spring flow into } \\
\text { drainage } \\
\text { (ac-ft/yr) }\end{array}$ & $\begin{array}{c}\text { Net base flow } \\
\text { (ac-ft/yr) }\end{array}$ \\
\hline \multicolumn{7}{|c|}{$\mathrm{C}$ aquifer drainage } \\
\hline $\begin{array}{l}\text { West Clear Creek near Camp } \\
\text { Verde }\end{array}$ & 63.55 & 46,041 & 31,794 & 14,247 & 1,614 & 12,633 \\
\hline \multicolumn{7}{|c|}{ Limestone aquifer drainage } \\
\hline East Verde River near Payson ${ }^{1}$ & 49.30 & 35,716 & 22,896 & 12,820 & 7,544 & 5,276 \\
\hline Tonto Creek at Bear Flat ${ }^{2}$ & 5.50 & 3,961 & 674 & 3,287 & 5,733 & ${ }^{5} 0$ \\
\hline Cherry Creek near Young ${ }^{1}$ & 6.92 & 5,012 & 1,651 & 2,312 & $\left({ }^{4}\right)$ & 2,312 \\
\hline Spring or station name & $\begin{array}{l}\text { Altitude } \\
\text { (ft above } \\
\text { NGVD 29) }\end{array}$ & Drainage & $\begin{array}{c}\text { Discharge } \\
\text { (gal/min) }\end{array}$ & $\begin{array}{l}\text { Year of latest } \\
\text { record }\end{array}$ & Method & $\begin{array}{c}\text { Annual } \\
\text { discharge } \\
\text { (ac-ft/yr) }\end{array}$ \\
\hline \multicolumn{7}{|c|}{ C aquifer springs } \\
\hline Buckhorn & 5,060 & West Clear Creek & 1,000 & 1959 & $\mathrm{E}$ & 1,614 \\
\hline Nappa & 6,620 & Tonto Creek & 70 & 1966 & $\mathrm{C}$ & 113 \\
\hline A-11-14 35DBA2 & 6,800 & Canyon Creek & 410 & -- & $\mathrm{C}$ & 662 \\
\hline Tonto & 6,480 & Tonto Creek & 1,291 & 2001 & Average F & 2,084 \\
\hline Canyon & & Canyon Creek & 2,224 & 2001 & Average F & 3,590 \\
\hline Total $^{3}$ & & & & & & 11,500 \\
\hline
\end{tabular}




\section{Hydrology of the Mogollon Highlands, Central Arizona}

Table 12. Stream-discharge, spring-discharge, and precipitation values used to compute water budget for regional aquiferContinued

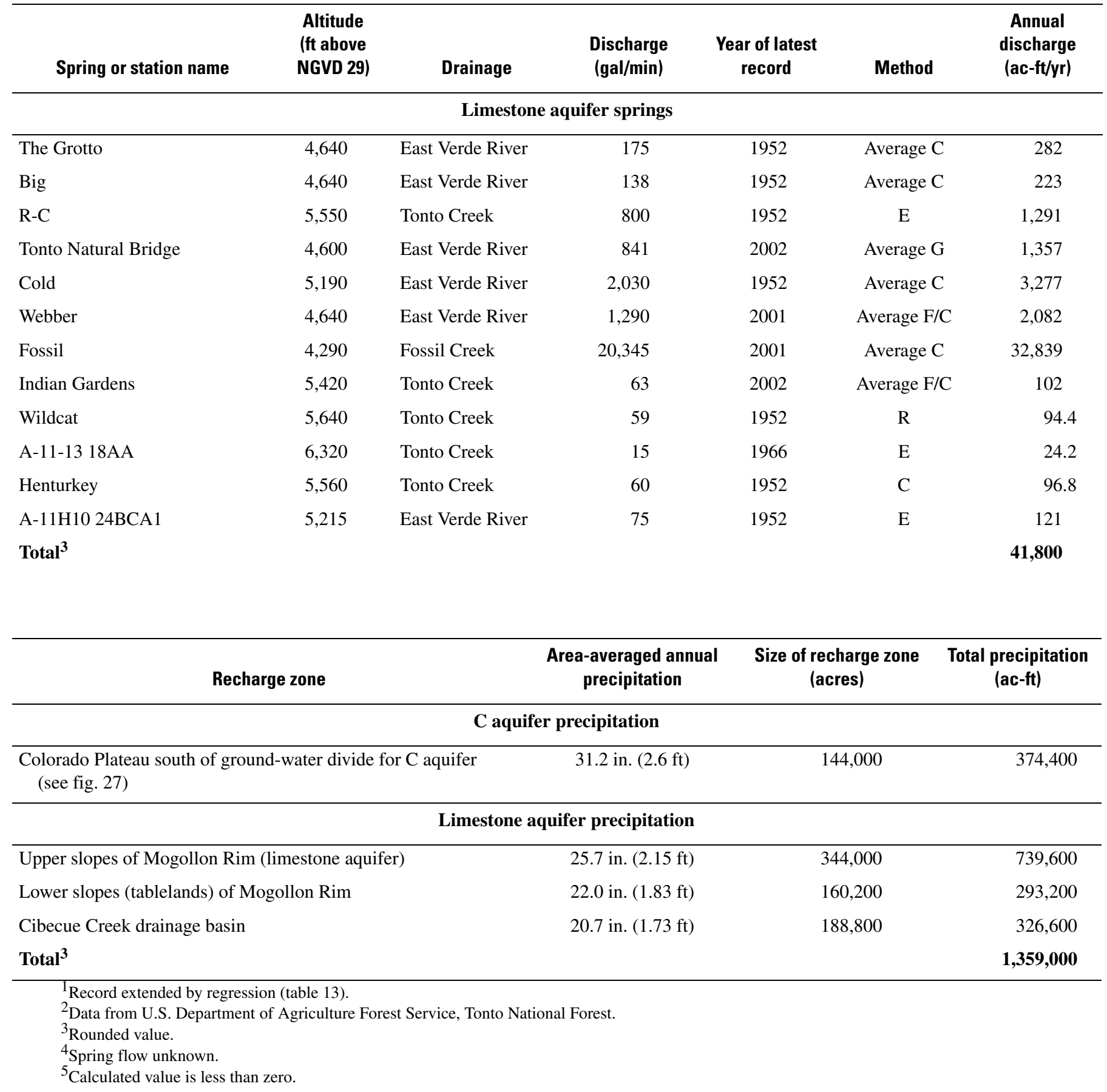

Table 13. Results of regression to extend stream records

\begin{tabular}{lllrr}
\hline \multicolumn{1}{c}{ Independent stream record $(\boldsymbol{x})$} & \multicolumn{1}{c}{ Dependent stream record $(\boldsymbol{y})$} & \multicolumn{1}{c}{ Dates used } & Equation & $\boldsymbol{r}^{2}$ \\
\hline Cherry Creek near Globe & Canyon Creek near Globe & $10-1-1975$ to 9-30-1981 & $y=2.34 x .956$ \\
Cherry Creek near Globe & Cherry Creek near Young & $5-4-1965$ to 9-30-1977 & $y=0.344 x-0.298$ \\
East Verde River near Childs & East Verde River near Payson & 9-19-1961 to 9-30-1965 & $y=0.737 x+0.614$ & .905 \\
\hline
\end{tabular}


These stations were used instead of the active stations because of their proximity to the Paleozoic rocks from which the ground-water discharges from the regional aquifers. At Tonto Creek, monthly low-flow measurements conducted by the USDA Forest Service at Bear Flat (fig. 1) were used to estimate base flow. West Clear Creek, Canyon Creek, and Cibecue Creek have no records other than from the stations close to the mouth of the streams. West Clear Creek flows most of its length through rocks that constitute the $\mathrm{C}$ aquifer, and it is reasonable to suppose that the ground-water component of base flow in these streams is derived from that aquifer. Cibecue Creek flows most of its length through the limestone aquifer and most of its base flow probably comes from those rocks.

Daily average streamflows were used to calculate a daily value of stream volume, and the average daily stream volume was used to calculate an average annual volume for the period of record (table 12). As described in the hydrology section, base flow was estimated to be the sum of all flows below the discharge level that occurred at the 80th percentile of total streamflow. For calculation of total outflow from each stream, estimated total annual discharge from springs upstream from the measurement site was subtracted from the total annual base flow to avoid double accounting of discharges (table 12).

\section{Inflows}

Total precipitation over the approximately $3,950 \mathrm{mi}^{2}$ of the study area south of the $\mathrm{C}$ aquifer ground-water divide parallel to the Mogollon Rim is more than 4.4 million acre-ft/yr. Most of that precipitation, however, does not occur over probable recharge zones. The main recharge area for the $\mathrm{C}$ aquifer and the minor water-bearing zones in the Schnebly Hill and Supai Formations occurs along the crest of the Mogollon Rim over an area of about $225 \mathrm{mi}^{2}$ that receives about 9 percent of the total precipitation for the Mogollon Highlands. The subdued topography, geologic structures, high winter precipitation, and a winter snowpack all promote high rates of infiltration and recharge relative to much of the rest of the study area. Errol L. Montgomery and Associates (1993) estimated that 4 to 17 percent of precipitation was recharged into the regional aquifer near Flagstaff in an area of geology similar to that in the study area. A 17-percent recharge rate was initially used to calculate the total recharge on the crest of the Mogollon Rim (table 14A).
The limestone aquifer is recharged by leakage from the overlying $\mathrm{C}$ aquifer and by local recharge-precipitation falling on areas below the recharge area for the $\mathrm{C}$ aquifer but above the limestone aquifer. Although more precipitation-18 percent of the total for the study area-falls on the face of the Mogollon Rim than on the crest, steeper slopes; thinner soils; lower, less dependable, less persistent snow accumulation; and less permeable geologic units result in a higher percentage of the total being lost to runoff. A recharge rate of 4 percent to the regional aquifer was initially assumed for the steepest slopes of the Mogollon Rim (table 14A).

In the tablelands forming the base of the Mogollon Rim, slopes are more subdued. Soils are typically thin, and geologic units generally are of low permeability, except where fractured or weathered. The tablelands are near the bottom of the winter snowline and snow accumulations are so light and of such brief duration that they are probably not a significant factor in recharge. Nonetheless, evidence cited above, including isotopic values and spring-flow instability, suggest some local recharge occurs. A recharge rate of 4 percent of total precipitation was assumed for the tablelands although the local variation over the entire area certainly is quite high. Because of the characteristics of the Cibecue Creek watershed, namely generally subdued topography and permeable geologic units, a recharge rate of 10 percent was initially used for precipitation in that basin (table 14A). The Mazatzal Mountains and the Sierra Ancha and highlands to the east receive, respectively, about 4.5 and 10 percent of the total precipitation in the study area (figs. 1 and 5). These mountainous areas have more subdued slopes than the face of the Mogollon Rim, which might promote greater recharge relative to runoff although the Proterozoic rocks have little permeability except where fractured. Mountain-front recharge along the eastern edge of the Mazatzal Mountains and the western edge of the Sierra Ancha likely occurs to the alluvial aquifer of the lower Tonto Creek Basin. Recharge probably also occurs to the alluvial aquifer from precipitation on the valley floor because of the subdued topography and permeability of sediments at the land surface. No attempt is made here to quantify a regional water budget for that part of the study area in the generally Proterozoic rocks below the base of the Mogollon Rim. Except for the Payson granite, there are too few data to incorporate that terrane into a regional budget, and for the most part, those rocks are not hydraulically connected to the regional aquifers beneath the Mogollon Rim. 


\section{Hydrology of the Mogollon Highlands, Central Arizona}

Table 14. Summation of water inflows and outflows for $\mathrm{C}$ aquifer and limestone aquifer

[Values are in acre-feet per year]

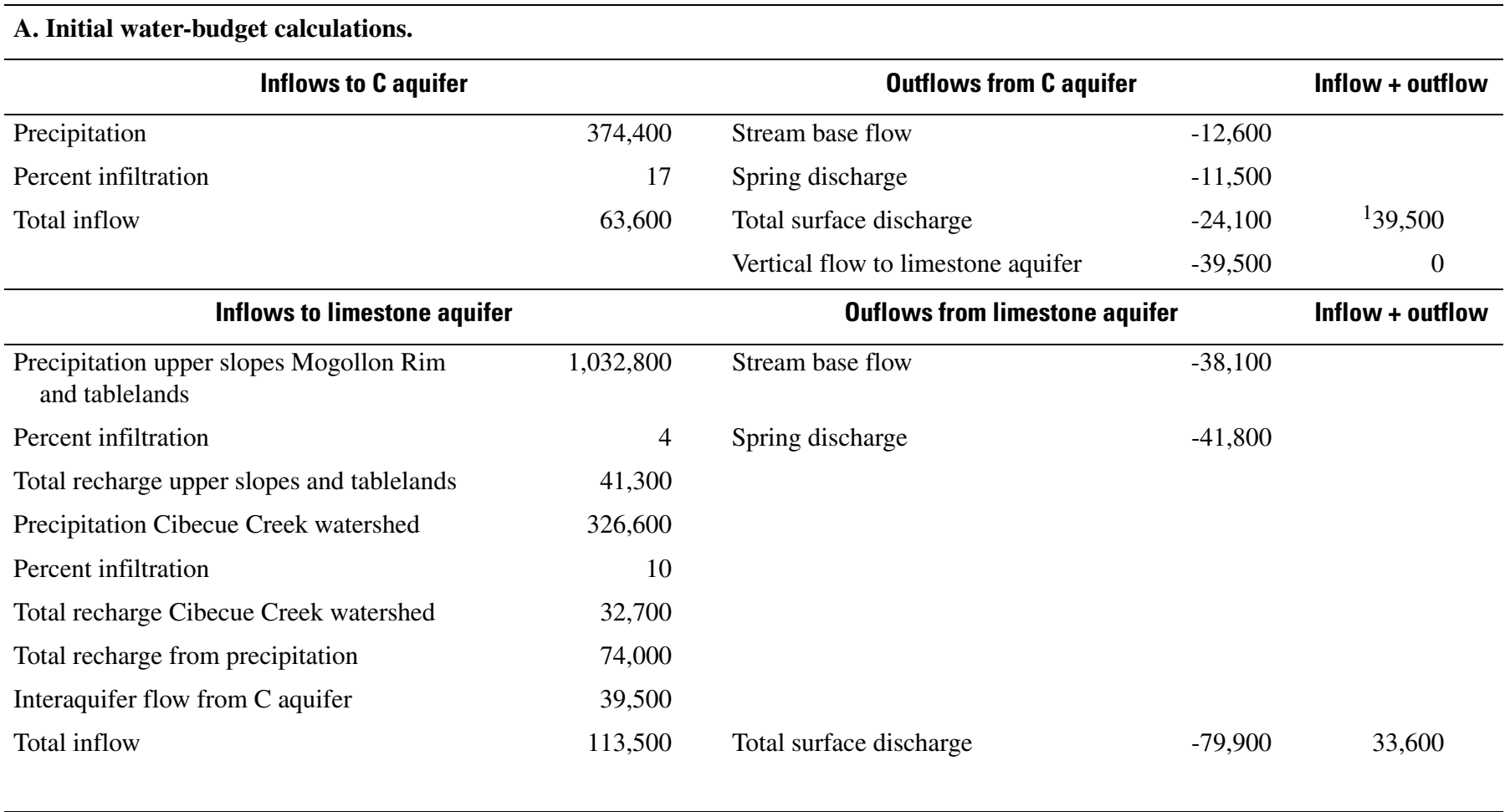

B. Iteration of water-budget calculations using lower estimates of infiltration of precipitation.

\begin{tabular}{|c|c|c|c|c|}
\hline Inflows to $C$ aquifer & & Outflows from $\mathrm{C}$ aquifer & & Inflow + outflow \\
\hline Percent infiltration & 15 & & & \\
\hline Total inflow & 56,200 & Total surface discharge & $-24,100$ & 32,100 \\
\hline Inflow to limestone aquifer & & \multicolumn{2}{|l|}{ Outflows from limestone aquifer } & Inflow + outflow \\
\hline Percent infiltration & 2 & & & \\
\hline Total recharge upper slopes and tablelands & 20,700 & & & \\
\hline Precipitation Cibecue Creek watershed & 326,600 & & & \\
\hline Percent infiltration & 8 & & & \\
\hline Total inflow & 78,900 & Total surface discharge & $-79,900$ & $-1,000$ \\
\hline
\end{tabular}

${ }^{1}$ Vertical ground-water flow to limestone aquifer. 


\section{Outflows}

Spring discharge and stream base flow account for the greatest component of outflow, except for evapotranspiration and runoff, which account for the 83 to 98 percent of precipitation that does not recharge the ground-water system (fig. 27 and table 14). Almost all the spring discharge results from a handful of highvolume springs in carbonate rocks on the face of the Mogollon Rim or in the tablelands below the face (fig. 15 and table 12). Water use is not considered because almost all ground-water for domestic use is taken from shallow, local water-bearing zones rather than from the regional aquifers, and the total reported water use from the entire study area, not just the Mogollon Rim, is less than 2,400 acre-ft/yr, which is inconsequential in a regional context.

The $\mathrm{C}$ aquifer discharges mainly from nine springs that emit from the Schnebly Hill Formation, probably from the Fort Apache Member, and from Buckhorn Spring, which discharges from the Coconino Sandstone in the West Clear Creek drainage (table 12). The stability of spring flow is known only for Tonto Spring and Canyon Spring; however, Christopher Creek and upper Tonto Creek are both perennial streams suggesting that additional springs in those headwaters probably are perennial. West Clear Creek, which is the other most significant source of discharge from the $\mathrm{C}$ aquifer in the study area, maintains a minimum base flow of $11 \mathrm{ft}^{3} / \mathrm{s}$ that indicates it derives from a ground-water source with a large contributing area that has not been affected by climatic fluctuations or well pumpage during the period of record. Most other streams originate well up on the Mogollon Rim, but are ephemeral upstream from springs and do not appear to have any significant ground-water discharge to their channels except from springs. Stream base flow, therefore, is not considered a significant source of $\mathrm{C}$ aquifer discharge for any channel except West Clear Creek.

Discharge from the $\mathrm{C}$ aquifer in the study area calculated here is 62 percent of the estimated recharge (fig. 14A). Possible reasons for excess of recharge over discharge include an overly high estimate of the percentage of precipitation recharged, unmeasured spring discharge, drainage through base flow in streams other than West Clear Creek, and vertical flow from the $\mathrm{C}$ aquifer into local water-bearing zones or into the limestone aquifer or both. Because of the generally high permeability of fractured rocks on the Colorado Plateau and the subdued topography, a substantially lower estimate of recharge does not seem warranted.
Also unlikely is the chance that sizeable springs with no record of discharge exist within the study area. Some ground-water discharge into stream channels in addition to spring discharge that has been accounted for is not unlikely, especially in Cibecue Creek and Canyon Creek. Because there are no data available that would enable partitioning of ground-water flow in those streams between the $\mathrm{C}$ and limestone aquifers, all flow here is assumed to come from the limestone aquifer except for that discharging from the springs at the head of Canyon Creek. The entire reach of Cherry Creek on the face of the Mogollon Rim is ephemeral, indicating that flow is almost entirely runoff with no significant ground-water contribution. The Forest Service has measured the flow of Tonto Creek below the Mogollon Rim, and the amount of base flow was nearly equivalent to the combined discharge of springs in upper Tonto Creek and its tributaries, indicating that there is not a significant ground-water contribution to the channel from either the $\mathrm{C}$ or limestone aquifer other than spring flow (table 12). There are no data to determine the extent to which flow of the East Verde River is maintained by the $\mathrm{C}$ aquifer beyond spring discharge, and all base flow in excess of spring discharge is assumed to come from the limestone aquifer. Because of the chemical and discharge data referred to above, the $\mathrm{C}$ aquifer is considered to be the source of most flow that discharges from the underlying limestone aquifer. The excess outflow over inflow of $39,500 \mathrm{acre}-\mathrm{ft} / \mathrm{yr}$ for the $\mathrm{C}$ aquifer is, therefore, believed to be accounted for by vertical flow from that aquifer into the limestone aquifer (table 14A and fig. 27).

High-discharge springs below the Supai Formation drain the limestone aquifer. Almost 80 percent of spring discharge from the limestone aquifer is from Fossil Springs. The other significant drain is Cibecue Creek (table 12 and fig. 27). The high percentage of Cibecue Creek streamflow that is attributable to base flow indicates a ground-water component. As mentioned above, some of the Cibecue Creek flow may be directly from the $\mathrm{C}$ aquifer; however, data are not available to determine the percentage of total Cibecue Creek flow, if any, that comes from the $\mathrm{C}$ aquifer. That a sizeable component does come from the limestone aquifer is indicated by the incision of Cibecue Creek into the rocks of the middle and lower Paleozoic sedimentary rocks and the presence of numerous springs in those rocks along the length of the channel.

The regional water budget constructed from these data show a surplus of recharge in the $\mathrm{C}$ aquifer, which is presumed to be recharged into the limestone aquifer, and a surplus of discharge from the limestone aquifer, and 


\section{Hydrology of the Mogollon Highlands, Central Arizona}

therefore from the entire regional ground-water system, of 33,600 acre-ft/yr, about 24 percent of the combined recharge from precipitation that is estimated for the two aquifers (table 14A). If all the estimates of inflows and outflows used in calculation of the budget are reasonably accurate, the results would indicate that storage within the regional aquifers is increasing. There is no evidence, however, to suggest that this is the case. As noted above, a recent decrease in discharge from Canyon Spring could indicate that the water table at the top of the $\mathrm{C}$ aquifer has been lowered, but that would argue for a negative change in storage within the $\mathrm{C}$ aquifer rather than an increase. The surplus of inflow over outflow must, therefore, be the result of overestimates of inflow or underestimates of outflow.

Several errors can account for the discrepancy, however, most of the likely errors would produce an even greater excess of inflow over outflow. The most question-able estimates include the amount of base flow and spring flow that drain the two aquifers. As noted above, spring-flow values are probably reasonably accurate for four spring systems that account for 75 percent of the spring discharge from the Mogollon Rim. In the unlikely event that all other discharges are closer to the maximum value recorded rather than the mean or best values used in this report, the total increase in estimated spring discharge would be about 5,600 acre$\mathrm{ft} / \mathrm{yr}$. No net gain in outflows would be realized, however, because spring discharges have been subtracted from base flows in the streams into which the springs discharge. The only exception is Fossil Springs. No baseflow estimate is available for Fossil Creek and an increase in the estimated annual discharge from those springs would increase the net outflow. Records on Fossil Creek are reasonably good and consistent over time, and low variability of discharge from those springs (table 5) indicates that the estimate of annual spring discharge cannot be significantly increased.

An increase in base flow in the streams draining the Mogollon Rim would produce an increase in net outflow. For the East Verde River and Cherry Creek, a conservative value of base flow was estimated by using the brief discharge records at discontinued stations that were near the base of the Mogollon Rim (table 12). Tonto Creek base flow was calculated from a series of monthly low-flow measurements and the value achieved might be lower than the long-term average. Nonetheless, even a 75-percent increase in the value of base flow on Tonto Creek at the base of the Mogollon Rim would result in a net zero discharge once the values of annual spring discharge are subtracted from the base flow (table 12). The rationale for using those records, rather than the long-term records at stations near the mouth of the streams, is the assumption that there is little significant ground-water flow from the regional aquifers entering stream channels from the Proterozoic rocks below the Mogollon Rim. As noted above, there is some evidence of major regional joints or faults that are continuous from beneath the Mogollon Rim into the Proterozoic terranes to the south that could serve as conduits for ground-water flow into the lower reaches of stream channels. Also, base flow calculated at Tonto Creek at Bear Flat is nearly 2,400 acre-ft/yr lower than the total estimated spring discharge entering the channel upstream. The loss of flow could be the result of leakage into deep fractures within the Proterozoic rocks that emerges in the channel farther downstream as well as some combination of evapotranspiration losses from the channel and over-estimates of total annual spring discharge. Considering the dearth of evidence, the existence of ground-water flow into the lower reaches of stream channels within the study area is still speculative, and its inclusion in a regional water budget is not justified. Indeed, given the flashy nature of streamflow in the Mogollon Highland streams, the component of ground-water flow in those streams occurring as base flow is more likely to be overestimated here than underestimated.

More likely sources of error are those that would produce an overestimate of inflows into the hydrologic system. These would include an overestimate in the contributing area to the regional aquifers, an overestimate in the total precipitation, and overestimates of the percentage of total recharge. Any changes in these estimates are somewhat arbitrary, but reasonable as long as such changes allow for an excess of inflow into the $\mathrm{C}$ aquifer because, on the basis of the evidence noted above, that aquifer is the source for much of the ground water that discharges from the limestone aquifer. Consequently, a minimal reduction in estimates of inflow to the $\mathrm{C}$ aquifer is warranted. Reducing the estimate of the recharge rate from 17 to 15 percent would produce a total recharge to the $\mathrm{C}$ aquifer of 53,300 acre- $\mathrm{ft} / \mathrm{yr}$ and total excess of inflow over outflow of 29,200 acre-ft/yr, which would enter the limestone aquifer by vertical flow (table 14B). This would reduce the total excess of inflow over outflow for the limestone aquifer to 23,100 acre-ft/yr. The most likely source of error accounting for the remaining excess is probably in the estimated rate of local recharge from precipitation to the limestone aquifer. Reducing the estimated rate of local recharge by 2 percent for precipitation falling on the 
face of the Mogollon Rim, the tablelands, and the Cibecue Creek watershed, results in a reduction in total discharge that produces a water budget with a deficit of $1,000 \mathrm{acre}-\mathrm{ft} / \mathrm{yr}$, which is less than 1 percent of the combined recharge from precipitation for the $\mathrm{C}$ and limestone aquifers (table 14B). Further adjustments could be made to achieve a perfectly balanced budget, but considering the potential errors in hydrologic measurements, there seems to be little reason to do so. The adjustments that were made are not necessarily the correct adjustments, but they are reasonable and demonstrate how small changes in estimates of the various components of the water budget can produce substantial changes in the total regional budget.

\section{Additional Data Needs}

Among the topics that cannot be adequately answered with current data are (1) the short- and longterm water-level fluctuations in shallow wells, lowdischarge springs, and tributary streams that discharge from local aquifers; (2) the short- and long-term waterlevel fluctuations in deeper wells that tap the regional aquifers; (3) the characteristics of the limestone aquifer along Canyon and Cibecue Creeks where the creeks flow through the Fort Apache Indian Reservation; (4) the short- and long-term behavior of high-discharge springs discharging from regional aquifers;

(5) delineations of ground-water flow paths and the potentiometric surface of the limestone aquifer;

(6) the degree to which ground water recharged on the Mogollon Rim crest and slopes intrudes into the Proterozoic rocks and alluvium of the lower parts of the study area; and (7) the relative length of ground-water flow paths and residence time within the $\mathrm{C}$ and limestone aquifers along the face of the Mogollon Rim.

An extensive well-monitoring program is being conducted by the town of Payson in water-bearing zones of the Payson granite and related Proterozoic rocks. Expansion of well monitoring in the Pine-Strawberry area and in other communities with relatively high well density would begin to provide data necessary for evaluating the effects of water-resources development and climatic variability in other local aquifers.

Monitoring low-discharge springs and tributary streams is necessary if any quantitative relation among climatic fluctuations, water-resources development, and groundwater surface-water interactions is to be developed. Such springs and streams primarily drain local aquifers, which are also the most heavily utilized aquifers for water use in the Mogollon Highlands.

Although there is a paucity of wells below the crest of the Mogollon Rim deeper than $300 \mathrm{ft}$, more may become available as water providers, especially in the Pine-Strawberry area, seek more dependable sources of ground water. If this resource, which to date has been little exploited and is not well described, is to be more fully developed, monitoring of water levels would be desirable to identify how the ground-water system responds to development and climate change. Above the Mogollon Rim, additional monitoring of wells that draw from the $\mathrm{C}$ aquifer could provide early warning of watertable declines as a result of drought or increased development. Because several high-discharge springs in the study area flow from near the top of the ground-water mound, short- or long-term declines in the water table in this area could have detrimental effects on streamflow below those springs.

Monitoring of high-discharge spring flow could range from continuous monitoring to semiannual or quarterly measurement of high-discharge springs mainly on the East Verde River and its tributaries and on Tonto and Christopher Creeks. The more infrequent the measurements, the longer the record needed to assess the variability of such flows.

Mapping the potentiometric surface of the limestone aquifer to subsequently develop an understanding of ground-water flow paths would require considerable new well development and confirmation that those wells are in fact within the limestone aquifer. Because most of the study area is within public lands, and because the most critical water needs are primarily in the PineStrawberry area where the limestone aquifer is at considerable depths, such information can be acquired as economic realities allow. An inventory of existing wells in the East Verde River and Tonto Creek watersheds to confirm water levels and to ascertain whether or not they are in the limestone aquifer might improve understanding of flow paths and extend mapping of the potentiometric surface in that area. The degree to which regional groundwater flows through fractures in Proterozoic rocks below the Mogollon Rim would also require additional well development. The town of Payson has conducted some investigations, but there is little impetus for significant deep-well development in the Proterozoic rocks in the southern part of the study area. Additional analysis of geophysical data might also improve understanding of the regional fracture and fault system at depth, which would help in the interpretation of probable ground-water 
flow paths. Finally, seepage runs along Cherry and Tonto Creeks, and the East Verde River below the Mogollon Rim would identify losing and gaining reaches in those streams as they flow through Proterozoic terrane and further clarify the extent to which they are recharged, either locally or from the regional system in their lower reaches. Characterization of the limestone aquifer on lower Canyon and Cibecue creeks would require a cooperative effort with the Fort Apache tribal government.

Dating of spring waters could provide some indication of the relative lengths of ground-water flow paths, residence time of water, and the degree of mixing with younger waters as a result of local recharge.

\section{Summary and Conclusions}

The Mogollon Highlands receive an average annual precipitation of $21.3 \mathrm{in}$, and nearly twice that amount at the highest altitudes where most recharge takes place. Nonetheless, the geologic characteristics of the region serve to limit the availability of water resources. The only area of significant ground-water storage is above the Mogollon Rim where the $\mathrm{C}$ aquifer comprises the Coconino Sandstone and Schnebly Hill Formation. The subdued topography and the highly fractured rocks of the Coconino Sandstone (and, where present, the Kaibab Formation, or Tertiary volcanic rocks, or both that overlie the Coconino) facilitate recharge on the Colorado Plateau along the crest of the Mogollon Rim. Most of the water that reaches the Mogollon Highlands ground-water system flows through the $\mathrm{C}$ aquifer, either vertically or horizontally. The $\mathrm{C}$ aquifer is drained by high-discharge springs that flow into the East Verde River, and Tonto, Christopher, Canyon, and West Clear Creeks. Flow to these springs occurs along fracture systems, possibly enlarged by dissolution, in the Schnebly Hill Formation and mainly in the Fort Apache Member of that formation. Springs near the base of the Mogollon Rim discharge from the limestone aquifer. Although the limestone and $\mathrm{C}$ aquifers are separated by the Supai Formation, a confining unit, the persistent high volume of flow discharging from Fossil Springs, and the chemical signatures of those springs and others that discharge from the limestone aquifer indicate a relation to waters of the $\mathrm{C}$ aquifer. The low specific conductances and isotopic signatures of spring waters suggests that flow paths are short and travel times rapid.
Precipitation falling outside the main recharge area of the study area mainly is lost to runoff and evapotranspiration because of the general impermeability of the rocks that form the Mogollon Rim and because of the steep slopes of the rim face. Streamflow within the study area tends to be flashy because of bedrock channels, narrow or nonexistent flood plains, and steep slopes. Base flow in most streams is less than 30 percent of total flow. In the Proterozoic terrane below the Mogollon Rim, ground-water contributions to flow are probably minimal. Cibecue Creek on the eastern edge of the study area has a base-flow component of greater than 50 percent, which suggests a more significant ground-water contribution, probably from the limestone aquifer that discharges into the channel or underlies it through most of its length. Some precipitation recharges local, shallow aquifers in the Paleozoic sedimentary rocks and in the Proterozoic rocks below the Mogollon Rim. These aquifers tend to be the most heavily developed within the study area and are also most susceptible to fluctuations in water level as a result of climatic variability and ground-water withdrawals. Several wells in the Payson area, where the most data on water levels over time are available, show sharp declines in water-level altitudes beginning in the mid-1990s with the onset of the drought that was occurring coincident with the study period for this project.

The regional aquifers are more resistant to shortterm climatic fluctuations as indicated by the stability of flow in the high-discharge springs draining those aquifers. A decline in average discharge of Canyon Spring above Canyon Creek in the mid-1990s, however, could indicate a lowering of the water-table altitude of the $\mathrm{C}$ aquifer as a result of the drought. The spring discharges from near the top of the $\mathrm{C}$ aquifer and can be expected to be sensitive to changes in water-table altitude. The stability of Fossil Springs and other highdischarge springs that drain the limestone aquifer also points to resistance to short-term climatic fluctuations; however, the discharges of springs along the East Verde River and its tributaries have demonstrated significant variability. Such variability may be the result of differences in flow paths or the spatial relations between spring mouths and the water table in the limestone aquifer.

Inflows to regional aquifers are approximately balanced by outflows. Leakage from the $\mathrm{C}$ aquifer is estimated to account for about 37 percent of the inflows into the limestone aquifer. Although initial calculations showed a surplus of inflow over outflow from the regional aquifers, reasonable modification of estimates of contributing area and recharge rates produced a balanced water budget for the study area. 


\section{References Cited}

AGRA Earth and Environmental, Inc., 1999, Groundwater resource evaluation Payson-Heber Highway (SR 260) upgrading project, Gila County, Arizona: Report to Arizona Department of Transportation, 3 vols.

Back, William, 1961, Techniques for mapping of hydrogeologic facies: U.S. Geological Survey Professional Paper 424D, p. 380-382.

Bills, D.J., Truini, Margot, Flynn, M.E., Pierce, H.A., Catchings, R.D., and Rymer, M.J., 2000, Hydrogeology of the regional aquifer near Flagstaff, Arizona, 1994-97: U.S. Geological Survey Water-Resources Investigations Report 00-4122, 143 p.

Bilodeau, W.L., 1986, The Mesozoic Mogollon Highlands, Arizona-An early Cretaceous rift shoulder: Journal of Geology, v. 94, p. 724-735.

Blakey, R.C., 1990, Stratigraphy and geologic history of Pennsylvanian and Permian rocks, Mogollon Rim region, central Arizona and vicinity: Geological Society of America Bulletin, v. 102, no. 9, p. 1189-1217.

Brew, D.S., 1965, Stratigraphy of the Naco Formation (Pennsylvanian) in central Arizona: Ithaca, New York, Cornell University, Ph.D. dissertation, 230 p.

Brown, D.E., Carmony, N.B., and Turner, R.M., 1981, Drainage map of Arizona showing perennial streams and some important wetlands: Phoenix, Arizona Fish and Game Department, 1 sheet.

Conway, C.M., 1976, Petrology, structure, and evolution of a Precambrian volcanic and plutonic complex, Tonto Basin, Gila County, Arizona: Pasadena, California Institute of Technology, Ph.D. dissertation, 460 p.

Conway, C.M., and Silver, L.T., 1989, Early Proterozoic rocks (1710-1615 Ma) in central to southeastern Arizona in Geologic evolution of Arizona, J.P. Jenney and S.J. Reynolds, eds., Arizona Geological Society Digest v. 17, p. 165-186.

Corkhill, Frank, 2000, Report on the drilling of an exploratory borehole near Strawberry, Arizona (May 18-June 2, 2000): Hydrogeologic investigation for the Northern Gila County Water Plan Alliance, Phoenix: Phoenix, Arizona Department of Water Resources, $33 \mathrm{p}$.

Cox, Rónadh, Martin, M.W., Comstock, J.C., Dickerson, L.S., Eckstrom, I.L., and Sammons, J.H., 2002, Sedimentology, stratigraphy, and geochronology of the Proterozoic Mazatzal Group, central Arizona: Geological Society of America Bulletin, v. 114, no. 12, p. 1535-1549.

Craig, Harmon, 1961, Isotopic variations in meteoric waters: Science, v. 133, p. 1702-1703.

DeGomez, Tom, 2002, Pine bark beetle outbreak in Arizona: Tucson, University of Arizona Cooperative Extension Forest Health Working Group and Arizona Bark Beetle Task Force, accessed October 15, 2003, at http://cals.arizona.edu/ coconino/assets/pdffiles/Winter2003BArkBeetles.pdf
DeGomez, Tom, 2003, Pine bark beetle outbreak in Arizona: Tucson, University of Arizona Cooperative Extension Forest Health Working Group and Arizona Bark Beetle Task Force, accessed October 15, 2003, at http://www.wildfire lessons.net/Library/Fire_Behavior_Research/April2003 BArkBeetles.doc

Denis, E.E., 1981, Map showing ground-water conditions in the Tonto Basin area, Gila County, Arizona-1979: U.S. Geological Survey Water-Resources Investigations OpenFile Report 82-116.

Errol L. Montgomery and Associates, 1993, Results of a 90-day aquifer test and ground-water flow model projections for long-term ground-water yield for the Coconino-Supai aquifer Lake Mary well field, Coconino County, Arizona: Tucson, Arizona, Errol L. Montgomery and Associates report prepared for the City of Flagstaff, $185 \mathrm{p}$.

Farrar, C.D., 1980, Ground-water potential in the middle Paleozoic carbonate rocks, Flagstaff area, Coconino County, Arizona: Flagstaff, Northern Arizona University, master's thesis, $91 \mathrm{p}$.

Fenneman, N.M., 1931, Physiography of western United States: New York, McGraw-Hill Inc., 534 p.

Feth, J.H., and Hem, J.D., 1963, Reconnaissance of headwater springs in the Gila River drainage basin: U.S. Geological Survey Water-Supply Paper 1619-H, 54 p.

Freethey, G.W., and Anderson, T.W., 1986, Predevelopment hydrologic conditions in the alluvial basins of Arizona and adjacent parts of California and New Mexico: U.S. Geological Survey Hydrologic Investigations Atlas HA-664, 3 sheets, scale 1:500,000.

Gæorama, Inc., 2001, Structural geology and groundwater exploration, Mayfield Canyon area, Gila County, ArizonaDiamond Rim Groundwater Exploration Program Phase I: Blanding, Utah, Report for Town of Payson, Gæorama, Inc., $16 \mathrm{p}$.

Gæorama, Inc., 2003, Structural geology and groundwater potential, Diamond Rim study area, Gila County, ArizonaDiamond Rim Groundwater Exploration Program:

Blanding, Utah, Report for Town of Payson, Gæorama, Inc., $47 \mathrm{p}$.

Hart, R.J., Ward, J.J., Bills, D.J., and Flynn, M.E., 2002, Generalized hydrogeology and ground-water budget for the $\mathrm{C}$ aquifer, Little Colorado River Basin and parts of the Verde and Salt River Basins, Arizona and New Mexico: U.S. Geological Survey Water-Resources Investigations Report 02-4026, 47 p.

Hereford, Richard, 1977, Deposition of the Tapeats Sandstone (Cambrian) in central Arizona: Geological Society of America Bulletin, v. 88, p. 199-211. 


\section{Hydrology of the Mogollon Highlands, Central Arizona}

Higgins, C.G., 1990, Seepage induced cliff recession and regional denudation with case studies by Osterkamp, W.R. and Higgins, C.G., in Groundwater geomorphology-The role of subsurface water in the Earth-surface processes and landforms, C.G. Higgins and D.R. Coates, eds.: Boulder, Colorado, Geological Society of America Special Paper 252, p. 291-317.

Hopkins, R.L., 1990, Kaibab Formation in Grand Canyon Geology, S.S. Beus and Michael Morales, eds.: Oxford, New York, Oxford University Press, chpt.11, p. 225-245.

Johnson, Greg, and Taylor, George, 2003, The NRCS PRISM Climate Mapping Project: Oregon Climate Service, Corvallis, Oregon State University, accessed November 10, 2003, at http://www.ocs.orst.edu/prism/przfact.html

Karlstrom, K.E., Bowring, S.A., and Conway, C.M., 1987, Tectonic significance of an Early Proterozoic two-province boundary in central Arizona: Geological Society of America Bulletin, v. 99, p. 529-538.

Kaczmarek, M.B., 2003, Investigation of groundwater availability for the Pine/Strawberry Water Improvement District: Helena, Montana, Morrison Maierle, 148 p.

Mann, L.J., and Nemecek, E.A., 1983, Geohydrology and water use in southern Apache County, Arizona: Phoenix, Arizona Department of Water Resources Bulletin 1, 86 p.

Mayer, Larry, 1979, Evolution of the Mogollon Rim in central Arizona: Tectonophysics, v. 61, p. 49-62.

Mayes, H.B., 1990, Cenozoic stratigraphy and depositional history of the northern Tonto Basin, Gila County, Arizona: Flagstaff, Northern Arizona University, master's thesis, $113 \mathrm{p}$.

McKee, E.D., and Gutschick, R.D., 1969, History of the Redwall Limestone of northern Arizona: Geological Society of America Memoir 114, $726 \mathrm{p}$.

Monroe, Stephen, 2002, Travertine and concrete-A geomorphological and historical study of a damsite at Fossil Creek, Arizona: Flagstaff, Northern Arizona University, master's thesis, $139 \mathrm{p}$.

National Climate Data Center, 2003a, U.S. monthly surface data: National Oceanic and Atmospheric Administration, accessed March 26, 2003, at http://www5.ncdc.noaa.gov/ cgi-bin/script/webcat.pl?action=ALL

National Climate Data Center, 2003b, Climate of 2002Annual review of U.S. drought: National Oceanic and Atmospheric Administration, accessed October 26, 2003, at http://www.ncdc.noaa.gov/oa/climate/research/2002/ann/ drought-summary.html

National Climate Data Center, 2003c, Palmer hydrologic drought index-October 2002 to September 2003: National Oceanic and Atmospheric Administration, accessed October 26, 2003, at http://lwf.ncdc.noaa.gov/oa/climate/ research/prelim/drought/phdiimage.html

Northern Gila County Historical Society, 1984, Rim Country history: Payson, Arizona, Rim Country Printing, 194 p.
Owen-Joyce, S.J., and Bell, C.K., 1983, Appraisal of water resources in the upper Verde River area, Yavapai and Coconino Counties, Arizona: Phoenix, Arizona Department of Water Resources Bulletin 2, 219 p.

Peirce, H.W., Damon, P.E., and Shafiqullah, M., 1979, An Oligocene(?) Colorado Plateau edge in Arizona: Tectonophysics, v. 61, p. 1-24.

Ploughe, Michael, 2000, North Payson area hydrogeological investigation results: Payson, Arizona, Town of Payson Groundwater Exploration Program, $10 \mathrm{p}$.

Ploughe, Michael, 2001, Town of Payson ground-water management 2001 status report: Payson, Arizona, Town of Payson Water Department, $12 \mathrm{p}$.

Pope, G.L., Rigas, P.D., and Smith, C.F., 1998, Statistical summaries of streamflow data and characteristics of drainage basins for selected streamflow-gaging stations in Arizona through water year 1996: U.S. Geological Survey Water-Resources Investigations Report 98-4225, 907 p.

Reynolds, S.J., 1988, Geologic map of Arizona: Tucson, Arizona Geological Society, Map 26, scale 1:1,000,000.

Richards, A.M., 1987, Gravity analysis of the Tonto and Payson basins, central Arizona: Flagstaff, Northern Arizona University, master's thesis, $162 \mathrm{p}$.

Ross, P.P., 1977, Map showing ground-water conditions in the Lower Verde River area, Maricopa, Yavapai, and Gila Counties, Arizona-1976: U.S. Geological Survey WaterResources Investigations 77-113, Open-File Report.

Sellers, W.D., Hill, R.H., and Sanderson-Rae, Margaret, eds., 1985, Arizona climate-The first hundred years: Tucson, University of Arizona Press, $80 \mathrm{p}$.

Southwest Ground-water Consultants, Inc., 1998, Long-term management program of the town of Payson's water resources: Report for Town of Payson: Phoenix, Southwest Ground-water Consultants, Inc., 61 p.

Teichert, Curt, 1965, Devonian rocks and paleogeography of central Arizona: U.S. Geological Survey Professional Paper 464, $181 \mathrm{p}$.

Twentner, F.R., 1962, The significance of the volcanic rocks in the Fossil Creek area, Arizona in Guidebook of the Mogollon Rim region east-central Arizona, New Mexico Geological Society, 13th Field Conference, October 18-20, 1962: New Mexico Geological Society, p.107-108.

U.S. Census Bureau, 2000, Data set: Census 2000 summary file 1 (SF 1) 100-percent data, Gila County, Arizona, Payson and Tonto census county divisions and Payson town, accessed July 22, 2004, at http://factfinder.census.gov/ servlet/DTGeoSearchByListServlet?ds_name=DEC_2000_ SF1_U\&_lang=en\&_ts $=113764036685$

U.S. Department of Agriculture, Forest Service, 2003, Draft environmental impact statement for the Rodeo-Chediski fire salvage project, Apache-Sitgreaves and Tonto National Forests: Apache-Sitgreaves National Forests, Springerville, Arizona, Rodeo-Chediski Fire Salvage Team, 399 p. 
Weir, G.W., and Beard, L.S., 1997, Preliminary geologic map of the Strawberry Quadrangle, Yavapai, Gila, and Coconino Counties, Arizona: U.S. Geological Survey Open-File Report, OF 94-0265, 1 sheet.

Weisman, M.C., 1984, Geology of the Pine and northern Buckhead Mesa quadrangles, Mogollon Rim region, central Arizona: Flagstaff, Northern Arizona University, master's thesis, $126 \mathrm{p}$.

Weisman, M.C., and Weir, G.W., 1990, Geologic map of the Pine 7.5' Quadrangle, Coconino and Gila Counties, Arizona: U.S. Geological Survey Miscellaneous Field Studies Map, MF-2123, 1 sheet.
Weitzman, Morley, 2002, Geology and hydrology of the Payson-Strawberry—Diamond Rim area, Gila and Coconino counties, central Arizona: Tucson, Arizona Geological Survey Contributed Report CR-02-B, 17 p.

Wilson, E.D., Moore, R.T., Peirce, H.W., 1959, Geologic map of Gila County, Arizona: Tucson, Arizona Bureau of Mines, scale 1:375,000.

Wrucke, C.T., and Conway, C.M., 1987, Geologic map of the Mazatzal wilderness and contiguous roadless area, Gila, Maricopa, and Yavapai Counties, Arizona: U.S. Geological Survey Open-File Report, p. 22. 
This page left blank intentionally. 
This page left blank intentionally. 
Printed on recycled paper 